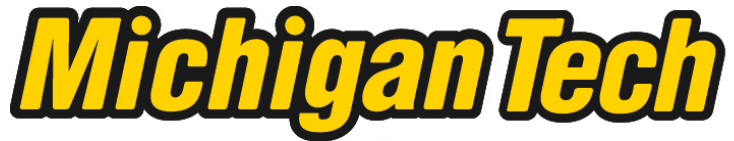 \\ Michigan Technological University Create the Future Digital Commons @ Michigan Tech
}

Identifying indicators of sustainable development using the global sustainability quadrant approach

Andres B. Tarte

Michigan Technological University

Follow this and additional works at: https://digitalcommons.mtu.edu/etds

Part of the Civil and Environmental Engineering Commons

Copyright 2009 Andres B. Tarte

\section{Recommended Citation}

Tarte, Andres B., "Identifying indicators of sustainable development using the global sustainability quadrant approach ", Master's Thesis, Michigan Technological University, 2009.

https://doi.org/10.37099/mtu.dc.etds/275

Follow this and additional works at: https://digitalcommons.mtu.edu/etds

3 Part of the Civil and Environmental Engineering Commons 
IDENTIFYING INDICATORS OF SUSTAINABLE DEVELOPMENT USING

THE GLOBAL SUSTAINABILITY QUADRANT APPROACH

By

ANDRES B. TARTE

\begin{abstract}
A THESIS
Submitted in partial fulfillment of the requirements

for the degree of

MASTER OF SCIENCE IN ENVIRONMENTAL ENGINEERING
\end{abstract}

MICHIGAN TECHNOLOGICAL UNIVERSITY

2009

Copyright (C) Andrés B. Tarté 2009 
This thesis, "Identifying Indicators of Sustainable Development Using the Global Sustainability Quadrant Approach," is hereby approved in partial fulfillment of the requirements for the Degree of MASTER OF SCIENCE IN ENVIRONMENTAL ENGINEERING.

DEPARTMENT:

Civil and Environmental Engineering

Signatures:

Thesis Advisor:

Dr. Kurtis G. Paterson

Thesis Co-advisor:

Dr. Qiong Zhang

Department Chair:

Dr. William M. Bulleit

Date: 


\title{
Identifying Indicators of Sustainable Development Using the Global Sustainability Quadrant Approach
}

\begin{abstract}
Advances in information technology and global data availability have opened the door for assessments of sustainable development at a truly macro scale. It is now fairly easy to conduct a study of sustainability using the entire planet as the unit of analysis; this is precisely what this work set out to accomplish.
\end{abstract}

The study began by examining some of the best known composite indicator frameworks developed to measure sustainability at the country level today. Most of these were found to value human development factors and a clean local environment, but to gravely overlook consumption of (remote) resources in relation to nature's capacity to renew them, a basic requirement for a sustainable state.

Thus, a new measuring standard is proposed, based on the Global Sustainability Quadrant approach $^{1}$. In a two-dimensional plot of nations' Human Development Index (HDI) vs. their Ecological Footprint (EF) per capita, the Sustainability Quadrant is defined by the area where both dimensions satisfy the minimum conditions of sustainable development: an HDI score above 0.8 (considered 'high' human development), and an EF below the fair Earth-share of 2.063 global hectares per person.

After developing methods to identify those countries that are closest to the Quadrant in the present-day and, most importantly, those that are moving towards it over time, the study tackled the question: what indicators of performance set these countries apart $?^{2}$ To answer this, an analysis of raw data, covering a wide array of environmental, social, economic, and governance performance metrics, was undertaken. The analysis used country rank lists for each individual metric and compared them, using the Pearson Product Moment Correlation function, to the rank lists generated by the proximity/movement relative to the Quadrant measuring methods.

The analysis yielded a list of metrics which are, with a high degree of statistical significance, associated with proximity to - and movement towards - the Quadrant; most notably:

\footnotetext{
${ }^{1}$ The "Sustainable Development Quadrant" was introduced as such by Boutaud A., 2002, and has been used since in a couple of joint publications by the World Wildlife Fund (WWF) and the Global Footprint Network. The term 'Global' has been added here to emphasize that this is a standard set for a sustainable global citizen, meaning that sustainability is assessed in terms of the fair Earth-share of resources, and not in terms of any particular country's amount of resources.

2 The countries identified by this approach are not the ones that usually top the "Most Developed" lists available in the literature.
} 
- Favorable for sustainable development: use of contraception, high life expectancy, high literacy rate, and urbanization.

- Unfavorable for sustainable development: high GDP per capita, high language diversity, high energy consumption, and high meat consumption.

- A momentary gain, but a burden in the long-run: high carbon footprint and debt.

These results could serve as a solid stepping stone for the development of more reliable composite index frameworks for assessing countries' sustainability.

Keywords: Sustainable development, sustainability indicators, global sustainability, sustainability quadrant, Ecological Footprint, Human Development Index. 


\section{Acknowledgements}

At Michigan Technological University (MTU):

Kurt Paterson

Qiong Zhang

Hugh Gorman

Neil Hutzler

Debra Charlesworth

Nancy Byers Sprague

Heidi Oschner

Rashelle Sandell

Kimberly Besonen

The faculty, staff, and students of the Department of Civil and Environmental Engineering

At the International Center for Sustainable Development (CIDES) in Panama:

Rodrigo Tarté

Russ Mullen

Benjamín Name

At the Global Footprint Network:

Anders Reed

Maxine McMinn

The Fulbright Scholarship Program - U.S. Department of State

Thank you all. 


\section{Table of Contents}

Abstract iii

Acknowledgements $\quad v$

Table of Contents $\quad$ vi

Table of Figures $\quad$ ix

Table of Tables $\quad$ xi

1. Introduction 1

2. Review of Composite Sustainability Indicator Frameworks 2

2.1. Introduction to Composite Indicator Frameworks 2

2.2. Composite Indicator Frameworks Included in the Review 2

2.3. Synthesis of Indicator Categories Considered by the Reviewed Frameworks 3

2.4. Comparing the Distinct Indicator Frameworks 6

2.5. Conclusion 18

3. What Should Sustainable Development Indicators Indicate? 19

3.1. What is Sustainable Development? 19

3.1.1. Classic Concepts of Sustainable Development 19

3.1.2. A Basic Equation for Sustainable Development 20

3.2. The Sustainability Quadrant Approach 21

3.2.1. The Human Development Index 21

3.2.2. The Ecological Footprint 22

3.2.3. The Global Sustainability Quadrant 24

3.2.4. Limitations of the Approach 26

\begin{tabular}{ll} 
3.3. & Research Objective \\
\hline
\end{tabular}

4. Methodology 28

4.1. Transforming the Ecological Footprint Into an Index 28

4.2. Present-Day Distance From the Quadrant 32

4.2.1. Calculating Present-day Distance From the Quadrant 32

4.2.2. Present-day Distance Country Rank List 34

4.2.3. Comparing the Present-day Distance From Quadrant Approach with other Composite Sustainability Indicator Approaches 42

vi 
4.2.4. Limitations of the Present-day Distance From Quadrant the Approach

4.3. Historical Movement Towards the Quadrant 44

4.3.1. Calculating Movement Towards the Quadrant 44

4.3.2. Limitations of the Movement Towards the Quadrant Approach 45

4.3.3. Historical Movement Towards the Quadrant Country Rank Lists 46

4.3.3.1. Long-term 46

4.3.3.2. Medium-term 52

$\begin{array}{lll}\text { 4.3.3.3. } & \text { Short-term } & 58\end{array}$

4.4. Analysis using Rank Lists and the Pearson Moment Correlation Function 65

4.4.1. Creating Country Rank Lists for the Metrics to be Tested 65

4.4.2. Finding Correlations Using Pearson's R 65

4.4.3. Determining Statistical Significance for Pearson's R 67

4.5. Description of Data Sources $\quad 69$

4.5.1. Present-day Distance From the Quadrant - Metrics Tested 69

4.5.2. Historical Movement Towards the Quadrant - Metrics Tested 81

5. Results of the Analysis 90

5.1. Metric Correlations with Highest Statistical Significance $\quad 90$

5.1.1. Present-Day Correlations with the Highest Statistical Significance 90

5.1.2. Long-Term Correlations with the Highest Statistical Significance 97

5.1.3. Medium-Term Correlations with the Highest Statistical Significance 101

5.1.4. Short-Term Correlations with the Highest Statistical Significance 101

5.2. Metrics with Statistical Significance in Multiple Periods 108

5.3. Other Metrics Worth Mentioning 130

5.3.1. The Water Footprint 130

5.3.2. Ethnic, Language, and Religious Fractionalization 130

5.3.3. Biodiversity and Forest Cover 131

5.3.4. Energy 132

5.3.5. Urbanization 132

6. Conclusions 133

$\begin{array}{lll}\text { 7. Possibilities for Further Research } & 137\end{array}$ 
8.

Appendix A: Overview of Composite Sustainability Indicator Frameworks Reviewed

Appendix B: Original Sources for Metrics Taken from the Earth Trends Portal

Appendix C: Complete List of Statistically Significant Metrics Found in the Analysis

Appendix D: Definitions and Original Sources for Statistically Significant Metrics Found in the Analysis

Appendix E: A Brief History of the Concentric Circles Approach to Sustainable Development 231

Appendix F: Table of Critical Values for Pearson's R 


\section{Table of Figures}

Figure 3-1: The Dimensions of Sustainable Development 20

Figure 3-2: Basic Links between the Dimensions of Sustainable Development 20

Figure 3-3: World Ecological Footprint and Biological Capacity per Capita (1980-2005) 23

Figure 3-4: The Global Sustainability Quadrant (2005) 25

Figure 4-1: Transforming EF into and Index using Goalpost Values 29

Figure 4-2: The Global Sustainability Quadrant using the EF Indexed Score (2005) 31

Figure 4-3: Calculating Present-Day (2005) Distance from the Sustainability Quadrant 33

Figure 4-4: Present-day (2005) Distance From the Quadrant - Top Performers 39

Figure 4-5: Present-day (2005) distance From the Quadrant - Bottom Performers 40

Figure 4-6: Present-day (2005) Distance from Quadrant World Map (quintiles) 41

Figure 4-7: Calculating Movement Towards the Quadrant 45

Figure 4-8: Long-term (1980-2005) Movement Towards the Quadrant - Top 5 Performers 49

Figure 4-9: Long-term (1980-2005) Movement Towards the Quadrant - Bottom 5 Performers 50

Figure 4-10: Long-term (1980-2005) Movement Towards the Quadrant World Map (quintiles) 51

Figure 4-11: Medium-term (1990-2005) Movement Towards the Quadrant - Top 5

Performers $\quad 55$

Figure 4-12: Medium-term (1990-2005) Movement Towards the Quadrant - Bottom 5

Performers 56

Figure 4-13: Medium-term (1990-2005) Movement Towards the Quadrant World Map (quintiles)

Figure 4-14: Short-term (2000-2005) Movement Towards the Quadrant - Top 5 Performers 62

Figure 4-15: Short-term (2000-2005) Movement Towards the Quadrant - Bottom 5

Performers 63

Figure 4-16: Short-term (2000-2005) Movement Towards the Quadrant World Map (quintiles) 64

Figure 4-17: Sample Analysis Using Pearson Moment Correlation and Rank Lists 67

Figure 5-1: Contraceptive Prevalence Rate (CPR) vs. Present-day Distance From the Quadrant

(country ranks) 95

Figure 5-2: Contraceptive Prevalence Rate (CPR) - Present-day Distance From the Quadrant 96

Figure 5-3: Meat Consumption per capita - Long-term Movement (1980 to 2005) 99

Figure 5-4: Meat Consumption per capita - Top Movers, Long-term (1980 to 2005) 100 
Figure A-1: Components and Weighting Factors of the EPI

Figure E-1: The Dimensions of Sustainable Development - Classic Illustration Approach 231

Figure E-2: The Dimensions of Sustainable Development - the Concentric Circles Approach 232

Figure E-3: The Concentric Circles Approach Taken from Lozano, 2006232

Figure E-4: The Concentric Circles Approach Taken from Mebratu, 1996

Figure E-5: The Concentric Circles Approach Taken from Hart, 1998

Figure E-6: The Concentric Circles Approach Taken from Meter, 1999 


\section{Table of Tables}

Table 2-1: Composite Indicator Frameworks Reviewed 3

Table 2-2: Hierarchical Indicator Structure $\quad 4$

Table 2-3: Sustainability Indicator Subsystems and Elements Considered by the Reviewed Frameworks 4

Table 2-4: Composite Indicator Frameworks Reviewed - Country Ranks Worldwide 7

Table 2-5: Correlation Matrix of Selected Composite Indicator Frameworks 17

Table 3-1: Calculation of the Human Development Index 22

Table 4-1: Sample 2005 Ecological Footprint Values Transformed into an Index Score 31

Table 4-2: Present-day (2005) Distance From the Quadrant - Country Rank List 34

Table 4-3: Updated Indicator Correlation Matrix (Includes Distance From the Quadrant Approach) 43

Table 4-4: Long-term (1980 to 2005) Movement Towards the Quadrant - Country Rank List 46

Table 4-5: Medium-term (1990 to 2005) Movement Towards the Quadrant - Country Rank List 52

Table 4-6: Short-term (2000 to 2005) Movement Towards the Quadrant - Country Rank List 58

Table 4-7: Sources used in the SEDAC Compendium of 70

Environmental Sustainability Indicator Collections 70

Table 4-8: List of Present-Day Metrics Sourced from the Earth Trends Web Portal 71

Table 4-9: List of Metrics Sourced from the UNDP's Human Development Reports 77

Table 4-10: List of Individual Components of the 2005 Ecological Footprint 80

Table 4-11: List of Individual Components of the Water Footprint (years 1997-2001) 81

Table 4-12: Complete List of Metrics Analyzed for Historical Movement Sourced from the 82 Earth Trends Portal $\quad 82$

Table 4-13: List of Ecological Footprint Components Analyzed for Historical Movement 89

Table 5-1: Present-Day Correlations with the Highest Statistical Significance, $\mathrm{P}\left(\mathrm{H}_{0}\right)=<0.001$, and $R>|0.5| \quad 92$

Table 5-2: Long-Term (1980 to 2005) Correlations with the Highest Statistical Significance, $\mathrm{P}\left(\mathrm{H}_{0}\right)=<0.001 \quad 97$

Table 5-3: Medium-Term (1990 to 2005) Correlations with the Highest Statistical

Significance, $\mathrm{P}\left(\mathrm{H}_{0}\right)=<0.001$ 
Table 5-4: Short-Term (2000 to 2005) Correlations with the Highest Statistical Significance, $\mathrm{P}\left(\mathrm{H}_{0}\right)=<0.001 \quad 102$

Table 5-5: Metrics with Statistical Significance on more than One Term 109

Table 5-6: Fractionalization - Present-day Distance from Quadrant Correlation Results 130

Table 5-7: NBI - Present-day Distance from Quadrant Correlation Results 131

Table 5-8: Forest Cover - Present-day Distance from Quadrant Correlation Results 132

Table 5-9: Urbanization- Present-day Distance from Quadrant Correlation Results 132

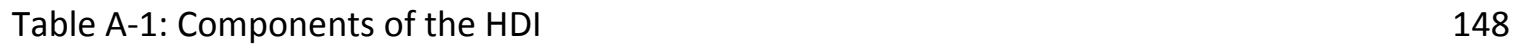

Table A-2: Components of the ESI 151

Table A-3: Components of the EVI 155

Table A-4: Components of the SDI 157

Table A-5: Components of the QLI 163

Table B-1: Original Sources for Metrics Taken from the Earth Trends Portal 164

Table C-1: Complete List of Statistically Significant Metrics Found in the Analysis 189

Table D-1: Definitions and Sources for Statistically Significant Metrics Found in the Analysis 200

Table F-1: Table of Critical Values for Pearson's R 235 


\section{Introduction}

This work started as an attempt to develop a set of relevant indicators to assess sustainable development in Panama. However, it quickly evolved and its scope was broadened to include the entire planet. This happened for two specific reasons:

- The lack of clear standards for what constitutes a nation that is developing itself in a sustainable fashion.

- The realization that advances in information technology and global data availability have opened the door for assessments of sustainable development at a truly macro scale. It is now fairly easy to conduct a study of sustainability using the entire planet as the unit of analysis.

After examining some of the approaches - composite indicator frameworks - used to assess sustainable development at the country level (Chapter 2), a new measuring standard was proposed, based on the Global Sustainability Quadrant approach (described in detail in Chapter 3), which combines Ecological Footprint and Human Development Index measures. A compilation and analysis of global data, covering a wide array of environmental, social, economic, and governance performance metrics ${ }^{3}$, was undertaken with the purpose of finding those metrics associated with proximity to - and movement towards - the Sustainability Quadrant (Chapter 4). The results (Chapter 5 ) could serve as a solid stepping stone for the development of more reliable composite index frameworks for assessing countries' sustainability.

\footnotetext{
${ }^{3}$ The terms 'indicators' and 'metrics' are generally used to refer to qualitative and quantitative measures of sustainability, respectively (Jeon, et al., 2005). A metric can serve as an indicator when its validity has been proven.
} 


\section{Review of Composite Sustainability Indicator Frameworks}

With the purpose of finding adequate measures of sustainable development at the country level, a review and brief comparative analysis of widely used composite indicator frameworks is conducted in this Chapter.

\subsection{Introduction to Composite Indicator Frameworks}

The construction of adequate and reliable indicators for sustainable development is a process that is constantly evolving. Countless different frameworks designed to measure sustainability have been published in the literature. Not surprisingly, many of these are subject to heavy criticism. Frey and Yaneske observe that "the fragmentation of a complex system into manageable chunks seems to have led to the loss of connections between individual characteristics and problems" (Frey, et al., 2007). Referring in concrete to the UNEP's Environmental Indicators for Central Asia, they continue stating that "each of the indicators is assessed separately, and no mechanism is made available to establish the interdependencies between social, economic, and environmental change trends."

The creation of composite indicators is an attempt to overcome such fragmentation. Composite indicator frameworks integrate indicators from several different subsystems or categories to arrive at a comprehensive score, index, or standardized unit. "While common frameworks still do not automatically lead to common measures and common measures may not lead to coordinated action, they are important components of an enabling environment and governance mechanism that can result in effective action for sustainability" (Pintér et al., 2005).

Another advantage of these composite indicator frameworks is that, because they deliver a comprehensive final score, they allow for comparisons in time (to assess progress), as well as across borders.

\subsection{Composite Indicator Frameworks Included in the Review}

The frameworks selected for this review are (1) widely referenced in the literature, and (2) have published their results for countries worldwide. A total of 10 frameworks were reviewed, they are listed in Table 2-1. 
Table 2-1: Composite Indicator Frameworks Reviewed

Source: Compiled by the author.

\begin{tabular}{|r|l|}
\hline \multicolumn{2}{|c|}{ Composite Indicator Framework } \\
\hline 1 & Ecological Footprint (EF) \\
\hline 2 & Human Development Index (HDI) \\
\hline 3 & Environmental Performance Index (EPI) \\
\hline 4 & Environmental Sustainability Index (ESI) \\
\hline 5 & Sustainable Society Index (SSI) \\
\hline 6 & Environmental Vulnerability Index (EVI) \\
\hline 7 & Sustainable Development Index (SDI) \\
\hline 8 & Prescott-Allen's Wellbeing Index (WI) \\
\hline 9 & Happy Planet Index (HPI) \\
\hline 10 & Quality of Life Index (QOL) \\
\hline
\end{tabular}

See Appendix A for an overview of these 10 indicator frameworks, including the entities that have developed and/or maintain them, calculation methodologies, and lists of the specific indicator categories they consider in their estimates.

It should be noted that the Human Development Index (HDI) and the Quality of Life Index (QOL) frameworks do not incorporate environmental considerations directly in their calculations. Nevertheless, they are included here because they are commonly used (especially the HDI) to assess development in general. ${ }^{4}$ Furthermore, the HDI (along with the Ecological Footprint) plays an essential part in the conception of the Global Sustainability Quadrant, which will be introduced in Chapter 3.

\subsection{Synthesis of Indicator Categories Considered by the Reviewed Frameworks}

After detailed examination of the specific indicators used in all 10 reviewed frameworks, a compilation was made of the indicator categories covered by such. The approach used for this compilation follows Prescott-Allen's (2006) proposed structure of subsystems and elements, summed up in Table 2-2. The compilation itself appears in Table 2-3.

\footnotetext{
${ }^{4}$ The lack of the adjective 'sustainable' should not exclude an indicator framework from a discussion of sustainable development; after all, if it cannot be sustained through time, it probably should not be called 'development'.
} 
Table 2-2: Hierarchical Indicator Structure

Source: Adapted from Prescott-Allen, 2006.

\begin{tabular}{|c|c|c|}
\hline Level & \multicolumn{2}{|c|}{ Examples } \\
\hline System & \multicolumn{2}{|c|}{ country or other geo-unit } \\
\hline Subsystem & $\begin{array}{l}\text { human } \\
\text { subsystem }\end{array}$ & $\begin{array}{l}\text { ecological } \\
\text { subsystem }\end{array}$ \\
\hline Element group & $\begin{array}{c}\text { knowledge \& } \\
\text { culture }\end{array}$ & $\begin{array}{l}\text { environmental } \\
\text { quality }\end{array}$ \\
\hline Element & knowledge & air \& atmosphere \\
\hline $\begin{array}{l}\text { Subelement } \\
\text { (indicator group) }\end{array}$ & education & local air quality \\
\hline Indicator & $\begin{array}{l}\text { educational } \\
\text { attainment }\end{array}$ & $\begin{array}{l}\text { ambient daily } \\
\text { concentration of } \\
\text { particulates }\end{array}$ \\
\hline
\end{tabular}

Table 2-3: Sustainability Indicator Subsystems and Elements Considered by the Reviewed Frameworks

Source: Compiled and classified by the author.

\begin{tabular}{|c|c|}
\hline Subsystem & Element \\
\hline \multirow{7}{*}{ A. Ecosystems and Natural Resources } & Atmospheric balance \\
\hline & Hydrologic balance \\
\hline & Soil nutrient balance and arable land \\
\hline & Biodiversity \\
\hline & Forests and biomass \\
\hline & Oceans, seas, and coasts \\
\hline & Rivers, streams, and lakes \\
\hline \multirow{14}{*}{ B. Human and Societal Wellbeing } & Population growth \\
\hline & Food security, nutrition \\
\hline & Water quality and availability \\
\hline & Overall health - access to health services \\
\hline & Shelter \\
\hline & Clean air \\
\hline & Security \\
\hline & Income \\
\hline & Transportation \\
\hline & Access to communications \\
\hline & Social equality (includes gender) \\
\hline & Family planning, access to reproductive health \\
\hline & Knowledge, education \\
\hline & Recreation opportunities, leisure time \\
\hline
\end{tabular}


Table 2-3 (continued)

\begin{tabular}{|c|c|}
\hline Subsystem & Element \\
\hline & Cultural diversity \\
\hline \multirow{12}{*}{ C. Economy } & Internalization of environmental and social costs \\
\hline & Cultivated systems \\
\hline & Fishing (wild) \\
\hline & Energy \\
\hline & Eco-Efficient technology in industry \\
\hline & Forestry \\
\hline & Tourism \\
\hline & Mining \\
\hline & Waste management \\
\hline & Payment for ecosystem services \\
\hline & Transport \\
\hline & Housing, buildings, and infrastructure \\
\hline \multirow{16}{*}{ D. Governance/Policies } & Corruption \\
\hline & Macroeconomic performance \\
\hline & Public finance (debt) \\
\hline & Social investment / aid \\
\hline & Freedom \\
\hline & Justice \\
\hline & $\begin{array}{l}\text { Civil society participation, awareness, and } \\
\text { demands }\end{array}$ \\
\hline & Preparedness and response to natural hazards \\
\hline & Integrated Land-use planning \\
\hline & Urban planning initiatives \\
\hline & Fair trade policies \\
\hline & Private sector commitment to good stewardship \\
\hline & Sustainability integrated into national policies \\
\hline & Integrated policy management \\
\hline & Integrated knowledge management initiatives \\
\hline & Participation in international collaboration \\
\hline
\end{tabular}




\subsection{Comparing the Distinct Indicator Frameworks}

A comparison of the composite indicator frameworks serves two purposes, (1) to assess individual countries' relative performance, and (2) to evaluate the frameworks themselves. Country scores for the 10 frameworks were compiled for 142 countries worldwide. ${ }^{5}$ For each framework, countries were ranked according to their score (from best to worst). Table 2-4 lists these countries alphabetically and their corresponding scores.

\footnotetext{
${ }^{5} 142$ is the minimum number of countries shared by the HDI and the EF analyses - the components of the Global Sustainability Quadrant, which will be introduced in Chapter 3.
} 
Table 2-4: Composite Indicator Frameworks Reviewed - Country Ranks Worldwide

Note: An additional framework - the Eco (Deficit) or Reserve - is included in the table; it is a variation of the Ecological Footprint per capita approach, where the country's per capita footprint is subtracted from the country's total Biocapacity per capita to determine whether countries are living within their own limits. See Section 3.2.2. for more details about Ecological Footprint and Biocapacity. ${ }^{6}$

Source: Compiled by the author. See Appendix A for the Composite Indicator Frameworks' sources.

\begin{tabular}{|c|c|c|c|c|c|c|c|c|c|c|c|}
\hline $\begin{array}{l}\text { Composite Indicator } \\
\text { Framework }\end{array}$ & $\begin{array}{l}\text { Eco. } \\
\text { Foot- } \\
\text { print } \\
\text { per } \\
\text { capita } \\
\text { (EF) }\end{array}$ & $\begin{array}{l}\text { Human } \\
\text { Dev. } \\
\text { Index } \\
\text { (HDI) }\end{array}$ & $\begin{array}{l}\text { Env. } \\
\text { Perfor- } \\
\text { mance } \\
\text { Index } \\
\text { (EPI) }\end{array}$ & $\begin{array}{l}\text { Env. } \\
\text { Sust. } \\
\text { Index } \\
\text { (ESI) }\end{array}$ & $\begin{array}{l}\text { Sust. } \\
\text { Society } \\
\text { Index } \\
\text { (SSI) }\end{array}$ & $\begin{array}{c}\text { Env. } \\
\text { Vulner- } \\
\text { ability } \\
\text { Index } \\
\text { (EVI) }\end{array}$ & $\begin{array}{l}\text { Sust. } \\
\text { Dev. } \\
\text { Index } \\
\text { (SDI) }\end{array}$ & $\begin{array}{c}\text { Well- } \\
\text { being } \\
\text { Index } \\
\text { (WI) }\end{array}$ & $\begin{array}{l}\text { Happy } \\
\text { Planet } \\
\text { Index } \\
\text { (HPI) }\end{array}$ & $\begin{array}{l}\text { Quality } \\
\text { of Life } \\
\text { Index } \\
\text { (QOL) }\end{array}$ & $\begin{array}{c}\text { Eco. } \\
\text { (Deficit) } \\
\text { or } \\
\text { Reserve } \\
\text { (global } \\
\text { ha. per } \\
\text { capita) }\end{array}$ \\
\hline Latest measurement & 2005 & 2006 & 2008 & 2005 & 2008 & 2005 & 2002 & 2001 & 2006 & 2005 & 2005 \\
\hline Number of countries & 142 & 142 & 138 & 137 & 137 & 142 & 139 & 142 & 142 & 99 & 142 \\
\hline Country & rank & rank & rank & rank & rank & rank & rank & rank & rank & rank & rank \\
\hline Albania & 79 & 52 & 26 & 22 & 16 & 103 & 39 & 63 & 63 & 68 & 106 \\
\hline Algeria & 58 & 75 & 62 & 93 & 114 & 54 & 87 & 101 & 48 & 71 & 100 \\
\hline Angola & 19 & 122 & 138 & 119 & 125 & 13 & 139 & 94 & 122 &.. & 27 \\
\hline Argentina & 85 & 37 & 36 & 7 & 108 & 66 & 32 & 41 & 27 & 33 & 11 \\
\hline Armenia & 49 & 65 & 58 & 42 & 26 & 23 & 70 & 28 & 99 & 74 & 95 \\
\hline Australia & 139 & 3 & 43 & 11 & 61 & 19 & 13 & 13 & 107 & 5 & 7 \\
\hline Austria & 124 & 12 & 6 & 8 & 5 & 129 & 6 & 4 & 38 & 17 & 121 \\
\hline Azerbaijan & 77 & 73 & 76 & 95 & 117 & 119 & 77 & 110 & 75 & 75 & 108 \\
\hline Bangladesh & 4 & 113 & 118 & 110 & 19 & 109 & 103 & 102 & 25 & 67 & 76 \\
\hline Belarus & 110 & 50 & 40 & 44 & 38 & 20 & 41 & 39 & 132 & 89 & 85 \\
\hline Belgium & 127 & 15 & 53 & 109 & 62 & 138 & 11 & 21 & 51 & 19 & 135 \\
\hline
\end{tabular}

\footnotetext{
${ }^{6}$ The Ecological Footprint measures human consumption and puts it in terms of 'biologically productive land area' required to produce what we consume and assimilate our wastes. Biocapacity simply indicates the amount of biologically productive land area available within a country. They are both expressed in global hectares (gha.). When a country's Ecological Footprint is greater than its Biocapacity, it is incurring in an ecological deficit, meaning that it is importing Biocapacity (through imported products) and exporting its Footprint.
} 
Table 2-4 (continued)

\begin{tabular}{|c|c|c|c|c|c|c|c|c|c|c|c|}
\hline $\begin{array}{l}\text { Composite Indicator } \\
\text { Framework }\end{array}$ & $\begin{array}{l}\text { Eco. } \\
\text { Foot- } \\
\text { print } \\
\text { per } \\
\text { capita } \\
\text { (EF) }\end{array}$ & $\begin{array}{l}\text { Human } \\
\text { Dev. } \\
\text { Index } \\
\text { (HDI) }\end{array}$ & $\begin{array}{l}\text { Env. } \\
\text { Perfor- } \\
\text { mance } \\
\text { Index } \\
\text { (EPI) }\end{array}$ & $\begin{array}{l}\text { Env. } \\
\text { Sust. } \\
\text { Index } \\
\text { (ESI) }\end{array}$ & $\begin{array}{l}\text { Sust. } \\
\text { Society } \\
\text { Index } \\
\text { (SSI) }\end{array}$ & $\begin{array}{l}\text { Env. } \\
\text { Vulner- } \\
\text { ability } \\
\text { Index } \\
\text { (EVI) }\end{array}$ & $\begin{array}{l}\text { Sust. } \\
\text { Dev. } \\
\text { Index } \\
\text { (SDI) }\end{array}$ & $\begin{array}{c}\text { Well- } \\
\text { being } \\
\text { Index } \\
\text { (WI) }\end{array}$ & $\begin{array}{l}\text { Happy } \\
\text { Planet } \\
\text { Index } \\
\text { (HPI) } \\
\end{array}$ & $\begin{array}{l}\text { Quality } \\
\text { of Life } \\
\text { Index } \\
\text { (QOL) }\end{array}$ & $\begin{array}{l}\text { Eco. } \\
\text { (Deficit) } \\
\text { or } \\
\text { Reserve } \\
\text { (global } \\
\text { ha. per } \\
\text { capita) }\end{array}$ \\
\hline Latest measurement & 2005 & 2006 & 2008 & 2005 & 2008 & 2005 & 2002 & 2001 & 2006 & 2005 & 2005 \\
\hline Number of countries & 142 & 142 & 138 & 137 & 137 & 142 & 139 & 142 & 142 & 99 & 142 \\
\hline Country & rank & rank & rank & rank & rank & rank & rank & rank & rank & rank & rank \\
\hline Benin & 25 & 125 & 120 & 84 & 29 & 57 & 104 & 32 & 79 &.. & 45 \\
\hline Bhutan & 24 & 99 & .. & 41 & 52 & 32 & .. & 70 & 9 &.. & 42 \\
\hline Bolivia & 74 & 83 & 103 & 17 & 94 & 28 & 74 & 36 & 45 & 72 & 2 \\
\hline Bosnia Herzegovina & 93 & 58 & 45 & 59 & 44 & 82 & 73 & 115 & 73 & 83 & 104 \\
\hline Botswana & 106 & 95 & 92 & 32 & 115 & 1 & 82 & 26 & 133 & 93 & 16 \\
\hline Brazil & 82 & 53 & 33 & 9 & 41 & 62 & 44 & 71 & 40 & 32 & 14 \\
\hline Bulgaria & 90 & 44 & 52 & 68 & 56 & 98 & 40 & 50 & 112 & 49 & 59 \\
\hline Burkina Faso & 69 & 137 & 134 & 94 & 58 & 15 & 117 & 95 & 115 & ... & 84 \\
\hline Burundi & 14 & 136 & 125 & 125 & 119 & 68 & 138 & 123 & 141 & .. & 69 \\
\hline Cambodia & 22 & 103 & 128 & 65 & 39 & 43 & 133 & 85 & 62 & .. & 64 \\
\hline Cameroon & 42 & 116 & 107 & 48 & 70 & 16 & 105 & 77 & 110 & ... & 30 \\
\hline Canada & 137 & 2 & 11 & 5 & 36 & 30 & 3 & 5 & 80 & 12 & 4 \\
\hline Central African Rep & 54 & 141 & 121 & 23 & 89 & 2 & 119 & 67 & 130 & ... & 6 \\
\hline Chad & 61 & 134 & 133 & 99 & 107 & 11 & 135 & 106 & 134 &.. & 34 \\
\hline Chile & 94 & 31 & 28 & 40 & 20 & 67 & 38 & 59 & 29 & 25 & 36 \\
\hline
\end{tabular}


Table 2-4 (continued)

\begin{tabular}{|c|c|c|c|c|c|c|c|c|c|c|c|}
\hline $\begin{array}{c}\text { Composite Indicator } \\
\text { Framework }\end{array}$ & $\begin{array}{c}\text { Eco. } \\
\text { Foot- } \\
\text { print } \\
\text { per } \\
\text { capita } \\
\text { (EF) }\end{array}$ & $\begin{array}{c}\text { Human } \\
\text { Dev. } \\
\text { Index } \\
\text { (HDI) }\end{array}$ & $\begin{array}{l}\text { Env. } \\
\text { Perfor- } \\
\text { mance } \\
\text { Index } \\
\text { (EPI) }\end{array}$ & $\begin{array}{l}\text { Env. } \\
\text { Sust. } \\
\text { Index } \\
\text { (ESI) } \\
\end{array}$ & $\begin{array}{l}\text { Sust. } \\
\text { Society } \\
\text { Index } \\
\text { (SSI) }\end{array}$ & $\begin{array}{c}\text { Env. } \\
\text { Vulner- } \\
\text { ability } \\
\text { Index } \\
\text { (EVI) }\end{array}$ & $\begin{array}{l}\text { Sust. } \\
\text { Dev. } \\
\text { Index } \\
\text { (SDI) }\end{array}$ & $\begin{array}{c}\text { Well- } \\
\text { being } \\
\text { Index } \\
\text { (WI) }\end{array}$ & $\begin{array}{l}\text { Happy } \\
\text { Planet } \\
\text { Index } \\
\text { (HPI) }\end{array}$ & $\begin{array}{l}\text { Quality } \\
\text { of Life } \\
\text { Index } \\
\text { (QOL) }\end{array}$ & $\begin{array}{c}\text { Eco. } \\
\text { (Deficit) } \\
\text { or } \\
\text { Reserve } \\
\text { (global } \\
\text { ha. per } \\
\text { capita) }\end{array}$ \\
\hline Latest measurement & 2005 & 2006 & 2008 & 2005 & 2008 & 2005 & 2002 & 2001 & 2006 & 2005 & 2005 \\
\hline Number of countries & 142 & 142 & 138 & 137 & 137 & 142 & 139 & 142 & 142 & 99 & 142 \\
\hline Country & rank & rank & rank & rank & rank & rank & rank & rank & rank & rank & rank \\
\hline China & 73 & 72 & 99 & 128 & 71 & 125 & 66 & 130 & 19 & 52 & 111 \\
\hline Colombia & 66 & 62 & 9 & 20 & 53 & 75 & 48 & 60 & 1 & 46 & 28 \\
\hline Congo & 3 & 98 & 87 & 37 & 76 & 12 &.. & 57 & 67 &.. & 3 \\
\hline Congo Dem Rep & 5 & 140 & 132 & 111 & 88 & 69 & 116 & 107 & 140 &.. & 19 \\
\hline Costa Rica & 81 & 40 & 5 & 16 & 10 & 120 & 27 & 37 & 2 & 28 & 86 \\
\hline Cote Divoire & 16 & 130 & 97 & 86 & 84 & 25 & 109 & 86 & 117 &.. & 32 \\
\hline Croatia & 98 & 36 & 19 & 18 & 42 & 110 & 37 & 47 & 55 & 41 & 105 \\
\hline Cuba & 63 & 39 & 38 & 51 & 14 & 102 & 34 & 61 & 4 &.. & 98 \\
\hline Czech Republic & 130 & 28 & 64 & 88 & 66 & 91 & 33 & 22 & 97 & 27 & 126 \\
\hline Denmark & 140 & 11 & 24 & 24 & 13 & 112 & 12 & 9 & 69 & 7 & 125 \\
\hline Dominican Republic & 51 & 69 & 31 & 116 & 85 & 100 & 54 & 42 & 18 & 69 & 97 \\
\hline Ecuador & 78 & 54 & 21 & 49 & 81 & 80 & 71 & 30 & 35 & 44 & 66 \\
\hline Egypt & 59 & 87 & 67 & 112 & 132 & 76 & 91 & 68 & 68 & 70 & 113 \\
\hline El Salvador & 55 & 76 & 61 & 114 & 30 & 113 & 65 & 69 & 6 & 48 & 103 \\
\hline Eritrea & 38 & 128 & 115 &.. &.. & 33 & 140 & 111 & 106 &.. & 40 \\
\hline Estonia & 135 & 33 & 18 & 25 & 73 & 60 & 22 & 40 & 138 & 59 & 22 \\
\hline
\end{tabular}


Table 2-4 (continued)

\begin{tabular}{|c|c|c|c|c|c|c|c|c|c|c|c|}
\hline $\begin{array}{c}\text { Composite Indicator } \\
\text { Framework }\end{array}$ & $\begin{array}{c}\text { Eco. } \\
\text { Foot- } \\
\text { print } \\
\text { per } \\
\text { capita } \\
\text { (EF) }\end{array}$ & $\begin{array}{c}\text { Human } \\
\text { Dev. } \\
\text { Index } \\
\text { (HDI) }\end{array}$ & $\begin{array}{l}\text { Env. } \\
\text { Perfor- } \\
\text { mance } \\
\text { Index } \\
\text { (EPI) }\end{array}$ & $\begin{array}{l}\text { Env. } \\
\text { Sust. } \\
\text { Index } \\
\text { (ESI) } \\
\end{array}$ & $\begin{array}{l}\text { Sust. } \\
\text { Society } \\
\text { Index } \\
\text { (SSI) }\end{array}$ & $\begin{array}{c}\text { Env. } \\
\text { Vulner- } \\
\text { ability } \\
\text { Index } \\
\text { (EVI) }\end{array}$ & $\begin{array}{l}\text { Sust. } \\
\text { Dev. } \\
\text { Index } \\
\text { (SDI) }\end{array}$ & $\begin{array}{c}\text { Well- } \\
\text { being } \\
\text { Index } \\
\text { (WI) }\end{array}$ & $\begin{array}{l}\text { Happy } \\
\text { Planet } \\
\text { Index } \\
\text { (HPI) }\end{array}$ & $\begin{array}{l}\text { Quality } \\
\text { of Life } \\
\text { Index } \\
\text { (QOL) }\end{array}$ & $\begin{array}{c}\text { Eco. } \\
\text { (Deficit) } \\
\text { or } \\
\text { Reserve } \\
\text { (global } \\
\text { ha. per } \\
\text { capita) }\end{array}$ \\
\hline Latest measurement & 2005 & 2006 & 2008 & 2005 & 2008 & 2005 & 2002 & 2001 & 2006 & 2005 & 2005 \\
\hline Number of countries & 142 & 142 & 138 & 137 & 137 & 142 & 139 & 142 & 142 & 99 & 142 \\
\hline Country & rank & rank & rank & rank & rank & rank & rank & rank & rank & rank & rank \\
\hline Ethiopia & 46 & 133 & 116 & 130 & 100 & 37 & 136 & 87 & 111 &.. & 79 \\
\hline Finland & 128 & 10 & 4 & 1 & 4 & 41 & 2 & 2 & 91 & 10 & 9 \\
\hline France & 123 & 8 & 10 & 33 & 15 & 126 & 14 & 18 & 98 & 20 & 119 \\
\hline Gabon & 44 & 80 & 60 & 10 & 21 & 8 & 89 & 48 & 76 &.. & 1 \\
\hline Gambia & 39 & 124 & .. & 69 & 33 & 55 & 111 & 80 & 61 &.. & 62 \\
\hline Georgia & 29 & 70 & 35 & 54 & 7 & 39 & 36 & 51 & 71 & 76 & 43 \\
\hline Germany & 114 & 20 & 12 & 29 & 18 & 122 & 10 & 7 & 54 & 21 & 124 \\
\hline Ghana & 50 & 109 & 81 & 45 & 77 & 58 & 96 & 134 & 44 & 84 & 75 \\
\hline Greece & 133 & 16 & 41 & 66 & 69 & 117 & 23 & 23 & 102 & 18 & 137 \\
\hline Guatemala & 52 & 91 & 65 & 113 & 68 & 108 & 79 & 120 & 7 & 79 & 71 \\
\hline Guinea & 43 & 131 & 129 & 79 & 87 & 34 & 129 & 72 & 92 &.. & 31 \\
\hline Guinea-Bissau & 18 & 135 & 130 & 75 & 91 & 46 & 127 & 78 & 103 &.. & 24 \\
\hline Haiti & 2 & 114 & 112 & 136 & 79 & 111 & 137 & 131 & 57 & 99 & 72 \\
\hline Honduras & 65 & 88 & 69 & 85 & 104 & 49 & 80 & 81 & 5 & 80 & 58 \\
\hline Hungary & 105 & 29 & 22 & 52 & 28 & 128 & 31 & 33 & 90 & 30 & 99 \\
\hline India & 17 & 100 & 113 & 98 & 55 & 136 & 99 & 138 & 39 & 63 & 92 \\
\hline
\end{tabular}


Table 2-4 (continued)

\begin{tabular}{|c|c|c|c|c|c|c|c|c|c|c|c|}
\hline $\begin{array}{c}\text { Composite Indicator } \\
\text { Framework }\end{array}$ & $\begin{array}{l}\text { Eco. } \\
\text { Foot- } \\
\text { print } \\
\text { per } \\
\text { capita } \\
\text { (EF) }\end{array}$ & $\begin{array}{c}\text { Human } \\
\text { Dev. } \\
\text { Index } \\
\text { (HDI) }\end{array}$ & $\begin{array}{l}\text { Env. } \\
\text { Perfor- } \\
\text { mance } \\
\text { Index } \\
\text { (EPI) }\end{array}$ & $\begin{array}{l}\text { Env. } \\
\text { Sust. } \\
\text { Index } \\
\text { (ESI) }\end{array}$ & $\begin{array}{l}\text { Sust. } \\
\text { Society } \\
\text { Index } \\
\text { (SSI) }\end{array}$ & $\begin{array}{c}\text { Env. } \\
\text { Vulner- } \\
\text { ability } \\
\text { Index } \\
\text { (EVI) }\end{array}$ & $\begin{array}{l}\text { Sust. } \\
\text { Dev. } \\
\text { Index } \\
\text { (SDI) } \\
\end{array}$ & $\begin{array}{l}\text { Well- } \\
\text { being } \\
\text { Index } \\
\text { (WI) }\end{array}$ & $\begin{array}{l}\text { Happy } \\
\text { Planet } \\
\text { Index } \\
\text { (HPI) }\end{array}$ & $\begin{array}{l}\text { Quality } \\
\text { of Life } \\
\text { Index } \\
\text { (QOL) }\end{array}$ & $\begin{array}{c}\text { Eco. } \\
\text { (Deficit) } \\
\text { or } \\
\text { Reserve } \\
\text { (global } \\
\text { ha. per } \\
\text { capita) }\end{array}$ \\
\hline Latest measurement & 2005 & 2006 & 2008 & 2005 & 2008 & 2005 & 2002 & 2001 & 2006 & 2005 & 2005 \\
\hline Number of countries & 142 & 142 & 138 & 137 & 137 & 142 & 139 & 142 & 142 & 99 & 142 \\
\hline Country & rank & rank & rank & rank & rank & rank & rank & rank & rank & rank & rank \\
\hline Indonesia & 23 & 82 & 96 & 73 & 95 & 93 & 98 & 64 & 15 & 61 & 46 \\
\hline Iran & 87 & 66 & 63 & 127 & 131 & 89 & 86 & 112 & 43 & 77 & 112 \\
\hline Ireland & 134 & 4 & 32 & 19 & 92 & 96 & 8 & 11 & 81 & 1 & 120 \\
\hline Israel & 121 & 21 & 46 & 60 & 122 & 133 & 29 & 65 & 85 & 31 & 141 \\
\hline Italy & 120 & 17 & 23 & 67 & 51 & 137 & 20 & 19 & 41 & 6 & 132 \\
\hline Jamaica & 32 & 67 & 50 & 105 & 43 & 134 & 43 & 52 & 31 & 55 & 89 \\
\hline Japan & 122 & 7 & 20 & 28 & 24 & 141 & 15 & 16 & 66 & 15 & 138 \\
\hline Jordan & 62 & 68 & 66 & 82 & 130 & 86 & 90 & 124 & 64 & 65 & 115 \\
\hline Kazakhstan & 101 & 55 & 101 & 76 & 116 & 9 & 61 & 96 & 94 & 85 & 41 \\
\hline Kenya & 28 & 110 & 90 & 97 & 46 & 40 & 131 & 116 & 96 &.. & 56 \\
\hline Korea Republic & 108 & 22 & 48 & 118 & 59 & 130 & 50 & 44 & 72 & 24 & 128 \\
\hline Kuwait & 141 & 25 & 104 & 133 & 134 & 99 & 75 & 97 & 124 & 47 & 142 \\
\hline Kyrgyzstan & 33 & 92 & 88 & 78 & 64 & 18 & 56 & 75 & 13 & 92 & 44 \\
\hline Laos & 27 & 101 & 95 & 50 & 60 & 21 & 124 & 82 & 77 &.. & 33 \\
\hline Latvia & 103 & 35 & 8 & 13 & 9 & 44 & 16 & 12 & 127 & 57 & 20 \\
\hline Lebanon & 95 & 60 & 85 & 124 & 111 & 139 & 64 & 88 & 56 &.. & 127 \\
\hline
\end{tabular}


Table 2-4 (continued)

\begin{tabular}{|c|c|c|c|c|c|c|c|c|c|c|c|}
\hline $\begin{array}{c}\text { Composite Indicator } \\
\text { Framework }\end{array}$ & $\begin{array}{l}\text { Eco. } \\
\text { Foot- } \\
\text { print } \\
\text { per } \\
\text { capita } \\
\text { (EF) } \\
\end{array}$ & $\begin{array}{c}\text { Human } \\
\text { Dev. } \\
\text { Index } \\
\text { (HDI) }\end{array}$ & $\begin{array}{l}\text { Env. } \\
\text { Perfor- } \\
\text { mance } \\
\text { Index } \\
\text { (EPI) }\end{array}$ & $\begin{array}{l}\text { Env. } \\
\text { Sust. } \\
\text { Index } \\
\text { (ESI) } \\
\end{array}$ & $\begin{array}{l}\text { Sust. } \\
\text { Society } \\
\text { Index } \\
\text { (SSI) }\end{array}$ & $\begin{array}{c}\text { Env. } \\
\text { Vulner- } \\
\text { ability } \\
\text { Index } \\
\text { (EVI) }\end{array}$ & $\begin{array}{l}\text { Sust. } \\
\text { Dev. } \\
\text { Index } \\
\text { (SDI) }\end{array}$ & $\begin{array}{l}\text { Well- } \\
\text { being } \\
\text { Index } \\
\text { (WI) }\end{array}$ & $\begin{array}{l}\text { Happy } \\
\text { Planet } \\
\text { Index } \\
\text { (HPI) }\end{array}$ & $\begin{array}{l}\text { Quality } \\
\text { of Life } \\
\text { Index } \\
\text { (QOL) }\end{array}$ & $\begin{array}{c}\text { Eco. } \\
\text { (Deficit) } \\
\text { or } \\
\text { Reserve } \\
\text { (global } \\
\text { ha. per } \\
\text { capita) }\end{array}$ \\
\hline Latest measurement & 2005 & 2006 & 2008 & 2005 & 2008 & 2005 & 2002 & 2001 & 2006 & 2005 & 2005 \\
\hline Number of countries & 142 & 142 & 138 & 137 & 137 & 142 & 139 & 142 & 142 & 99 & 142 \\
\hline Country & rank & rank & rank & rank & rank & rank & rank & rank & rank & rank & rank \\
\hline Lesotho & 30 & 120 &.. &. &.. & 61 & 106 & 73 & 136 &.. & 65 \\
\hline Lithuania & 97 & 34 & 15 & 21 & 11 & 90 & 17 & 17 & 116 & 54 & 37 \\
\hline Macedonia & 118 & 51 & 70 & 87 & 67 & 94 & 42 & 55 & 86 & 78 & 129 \\
\hline Madagascar & 31 & 108 & 126 & 62 & 78 & 59 & 121 & 99 & 46 &.. & 23 \\
\hline Malawi & 1 & 126 & 114 & 72 & 45 & 26 & 112 & 66 & 129 &.. & 63 \\
\hline Malaysia & 83 & 49 & 25 & 36 & 118 & 88 & 69 & 79 & 26 & 29 & 52 \\
\hline Mali & 56 & 132 & 135 & 38 & 82 & 10 & 125 & 129 & 108 &.. & 38 \\
\hline Mauritania & 68 & 106 & 136 & 120 & 75 & 17 & 110 & 139 & 93 &.. & 17 \\
\hline Mauritius & 80 & 57 & 54 &.. &.. & 124 & 51 & 34 & 33 &.. & 116 \\
\hline Mexico & 102 & 41 & 44 & 90 & 112 & 83 & 47 & 125 & 23 & 26 & 117 \\
\hline Moldova Republic & 40 & 85 & 82 & 56 & 17 & 97 & 53 & 91 & 113 & 88 & 61 \\
\hline Mongolia & 104 & 84 & 94 & 70 & 103 & 5 & 62 & 31 & 34 &.. & 5 \\
\hline Morocco & 36 & 96 & 78 & 102 & 124 & 92 & 93 & 119 & 24 & 56 & 88 \\
\hline Mozambique & 21 & 139 & 127 & 103 & 49 & 14 & 134 & 126 & 109 &.. & 25 \\
\hline Myanmar & 34 & 102 & 98 & 46 & 98 & 45 & 123 & 113 & 50 &.. & 47 \\
\hline Namibia & 107 & 97 & 83 & 30 & 101 & 3 & 68 & 56 & 87 &.. & 12 \\
\hline
\end{tabular}


Table 2-4 (continued)

\begin{tabular}{|c|c|c|c|c|c|c|c|c|c|c|c|}
\hline $\begin{array}{c}\text { Composite Indicator } \\
\text { Framework }\end{array}$ & $\begin{array}{l}\text { Eco. } \\
\text { Foot- } \\
\text { print } \\
\text { per } \\
\text { capita } \\
\text { (EF) } \\
\end{array}$ & $\begin{array}{c}\text { Human } \\
\text { Dev. } \\
\text { Index } \\
\text { (HDI) }\end{array}$ & $\begin{array}{l}\text { Env. } \\
\text { Perfor- } \\
\text { mance } \\
\text { Index } \\
\text { (EPI) }\end{array}$ & $\begin{array}{l}\text { Env. } \\
\text { Sust. } \\
\text { Index } \\
\text { (ESI) } \\
\end{array}$ & $\begin{array}{l}\text { Sust. } \\
\text { Society } \\
\text { Index } \\
\text { (SSI) }\end{array}$ & $\begin{array}{c}\text { Env. } \\
\text { Vulner- } \\
\text { ability } \\
\text { Index } \\
\text { (EVI) }\end{array}$ & $\begin{array}{l}\text { Sust. } \\
\text { Dev. } \\
\text { Index } \\
\text { (SDI) }\end{array}$ & $\begin{array}{l}\text { Well- } \\
\text { being } \\
\text { Index } \\
\text { (WI) }\end{array}$ & $\begin{array}{l}\text { Happy } \\
\text { Planet } \\
\text { Index } \\
\text { (HPI) }\end{array}$ & $\begin{array}{l}\text { Quality } \\
\text { of Life } \\
\text { Index } \\
\text { (QOL) }\end{array}$ & $\begin{array}{c}\text { Eco. } \\
\text { (Deficit) } \\
\text { or } \\
\text { Reserve } \\
\text { (global } \\
\text { ha. per } \\
\text { capita) }\end{array}$ \\
\hline Latest measurement & 2005 & 2006 & 2008 & 2005 & 2008 & 2005 & 2002 & 2001 & 2006 & 2005 & 2005 \\
\hline Number of countries & 142 & 142 & 138 & 137 & 137 & 142 & 139 & 142 & 142 & 99 & 142 \\
\hline Country & rank & rank & rank & rank & rank & rank & rank & rank & rank & rank & rank \\
\hline Nepal & 8 & 111 & 77 & 83 & 40 & 81 & 101 & 46 & 32 &.. & 82 \\
\hline Netherlands & 115 & 5 & 51 & 39 & 12 & 140 & 9 & 29 & 47 & 14 & 131 \\
\hline New Zealand & 138 & 18 & 7 & 12 & 8 & 72 & 7 & 10 & 65 & 13 & 10 \\
\hline Nicaragua & 70 & 90 & 73 & 63 & 35 & 48 & 94 & 89 & 12 & 66 & 35 \\
\hline Niger & 57 & 138 & 139 & 100 & 109 & 6 & 126 & 121 & 128 &.. & 54 \\
\hline Nigeria & 45 & 119 & 119 & 96 & 74 & 107 & 113 & 108 & 114 & 97 & 81 \\
\hline Norway & 136 & 1 & 3 & 2 & 3 & 50 & 1 & 3 & 84 & 3 & 102 \\
\hline Oman & 119 & 42 & 86 & 81 & 136 & 29 & 84 & 135 & 53 & 58 & 122 \\
\hline Pakistan & 13 & 105 & 117 & 126 & 121 & 131 & 120 & 132 & 82 & 82 & 83 \\
\hline Panama & 96 & 46 & 30 & 26 & 34 & 24 & 35 & 53 & 3 & 39 & 50 \\
\hline Papua New Guinea & 60 & 115 & 102 & 34 & 106 & 31 & 92 & 98 & 49 &.$\cdot$ & 21 \\
\hline Paraguay & 99 & 74 & 59 & 15 & 25 & 38 & 45 & 74 & 30 & 64 & 8 \\
\hline Peru & 53 & 61 & 56 & 14 & 57 & 42 & 67 & 14 & 21 & 45 & 26 \\
\hline Philippines & 15 & 77 & 57 & 121 & 72 & 142 & 83 & 92 & 11 & 36 & 77 \\
\hline Poland & 112 & 30 & 39 & 101 & 93 & 121 & 28 & 43 & 83 & 40 & 118 \\
\hline Portugal & 116 & 27 & 17 & 35 & 22 & 105 & 30 & 24 & 105 & 16 & 130 \\
\hline
\end{tabular}


Table 2-4 (continued)

\begin{tabular}{|c|c|c|c|c|c|c|c|c|c|c|c|}
\hline $\begin{array}{c}\text { Composite Indicator } \\
\text { Framework }\end{array}$ & $\begin{array}{c}\text { Eco. } \\
\text { Foot- } \\
\text { print } \\
\text { per } \\
\text { capita } \\
\text { (EF) }\end{array}$ & $\begin{array}{c}\text { Human } \\
\text { Dev. } \\
\text { Index } \\
\text { (HDI) }\end{array}$ & $\begin{array}{l}\text { Env. } \\
\text { Perfor- } \\
\text { mance } \\
\text { Index } \\
\text { (EPI) }\end{array}$ & $\begin{array}{l}\text { Env. } \\
\text { Sust. } \\
\text { Index } \\
\text { (ESI) } \\
\end{array}$ & $\begin{array}{l}\text { Sust. } \\
\text { Society } \\
\text { Index } \\
\text { (SSI) }\end{array}$ & $\begin{array}{c}\text { Env. } \\
\text { Vulner- } \\
\text { ability } \\
\text { Index } \\
\text { (EVI) }\end{array}$ & $\begin{array}{l}\text { Sust. } \\
\text { Dev. } \\
\text { Index } \\
\text { (SDI) }\end{array}$ & $\begin{array}{c}\text { Well- } \\
\text { being } \\
\text { Index } \\
\text { (WI) }\end{array}$ & $\begin{array}{l}\text { Happy } \\
\text { Planet } \\
\text { Index } \\
\text { (HPI) }\end{array}$ & $\begin{array}{l}\text { Quality } \\
\text { of Life } \\
\text { Index } \\
\text { (QOL) }\end{array}$ & $\begin{array}{c}\text { Eco. } \\
\text { (Deficit) } \\
\text { or } \\
\text { Reserve } \\
\text { (global } \\
\text { ha. per } \\
\text { capita) }\end{array}$ \\
\hline Latest measurement & 2005 & 2006 & 2008 & 2005 & 2008 & 2005 & 2002 & 2001 & 2006 & 2005 & 2005 \\
\hline Number of countries & 142 & 142 & 138 & 137 & 137 & 142 & 139 & 142 & 142 & 99 & 142 \\
\hline Country & rank & rank & rank & rank & rank & rank & rank & rank & rank & rank & rank \\
\hline Romania & 92 & 48 & 79 & 91 & 27 & 106 & 52 & 76 & 89 & 50 & 93 \\
\hline Russia & 109 & 56 & 27 & 31 & 86 & 51 & 60 & 49 & 137 & 94 & 18 \\
\hline Rwanda & 11 & 129 & 124 & 104 & 83 & 77 & 118 & 117 & 119 &.. & 74 \\
\hline Saudi Arabia & 86 & 43 & 74 & 131 & 137 & 52 & 88 & 141 & 60 & 62 & 114 \\
\hline Senegal & 47 & 118 & 108 & 57 & 80 & 56 & 107 & 100 & 74 &.. & 55 \\
\hline Sierra Leone & 10 & 142 & 137 & 117 & 113 & 63 & 130 & 118 & 120 &.. & 53 \\
\hline Singapore & 113 & 24 &.. &.. &.. & 143 & 49 & 35 & 100 & 9 & 136 \\
\hline Slovakia & 100 & 32 & 16 & 47 & 23 & 79 & 24 & 27 & 101 & 37 & 91 \\
\hline Slovenia & 117 & 23 & 14 & 27 & 48 & 127 & 25 & 15 & 52 & 22 & 123 \\
\hline South Africa & 72 & 94 & 91 & 92 & 128 & 101 & 58 & 114 & 123 & 81 & 57 \\
\hline Spain & 132 & 14 & 29 & 74 & 65 & 116 & 18 & 45 & 59 & 8 & 139 \\
\hline Sri Lanka & 26 & 78 & 47 & 77 & 31 & 104 & 81 & 38 & 10 & 35 & 96 \\
\hline Sudan & 84 & 112 & 122 & 135 & 127 & 53 & 108 & 136 & 125 &.. & 48 \\
\hline Swaziland & 7 & 107 & 111 &.. &.. & 22 &.. & 83 & 142 &.. & 39 \\
\hline Sweden & 126 & 6 & 2 & 4 & 1 & 87 & 4 & 1 & 88 & 4 & 15 \\
\hline Switzerland & 125 & 9 & 1 & 6 & 2 & 114 & 5 & 6 & 42 & 2 & 134 \\
\hline
\end{tabular}


Table 2-4 (continued)

\begin{tabular}{|c|c|c|c|c|c|c|c|c|c|c|c|}
\hline $\begin{array}{c}\text { Composite Indicator } \\
\text { Framework }\end{array}$ & $\begin{array}{l}\text { Eco. } \\
\text { Foot- } \\
\text { print } \\
\text { per } \\
\text { capita } \\
\text { (EF) } \\
\end{array}$ & $\begin{array}{c}\text { Human } \\
\text { Dev. } \\
\text { Index } \\
\text { (HDI) }\end{array}$ & $\begin{array}{l}\text { Env. } \\
\text { Perfor- } \\
\text { mance } \\
\text { Index } \\
\text { (EPI) }\end{array}$ & $\begin{array}{l}\text { Env. } \\
\text { Sust. } \\
\text { Index } \\
\text { (ESI) } \\
\end{array}$ & $\begin{array}{l}\text { Sust. } \\
\text { Society } \\
\text { Index } \\
\text { (SSI) }\end{array}$ & $\begin{array}{c}\text { Env. } \\
\text { Vulner- } \\
\text { ability } \\
\text { Index } \\
\text { (EVI) }\end{array}$ & $\begin{array}{l}\text { Sust. } \\
\text { Dev. } \\
\text { Index } \\
\text { (SDI) }\end{array}$ & $\begin{array}{c}\text { Well- } \\
\text { being } \\
\text { Index } \\
\text { (WI) }\end{array}$ & $\begin{array}{l}\text { Happy } \\
\text { Planet } \\
\text { Index } \\
\text { (HPI) }\end{array}$ & $\begin{array}{l}\text { Quality } \\
\text { of Life } \\
\text { Index } \\
\text { (QOL) }\end{array}$ & $\begin{array}{c}\text { Eco. } \\
\text { (Deficit) } \\
\text { or } \\
\text { Reserve } \\
\text { (global } \\
\text { ha. per } \\
\text { capita) }\end{array}$ \\
\hline Latest measurement & 2005 & 2006 & 2008 & 2005 & 2008 & 2005 & 2002 & 2001 & 2006 & 2005 & 2005 \\
\hline Number of countries & 142 & 142 & 138 & 137 & 137 & 142 & 139 & 142 & 142 & 99 & 142 \\
\hline Country & rank & rank & rank & rank & rank & rank & rank & rank & rank & rank & rank \\
\hline Syria & 71 & 79 & 93 & 115 & 126 & 115 & 100 & 143 & 58 & 86 & 110 \\
\hline Tajikistan & 6 & 93 & 75 & 129 & 90 & 47 & 76 & 122 & 16 & 96 & 68 \\
\hline Tanzania & 37 & 117 & 106 & 61 & 96 & 35 & 122 & 109 & 104 & 98 & 60 \\
\hline Thailand & 76 & 63 & 49 & 71 & 120 & 85 & 85 & 103 & 20 & 34 & 109 \\
\hline Togo & 12 & 123 & 109 & 108 & 97 & 73 & 114 & 58 & 95 &.. & 51 \\
\hline Trinidad and Tobago & 75 & 45 & 84 & 134 & 99 & 135 & 46 & 62 & 28 & 43 & 67 \\
\hline Tunisia & 64 & 71 & 55 & 53 & 105 & 84 & 63 & 93 & 14 & 73 & 94 \\
\hline Turkey & 89 & 59 & 68 & 89 & 37 & 118 & 72 & 104 & 70 & 42 & 107 \\
\hline Turkmenistan & 111 & 81 & 80 & 138 & 138 & 27 & 78 & 133 & 135 & 91 & 70 \\
\hline Uganda & 48 & 121 & 110 & 55 & 54 & 64 & 132 & 142 & 126 & 90 & 87 \\
\hline Ukraine & 88 & 64 & 71 & 106 & 50 & 95 & 59 & 105 & 139 & 87 & 73 \\
\hline United Arab Emirates & 143 & 26 & 105 & 107 & 135 & 74 & 95 & 140 & 121 & 60 & 143 \\
\hline United Kingdom & 129 & 19 & 13 & 64 & 47 & 132 & 21 & 25 & 78 & 23 & 133 \\
\hline United States of America & 142 & 13 & 37 & 43 & 63 & 78 & 19 & 20 & 118 & 11 & 140 \\
\hline Uruguay & 131 & 38 & 34 & 3 & 32 & 36 & 26 & 8 & 36 & 38 & 13 \\
\hline Uzbekistan & 67 & 89 & 100 & 137 & 129 & 65 & 55 & 127 & 37 & 95 & 101 \\
\hline
\end{tabular}


Table 2-4 (continued)

\begin{tabular}{|c|c|c|c|c|c|c|c|c|c|c|c|}
\hline $\begin{array}{c}\text { Composite Indicator } \\
\text { Framework }\end{array}$ & $\begin{array}{c}\text { Eco. } \\
\text { Foot- } \\
\text { print } \\
\text { per } \\
\text { capita } \\
\text { (EF) }\end{array}$ & $\begin{array}{c}\text { Human } \\
\text { Dev. } \\
\text { Index } \\
\text { (HDI) }\end{array}$ & $\begin{array}{l}\text { Env. } \\
\text { Perfor- } \\
\text { mance } \\
\text { Index } \\
\text { (EPI) }\end{array}$ & $\begin{array}{l}\text { Env. } \\
\text { Sust. } \\
\text { Index } \\
\text { (ESI) } \\
\end{array}$ & $\begin{array}{l}\text { Sust. } \\
\text { Society } \\
\text { Index } \\
\text { (SSI) }\end{array}$ & $\begin{array}{c}\text { Env. } \\
\text { Vulner- } \\
\text { ability } \\
\text { Index } \\
\text { (EVI) }\end{array}$ & $\begin{array}{l}\text { Sust. } \\
\text { Dev. } \\
\text { Index } \\
\text { (SDI) }\end{array}$ & $\begin{array}{c}\text { Well- } \\
\text { being } \\
\text { Index } \\
\text { (WI) }\end{array}$ & $\begin{array}{c}\text { Happy } \\
\text { Planet } \\
\text { Index } \\
\text { (HPI) }\end{array}$ & $\begin{array}{l}\text { Quality } \\
\text { of Life } \\
\text { Index } \\
\text { (QOL) }\end{array}$ & $\begin{array}{c}\text { Eco. } \\
\text { (Deficit) } \\
\text { or } \\
\text { Reserve } \\
\text { (global } \\
\text { ha. per } \\
\text { capita) }\end{array}$ \\
\hline Latest measurement & 2005 & 2006 & 2008 & 2005 & 2008 & 2005 & 2002 & 2001 & 2006 & 2005 & 2005 \\
\hline Number of countries & 142 & 142 & 138 & 137 & 137 & 142 & 139 & 142 & 142 & 99 & 142 \\
\hline Country & rank & rank & rank & rank & rank & rank & rank & rank & rank & rank & rank \\
\hline Venezuela & 91 & 47 & 42 & 80 & 110 & 71 & 57 & 54 & 17 & 51 & 49 \\
\hline Vietnam & 41 & 86 & 72 & 122 & 6 & 123 & 97 & 90 & 8 & 53 & 90 \\
\hline Yemen & 20 & 104 & 131 & 132 & 133 & 70 & 115 & 128 & 22 &.. & 78 \\
\hline Zambia & 9 & 127 & 123 & 58 & 102 & 7 & 128 & 137 & 131 &.. & 29 \\
\hline
\end{tabular}

Examining Table 2-4, it is not difficult to appreciate that there is very little consistency among the different frameworks. In order to determine the degree of correlation that exists between them, a Pearson Product - Moment Correlation analysis was performed. By applying the Pearson correlation function to the two country rank lists of any given pair of frameworks, the analysis yields a correlation coefficient $(\mathrm{R})$ that indicates the type of relationship that exists between them. ${ }^{7}$ Table 2-5 presents the results of the analysis in the form of a correlation matrix. See Section 4.4. for more information about the Pearson Correlation method.

\footnotetext{
7 "If both variables increase together across countries, a positive correlation results in a value from 0 to +1.0 . Conversely, an inverse relationship between the metrics would yield a negative correlation coefficient, between 0 and -1.0 " (Wilson, et al., 2007). A value closer to 1.0 (or -1.0 ) indicates a stronger correlation.
} 
Table 2-5: Correlation Matrix of Selected Composite Indicator Frameworks Source: Created by the author using rank lists in Table 2-4.

\begin{tabular}{|c|c|c|c|c|c|c|c|c|c|c|c|}
\hline $\begin{array}{c}\text { Pearson Moment Correlation } \\
\text { Coefficient } \\
\text { (uses country rank lists) }\end{array}$ & $\begin{array}{c}\text { Ecological } \\
\text { Footprint Per } \\
\text { capita - } \\
\text { indexed (EF) } \\
\end{array}$ & $\begin{array}{l}\text { Human Dev. } \\
\text { Index (HDI) }\end{array}$ & $\begin{array}{l}\text { Env. } \\
\text { Performance } \\
\text { Index (EPI) }\end{array}$ & $\begin{array}{c}\text { Env. } \\
\text { Sustainability } \\
\text { Index (ESI) }\end{array}$ & \begin{tabular}{|c}
$\begin{array}{c}\text { Sustainable } \\
\text { Society Index } \\
\text { (SSI) }\end{array}$ \\
\end{tabular} & $\begin{array}{c}\text { Env. } \\
\text { Vulnerability } \\
\text { Index (EVI) } \\
\end{array}$ & $\begin{array}{c}\text { Sustainable } \\
\text { Dev. Index } \\
\text { (SDI) }\end{array}$ & $\begin{array}{l}\text { Wellbeing } \\
\text { Index (WI) }\end{array}$ & \begin{tabular}{|c|}
$\begin{array}{c}\text { Happy Planet } \\
\text { Index (HPI) }\end{array}$ \\
\end{tabular} & $\begin{array}{c}\begin{array}{c}\text { Quality of Life } \\
\text { Index (QOL) }\end{array} \\
\end{array}$ & $\begin{array}{c}\text { Ecological } \\
\text { (Deficit) or } \\
\text { Reserve (gha. } \\
\text { per capita) }\end{array}$ \\
\hline $\begin{array}{l}\text { Ecological Footprint Per } \\
\text { capita - indexed (EF) }\end{array}$ & 1.000 & & & & & & & & & & \\
\hline $\begin{array}{l}\text { Human Development Index } \\
\text { (HDI) }\end{array}$ & -0.847 & 1.000 & & & & & & & & & \\
\hline \begin{tabular}{|l} 
Environmental \\
Performance Index (EPI)
\end{tabular} & -0.665 & 0.864 & 1.000 & & & & & & & & \\
\hline $\begin{array}{l}\text { Environmental } \\
\text { Sustainability Index (ESI) }\end{array}$ & -0.408 & 0.432 & 0.587 & 1.000 & & & & & & & \\
\hline $\begin{array}{l}\text { Sustainable Society Index } \\
\text { (SSI) }\end{array}$ & -0.178 & 0.359 & 0.524 & 0.545 & 1.000 & & & & & & \\
\hline \begin{tabular}{|l} 
Environmental \\
Vulnerability Index (EVI)
\end{tabular} & 0.267 & -0.493 & -0.415 & 0.169 & -0.203 & 1.000 & & & & & \\
\hline $\begin{array}{l}\text { Sustainable Development } \\
\text { Index (SDI) }\end{array}$ & -0.793 & 0.919 & 0.886 & 0.534 & 0.485 & -0.428 & 1.000 & & & & \\
\hline Wellbeing Index (WI) & -0.534 & 0.650 & 0.717 & 0.655 & 0.586 & -0.179 & 0.749 & 1.000 & & & \\
\hline Happy Planet Index (HPI) & 0.043 & 0.210 & 0.314 & 0.049 & 0.135 & -0.332 & 0.221 & 0.077 & 1.000 & & \\
\hline Quality of Life Index (QOL) & -0.627 & 0.842 & 0.699 & 0.478 & 0.439 & -0.382 & 0.737 & 0.678 & 0.124 & 1.000 & \\
\hline \begin{tabular}{|l} 
Ecological (Deficit) or \\
Reserve (gha. per capita)
\end{tabular} & 0.350 & -0.447 & -0.271 & 0.293 & 0.013 & 0.709 & -0.294 & -0.034 & -0.132 & -0.229 & 1.000 \\
\hline
\end{tabular}

As an example of how the results listed in Table 2-5 are interpreted, note the strong negative correlation between EF and HDI (-0.847); this indicates that countries that have low Ecological Footprints per capita (a 'good' thing) tend to have a low Human Development Index (a 'bad' thing). 


\subsection{Conclusion}

The comparative analysis of composite indicator frameworks shows that most frameworks have negative correlations with the Ecological Footprint per capita (EF). Notable exceptions are the Happy Planet Index (HPI) and the Environmental Vulnerability Index (EVI), which are not surprising if examined carefully. The HPI is calculated using Ecological Footprint data (plus Life Expectancy measures combined with a subjective assessment of satisfaction with life). The EVI shows a weak, but positive, correlation with the EF; it also shows the strongest positive correlation with Ecological Reserves, meaning that countries that are less 'vulnerable' to disaster tend to have ecological reserves and not deficits, which makes perfect sense.

Now, why are these conclusions focusing on the EF? The reason is that, if the EF is considered as a valid approach, then all the other composite indicator frameworks reviewed are inadequate. But, is the EF a valid approach? It certainly is the only framework reviewed here where the final score obtained is based on 'real data,' not on weighting factors applied subjectively according to (expert) opinions. It is also the only comprehensive measure of human consumption, relative to ecosystem's carrying capacity, available today.

All this points to a general flaw in the usual approaches to assess sustainable development: they tend to value human development factors and a clean local environment, but gravely overlook overconsumption of remote resources and the exporting of pollution - which the EF does by allocating environmental impacts to the final consumer of goods and services, not to the producer. Can a country that is relying on more than its share of the Earth's resources to meet its needs be deemed 'sustainable'? These frameworks appear to be answering with a resounding 'yes'. ${ }^{8}$ As long as this continues to be so, development within the ecological limits imposed by the planet's carrying capacity is unlikely to become a priority for policy makers.

\footnotetext{
${ }^{8}$ For example, with an Environmental Performance Index of 95.5, Switzerland ranks highest in the world. Nevertheless, according to EF figures, each Swiss person needs 3.7 more global hectares of biocapacity than their fair Earth-share (of 2.1 gha. per capita) to maintain his/her lifestyle.
} 


\title{
3. What Should Sustainable Development Indicators Indicate?
}

\begin{abstract}
"'Do we have the right vision?' and 'do we have the right measurement system for attaining this vision?' are both critical questions that any entity interested in addressing sustainability must answer... The effectiveness of an indicator/metric system cannot be evaluated outside the context of how well it is able to measure the vision for which it was developed. Information quality attributes such as data completeness, accuracy, and precision also cannot be evaluated outside the context of these broader and more fundamental questions" (Mihyeon Jeon, et al., 2005).
\end{abstract}

\subsection{What is Sustainable Development?}

The ultimate purpose of this work is to identify indicators that could tell us if a country is on the right path towards achieving a sustainable state of development. In order to do that, one key question must be addressed first: what does sustainable development mean?

\subsubsection{Classic Concepts of Sustainable Development}

In its very essence, the concept of sustainable development implies development that can be sustained (through time). The most widely-used definition comes from the World Commission on Environment and Development (WCED), commonly referred to as the Brundtland Report. It states that sustainable development "...meets the needs of the present but does not compromise the ability of future generations to meet their own needs." Based on this definition, it could be argued that the only true form of development is the sustainable one. Any other kind of development (i.e., one that does compromise future generations' ability to meet their needs) is not development but eventual destruction.

A common approach to address sustainable development is to assess it from three separate dimensions: environmental, social, and economic dimensions, illustrated as three separate circles that have a small area in common. This approach has become known as the triple bottom line.' In reality, however, it is difficult to separate these dimensions into distinct categories, since they are inevitably linked. That is why it is preferable to view the three dimensions as concentric circles, one within the other: economic activity within the boundaries of society, and society within the boundaries of the natural environment. ${ }^{9}$ This scheme is illustrated in Figure 3-1, whereas Figure 3-2 describes the very basic links between the three dimensions.

\footnotetext{
${ }^{9}$ See Appendix E for a brief history of the concentric circles approach to sustainability.
} 
Figure 3-1: The Dimensions of Sustainable Development

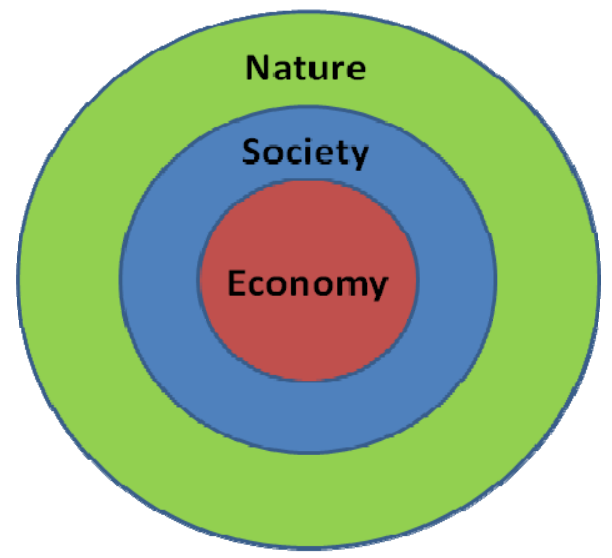

Source: Adapted from Tarté, 2006.

Figure 3-2: Basic Links between the Dimensions of Sustainable Development

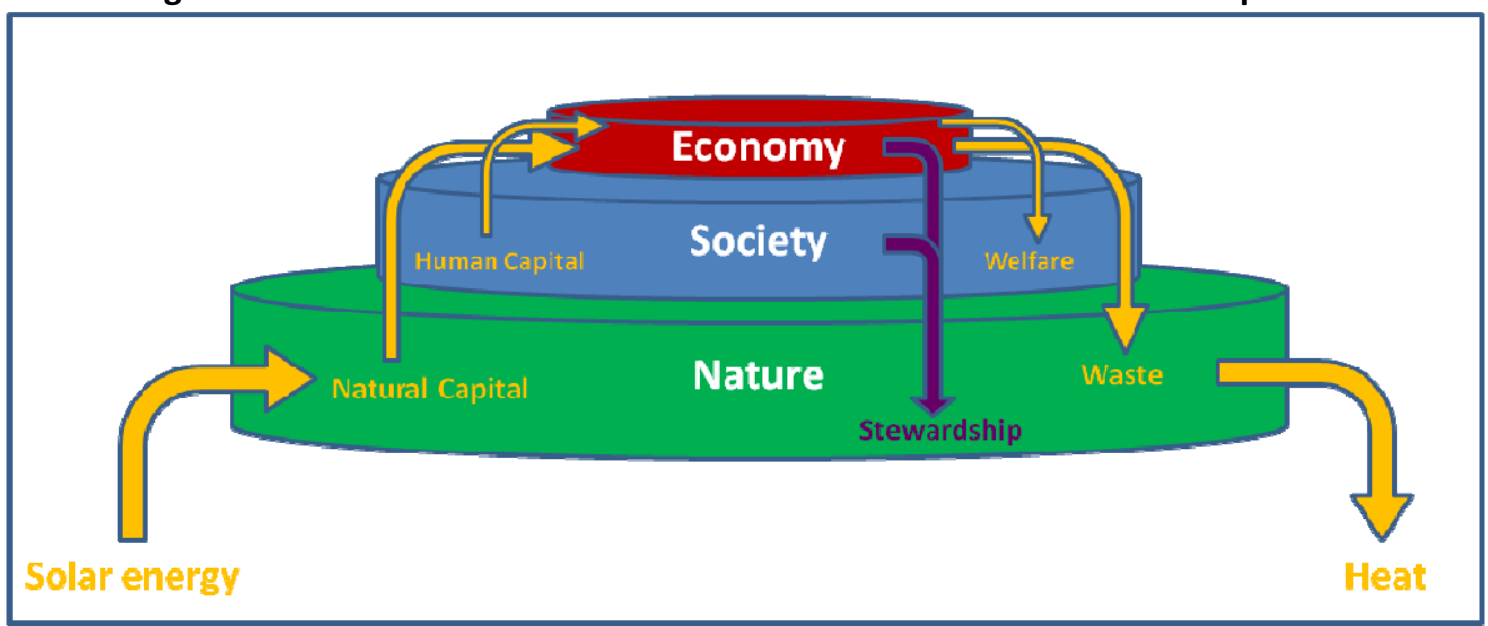

Source: Created by the author.

\subsubsection{A Basic Equation for Sustainable Development}

McDonach and Yaneske (2002) have suggested that, by dissecting the definition of sustainable development to its very basics, it could be represented using the following equation:

Sustainable development requirements $(S)=$ anthropocentric requirements $(A)+$ biocentric requirements $(B)$

The authors continue stating that, following this formula, there can be 4 types of states that sustain themselves through time:

$\begin{array}{lll}\text { Type 0: } & O B+O A & \text { devoid of life } \\ \text { Type 1: } & \quad 1 B+O A & \text { pristine nature (humans optional) }\end{array}$


Type 2: $\quad 1 B+1 A \quad$ current objectives of sustainable dev.

Type 3: $\quad 0 B+1 A \quad$ completely engineered environment

In broad terms, the type 2 state can only be achieved globally if all nations agree to $(A)$ meet their human needs, while (B) "...preserving non-renewable resources and living within the natural renewing capacity of the biosphere" (Frey, et al., 2007). It is in following this type of logic where the foundation lies for the conception of the Global Sustainability Quadrant.

\subsection{The Sustainability Quadrant Approach}

The "Sustainable Development Quadrant" was introduced as such by Boutaud A., 2002, and has been used since in a couple of joint publications by the World Wildlife Fund (WWF) and the Global Footprint Network. ${ }^{10}$ On a two-dimensional plot of nations' Human Development Index vs. Ecological Footprint per capita, the sustainability quadrant is defined by the area where both dimensions satisfy the minimum requirements of sustainable development. This approach follows the same basic logic set forth in the previous section, where the UNDP's Human Development Index (HDI) serves as a proxy for (A) anthropocentric requirements, and the Ecological Footprint (EF) is used to represent the (B) biocentric requirements part of the equation.

Brief overviews of these two components are provided in the following sections, before arriving at a more in-depth definition of the Global Sustainability Quadrant in Section 3.2.3.

\subsubsection{The Human Development Index}

The Human Development Index (HDI) was introduced by the United Nations Development Programme in $1990^{11}$. It has become arguably the most prominent indicator of socio-economic development used globally today. The HDI "measures a country's average achievements in three basic aspects of human development: health, knowledge, and a decent standard of living. Health is measured by life expectancy at birth; knowledge is measured by a combination of the adult literacy rate and the combined primary, secondary, and tertiary gross enrollment ratio; and standard of living by GDP per capita (PPP US\$)" (UNDP, Human Development Reports website, 2009). The UNDP considers an HDI equal to, or above 0.8 to mean 'high' human development.

Table 3-1 lists the dimensions and weighting factors used to calculate the HDI.

\footnotetext{
10 To name a few: WWF, GFN. Europe 2005: The Ecological Footprint; WWF, GFN. Asia-Pacific 2005: The Ecological Footprint and Natural Wealth.

${ }^{11}$ The HDI's calculation methodology was refined in 1999. Even though conceived in the 90 s, using historical data, the UNDP has been able to calculate the HDI for past years, starting in 1975.
} 


\section{Table 3-1: Calculation of the Human Development Index}

Source: Adapted from UNDP, 2008.

\begin{tabular}{|c|r|}
\hline \multicolumn{1}{|c|}{ Dimension } & \multicolumn{1}{c|}{ weight } \\
\hline Life Expectancy Index & $1 / 3$ \\
\hline Education Index & $1 / 3$ \\
\hline Adult Literacy Rate & $2 / 3$ \\
\hline Combined Gross Enrollment Ratio & $1 / 3$ \\
\hline GDP Index & $1 / 3$ \\
\hline
\end{tabular}

\subsubsection{The Ecological Footprint}

When thinking about trends that threaten humanity's sustainable development, population growth is usually at the top of the list. Even though the global growth rate is decreasing, it is ultimately in the rate of resource consumption where a population's true impact lies. The Ecological Footprint is a way to measure this consumption (the term 'footprint' symbolizes the mark humans leave on the planet), and to view it in light of the planet's carrying capacity. It puts human consumption in terms of the amount of 'biologically productive land and sea area,' or biocapacity, required to produce what is consumed and assimilate what is discarded.

The area of land or sea available to serve a particular use is called biocapacity, and represents the biosphere's ability to meet human demand for material consumption and waste disposal. The Ecological Footprint and biocapacity accounts cover six land use types: cropland, grazing land, fishing ground, forest land, built-up land and carbon uptake land (to accommodate the Carbon Footprint). For each component, the demand [volume] for ecological services is divided by the yield [volume/land area] for those ecological services to arrive at the Footprint [land area] of each land use type. Ecological Footprint and biocapacity are scaled with yield factors and equivalence factors to convert this physical land demanded to world average biologically productive land called global hectares [gha.]. This allows for comparisons between various land use types with differing productivities. (Ewing, et al., 2008).

"The Ecological Footprint uses yields of primary products (from cropland, forest, grazing land and fisheries) to calculate the area necessary to support a given activity.... A nation's consumption is calculated by adding imports to and subtracting exports from its national production" (Global Footprint Network website, accessed on April 2009). This means that the burden of resource consumption is assigned to the final consumer, not to the producer. The usual approaches used to measure sustainability tend to overlook this allocation of consumption.

Thus, a clean environment is not necessarily a sign of a society with a sustainable lifestyle - it could be masking a country's exporting of its environmental impacts. An exporting of the footprint happens when a country's Ecological Footprint is larger than its biocapacity; in other words, it is incurring an ecological deficit. 
Earth's amount of biocapacity available per capita is known as the fair Earth-share. The fair Earth-share is obtained by dividing Earth's total biocapacity (gha.) by its total population (number of persons). In 2005 (the year for which the latest measures are available), the fair Earth-share stood at 2.063 gha. per person. However, this fair Earth-share is being constantly reduced - despite some increases in productivity (e.g., agricultural yields) ${ }^{12}-$ due to the increase in the world's population. This trend will continue until global population stabilizes, unless the overall biological productivity of the land increases, at least, at the same rate.

Figure 3-3 illustrates how biocapacity and ecological footprint per capita have changed over the last 25 years. According to these data, humanity's ecological footprint per capita surpassed the planet's biocapacity in 1986. After that moment, humanity entered into what is commonly known as 'overshoot,' meaning that it is living in a way that is consuming the natural capital.

Figure 3-3: World Ecological Footprint and Biological Capacity per Capita (1980-2005)

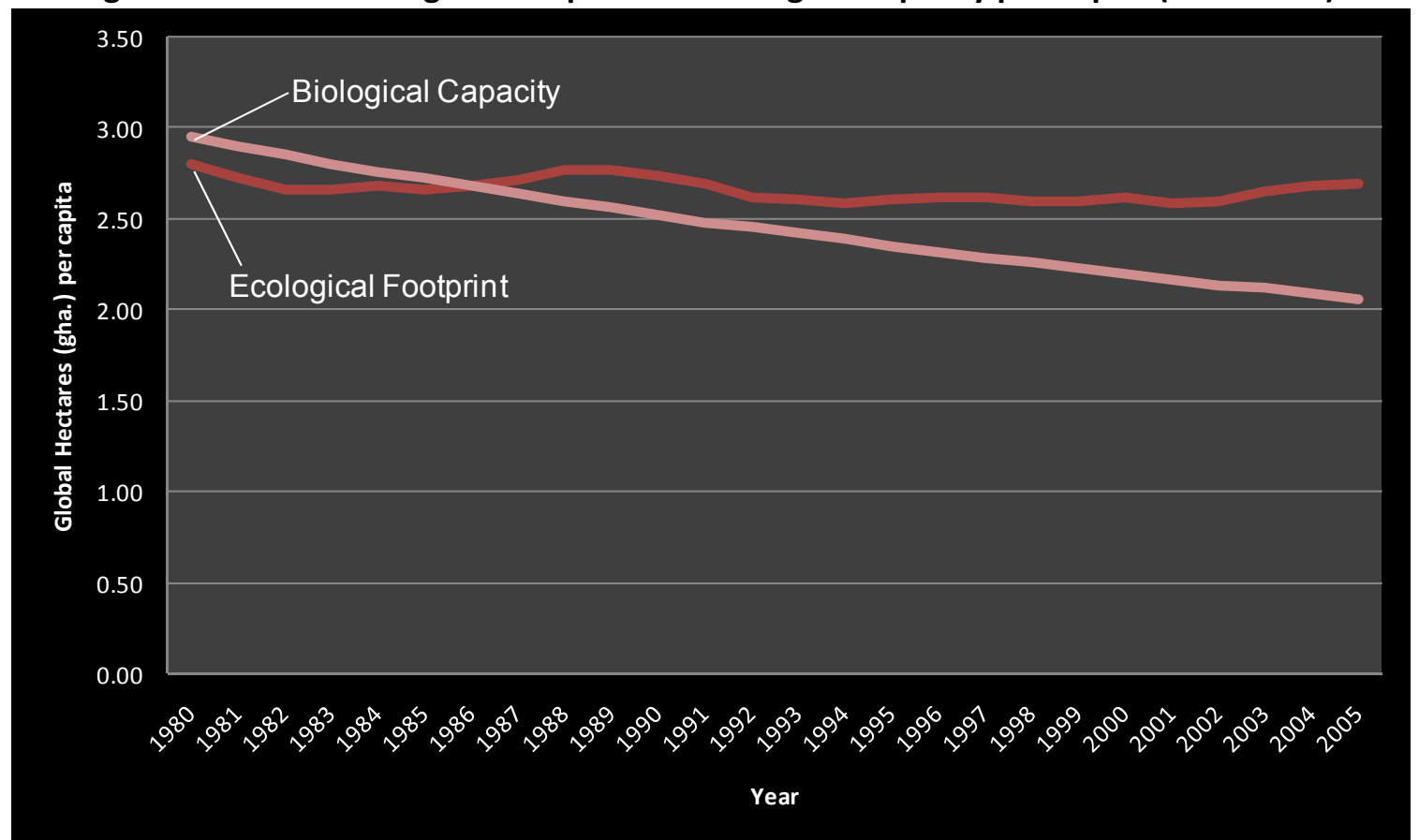

Sources: Global Footprint Network, National Footprint Accounts, 2008 edition. For more information about the Footprint methodology and calculation standards, contact Global Footprint Network at www.footprintnetwork.org.

Created by the author using MS Excel.

\footnotetext{
${ }^{12}$ Productivity of the land is indeed factored into the EF calculations. This means that the number of global hectares of cropland biocapacity entered into the footprint accounts is larger than the actual number of hectares of cropland.
} 


\subsubsection{The Global Sustainability Quadrant ${ }^{13}$}

On a two-dimensional plot of nations' Human Development Index vs. Ecological Footprint per capita, the Sustainability Quadrant is defined by the area where the minimum requirements of sustainability are met. These minimum requirements are defined by the Quadrant approach as:

- For the HDI, a score above $\mathbf{0 . 8}$ (considered 'high' human development by the UNDP).

- For the EF, $\mathbf{2 . 0 6 3}$ global hectares per capita (the latest estimates, from 2005, indicate that there are 2.063 global hectares of biocapacity per person in the planet; this is a person's fair Earth-share, and it makes sense that it is set as a minimum requirement of sustainability).

The term 'Global' has been added here to emphasize that this is a standard set for a sustainable global citizen. This means that sustainability is assessed in terms of the fair Earth-share of biocapacity, and not in terms of any particular country's amount of biocapacity.

Figure 3-4 is a plot of EF vs. HDI that, using data from 142 countries, illustrates the Global Sustainability Quadrant; this isthe number of countries that have both Ecological Footprint and Human Development Index figures available for $2005^{14}$.

${ }^{13}$ It should be noted that the Sustainability Quadrant approach is by no means the only effort that has been made to assess sustainable development by combining the EF and the HDI (or its components). Some of these efforts include:

- The Development Balance Index, proposed by Vintar Mally in her 2007 study, Linking SocioEconomic Development and Environmental Pressure. She proposes the following formula: Development balance index $=1 / 3$ GDP index $+1 / 3(1 / 2$ education index + $1 / 2$ life expectancy index) $+1 / 3$ ecological footprint index

- The Sustainable Human Development Index, proposed by Kenneth Hermele in his 2006 paper, Greening the Human Development Index.

- The Happy Planet Index (described briefly in the previous chapter and in greater detail in Appendix A).

${ }^{14}$ As of this publication, 2005 is the most recent year when complete country measures for both HDI and $\mathrm{EF}$ are available, so it has been taken to represent the 'present-day' in this work. 
Figure 3-4: The Global Sustainability Quadrant (2005)

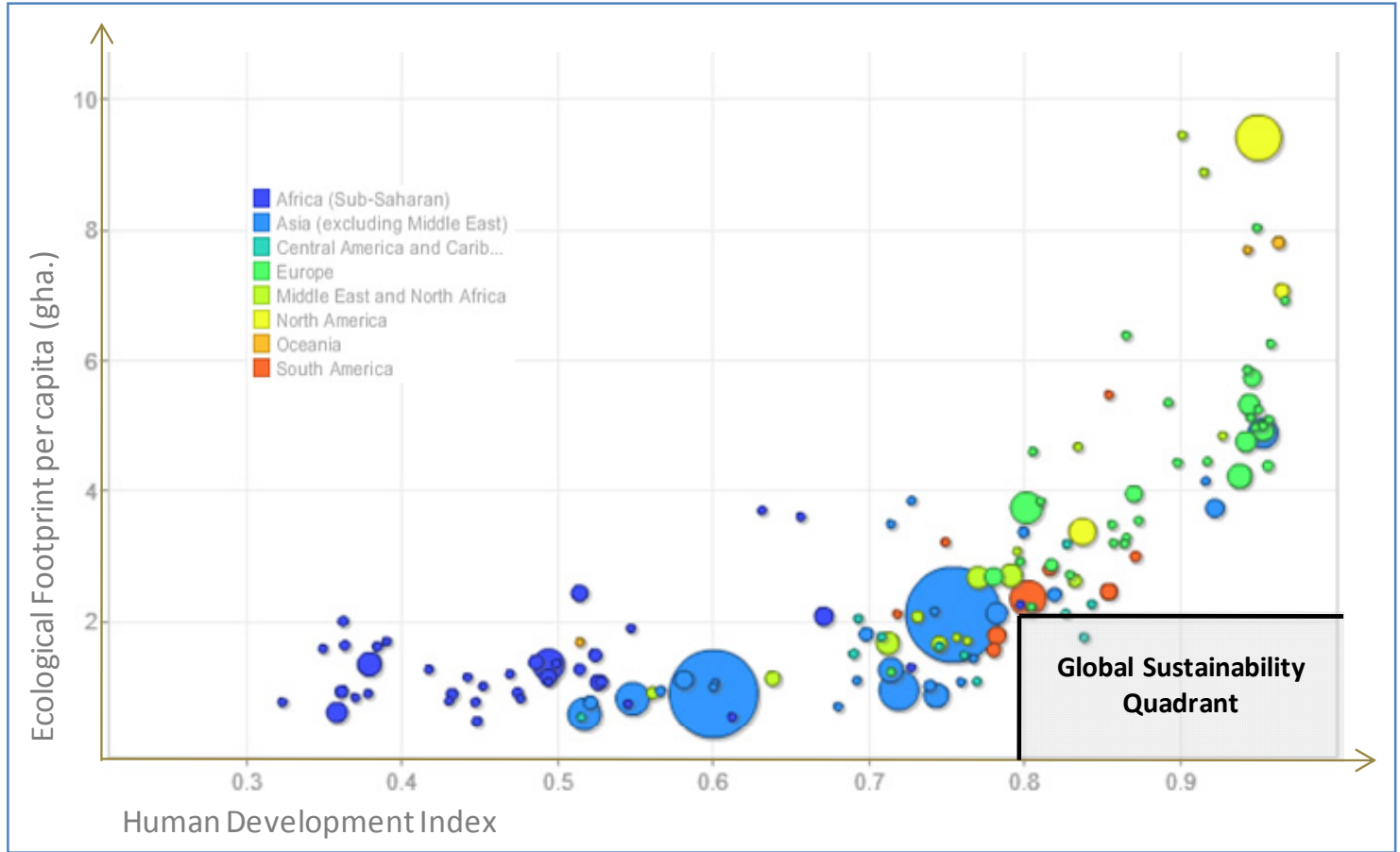

Note: Each circle in the Figure represents a country; the size of the circle is relative to the country's total population.

Sources: EF data obtained from the Global Footprint Network, National Footprint Accounts. 2008 edition. (www.footprintnetwork.org.) HDI Time Series obtained from the United Nations Development Programme (UNDP), Human Development Reports, 2008 (http://hdr.undp.org). Created by the author using Google Motion Chart and MS Power Point.

One thing that becomes evident by looking at Figure 3-4 is the 'development' pattern that nations seem to adhere to: as they advance their human development, their ecological footprint grows; they 'skim over' the Quadrant, which remains slightly within reach for a while, before shooting up into significant overconsumption. However, this does not mean that every country that improves its human development does it by increasing its footprint; there are exceptions. The Movement Towards the Quadrant assessment approach, which will be introduced in Section 4.3., allows us to identify the countries that are doing this, and to explore what sets them apart from the rest.

In the present-day, there is only one country inside the Quadrant: Cuba. ${ }^{15}$ Does this mean that Cuba can be viewed as a model for global sustainability? Not necessarily. Even though Cuba has achieved high human development within the ecological limits imposed by the planet's biocapacity, its Footprint per capita is rapidly increasing, ${ }^{16}$ so it is not expected to remain inside

${ }^{15}$ Cuba's case makes a very interesting study for sustainable development theorists. In his classic article, The Tragedy of the Commons, Garret Hardin (1968) observes that coercive public policies are the only way to avert the collapse of society brought upon by environmental degradation. Communist Cuba's presence inside the Sustainability Quadrant may have proven his point.

${ }^{16}$ As indicated by the EF Time Series. 
the Quadrant for much longer. This illustrates why assessing historical trends is more relevant to identify globally replicable models of sustainable development than present-day proximity to the Quadrant.

\subsubsection{Limitations of the Approach}

The value of this work ultimately depends on whether the reader considers the Ecological Footprint and the Human Development Index as valid approaches or not.

If the components of the HDI (health, knowledge, and standard of living) are deemed not sufficient to indicate true human development, then, as a measure of sustainable development, the Sustainability Quadrant approach will inevitably fall short of delivering reliable results.

The Global Footprint Network acknowledges several limitations ${ }^{17}$ in their EF methodology. Aside from the usual considerations of data reliability and measuring difficulties, the EF does not, and really cannot, incorporate the impacts of most types of pollutants (e.g., there is no ' $\mathrm{SO}_{2}$ uptake land'), unless this pollution brings about severe degradation of measurable extents of land, thus resulting in a loss of their productivity (i.e., a reduction in biocapacity).

Also, the EF cannot account for biodiversity directly, only when it serves as carbon uptake land, or indirectly as the ecological services it provides impact the land's productivity. Thus, biodiversity as such is excluded from the 'biocentric requirements' part of the sustainability equation.

Human-caused climate change skeptics will also be quick to dismiss this approach, because the EF includes nations' carbon footprint (i.e., the amount of carbon uptake land needed to absorb the $\mathrm{CO}_{2}$ emitted by human activities). If human carbon emissions were proven to have no incidence on climate change, most nations' ecological footprint would be greatly reduced.

But even with all its limitations considered, the Ecological Footprint is an invaluable tool in the assessment of sustainable development. It is the only comprehensive measure of human consumption relative to the limits imposed by the natural environment, available today. Moreover, it is based on 'real' and measurable data: yields of primary products, imports, and exports.

Finally, the Sustainability Quadrant approach itself does not factor in population growth. This means that, due to the resulting decrease in biocapacity per capita over time, the standard of sustainability will constantly be moving - the Quadrant will become progressively smaller.

\footnotetext{
${ }^{17}$ Appendix A provides a more in-depth overview of the EF approach, including limitations to its methodology and calculation standards.
} 


\subsection{Research Objective}

The Global Sustainability Quadrant has set a target for global sustainable development: HDI >= 0.8 , and $\mathrm{EF}=<2.063$ gha. per capita. The objective of this work is to:

- Identify the countries that are closest to the Quadrant in the present-day, and most importantly, those that are moving towards it in time, and to

- Determine what individual indicators of performance contribute to set these countries apart.

The first part of the objective will be achieved by devising a method to estimate proximity and historical movement in relation to the Quadrant, which would permit to rank countries accordingly. The latter part shall be accomplished by compiling data - a wide array of environmental, social, economic, and governance performance metrics - from all over the world and determining their relationship with proximity and/or movement relative to the Quadrant.

Put in different terms, this work aims to identify the metrics that are associated with the advancement (or the hindrance) of both types of sustainability requirements simultaneously. Note that the words used in the above description are 'associated with', not 'causing'. It is unrealistic to expect that this work will arrive at a new assessment index for global sustainability, much less a mathematical formula to model it. It can, however, provide a solid stepping stone for developing better indicators, and perhaps aid policy-makers and other researchers in future endeavors. 


\section{Methodology}

This chapter explains how individual metrics are identified as potential indicators of sustainable development based on the Global Sustainability Quadrant Approach defined in Section 3.2. The following sections describe this process in detail, but it can be summed up, in very broad terms, as follows:

- The Ecological Footprint per capita is transformed into an index score so that countries' performance can be assessed in conjunction with the Human Development Index, thus giving both axes of the HDI vs. EF plot standardized units (index score).

- Methods are devised to calculate (1) present-day Distance From the Quadrant and (2) historical Movement Towards the Quadrant, and countries are ranked accordingly.

- Individual metrics (current figures, as well as historical trends) are selected for the analysis and a country rank list is created for each one.

- Each metric's rank list is then compared to the (1) present-day Distance From the Quadrant rank list, and/or to the (2) historical Movement Towards the Quadrant rank list using the Pearson Product - Moment Correlation function in order to find statistically significant correlations.

It should be noted that in this analysis, both the HDI and EF dimensions are given equal weight; in other words, an index point gained on any axis accounts for the same amount of overall progress. In reality, it is unlikely that both dimensions would have the same degree of influence on overall sustainable development. Nevertheless, to assess overall progress more accurately, the following question would have to be answered with certainty: Is it easier to improve health, knowledge, and standard of living for the world's population, or to lower its consumption patterns? Historical HDI and EF trends worldwide suggest that the former is the case, so the EF dimension should probably carry more weight in the Quadrant assessment approach. Still, any weighing factor added at this point - without further research into the matter - would be no more than an educated guess.

\subsection{Transforming the Ecological Footprint Into an Index}

To assess a country's Ecological Footprint per capita (EFpc) in conjunction with the Human Development Index (HDI), it is necessary to transform the global hectares per capita value into and index score between 0 and 1 . This would give both axes of the HDI vs. EF plot standardized units (index score).

First, minimum and maximum values, known as goalposts, need to be set for the EFpc. Since a high EFpc is 'bad,' and a low EFpc is 'good,' the maximum goalpost will be equivalent to a score of 0.0 , and the minimum will be equivalent to a 1.0. In other words, the EF Index improves (i.e., moves closer to 1) as the country's EFpc decreases. Figure 4-1 illustrates how this works. 
Figure 4-1: Transforming EF into and Index using Goalpost Values

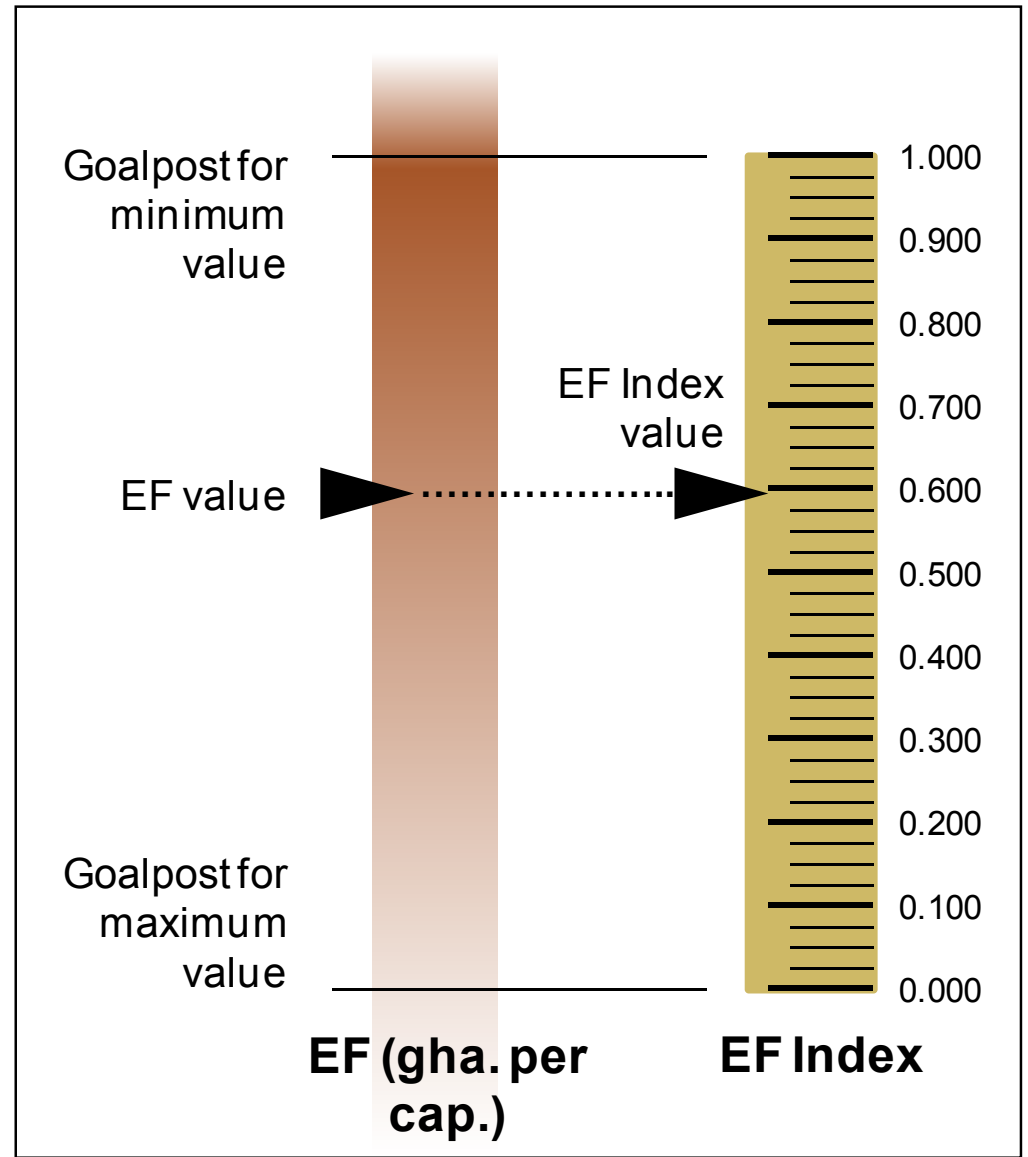

Source: Adapted from UNDP, 2008 (Technical Note 1).

Other approaches that combine EF and HDI measures (mentioned briefly in Section 3.2.), use different methods to set adequate EFpc goalpost values:

- "The ecological component of SHDI [Sustainable Human Development Index] has two limit values. The value 0 is defined as being equal to the largest country footprint (i.e. to the footprint of the USA which in 2001 equaled 9.5 ha/cap); the value 1 is set at the sustainability level for global equity [the fair Earth-share]" (Hermele, 2006). This approach rewards countries with footprints below the fair Earth-share, thus allowing some countries to have EF Index scores above 1.0.

- In the calculation of the Happy Planet Index, the New Economics Foundation has also transformed the Efpc into an indexed score. Their maximum goalpost is set at 15 gha. "Setting the maximum at 15 is well above highest value of 9.5 gha, but not as high as to imply that the current country scores are low in absolute terms. In any case, the impact of this maximum value comes out in the wash - it has no effect on the overall rank order of countries, only on the absolute scores." (Marks et. Al., 2006). 
- Development Balance Index "Maximal value used for the ecological footprint index calculation was 10.0 global ha per capita. At the beginning of $21^{\text {st }}$ century no country exceeded this limit, while in many countries ecological footprint was less than 1.0 global ha per capita. Therefore, minimum value was rounded up and set at 0.0 global ha per capita, representing (theoretically) minimal possible pressures on the environment." (Vintar Mally, 2007).

After testing several different methods and goalpost values, the approach that was chosen for this work is very similar to the one used in the third approach (Development Balance Index). The goalpost values were set as follows:

- The minimum value was set at 0.0 gha. per capita - a theoretical ideal representing zero environmental pressure.

- The maximum value was set at 10.3 gha. per capita - this value ensures that an EF Index score of 0.8 (which on the HDI is considered 'high') equals exactly 2.063 gha., the fair Earth-share in 2005; thus, countries with a score above 0.8 are living within the planet's carrying capacity, and can be considered to have 'high' EF scores. As a fortunate coincidence, the highest Efpc value found on the entire EF time series used in the analysis (from 1980 to 2005) was 10.3 gha. (for Norway, in 1980), which ensures that all countries in the analysis fall within the range set by the minimum and maximum goalposts.

After having set the desired goalpost values, the following formula is used to obtain the EF indexed score:

$$
E F \text { Index }=\frac{\text { maximum value }- \text { actual value }}{\text { maximum value }- \text { minimum value }}
$$

Plugging in the goalpost values, the formula becomes:

$$
E F \text { Index }=\frac{10.3 \text { gha. }- \text { actual value }}{10.3 \text { gha. }}
$$

Table 4-1 provides a sample of the 2005 EFpc values transformed into an Index for a few selected countries. 
Table 4-1: Sample 2005 Ecological Footprint Values Transformed into an Index Score Source: Created by the author.

\begin{tabular}{|l|r|r|}
\hline \multicolumn{1}{|c|}{ Country } & EF (gha. per capita) & EF Index \\
\hline Malawi & 0.47 & 0.954 \\
\hline Nicaragua & 2.05 & 0.801 \\
\hline South Africa & 2.08 & 0.798 \\
\hline Belgium & 5.13 & 0.502 \\
\hline United Arab Emirates & 9.46 & 0.082 \\
\hline
\end{tabular}

Figure 4-2 plots the HDI vs. EF using the EF Index instead of the gha. per capita values. The Global Sustainability Quadrant is now defined by scores equal or greater than 0.8 on both axes. Since the desirable state (a low EFpc) is now a high index value on the vertical axis, the Quadrant appears on the upper right-hand corner. Nevertheless, the countries' relative proximity to each other and to the Quadrant remains unchanged (it is as though the image had been simply flipped on its horizontal axis).

Figure 4-2: The Global Sustainability Quadrant using the EF Indexed Score (2005)

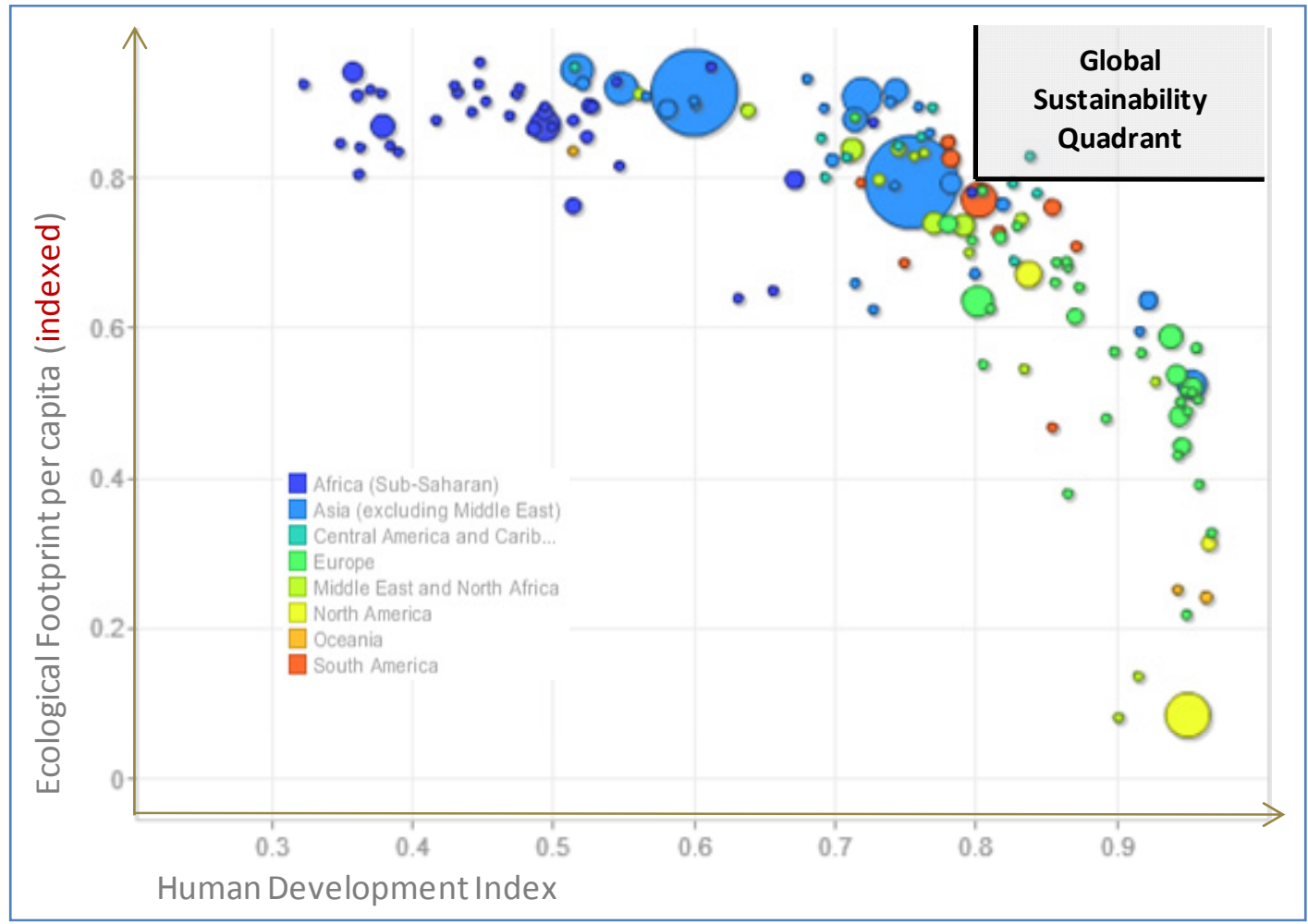

Note: Each circle represents a country, the size of the circle is relative to the country's population.

Sources: Global Footprint Network, 2008; UNDP, 2008.

Created by the author using Google Motion Chart and MS Power Point. 


\subsection{Present-Day Distance From the Quadrant}

As outlined in the Research Objective (Section 3.3.), part of this work's aim is to identify metrics that could serve as indicators associated with proximity to the Global Sustainability Quadrant in the present-day. In order to accomplish this, a method to calculate countries' Distance From the Quadrant has to be devised, so they can be ranked accordingly.

The countries selected for this analysis total 142 , which is the number of countries that have both Ecological Footprint and Human Development Index figures available for $2005 .{ }^{18}$ Thus, they are the only countries where it is now possible to estimate present-day Distance from the Global Sustainability Quadrant.

\subsubsection{Calculating Present-day Distance From the Quadrant}

Of all the countries included in the present-day analysis, only one (Cuba) is inside the Quadrant - both its HDI and EF Index are high (above 0.8). All the other countries either have only a high HDI, or a high EF Index, or neither. Estimating Distance From the Quadrant for those countries that rank high on one dimension is fairly easy: simply subtract the actual value from 0.8 on the axis where performance is not high. It is those countries that rank below 0.8 on both axes that present a calculation challenge. To estimate such countries' Distance From the Quadrant, the difference from 0.8 on each axis is first determined, and then the hypotenuse of the right angled triangle formed between the two differences - that is, the shortest distance to the Quadrant's lower corner $(0.8,0.8)$ - is calculated using the Pythagorean theorem. ${ }^{19}$ Figure $4-3$ illustrates how this is done.

\footnotetext{
${ }^{18}$ As of this publication, 2005 is the most recent year when complete country measures for both HDI and EF are available, so it has been taken to represent the 'present-day' in this work.

${ }^{19}$ Since both the HDI and EF index dimensions are given equal weight in this analysis, when plotted they form a coordinate system with equivalent units, which allows for the application of vector algebra principles.
} 
Figure 4-3: Calculating Present-Day (2005) Distance from the Sustainability Quadrant

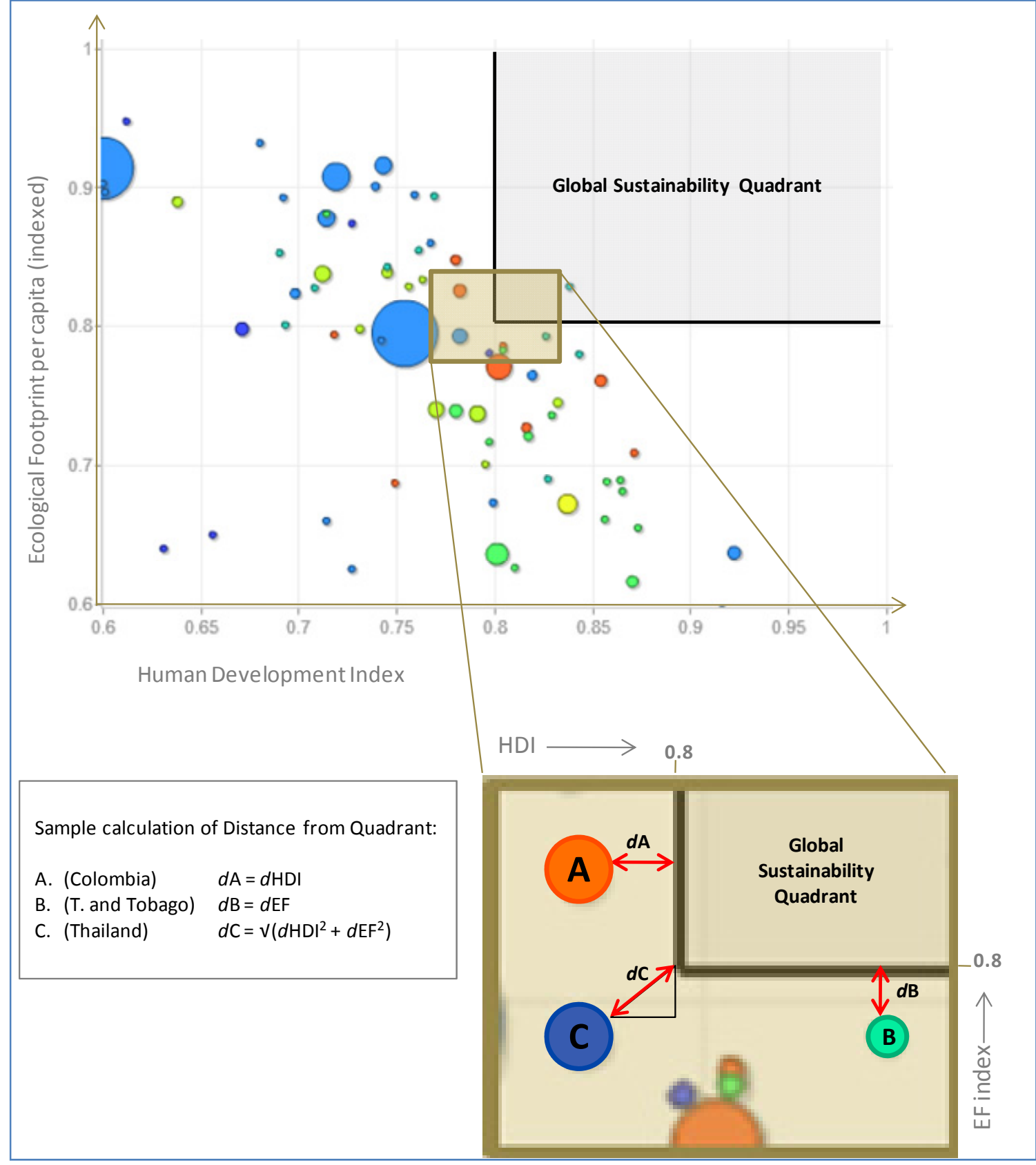

Source: Created by the author using Google Motion Chart and MS Power Point. Data from: Global Footprint Network, 2008; UNDP, 2008. 


\subsubsection{Present-day Distance Country Rank List}

After calculating present-day Distance From the Quadrant for all countries in the study, a list that ranks them according to their proximity to the Quadrant is created: Table 4-2. Note that the top ranking countries in this list are not the ones that usually top the "Most Developed" lists published in the literature. As long as this continues to be so, development within the ecological limits imposed by the planet's carrying capacity is unlikely to become a priority for policy makers.

Table 4-2: Present-day (2005) Distance From the Quadrant - Country Rank List

Note: Country names are formatted to covey other relevant information about their sustainability-related performance. Names in italics indicate that these countries are running an ecological deficit (i.e., their Ecological Footprint per capita is larger than their own Biocapacity per capita); a name in bold font indicates that the country has a high Human Development Index (above 0.8), and a name that is highlighted indicates that the country's EF per capita is below the fair Earth-share of 2.063 gha. The desirable situation for any country would be to have ecological reserves (not deficit), high HDI, and a per capita EF below the fair Earth-share; unfortunately, not a single country meets all three criteria in the present-day Source: Created by the author. Data from: Global Footprint Network, 2008; UNDP, 2008.

\begin{tabular}{|l|c|c|}
\hline \multicolumn{1}{|c|}{ Country } & $\begin{array}{c}\text { Total Distance From } \\
\text { the Quadrant }\end{array}$ & Rank \\
\hline Cuba & 0.000 & 1 \\
\hline Trinidad and Tobago & 0.007 & 2 \\
\hline Ecuador & 0.014 & 3 \\
\hline Albania & 0.017 & 4 \\
\hline Colombia & 0.018 & 5 \\
\hline Thailand & 0.019 & 6 \\
\hline Mauritius & 0.019 & 7 \\
\hline Peru & 0.020 & 8 \\
\hline Costa Rica & 0.020 & 9 \\
\hline Brazil & 0.029 & 10 \\
\hline Jamaica & 0.031 & 11 \\
\hline Armenia & 0.033 & 12 \\
\hline Malaysia & 0.035 & 13 \\
\hline Jordan & 0.037 & 14 \\
\hline Argentina & 0.038 & 15 \\
\hline Dominican Republic & 0.039 & 16 \\
\hline Georgia & 0.041 & 17 \\
\hline Tunisia & 0.044 & 18 \\
\hline
\end{tabular}


Table 4-2 (continued)

\begin{tabular}{|c|c|c|}
\hline Country & $\begin{array}{c}\text { Total Distance From } \\
\text { the Quadrant }\end{array}$ & Rank \\
\hline China & 0.046 & 19 \\
\hline Saudi Arabia & 0.055 & 20 \\
\hline El Salvador & 0.055 & 21 \\
\hline Algeria & 0.055 & 21 \\
\hline Philippines & 0.057 & 23 \\
\hline Azerbaijan & 0.059 & 24 \\
\hline Sri Lanka & 0.061 & 25 \\
\hline Bulgaria & 0.064 & 26 \\
\hline Turkey & 0.064 & 27 \\
\hline Ukraine & 0.065 & 28 \\
\hline Iran & 0.067 & 29 \\
\hline Syria & 0.069 & 30 \\
\hline Venezuela & 0.073 & 31 \\
\hline Gabon & 0.073 & 32 \\
\hline Romania & 0.079 & 33 \\
\hline Indonesia & 0.081 & 34 \\
\hline Bolivia & 0.082 & 35 \\
\hline Bosnia Herzegovina & 0.084 & 36 \\
\hline Moldova Republic & 0.086 & 37 \\
\hline Vietnam & 0.086 & 37 \\
\hline Egypt & 0.088 & 39 \\
\hline Chile & 0.091 & 40 \\
\hline Honduras & 0.092 & 41 \\
\hline Lebanon & 0.099 & 42 \\
\hline Uzbekistan & 0.102 & 43 \\
\hline Nicaragua & 0.107 & 44 \\
\hline Kyrgyzstan & 0.108 & 45 \\
\hline Panama & 0.110 & 46 \\
\hline Guatemala & 0.110 & 47 \\
\hline Lithuania & 0.111 & 48 \\
\hline Croatia & 0.111 & 49 \\
\hline Slovakia & 0.119 & 50 \\
\hline Tajikistan & 0.120 & 51 \\
\hline Paraguay & 0.123 & 52 \\
\hline Kazakhstan & 0.127 & 53 \\
\hline
\end{tabular}


Table 4-2 (continued)

\begin{tabular}{|c|c|c|}
\hline Country & $\begin{array}{c}\text { Total Distance From } \\
\text { the Quadrant }\end{array}$ & Rank \\
\hline Mexico & 0.128 & 54 \\
\hline South Africa & 0.129 & 55 \\
\hline Latvia & 0.139 & 56 \\
\hline Hungary & 0.145 & 57 \\
\hline Morocco & 0.162 & 58 \\
\hline Korea Republic & 0.163 & 59 \\
\hline Russia & 0.164 & 60 \\
\hline Mongolia & 0.164 & 61 \\
\hline Belarus & 0.174 & 62 \\
\hline Poland & 0.184 & 63 \\
\hline Congo & 0.188 & 64 \\
\hline Turkmenistan & 0.190 & 65 \\
\hline Laos & 0.199 & 66 \\
\hline India & 0.200 & 67 \\
\hline Bhutan & 0.200 & 67 \\
\hline Singapore & 0.204 & 69 \\
\hline Botswana & 0.208 & 70 \\
\hline Germany & 0.210 & 71 \\
\hline Myanmar & 0.219 & 72 \\
\hline Netherlands & 0.226 & 73 \\
\hline Portugal & 0.231 & 74 \\
\hline Namibia & 0.233 & 75 \\
\hline Slovenia & 0.233 & 76 \\
\hline Cambodia & 0.234 & 77 \\
\hline Yemen & 0.239 & 78 \\
\hline Macedonia (TFYR) & 0.247 & 79 \\
\hline Pakistan & 0.252 & 80 \\
\hline Mauritania & 0.253 & 81 \\
\hline Oman & 0.254 & 82 \\
\hline Swaziland & 0.255 & 83 \\
\hline Italy & 0.262 & 84 \\
\hline Israel & 0.270 & 85 \\
\hline Madagascar & 0.272 & 86 \\
\hline Kenya & 0.274 & 87 \\
\hline Japan & 0.275 & 88 \\
\hline Ghana & 0.276 & 89 \\
\hline
\end{tabular}


Table 4-2 (continued)

\begin{tabular}{|c|c|c|}
\hline Country & $\begin{array}{c}\text { Total Distance From } \\
\text { the Quadrant }\end{array}$ & Rank \\
\hline France & 0.278 & 90 \\
\hline Nepal & 0.279 & 91 \\
\hline Bangladesh & 0.283 & 92 \\
\hline Austria & 0.283 & 93 \\
\hline Haiti & 0.285 & 94 \\
\hline Switzerland & 0.286 & 95 \\
\hline Cameroon & 0.286 & 96 \\
\hline Papua New Guinea & 0.286 & 96 \\
\hline Sudan & 0.288 & 98 \\
\hline Sweden & 0.295 & 99 \\
\hline Belgium & 0.298 & 100 \\
\hline Senegal & 0.301 & 101 \\
\hline Lesotho & 0.306 & 102 \\
\hline Tanzania & 0.306 & 102 \\
\hline Nigeria & 0.306 & 102 \\
\hline Finland & 0.309 & 105 \\
\hline Uganda & 0.314 & 106 \\
\hline United Kingdom & 0.317 & 107 \\
\hline Czech Republic & 0.320 & 108 \\
\hline Togo & 0.324 & 109 \\
\hline Angola & 0.326 & 110 \\
\hline Gambia & 0.331 & 111 \\
\hline Uruguay & 0.332 & 112 \\
\hline Benin & 0.348 & 113 \\
\hline Malawi & 0.352 & 114 \\
\hline Zambia & 0.353 & 115 \\
\hline Spain & 0.357 & 116 \\
\hline Eritrea & 0.358 & 117 \\
\hline Cote D'Ivoire & 0.368 & 118 \\
\hline Greece & 0.369 & 119 \\
\hline Rwanda & 0.370 & 120 \\
\hline Guinea & 0.383 & 121 \\
\hline Ireland & 0.408 & 122 \\
\hline Chad & 0.410 & 123 \\
\hline Mali & 0.416 & 124 \\
\hline Estonia & 0.421 & 125 \\
\hline
\end{tabular}


Table 4-2 (continued)

\begin{tabular}{|l|c|c|}
\hline \multicolumn{1}{|c|}{ Country } & $\begin{array}{c}\text { Total Distance From } \\
\text { the Quadrant }\end{array}$ & Rank \\
\hline Ethiopia & 0.421 & 126 \\
\hline Guinea-Bissau & 0.422 & 127 \\
\hline Burundi & 0.430 & 128 \\
\hline Niger & 0.437 & 129 \\
\hline Burkina Faso & 0.438 & 130 \\
\hline Mozambique & 0.439 & 131 \\
\hline Congo Dem Rep & 0.442 & 132 \\
\hline Central African Rep & 0.451 & 133 \\
\hline Norway & 0.471 & 134 \\
\hline Sierra Leone & 0.477 & 135 \\
\hline Canada & 0.486 & 136 \\
\hline New Zealand & 0.547 & 137 \\
\hline Australia & 0.558 & 138 \\
\hline Denmark & 0.580 & 139 \\
\hline Kuwait & 0.663 & 140 \\
\hline United States of America & 0.715 & 141 \\
\hline United Arab Emirates & 0.718 & 142 \\
\hline
\end{tabular}

Figures 4-4 and 4-5 illustrate where the countries closest to, and farthest from, the Quadrant stand today (2005) on the EF vs. HDI plot, respectively. 
Figure 4-4: Present-day (2005) Distance From the Quadrant - Top Performers

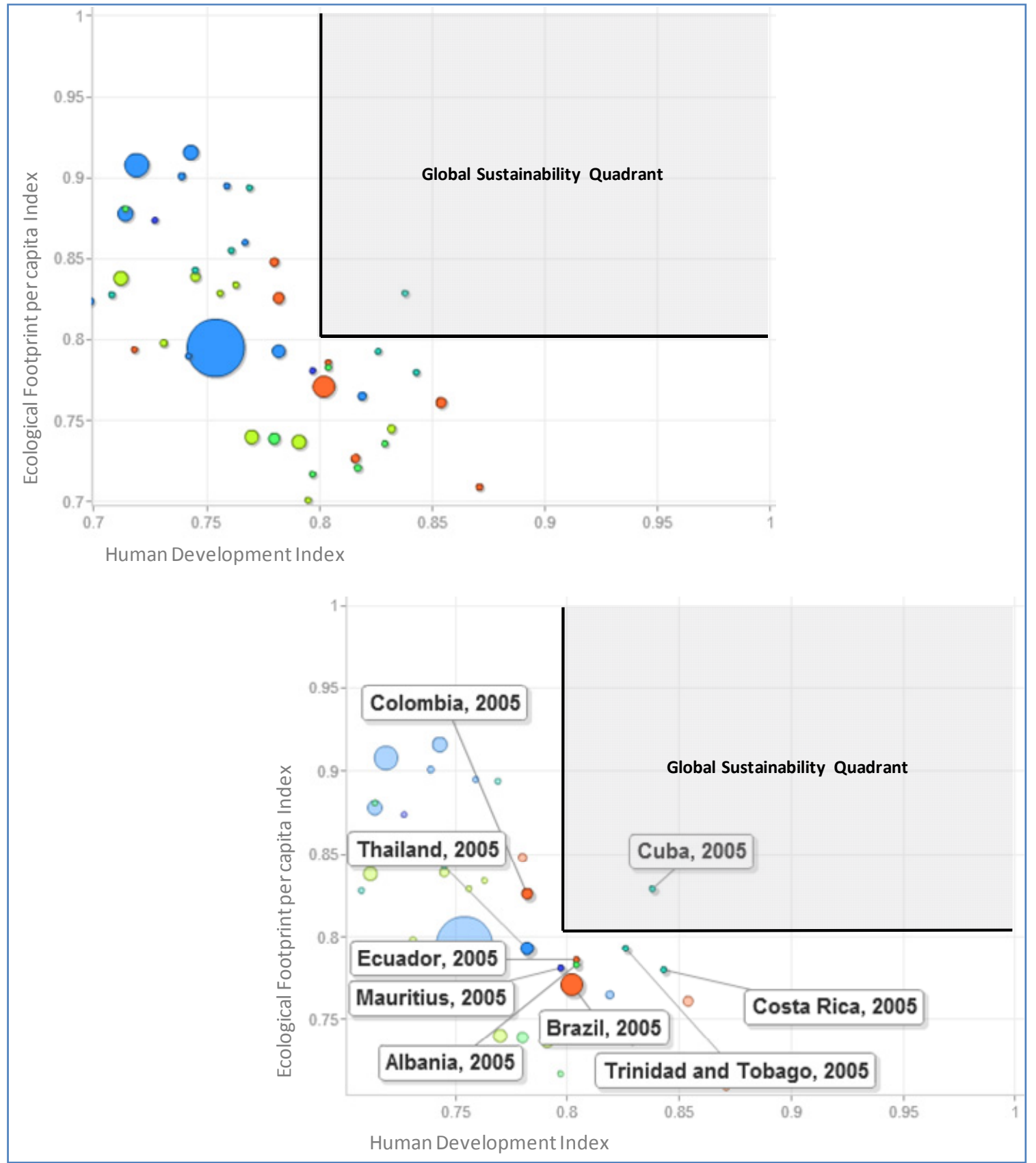

Source: Created by the author using Google Motion Chart and MS Power Point. Data from: Global Footprint Network, 2008; UNDP, 2008. 
Figure 4-5: Present-day (2005) distance From the Quadrant - Bottom Performers

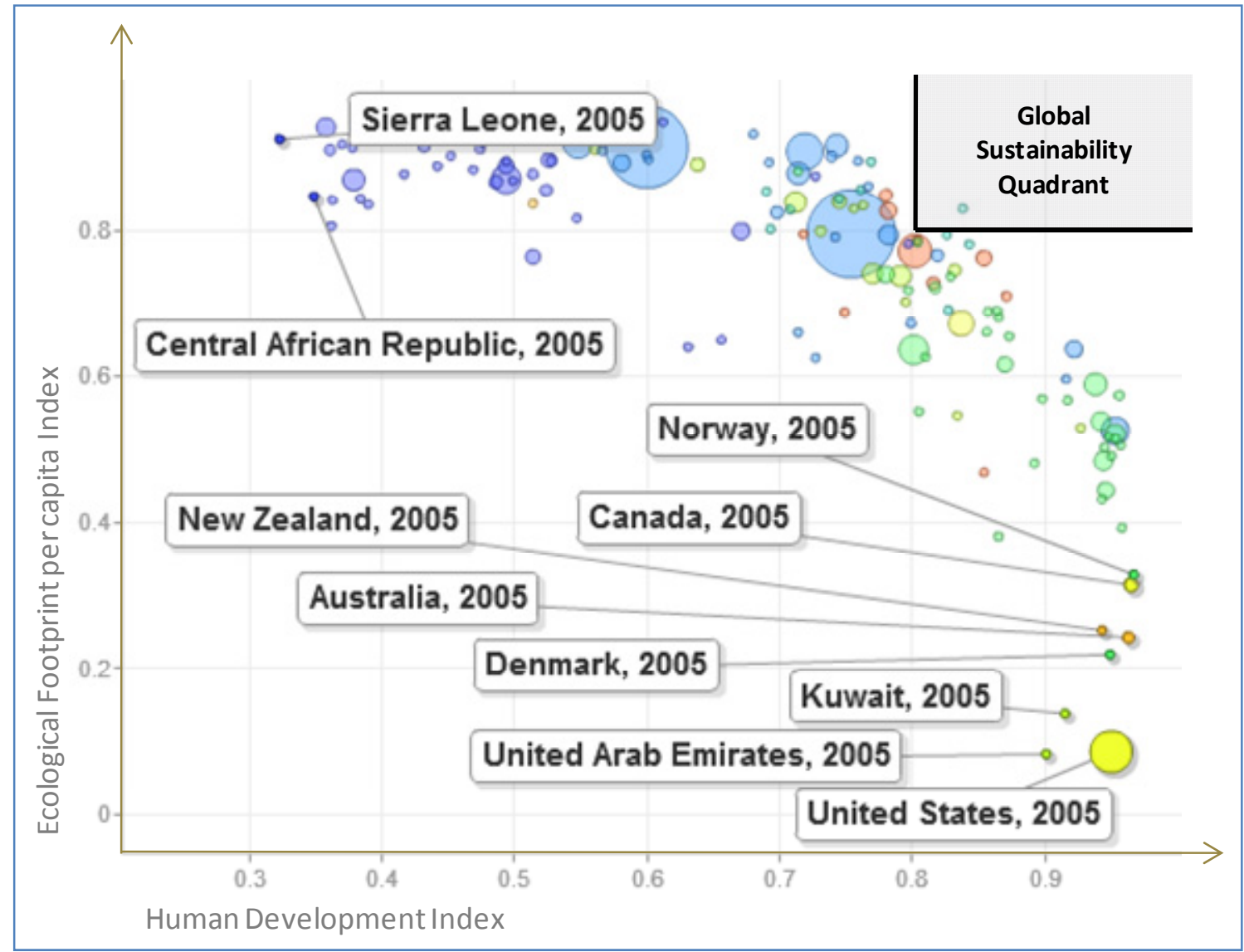

Source: Created by the author using Google Motion Chart and MS Power Point.

Figure 4-6 is a world map where countries have been shaded according to their Present-day Distance from the Quadrant; darker shades indicate closer proximity (i.e., good performance). 
Figure 4-6: Present-day (2005) Distance from Quadrant World Map (quintiles)

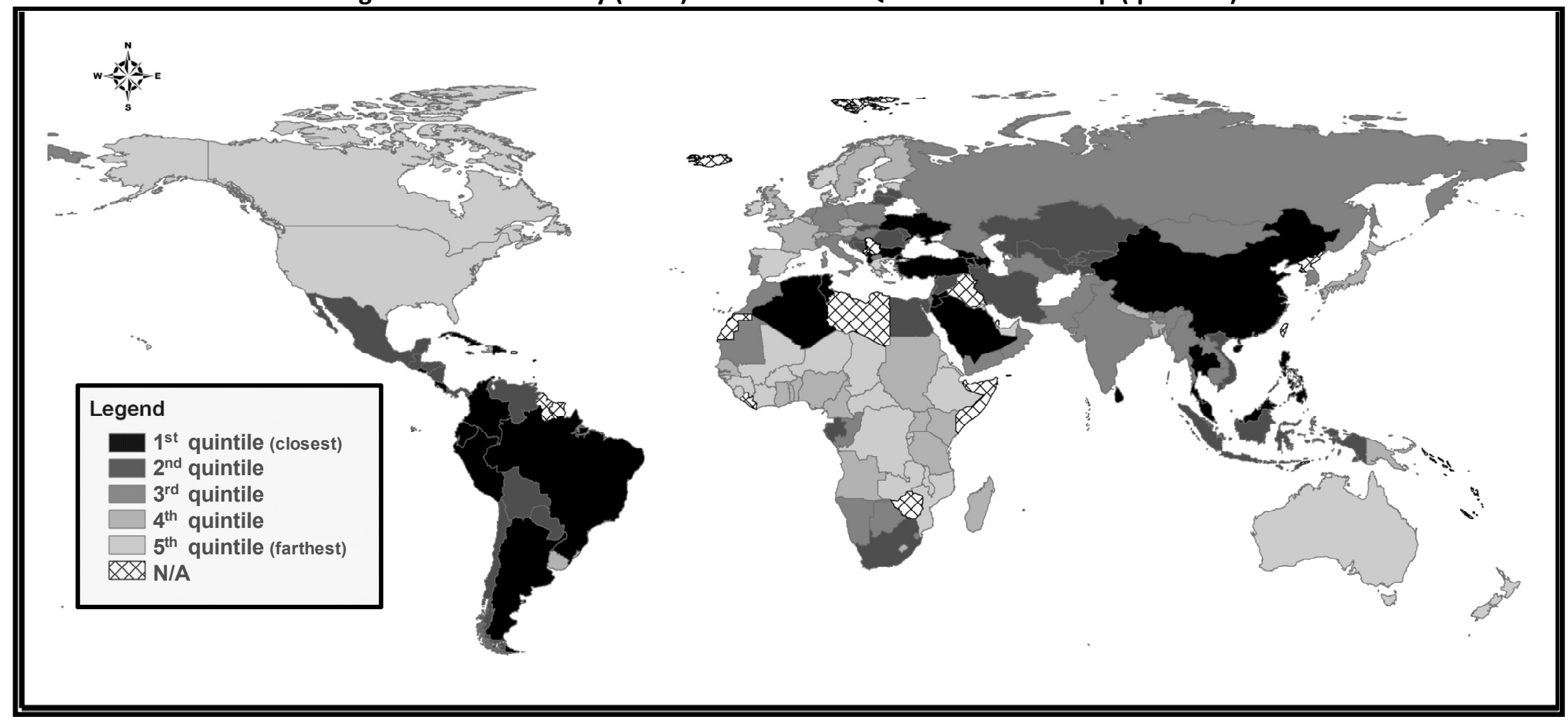

Source: Created by the author using ArcMap. Data from: Global Footprint Network, 2008; UNDP, 2008. World boundaries shapefile obtained from: DIVA-GIS, Thematic Mapping. World Countries Boundary File, World, 2002. Licensed under a Creative Commons Attribution 3.0 License. Downloaded from: http://finder.geocommons.com/overlays/5603 


\subsubsection{Comparing the Present-day Distance From Quadrant Approach with other Composite Sustainability Indicator Approaches}

Table 4-3 is an updated version of the Correlation Matrix of Selected Composite Indicator Approaches (Table 2.5.). It incorporates the Present-Day Distance from Quadrant approach into the analysis covered in Chapter 2.

Among the frameworks reviewed, the Happy Planet Index $(\mathrm{HPI})^{20}$ shows the best correlation with the Present-Day Distance from Quadrant approach ( $R=0.585)$. It is followed by the EPI, with a correlation coefficient $(R=0.304)$ that is not particularly strong, but still significant. The most significant negative correlation (-0.357) was found with the Quality of Life Index (QOL), which indicates that what this approach values very often is in conflict with the requirements for sustainable development set by the Global Sustainability Quadrant.

${ }^{20}$ It is no surprise that the Happy Planet Index (HPI) shows the strongest positive correlation with the Distance from Quadrant approach, after all, it is calculated using EF and Life Expectancy measures (one of the components of the HDI). For more information about the HPI, see Appendix A, or visit the HPI website: http://www.happyplanetindex.org. 
Table 4-3: Updated Indicator Correlation Matrix (Includes Distance From the Quadrant Approach) Source: Created by the author using rank lists in Tables 2-4 and 4-2.

\begin{tabular}{|c|c|c|c|c|c|c|c|c|c|c|c|c|}
\hline $\begin{array}{c}\text { Pearson Moment } \\
\text { Correlation Coefficient } \\
\text { (uses country rank lists) }\end{array}$ & $\begin{array}{c}\text { HDI + EF } \\
\text { Distance } \\
\text { from } \\
\text { Quadrant }\end{array}$ & $\begin{array}{c}\text { Ecological } \\
\text { Footprint } \\
\text { Per capita - } \\
\text { indexed (EF) }\end{array}$ & \begin{tabular}{|c|} 
Human Dev. \\
Index (HDI)
\end{tabular} & \begin{tabular}{|c|} 
Env. Perfor- \\
mance Index \\
(EPI)
\end{tabular} & $\begin{array}{l}\text { Env. Sust. } \\
\text { Index (ESI) }\end{array}$ & $\begin{array}{c}\text { Sustainable } \\
\text { Society } \\
\text { Index (SSI) } \\
\end{array}$ & $\begin{array}{c}\text { Env. } \\
\text { Vulnerabi- } \\
\text { lity Index } \\
\text { (EVI) }\end{array}$ & $\begin{array}{c}\text { Sustainable } \\
\text { Dev. Index } \\
\text { (SDI) }\end{array}$ & $\begin{array}{l}\text { Wellbeing } \\
\text { Index (WI) }\end{array}$ & $\begin{array}{c}\text { Happy } \\
\text { Planet Index } \\
\text { (HPI) } \\
\end{array}$ & $\begin{array}{c}\text { Quality of } \\
\text { Life Index } \\
\text { (QOL) }\end{array}$ & $\begin{array}{c}\text { Eco. (Deficit) } \\
\text { or Reserve } \\
\text { (gha. per } \\
\text { capita) } \\
\end{array}$ \\
\hline $\begin{array}{l}\text { HDI + EF Distance from } \\
\text { Quadrant }\end{array}$ & 1.000 & & & & & & & & & & & \\
\hline $\begin{array}{l}\text { Ecological Footprint Per } \\
\text { capita - indexed (EF) }\end{array}$ & 0.072 & 1.000 & & & & & & & & & & \\
\hline Human Dev. Index (HDI) & 0.189 & -0.847 & 1.000 & & & & & & & & & \\
\hline $\begin{array}{l}\text { Env. Perfor-mance Index } \\
\text { (EPI) }\end{array}$ & 0.319 & -0.665 & 0.864 & 1.000 & & & & & & & & \\
\hline Env. Sust. Index (ESI) & -0.027 & -0.408 & 0.432 & 0.587 & 1.000 & & & & & & & \\
\hline $\begin{array}{l}\text { Sustainable Society Index } \\
\text { (SSI) }\end{array}$ & 0.024 & -0.178 & 0.359 & 0.524 & 0.545 & 1.000 & & & & & & \\
\hline $\begin{array}{l}\text { Env. Vulnerabi-lity Index } \\
\text { (EVI) }\end{array}$ & -0.272 & 0.267 & -0.493 & -0.415 & 0.169 & -0.203 & 1.000 & & & & & \\
\hline $\begin{array}{l}\text { Sustainable Dev. Index } \\
\text { (SDI) }\end{array}$ & 0.197 & -0.793 & 0.919 & 0.886 & 0.534 & 0.485 & -0.428 & 1.000 & & & & \\
\hline Wellbeing Index (WI) & -0.017 & -0.534 & 0.650 & 0.717 & 0.655 & 0.586 & -0.179 & 0.749 & 1.000 & & & \\
\hline Happy Planet Index (HPI) & 0.583 & 0.043 & 0.210 & 0.314 & 0.049 & 0.135 & -0.332 & 0.221 & 0.077 & 1.000 & & \\
\hline $\begin{array}{l}\text { Quality of Life Index } \\
\text { (QOL) }\end{array}$ & -0.357 & -0.627 & 0.842 & 0.699 & 0.478 & 0.439 & -0.382 & 0.737 & 0.678 & 0.124 & 1.000 & \\
\hline $\begin{array}{l}\text { Eco. (Deficit) or Reserve } \\
\text { (gha. per capita) }\end{array}$ & -0.093 & 0.350 & -0.447 & -0.271 & 0.293 & 0.013 & 0.709 & -0.294 & -0.034 & -0.132 & -0.229 & 1.000 \\
\hline
\end{tabular}




\subsubsection{Limitations of the Present-day Distance From Quadrant the Approach}

The Present-day Distance From Quadrant approach provides a good snapshot of where in relation to the sustainability Quadrant countries are positioned today, but reveals nothing about the direction they are moving in. Thus, historical movement in relation to the Quadrant promises to yield more interesting results for researchers and policy-makers alike.

\subsection{Historical Movement Towards the Quadrant}

The purpose of this approach is to rank a country's performance based on the changes in its HDI and EF Index over time. Following the UNDP's approach for assessing the HDI's historical trends (UNDP, 2008), three time periods are considered here:

- Long-term: 1980 to 2005

- Medium-term: 1990 to 2005

- Short-term: 2000 to 2005

\subsubsection{Calculating Movement Towards the Quadrant}

In the HDI vs. EF Index plot used to represent the Global Sustainability Quadrant, there are four possible directions for 'movement' in time:

- Increase in $\mathrm{HDI}$ and increase in EF Index: $\quad+,+$

- Increase in $\mathrm{HDI}$ and decrease in EF Index: $\quad+,-$

- Decrease in $\mathrm{HDI}$ and increase in EF Index: $\quad-,+$

- Decrease in $\mathrm{HDI}$ and decrease in EF Index: - - -

Naturally, a country that exhibits $(+,+)$ movement is getting closer to the Quadrant, whereas a country that moves in the $(-,-)$ direction is moving away from it. The challenge when attempting to rank countries according to their performance in time lies in dealing with $(+,-)$ and $(-,+)$ movement, which depending on the magnitude of movement on each axis, could be moving closer to, or farther from, the Quadrant.

An approach ${ }^{21}$ similar to the shortest-distance (hypotenuse) method used to calculate presentday Distance From the Quadrant was considered, but it was eventually discarded in favor of a simple sum of movement on both axes. Still, the two approaches yielded very similar country rank lists (between them, a Pearson correlation coefficient close to 0.9 was found on all three time periods). Figure 4-7 illustrates the calculation method for a sample of four countries, each exhibiting movement in one of the four possible directions.

\footnotetext{
${ }^{21}$ The approach calculated the difference in distance from the ultimate goal of EF Index $=1$ and HDI = 1 on two distinct moments in time.
} 
Figure 4-7: Calculating Movement Towards the Quadrant

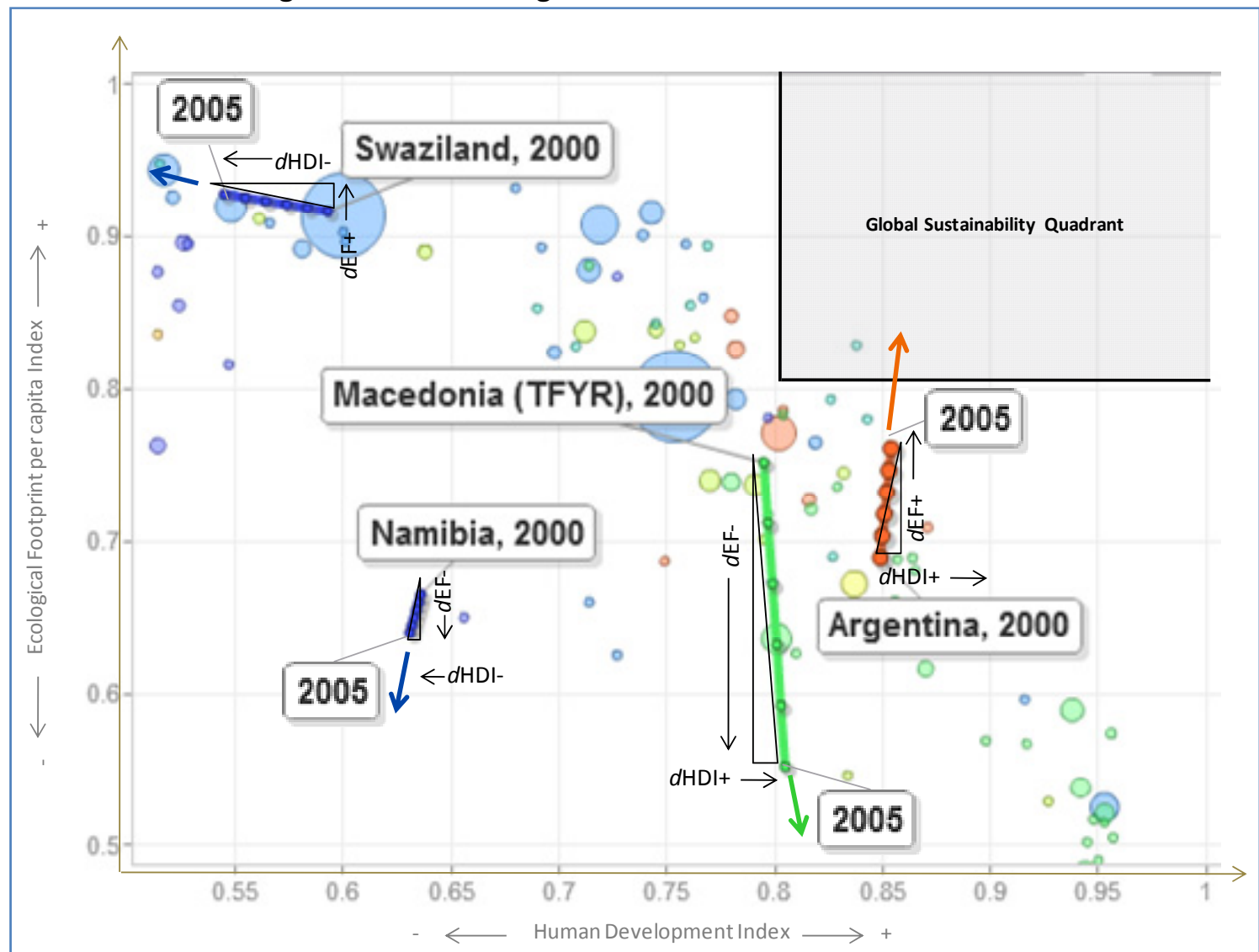

Sample calculation of Movement Towards the Quadrant:

Argentina (2000-2005): $\quad d \mathrm{HDI}=+0.005, \quad d \mathrm{EF}=+0.072, \quad$ Movement $=+0.077$

Macedonia (2000-2005): $\quad d \mathrm{HDI}=+0.010, \quad d \mathrm{EF}=-0.200, \quad$ Movement $=-0.190$

Namibia (2000-2005): $\quad d \mathrm{HDI}=-0.005, \quad d \mathrm{EF}=-0.025, \quad$ Movement $=-0.030$

Swaziland (2000-2005): $\quad d \mathrm{HDI}=-0.048, \quad d \mathrm{EF}=+0.011 \quad$ Movement $=-0.037$

Source: Created by the author using Google Motion Chart and MS Power Point. Data from: Global Footprint Network, 2008; UNDP, 2008.

\subsubsection{Limitations of the Movement Towards the Quadrant Approach}

This approach ultimately aims to identify attributes that mutually advance (or hinder) both requirements of sustainable development (high HDI and low EF) in a country. Now, a particular country may show most of its movement on the HDI axis, whereas another one may show movement of the same magnitude mostly on the EF axis, and yet, they will be regarded by this approach as showing equal progress in the direction of the Quadrant. If, for example, a reduction in meat consumption per capita was found to be correlated with Movement Towards the Quadrant; does this mean that it correlates with simultaneous progress on both dimensions? Or is it correlated with only one of them, so strongly, that it overshadows the other? Unfortunately, answering these questions is beyond the scope if this work. 


\subsubsection{Historical Movement Towards the Quadrant Country Rank Lists}

This section presents the country rank lists for historical movement on all three time periods analyzed. Unfortunately, historical HDI data for Cuba, the only country presently inside the Quadrant, is not available, so it could not be included in the analysis. Nevertheless, it is worth noting that Cuba's Ecological Footprint per capita is steadily increasing, so it very unlikely that it would have appeared among the top movers .

\subsubsection{Long-term}

The countries included in the long-term movement analysis are 69 , which is the number of countries where both Ecological Footprint and Human Development Index figures are available for both 1980 and 2005. Thus, they constitute the only countries where it now is possible to estimate long-term movement towards the Global Sustainability Quadrant. Table 4-4 ranks these countries from largest overall Movement Towards the Quadrant, to largest overall movement away from it.

Table 4-4: Long-term (1980 to 2005) Movement Towards the Quadrant - Country Rank List Note: Numbers in bold font on the Overall Movement column indicate $(+,+)$ movement. Numbers in parenthesis indicate negative movement.

Source: Created by the author. Data from: Global Footprint Network, 2008; UNDP, 2008.

\begin{tabular}{|l|c|c|c|c|}
\hline \multicolumn{1}{|c|}{ Country } & $\begin{array}{c}\text { Eco } \\
\text { Footprint } \\
\text { Index } \\
\text { Progress }\end{array}$ & $\begin{array}{c}\text { HDI } \\
\text { Progress }\end{array}$ & $\begin{array}{c}\text { Overall } \\
\text { Movement }\end{array}$ & Rank \\
\hline Norway & 0.328 & 0.067 & $\mathbf{0 . 3 9 5}$ & 1 \\
\hline Argentina & 0.231 & 0.064 & $\mathbf{0 . 2 9 5}$ & 2 \\
\hline Nepal & 0.017 & 0.213 & $\mathbf{0 . 2 3 0}$ & 3 \\
\hline Uruguay & 0.150 & 0.080 & $\mathbf{0 . 2 3 0}$ & 4 \\
\hline Germany & 0.148 & 0.072 & $\mathbf{0 . 2 2 0}$ & 5 \\
\hline Hungary & 0.145 & 0.072 & $\mathbf{0 . 2 1 7}$ & 6 \\
\hline United Arab Emirates & 0.057 & 0.158 & $\mathbf{0 . 2 1 5}$ & 7 \\
\hline Indonesia & 0.010 & 0.199 & $\mathbf{0 . 2 0 9}$ & 8 \\
\hline Trinidad and Tobago & 0.177 & 0.027 & $\mathbf{0 . 2 0 4}$ & 9 \\
\hline Egypt & $0.026)$ & 0.229 & 0.203 & 10 \\
\hline Bangladesh & 0.008 & 0.186 & $\mathbf{0 . 1 9 4}$ & 11 \\
\hline Finland & 0.097 & 0.086 & $\mathbf{0 . 1 8 3}$ & 12 \\
\hline Morocco & 0.010 & 0.167 & $\mathbf{0 . 1 7 7}$ & 13 \\
\hline Costa Rica & 0.092 & 0.083 & $\mathbf{0 . 1 7 5}$ & 14 \\
\hline Bolivia & 0.012 & 0.159 & $\mathbf{0 . 1 7 1}$ & 15 \\
\hline Swaziland & 0.169 & 0.000 & $\mathbf{0 . 1 6 9}$ & 16 \\
\hline Brazil & 0.050 & 0.118 & $\mathbf{0 . 1 6 8}$ & 17 \\
\hline & & & & \\
\hline
\end{tabular}


Table 4-4 (continued)

\begin{tabular}{|c|c|c|c|c|}
\hline Country & $\begin{array}{c}\text { Eco } \\
\text { Footprint } \\
\text { Index } \\
\text { Progress }\end{array}$ & $\begin{array}{c}\text { HDI } \\
\text { Progress }\end{array}$ & $\begin{array}{c}\text { Overall } \\
\text { Movement }\end{array}$ & Rank \\
\hline India & $(0.006)$ & 0.172 & 0.166 & 18 \\
\hline Guinea-Bissau & 0.030 & 0.134 & 0.164 & 19 \\
\hline Canada & 0.090 & 0.073 & 0.163 & 20 \\
\hline Paraguay & 0.086 & 0.076 & 0.162 & 21 \\
\hline Pakistan & $(0.001)$ & 0.162 & 0.161 & 22 \\
\hline Guatemala & $(0.003)$ & 0.161 & 0.158 & 23 \\
\hline France & 0.077 & 0.078 & 0.155 & 24 \\
\hline Syrian Arab Republic & 0.018 & 0.130 & 0.148 & 25 \\
\hline Burundi & 0.043 & 0.103 & 0.146 & 26 \\
\hline South Africa & 0.131 & 0.014 & 0.145 & 27 \\
\hline El Salvador & $(0.031)$ & 0.175 & 0.144 & 28 \\
\hline Turkey & $(0.026)$ & 0.168 & 0.142 & 29 \\
\hline China & $(0.090)$ & 0.225 & 0.135 & 30 \\
\hline Denmark & 0.066 & 0.068 & 0.134 & 31 \\
\hline Dominican Republic & 0.006 & 0.123 & 0.129 & 32 \\
\hline Benin & 0.016 & 0.105 & 0.121 & 33 \\
\hline Australia & 0.027 & 0.093 & 0.120 & 34 \\
\hline Netherlands & 0.050 & 0.069 & 0.119 & 35 \\
\hline Belgium & 0.038 & 0.076 & 0.114 & 36 \\
\hline Iran & $(0.100)$ & 0.211 & 0.111 & 37 \\
\hline Rwanda & 0.035 & 0.074 & 0.109 & 38 \\
\hline Peru & 0.012 & 0.095 & 0.107 & 39 \\
\hline Venezuela & 0.052 & 0.054 & 0.106 & 40 \\
\hline Haiti & 0.022 & 0.084 & 0.106 & 41 \\
\hline Philippines & 0.008 & 0.093 & 0.101 & 42 \\
\hline Malaysia & $(0.064)$ & 0.154 & 0.090 & 43 \\
\hline Singapore & $(0.043)$ & 0.132 & 0.089 & 44 \\
\hline Sri Lanka & $(0.005)$ & 0.092 & 0.087 & 45 \\
\hline Botswana & $(0.031)$ & 0.118 & 0.087 & 46 \\
\hline Switzerland & 0.029 & 0.057 & 0.086 & 47 \\
\hline Sweden & 0.008 & 0.075 & 0.083 & 48 \\
\hline Burkina Faso & $(0.022)$ & 0.103 & 0.081 & 49 \\
\hline Mozambique & $(0.001)$ & 0.080 & 0.079 & 50 \\
\hline Jordan & $(0.057)$ & 0.133 & 0.076 & 51 \\
\hline
\end{tabular}


Table 4-4 (continued)

\begin{tabular}{|l|c|c|c|c|}
\hline \multicolumn{1}{|c|}{ Country } & $\begin{array}{c}\text { Eco } \\
\text { Footprint } \\
\text { Index } \\
\text { Progress }\end{array}$ & $\begin{array}{c}\text { HDI } \\
\text { Progress }\end{array}$ & $\begin{array}{c}\text { Overall } \\
\text { Movement }\end{array}$ & Rank \\
\hline Ecuador & $(0.022)$ & 0.097 & 0.075 & 52 \\
\hline Austria & $(0.015)$ & 0.084 & 0.069 & 53 \\
\hline Chile & $(0.063)$ & 0.125 & 0.062 & 54 \\
\hline Panama & $(0.018)$ & 0.071 & 0.053 & 55 \\
\hline Thailand & $(0.089)$ & 0.138 & 0.049 & 56 \\
\hline Ireland & $(0.078)$ & 0.121 & 0.043 & 57 \\
\hline Italy & $(0.047)$ & 0.087 & 0.040 & 58 \\
\hline Central African Republic & 0.017 & 0.020 & $\mathbf{0 . 0 3 7}$ & 59 \\
\hline Mexico & $(0.056)$ & 0.089 & 0.033 & 60 \\
\hline United Kingdom & $(0.056)$ & 0.086 & 0.030 & 61 \\
\hline Portugal & $(0.150)$ & 0.134 & $(0.016)$ & 62 \\
\hline Japan & $(0.083)$ & 0.067 & $(0.016)$ & 63 \\
\hline New Zealand & $(0.112)$ & 0.083 & $(0.029)$ & 64 \\
\hline United States & $(0.095)$ & 0.058 & $(0.037)$ & 65 \\
\hline Spain & $(0.159)$ & 0.094 & $(0.065)$ & 66 \\
\hline Greece & $(0.210)$ & 0.092 & $(0.118)$ & 67 \\
\hline Israel & $(0.245)$ & 0.100 & $(0.145)$ & 68 \\
\hline Kuwait & $(0.724)$ & 0.103 & $(0.621)$ & 69 \\
\hline
\end{tabular}

Figure 4-8 illustrates, on the EF vs. HDI plot, how the top 5 performers in the period have moved closer to the Quadrant. In turn, Figure 4-9 illustrates how the bottom 5 performers have moved away from the Quadrant during the same period (1980 to 2005).

Notice that the 5 countries with the worst performance in the long term all show progress on the HDI; it is their drastically increasing ecological footprint what has taken them far away from the Sustainability Quadrant. 
Figure 4-8: Long-term (1980-2005) Movement Towards the Quadrant - Top 5 Performers

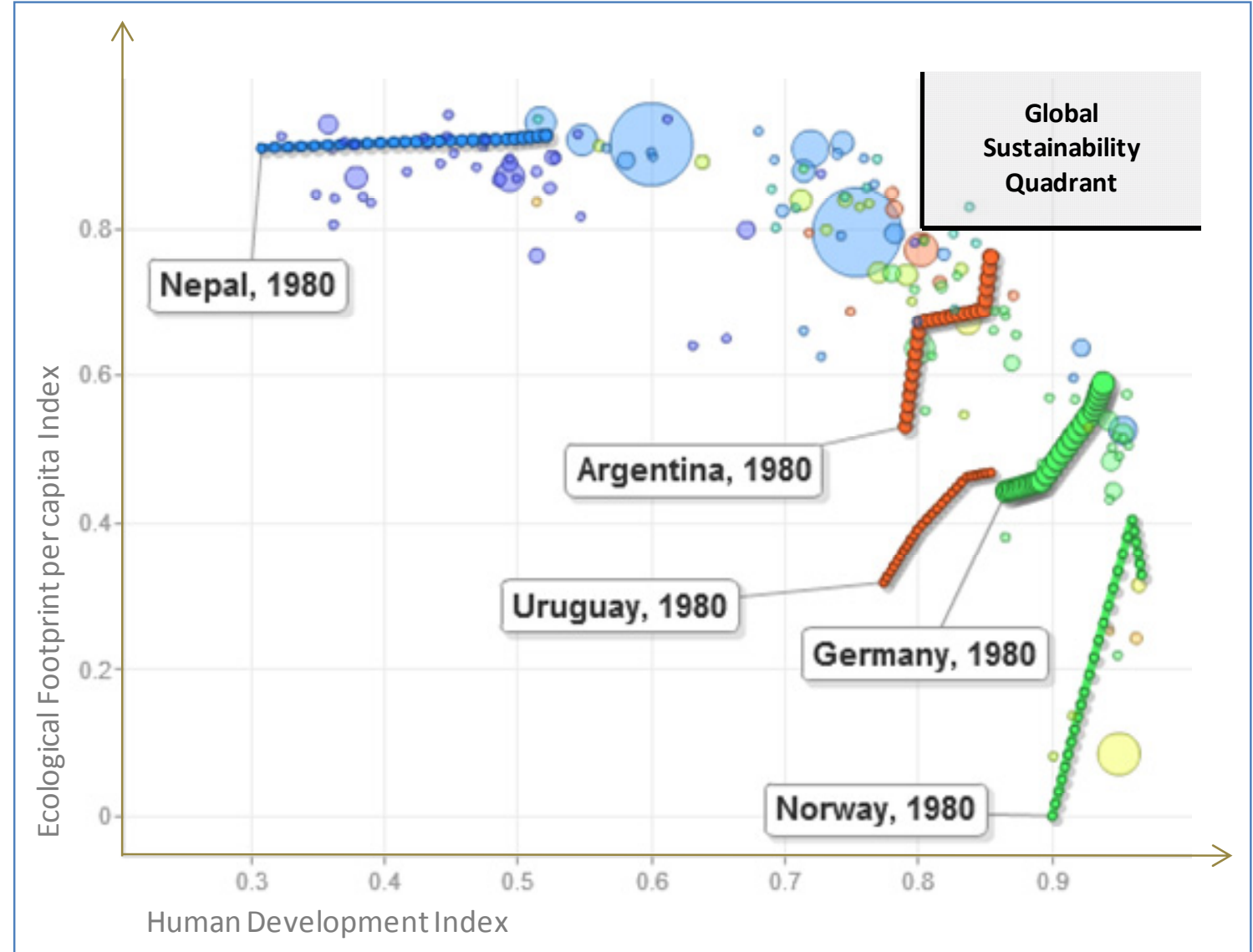

Note: The countries' labels point to the period's starting year; the last point along the progression represents the period's end year (2005).

Source: Created by the author using Google Motion Chart and MS Power Point. Data from: Global Footprint Network, 2008; UNDP, 2008. 
Figure 4-9: Long-term (1980-2005) Movement Towards the Quadrant - Bottom 5 Performers

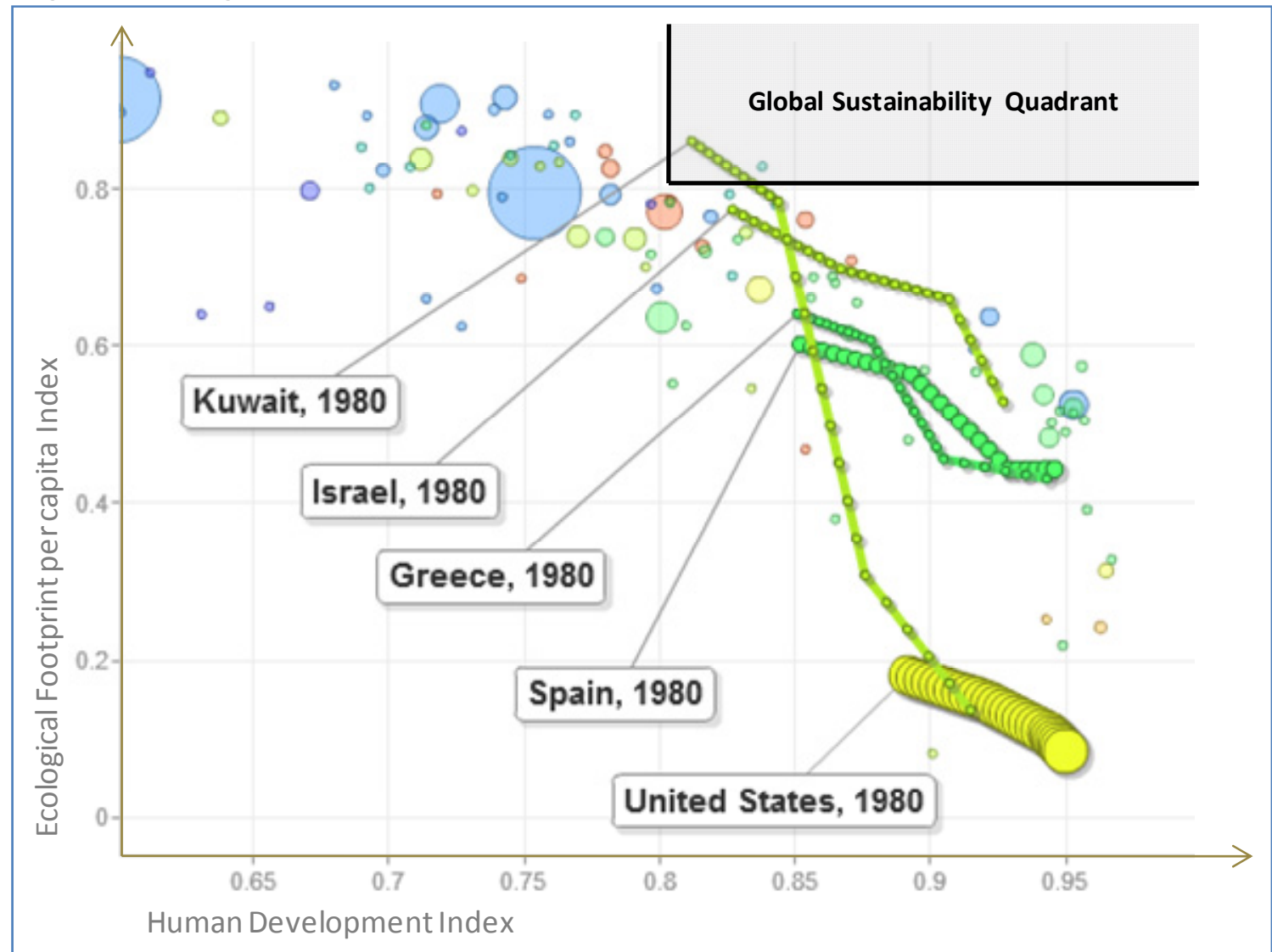

Note: The countries' labels point to the period's starting year; the last point along the progression represents the period's end year (2005).

Source: Created by the author using Google Motion Chart and MS Power Point. Data from: Global Footprint Network, 2008; UNDP, 2008.

Figure 4-10 is a world map where countries have been shaded according to their Long-term Movement Towards the Quadrant; darker shades indicate significant movement towards it (i.e., good performance over the period), whereas lighter shades indicate that the country is moving away from it. 
Figure 4-10: Long-term (1980-2005) Movement Towards the Quadrant World Map (quintiles)

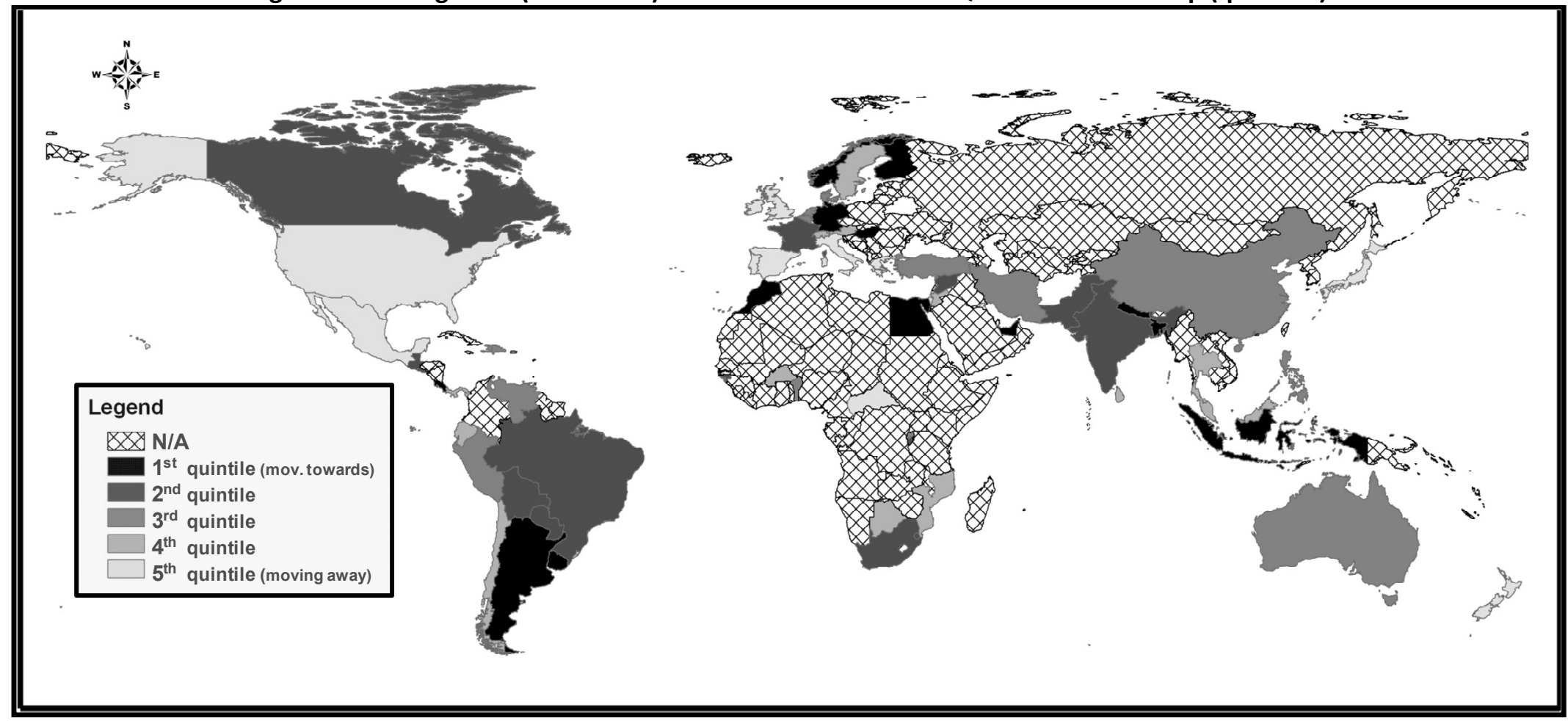

Source: Created by the author using ArcMap. Data from: Global Footprint Network, 2008; UNDP, 2008. World boundaries shapefile obtained from: DIVA-GIS, Thematic Mapping. World Countries Boundary File, World, 2002. Licensed under a Creative Commons Attribution 3.0 License. Downloaded from: http://finder.geocommons.com/overlays/5603 


\subsubsection{Medium-term}

The countries included in the medium-term movement analysis are 83, which is the number of countries where both Ecological Footprint and Human Development Index figures are available for both 1990 and 2005. Thus, they constitute the only countries where it is now possible to estimate medium-term movement towards the Global Sustainability Quadrant. Table 4-5 ranks these countries from largest overall Movement Towards the Quadrant to largest overall movement away from it.

Table 4-5: Medium-term (1990 to 2005) Movement Towards the Quadrant - Country Rank List Note: Numbers in bold font on the Overall Movement column indicate $(+,+)$ movement. Numbers in parenthesis indicate negative movement.

Source: Created by the author. Data from: Global Footprint Network, 2008; UNDP, 2008.

\begin{tabular}{|l|c|c|c|c|}
\hline \multicolumn{1}{|c|}{ Country } & $\begin{array}{c}\text { Eco } \\
\text { Footprint } \\
\text { Index } \\
\text { Progress }\end{array}$ & $\begin{array}{c}\text { HDI } \\
\text { Progress }\end{array}$ & $\begin{array}{c}\text { Overall } \\
\text { Movement }\end{array}$ & Rank \\
\hline Canada & 0.220 & 0.030 & $\mathbf{0 . 2 5 0}$ & 1 \\
\hline Singapore & 0.151 & 0.066 & $\mathbf{0 . 2 1 7}$ & 2 \\
\hline Norway & 0.159 & 0.043 & $\mathbf{0 . 2 0 2}$ & 3 \\
\hline Germany & 0.133 & 0.046 & $\mathbf{0 . 1 7 9}$ & 4 \\
\hline Romania & 0.124 & 0.037 & $\mathbf{0 . 1 6 1}$ & 5 \\
\hline Argentina & 0.089 & 0.053 & $\mathbf{0 . 1 4 2}$ & 6 \\
\hline Guinea-Bissau & 0.039 & 0.102 & $\mathbf{0 . 1 4 1}$ & 7 \\
\hline Guatemala & $(0.001)$ & 0.137 & 0.136 & 8 \\
\hline Hungary & 0.072 & 0.062 & $\mathbf{0 . 1 3 4}$ & 9 \\
\hline Tunisia & $(0.004)$ & 0.131 & 0.127 & 10 \\
\hline Bangladesh & $(0.003)$ & 0.127 & 0.124 & 11 \\
\hline Nepal & 0.009 & 0.114 & $\mathbf{0 . 1 2 3}$ & 12 \\
\hline Switzerland & 0.080 & 0.036 & $\mathbf{0 . 1 1 6}$ & 13 \\
\hline Egypt & $(0.025)$ & 0.140 & 0.115 & 14 \\
\hline Chile & 0.033 & 0.079 & $\mathbf{0 . 1 1 2}$ & 15 \\
\hline Morocco & $(0.011)$ & 0.122 & 0.111 & 16 \\
\hline Uganda & 0.028 & 0.082 & $\mathbf{0 . 1 1 0}$ & 17 \\
\hline Finland & 0.061 & 0.047 & $\mathbf{0 . 1 0 8}$ & 18 \\
\hline India & $(0.001)$ & 0.106 & 0.105 & 19 \\
\hline Rwanda & $(0.004)$ & 0.107 & 0.103 & 20 \\
\hline Indonesia & 0.007 & 0.096 & $\mathbf{0 . 1 0 3}$ & 21 \\
\hline Brazil & 0.009 & 0.094 & $\mathbf{0 . 1 0 3}$ & 22 \\
\hline Pakistan & $(0.005)$ & 0.105 & 0.100 & 23 \\
\hline Poland & 0.034 & 0.065 & $\mathbf{0 . 0 9 9}$ & 24 \\
\hline
\end{tabular}


Table 4-5 (continued)

\begin{tabular}{|c|c|c|c|c|}
\hline Country & $\begin{array}{c}\text { Eco } \\
\text { Footprint } \\
\text { Index } \\
\text { Progress } \\
\end{array}$ & $\begin{array}{c}\text { HDI } \\
\text { Progress }\end{array}$ & $\begin{array}{c}\text { Overall } \\
\text { Movement }\end{array}$ & Rank \\
\hline Bolivia & 0.008 & 0.091 & 0.099 & 25 \\
\hline Netherlands & 0.051 & 0.040 & 0.091 & 26 \\
\hline Costa Rica & 0.035 & 0.055 & 0.090 & 27 \\
\hline Colombia & 0.008 & 0.079 & 0.087 & 28 \\
\hline Belgium & 0.044 & 0.043 & 0.087 & 29 \\
\hline Paraguay & 0.044 & 0.042 & 0.086 & 30 \\
\hline Mozambique & $(0.003)$ & 0.087 & 0.084 & 31 \\
\hline Malawi & 0.021 & 0.062 & 0.083 & 32 \\
\hline Senegal & $(0.001)$ & 0.082 & 0.081 & 33 \\
\hline Benin & 0.007 & 0.074 & 0.081 & 34 \\
\hline Algeria & $(0.019)$ & 0.100 & 0.081 & 35 \\
\hline Haiti & 0.007 & 0.073 & 0.080 & 36 \\
\hline Dominican Republic & $(0.018)$ & 0.097 & 0.079 & 37 \\
\hline China & $(0.070)$ & 0.147 & 0.077 & 38 \\
\hline South Africa & 0.103 & $(0.027)$ & 0.076 & 39 \\
\hline Myanmar & $(0.022)$ & 0.096 & 0.074 & 40 \\
\hline Syrian Arab Republic & $(0.035)$ & 0.106 & 0.071 & 41 \\
\hline Tanzania & 0.013 & 0.058 & 0.071 & 42 \\
\hline Turkey & $(0.020)$ & 0.091 & 0.071 & 43 \\
\hline Philippines & 0.016 & 0.049 & 0.065 & 44 \\
\hline Denmark & 0.013 & 0.051 & 0.064 & 45 \\
\hline Burundi & 0.017 & 0.044 & 0.061 & 46 \\
\hline Viet Nam & $(0.057)$ & 0.117 & 0.060 & 47 \\
\hline El Salvador & $(0.031)$ & 0.090 & 0.059 & 48 \\
\hline France & 0.012 & 0.045 & 0.057 & 49 \\
\hline Congo & 0.029 & 0.027 & 0.056 & 50 \\
\hline Ireland & $(0.026)$ & 0.081 & 0.055 & 51 \\
\hline Venezuela & 0.022 & 0.029 & 0.051 & 52 \\
\hline Peru & $(0.024)$ & 0.074 & 0.050 & 53 \\
\hline United Kingdom & $(0.010)$ & 0.056 & 0.046 & 54 \\
\hline United Arab Emirates & $(0.022)$ & 0.067 & 0.045 & 55 \\
\hline Ecuador & $(0.019)$ & 0.064 & 0.045 & 56 \\
\hline Burkina Faso & $(0.023)$ & 0.064 & 0.041 & 57 \\
\hline Sri Lanka & $(0.016)$ & 0.055 & 0.039 & 58 \\
\hline
\end{tabular}


Table 4-5 (continued)

\begin{tabular}{|l|c|c|c|c|}
\hline \multicolumn{1}{|c|}{ Country } & $\begin{array}{c}\text { Eco } \\
\text { Footprint } \\
\text { Index } \\
\text { Progress }\end{array}$ & $\begin{array}{c}\text { HDI } \\
\text { Progress }\end{array}$ & $\begin{array}{c}\text { Overall } \\
\text { Movement }\end{array}$ & Rank \\
\hline Nigeria & $(0.004)$ & 0.042 & 0.038 & 59 \\
\hline Thailand & $(0.054)$ & 0.090 & 0.036 & 60 \\
\hline Australia & $(0.031)$ & 0.063 & 0.032 & 61 \\
\hline Italy & $(0.024)$ & 0.056 & 0.032 & 62 \\
\hline Japan & $(0.009)$ & 0.037 & 0.028 & 63 \\
\hline Saudi Arabia & $(0.063)$ & 0.090 & 0.027 & 64 \\
\hline Malaysia & $(0.064)$ & 0.083 & 0.019 & 65 \\
\hline Iran & $(0.082)$ & 0.099 & 0.017 & 66 \\
\hline Portugal & $(0.054)$ & 0.069 & 0.015 & 67 \\
\hline Côte d'Ivoire & 0.017 & $(0.010)$ & 0.007 & 68 \\
\hline Austria & $(0.043)$ & 0.050 & 0.007 & 69 \\
\hline Swaziland & 0.072 & $(0.072)$ & $(0.000)$ & 70 \\
\hline Mexico & $(0.068)$ & 0.064 & $(0.004)$ & 71 \\
\hline Panama & $(0.073)$ & 0.064 & $(0.009)$ & 72 \\
\hline Central African Republic & 0.008 & $(0.018)$ & $(0.010)$ & 73 \\
\hline Mauritius & $(0.092)$ & 0.080 & $(0.012)$ & 74 \\
\hline Zambia & 0.016 & $(0.034)$ & $(0.018)$ & 75 \\
\hline Sweden & $(0.083)$ & 0.053 & $(0.030)$ & 76 \\
\hline United States & $(0.065)$ & 0.030 & $(0.035)$ & 77 \\
\hline New Zealand & $(0.098)$ & 0.062 & $(0.036)$ & 78 \\
\hline Spain & $(0.121)$ & 0.053 & $(0.068)$ & 79 \\
\hline Trinidad and Tobago & $(0.115)$ & 0.029 & $(0.086)$ & 80 \\
\hline Botswana & $(0.067)$ & $(0.024)$ & $(0.091)$ & 81 \\
\hline Greece & $(0.177)$ & 0.065 & $(0.112)$ & 82 \\
\hline Namibia & $(0.121)$ & $(0.022)$ & $(0.143)$ & 83 \\
\hline & & & & \\
\hline
\end{tabular}

Figure 4-11 illustrates, on the EF vs. HDI plot, how the top 5 performers in the period have moved closer to the Quadrant. In turn, Figure 4-12 illustrates how the bottom 5 performers have moved away from the Quadrant during the same period (1990 to 2005). 
Figure 4-11: Medium-term (1990-2005) Movement Towards the Quadrant - Top 5 Performers

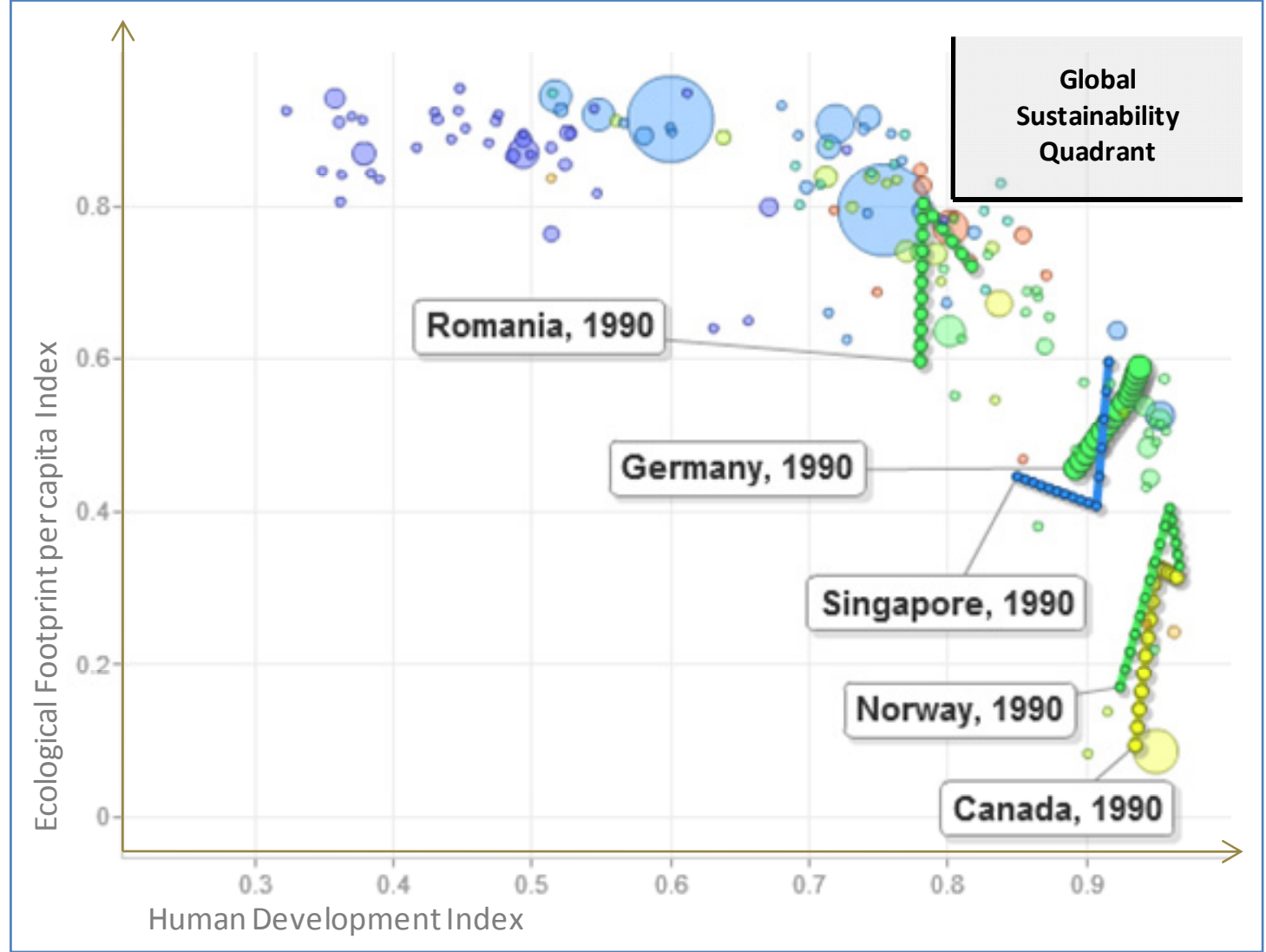

Note: The countries' labels point to the period's starting year; the last point along the progression represents the period's end year (2005).

Source: Created by the author using Google Motion Chart and MS Power Point. Data from: Global Footprint Network, 2008; UNDP, 2008.

In Figure 4-11, notice that 3 of the top 5 performers (Romania, Norway, and Canada) in the medium term have actually reversed their positive movement in the last 5 years (by increasing their Ecological Footprint). 
Figure 4-12: Medium-term (1990-2005) Movement Towards the Quadrant - Bottom 5 Performers

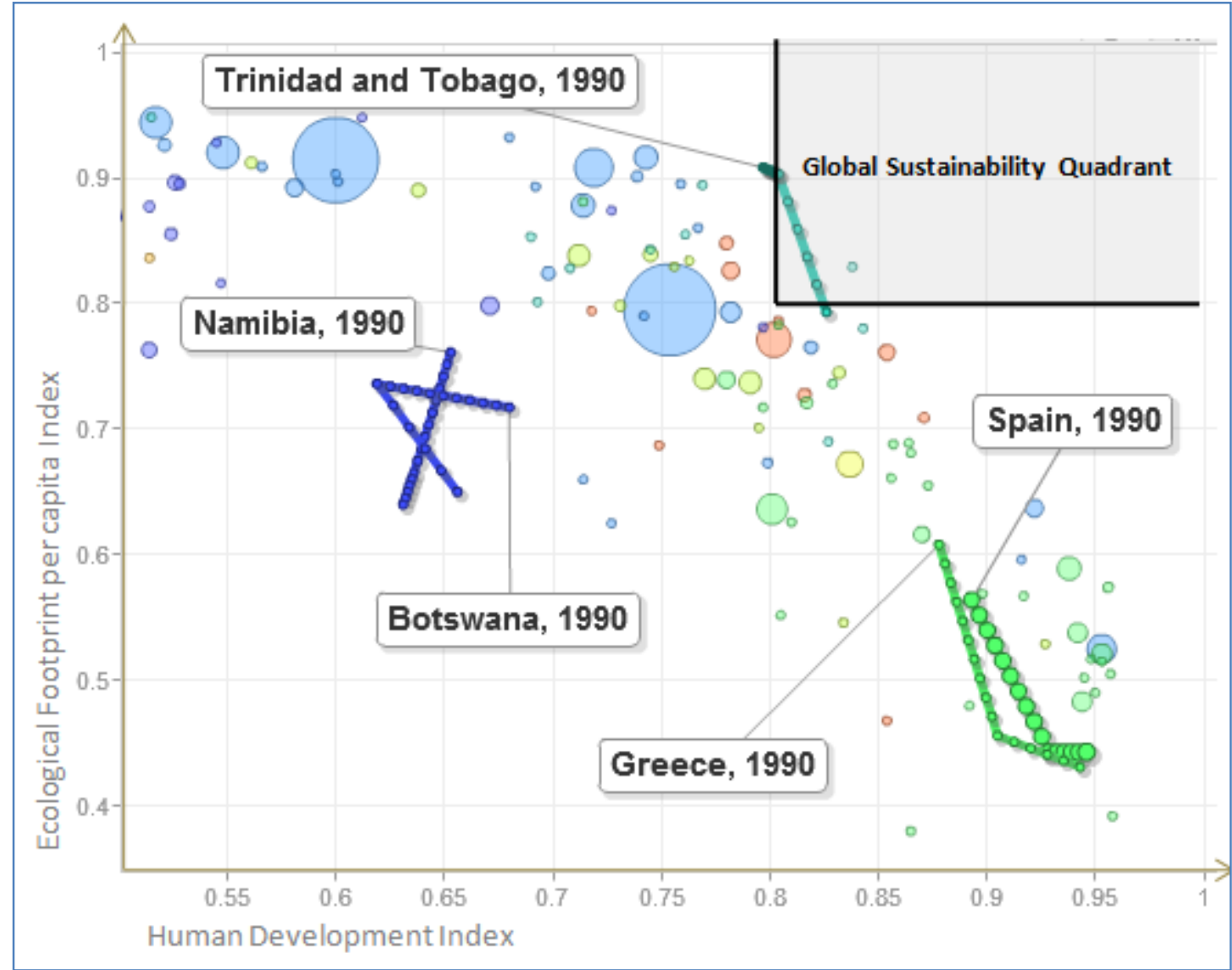

Note: The countries' labels point to the period's starting year; the last point along the progression represents the period's end year (2005).

Source: Created by the author using Google Motion Chart and MS Power Point. Data from: Global Footprint Network, 2008; UNDP, 2008.

In Figure 4-12, notice Trinidad and Tobago's brief stint across the Quadrant; its increasing EF has taken it just outside it after 2004. Botswana's movement is also interesting, first moving in the $(-,+)$ direction, and then completely reversing movement into the $(+,-)$ direction, but moving away from the Quadrant overall.

Figure 4-13 is a world map where countries have been shaded according to their Medium-term Movement Towards the Quadrant; darker shades indicate significant movement towards it (i.e., good performance over the period), whereas lighter shades indicate that the country is moving away from it. 
Figure 4-13: Medium-term (1990-2005) Movement Towards the Quadrant World Map (quintiles)

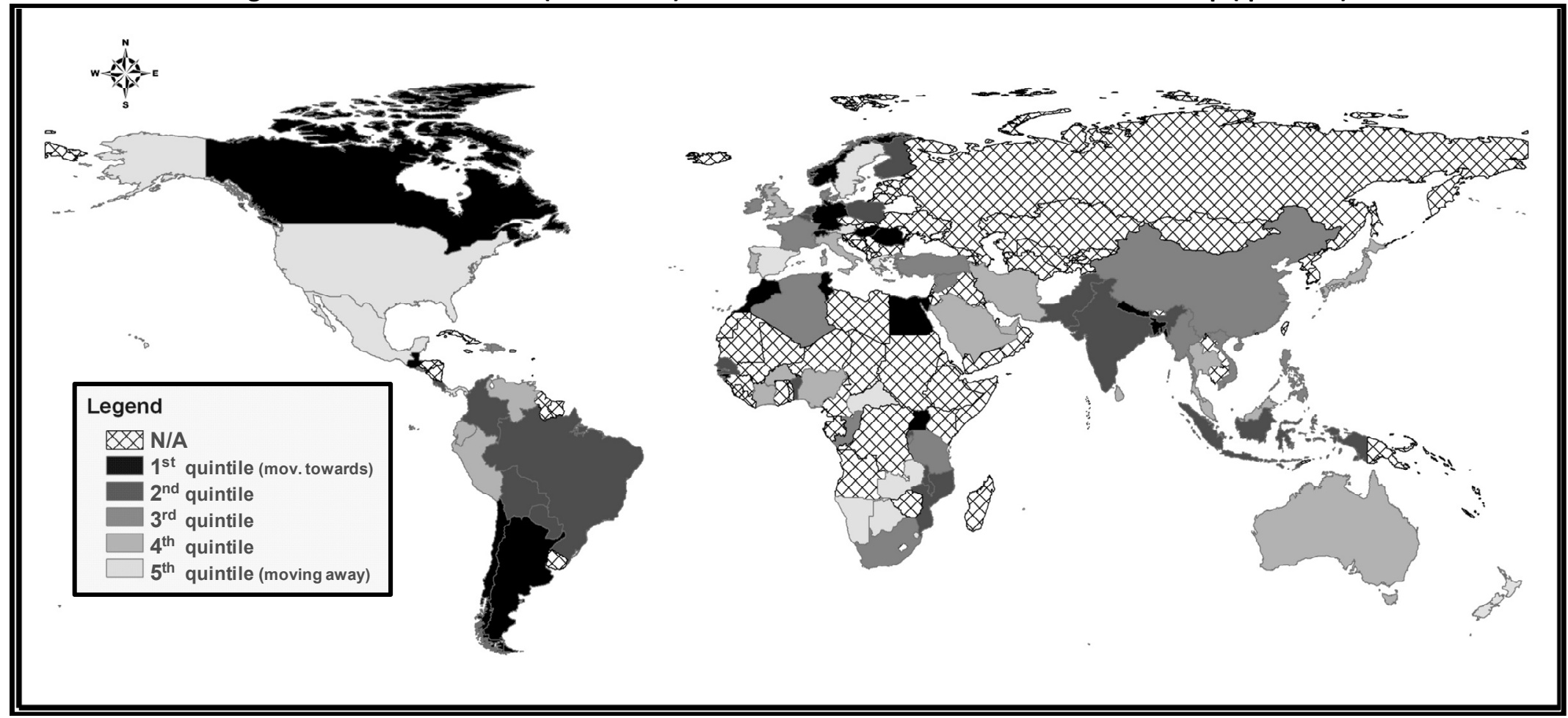

Source: Created by the author using ArcMap. Data from: Global Footprint Network, 2008; UNDP, 2008. World boundaries shapefile obtained from: DIVA-GIS, Thematic Mapping. World Countries Boundary File, World, 2002. Licensed under a Creative Commons Attribution 3.0 License. Downloaded from: http://finder.geocommons.com/overlays/5603 


\subsubsection{Short-term}

The countries included in the short-term movement analysis are 121, which is the number of countries where both Ecological Footprint and Human Development Index figures are available for both 2000 and 2005. Thus, they constitute the only countries where it is now possible to estimate short-term movement towards the Global Sustainability Quadrant. Table 4-6 ranks these countries from largest overall Movement Towards the Quadrant to largest overall movement away from it. Numbers in bold font on the Overall Movement column indicate $(+,+)$ movement.

Table 4-6: Short-term (2000 to 2005) Movement Towards the Quadrant - Country Rank List Note: Numbers in bold font on the Overall Movement column indicate $(+,+)$ movement. Numbers in parenthesis indicate negative movement.

Source: Created by the author. Data from: Global Footprint Network, 2008; UNDP, 2008.

\begin{tabular}{|l|c|c|c|c|}
\hline \multicolumn{1}{|c|}{ Country } & $\begin{array}{c}\text { Eco } \\
\text { Footprint } \\
\text { Index } \\
\text { Progress }\end{array}$ & $\begin{array}{c}\text { HDI } \\
\text { Progress }\end{array}$ & $\begin{array}{c}\text { Overall } \\
\text { Movement }\end{array}$ & Rank \\
\hline Singapore & 0.189 & 0.009 & $\mathbf{0 . 1 9 8}$ & 1 \\
\hline Mongolia & 0.115 & 0.038 & $\mathbf{0 . 1 5 3}$ & 2 \\
\hline Kyrgyzstan & 0.099 & 0.013 & $\mathbf{0 . 1 1 2}$ & 3 \\
\hline Portugal & 0.061 & 0.019 & $\mathbf{0 . 0 8 0}$ & 4 \\
\hline Argentina & 0.072 & 0.005 & $\mathbf{0 . 0 7 7}$ & 5 \\
\hline Congo & 0.017 & 0.052 & $\mathbf{0 . 0 6 9}$ & 6 \\
\hline Paraguay & 0.053 & 0.015 & $\mathbf{0 . 0 6 8}$ & 7 \\
\hline Tunisia & $(0.013)$ & 0.079 & 0.066 & 8 \\
\hline Netherlands & 0.057 & 0.007 & $\mathbf{0 . 0 6 4}$ & 9 \\
\hline Yemen & $(0.002)$ & 0.064 & 0.062 & 10 \\
\hline Nigeria & 0.017 & 0.044 & $\mathbf{0 . 0 6 1}$ & 11 \\
\hline United Arab Emirates & 0.009 & 0.049 & $\mathbf{0 . 0 5 8}$ & 12 \\
\hline Niger & $(0.013)$ & 0.070 & 0.057 & 13 \\
\hline Costa Rica & 0.037 & 0.019 & $\mathbf{0 . 0 5 6}$ & 14 \\
\hline Laos & 0.017 & 0.038 & $\mathbf{0 . 0 5 5}$ & 15 \\
\hline Indonesia & 0.007 & 0.048 & $\mathbf{0 . 0 5 5}$ & 16 \\
\hline Cambodia & $(0.001)$ & 0.055 & 0.054 & 17 \\
\hline Tanzania & 0.004 & 0.049 & $\mathbf{0 . 0 5 3}$ & 18 \\
\hline Brazil & 0.040 & 0.013 & $\mathbf{0 . 0 5 3}$ & 19 \\
\hline Guinea-Bissau & 0.017 & 0.035 & $\mathbf{0 . 0 5 2}$ & 20 \\
\hline Ethiopia & $(0.006)$ & 0.056 & 0.050 & 21 \\
\hline Rwanda & 0.006 & 0.044 & $\mathbf{0 . 0 5 0}$ & 22 \\
\hline Madagascar & 0.019 & 0.030 & $\mathbf{0 . 0 4 9}$ & 23 \\
\hline Mauritania & 0.021 & 0.027 & $\mathbf{0 . 0 4 8}$ & 24 \\
\hline & & & & \\
\hline
\end{tabular}


Table 4-6 (continued)

\begin{tabular}{|c|c|c|c|c|}
\hline Country & $\begin{array}{c}\text { Eco } \\
\text { Footprint } \\
\text { Index } \\
\text { Progress }\end{array}$ & $\begin{array}{c}\text { HDI } \\
\text { Progress }\end{array}$ & $\begin{array}{c}\text { Overall } \\
\text { Movement }\end{array}$ & Rank \\
\hline France & 0.035 & 0.013 & 0.048 & 25 \\
\hline Morocco & $(0.012)$ & 0.056 & 0.044 & 26 \\
\hline Uganda & 0.011 & 0.033 & 0.044 & 27 \\
\hline Germany & 0.036 & 0.007 & 0.043 & 28 \\
\hline Mali & 0.000 & 0.041 & 0.041 & 29 \\
\hline India & 0.002 & 0.039 & 0.041 & 30 \\
\hline Benin & 0.012 & 0.028 & 0.040 & 31 \\
\hline Nicaragua & 0.013 & 0.027 & 0.040 & 32 \\
\hline Switzerland & 0.031 & 0.008 & 0.039 & 33 \\
\hline Turkey & 0.002 & 0.037 & 0.039 & 34 \\
\hline Senegal & 0.012 & 0.026 & 0.038 & 35 \\
\hline El Salvador & $(0.002)$ & 0.038 & 0.036 & 36 \\
\hline Zambia & $(0.001)$ & 0.037 & 0.036 & 37 \\
\hline Myanmar & 0.006 & 0.030 & 0.036 & 38 \\
\hline Philippines & 0.017 & 0.018 & 0.035 & 39 \\
\hline Honduras & 0.003 & 0.031 & 0.034 & 40 \\
\hline Nepal & 0.005 & 0.029 & 0.034 & 41 \\
\hline Guatemala & 0.005 & 0.028 & 0.033 & 42 \\
\hline Venezuela & 0.017 & 0.015 & 0.032 & 43 \\
\hline Malaysia & 0.010 & 0.022 & 0.032 & 44 \\
\hline Congo (Democratic Rep.) & 0.008 & 0.023 & 0.031 & 45 \\
\hline Bolivia & 0.010 & 0.021 & 0.031 & 46 \\
\hline Dominican Republic & 0.014 & 0.017 & 0.031 & 47 \\
\hline Chad & $(0.002)$ & 0.032 & 0.030 & 48 \\
\hline Bangladesh & 0.002 & 0.028 & 0.030 & 49 \\
\hline Mauritius & 0.002 & 0.028 & 0.030 & 49 \\
\hline Egypt & $(0.017)$ & 0.047 & 0.030 & 51 \\
\hline Tajikistan & $(0.003)$ & 0.032 & 0.029 & 52 \\
\hline Colombia & 0.007 & 0.022 & 0.029 & 53 \\
\hline Uzbekistan & 0.012 & 0.016 & 0.028 & 54 \\
\hline Malawi & 0.022 & 0.003 & 0.025 & 55 \\
\hline New Zealand & 0.009 & 0.016 & 0.025 & 56 \\
\hline Uruguay & 0.006 & 0.018 & 0.024 & 57 \\
\hline Australia & 0.011 & 0.012 & 0.023 & 58 \\
\hline
\end{tabular}


Table 4-6 (continued)

\begin{tabular}{|c|c|c|c|c|}
\hline Country & $\begin{array}{c}\text { Eco } \\
\text { Footprint } \\
\text { Index } \\
\text { Progress } \\
\end{array}$ & $\begin{array}{c}\text { HDI } \\
\text { Progress }\end{array}$ & $\begin{array}{c}\text { Overall } \\
\text { Movement }\end{array}$ & Rank \\
\hline Burkina Faso & $(0.023)$ & 0.045 & 0.022 & 59 \\
\hline Angola & $(0.003)$ & 0.024 & 0.021 & 60 \\
\hline Chile & $(0.002)$ & 0.023 & 0.021 & 61 \\
\hline Poland & 0.000 & 0.018 & 0.018 & 62 \\
\hline Kenya & 0.008 & 0.010 & 0.018 & 63 \\
\hline Spain & 0.000 & 0.017 & 0.017 & 64 \\
\hline Côte d'Ivoire & 0.016 & $(0.001)$ & 0.015 & 65 \\
\hline Greece & $(0.025)$ & 0.038 & 0.013 & 66 \\
\hline Ireland & $(0.014)$ & 0.024 & 0.010 & 67 \\
\hline Burundi & $(0.008)$ & 0.018 & 0.010 & 68 \\
\hline Italy & $(0.007)$ & 0.017 & 0.010 & 69 \\
\hline Lithuania & $(0.024)$ & 0.034 & 0.010 & 70 \\
\hline Mozambique & $(0.018)$ & 0.028 & 0.010 & 71 \\
\hline Jamaica & $(0.012)$ & 0.020 & 0.008 & 72 \\
\hline Algeria & $(0.025)$ & 0.033 & 0.008 & 73 \\
\hline Bulgaria & $(0.019)$ & 0.027 & 0.008 & 74 \\
\hline Sri Lanka & $(0.009)$ & 0.016 & 0.007 & 75 \\
\hline Cameroon & 0.000 & 0.006 & 0.006 & 76 \\
\hline Croatia & $(0.021)$ & 0.027 & 0.006 & 77 \\
\hline Latvia & $(0.035)$ & 0.039 & 0.004 & 78 \\
\hline Moldova & (0.031) & 0.035 & 0.004 & 79 \\
\hline Belarus & $(0.023)$ & 0.025 & 0.002 & 80 \\
\hline Togo & 0.002 & $(0.001)$ & 0.001 & 81 \\
\hline Armenia & $(0.031)$ & 0.032 & 0.001 & 82 \\
\hline Ghana & $(0.026)$ & 0.027 & 0.001 & 83 \\
\hline Canada & $(0.016)$ & 0.015 & $(0.001)$ & 84 \\
\hline Japan & $(0.016)$ & 0.012 & $(0.004)$ & 85 \\
\hline South Africa & 0.012 & $(0.016)$ & $(0.004)$ & 86 \\
\hline Sudan & $(0.030)$ & 0.025 & $(0.005)$ & 87 \\
\hline Finland & $(0.017)$ & 0.012 & $(0.005)$ & 88 \\
\hline Azerbaijan & $(0.044)$ & 0.037 & $(0.007)$ & 89 \\
\hline China & $(0.043)$ & 0.036 & $(0.007)$ & 90 \\
\hline Thailand & $(0.040)$ & 0.032 & $(0.008)$ & 91 \\
\hline Central African Republic & 0.007 & $(0.016)$ & $(0.009)$ & 92 \\
\hline
\end{tabular}


Table 4-6 (continued)

\begin{tabular}{|c|c|c|c|c|}
\hline Country & $\begin{array}{c}\text { Eco } \\
\text { Footprint } \\
\text { Index } \\
\text { Progress } \\
\end{array}$ & $\begin{array}{c}\text { HDI } \\
\text { Progress }\end{array}$ & $\begin{array}{c}\text { Overall } \\
\text { Movement }\end{array}$ & Rank \\
\hline Hungary & $(0.040)$ & 0.030 & $(0.010)$ & 93 \\
\hline Viet Nam & $(0.036)$ & 0.026 & $(0.010)$ & 94 \\
\hline Iran & $(0.048)$ & 0.035 & $(0.013)$ & 95 \\
\hline Estonia & $(0.046)$ & 0.032 & $(0.014)$ & 96 \\
\hline United Kingdom & $(0.029)$ & 0.015 & $(0.014)$ & 97 \\
\hline United States & $(0.021)$ & 0.006 & $(0.015)$ & 98 \\
\hline Austria & $(0.024)$ & 0.008 & $(0.016)$ & 99 \\
\hline Denmark & $(0.030)$ & 0.013 & $(0.017)$ & 100 \\
\hline Albania & $(0.046)$ & 0.027 & $(0.019)$ & 101 \\
\hline Gabon & $(0.039)$ & 0.018 & $(0.021)$ & 102 \\
\hline Belgium & $(0.023)$ & 0.002 & $(0.021)$ & 103 \\
\hline Syrian Arab Republic & $(0.039)$ & 0.017 & $(0.022)$ & 104 \\
\hline Georgia & $(0.050)$ & 0.026 & $(0.024)$ & 105 \\
\hline Panama & $(0.042)$ & 0.018 & $(0.024)$ & 106 \\
\hline Namibia & $(0.025)$ & $(0.005)$ & $(0.030)$ & 107 \\
\hline Swaziland & 0.011 & $(0.048)$ & $(0.037)$ & 108 \\
\hline Ukraine & $(0.068)$ & 0.027 & $(0.041)$ & 109 \\
\hline Czech Republic & $(0.067)$ & 0.025 & $(0.042)$ & 110 \\
\hline Slovenia & $(0.066)$ & 0.024 & $(0.042)$ & 111 \\
\hline Lesotho & $(0.009)$ & $(0.035)$ & $(0.044)$ & 112 \\
\hline Romania & $(0.082)$ & 0.035 & $(0.047)$ & 113 \\
\hline Botswana & $(0.086)$ & 0.037 & $(0.049)$ & 114 \\
\hline Slovakia & $(0.076)$ & 0.026 & $(0.050)$ & 115 \\
\hline Norway & $(0.076)$ & 0.007 & $(0.069)$ & 116 \\
\hline Trinidad and Tobago & $(0.110)$ & 0.022 & $(0.088)$ & 117 \\
\hline Kazakhstan & $(0.170)$ & 0.053 & $(0.117)$ & 118 \\
\hline Sweden & $(0.133)$ & 0.005 & $(0.128)$ & 119 \\
\hline Kuwait & $(0.171)$ & 0.039 & $(0.132)$ & 120 \\
\hline Macedonia (TFYR) & $(0.200)$ & 0.010 & $(0.190)$ & 121 \\
\hline
\end{tabular}

Figure 4-14 illustrates, on the EF vs. HDI plot, how the top 5 performers in the period have moved closer to the Quadrant. In turn, Figure 4-15 illustrates how the bottom 5 performers have moved away from the Quadrant during the same period (2000 to 2005). 
Figure 4-14: Short-term (2000-2005) Movement Towards the Quadrant - Top 5 Performers

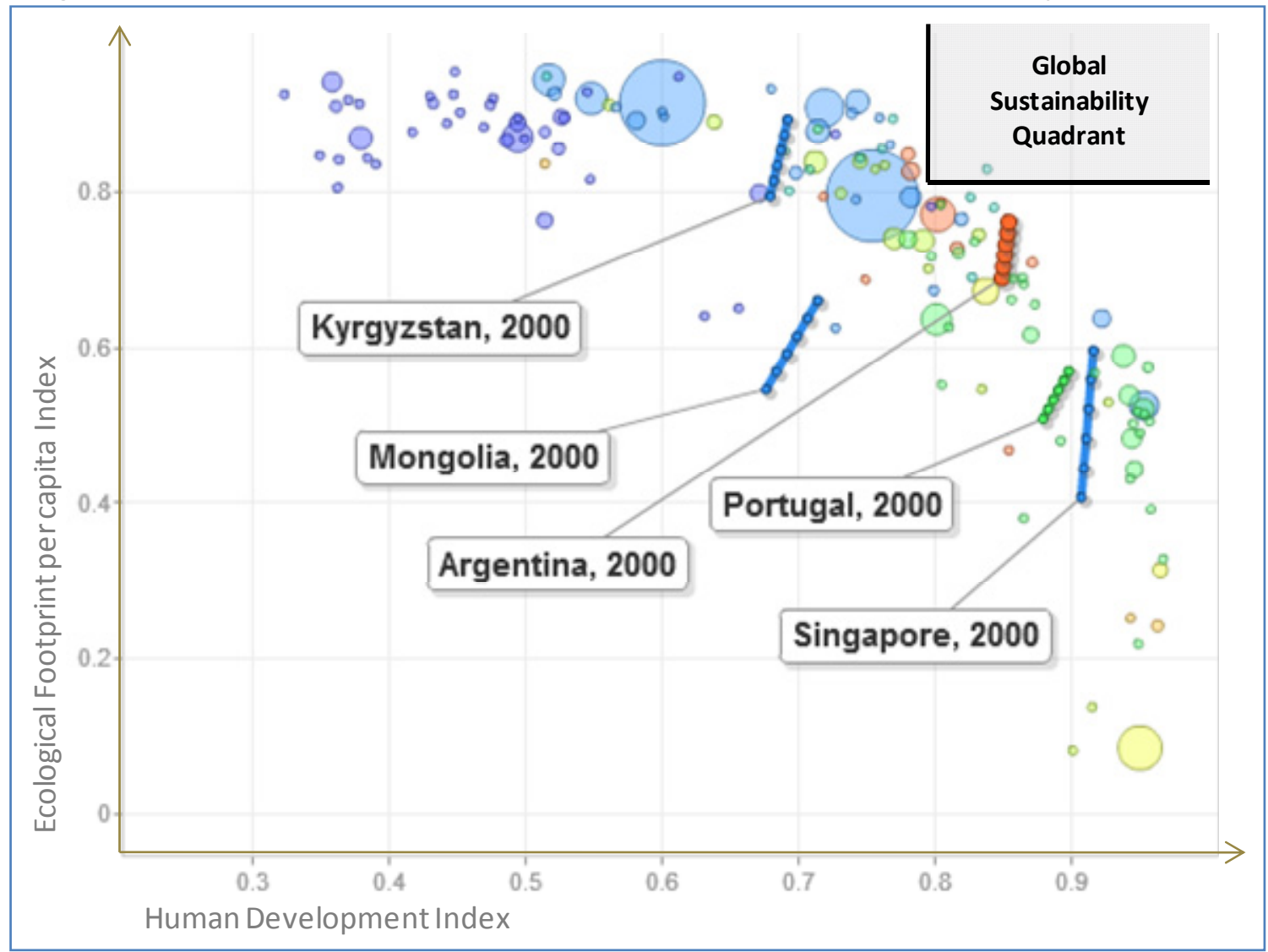

Note: The countries' labels point to the period's starting year; the last point along the progression represents the period's end year (2005).

Source: Created by the author using Google Motion Chart and MS Power Point. Data from: Global Footprint Network, 2008; UNDP, 2008. 
Figure 4-15: Short-term (2000-2005) Movement Towards the Quadrant - Bottom 5 Performers

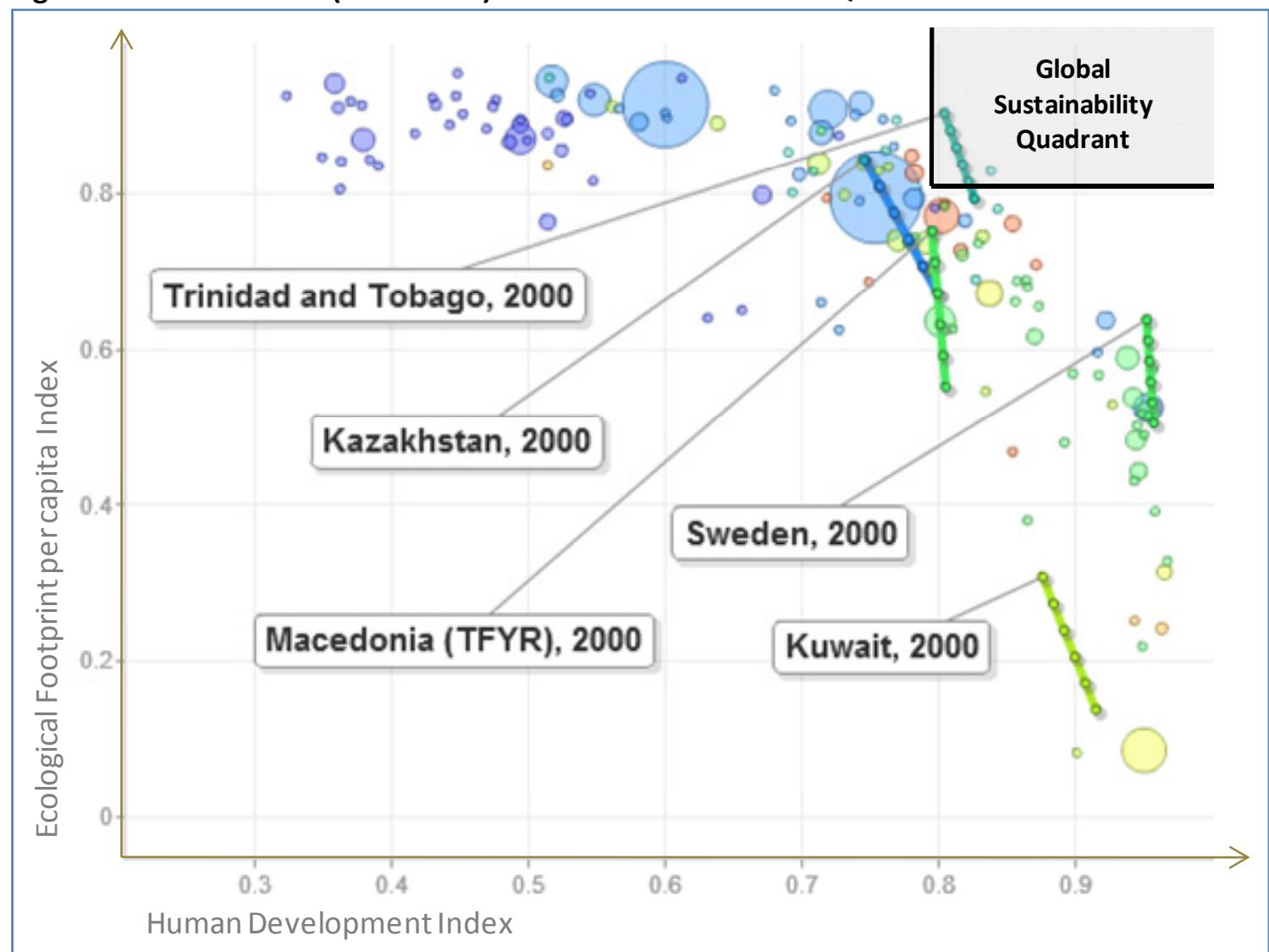

Note: The countries' labels point to the period's starting year; the last point along the progression represents the period's end year (2005).

Source: Created by the author using Google Motion Chart and MS Power Point. Data from: Global Footprint Network, 2008; UNDP, 2008.

Figure 4-16 is a world map where countries have been shaded according to their Short-term Movement Towards the Quadrant; darker shades indicate significant movement towards it (i.e., good performance over the period), whereas lighter shades indicate that the country is moving away from it. 
Figure 4-16: Short-term (2000-2005) Movement Towards the Quadrant World Map (quintiles)

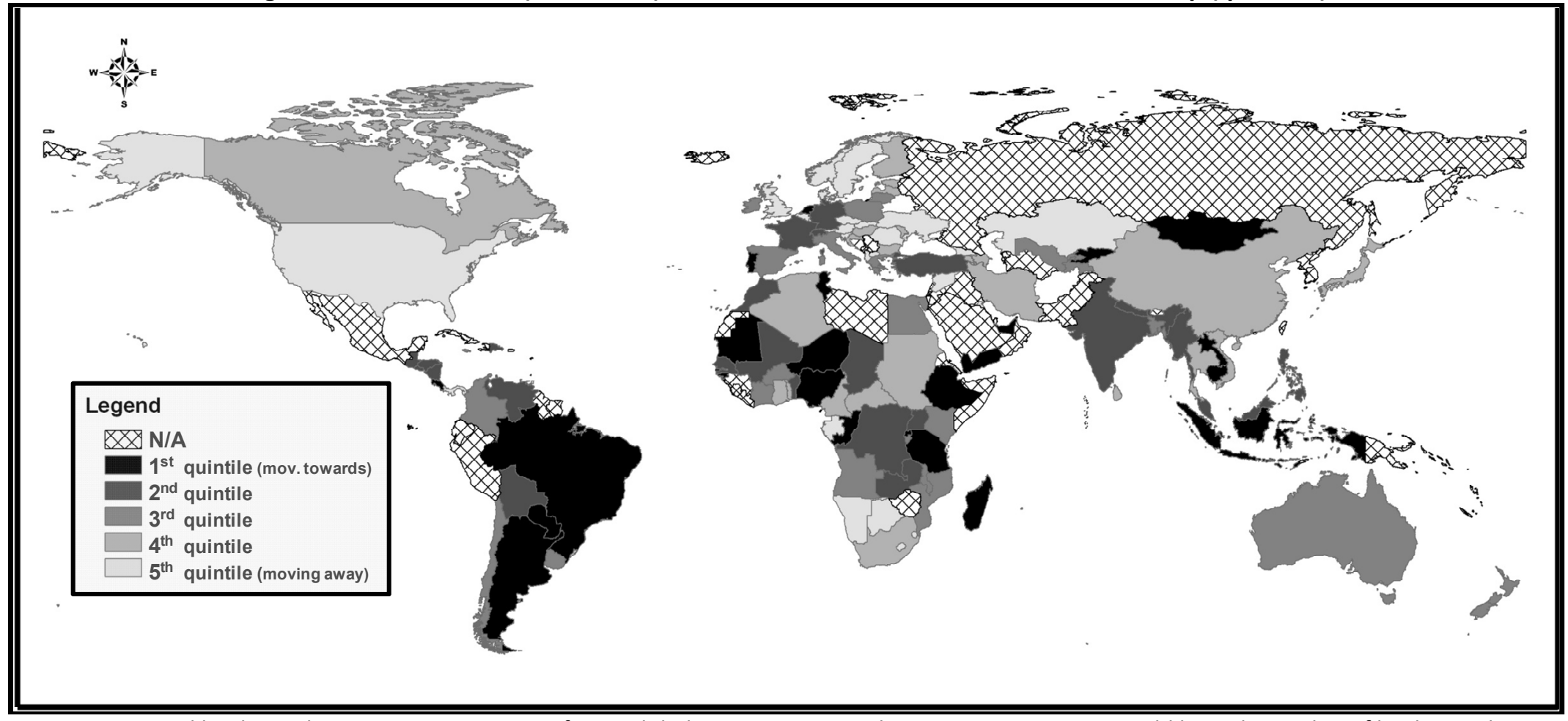

Source: Created by the author using ArcMap. Data from: Global Footprint Network, 2008; UNDP, 2008. World boundaries shapefile obtained from: DIVA-GIS, Thematic Mapping. World Countries Boundary File, World, 2002. Licensed under a Creative Commons Attribution 3.0 License. Downloaded from: http://finder.geocommons.com/overlays/5603 


\subsection{Analysis using Rank Lists and the Pearson Moment Correlation Function}

A wide array of environmental, social, economic, and governance performance metrics selected using the subsystems and elements listed in Table 2-3 as a guide - are tested for correlation with the rank lists obtained for Distance From the Quadrant and historical Movement Towards the Quadrant. This is done with the purpose of identifying the metrics that could be significantly associated with sustainable (or unsustainable) development, according to the Quadrant approach.

\subsubsection{Creating Country Rank Lists for the Metrics to be Tested}

For each individual metric selected, countries are ranked from the largest to the smallest value. For the historical movement analysis, the difference in value between the period's starting year and end year is calculated, and the countries are ranked according to overall progress. All gross measures were transformed to per capita values, or to percent of total land area where applicable, in order to make objective comparisons between nations (and so, to be able to rank the countries and create the lists for the analysis).

The purpose of using rank lists, instead of raw values, to test correlation, is to avoid errors caused by outliers. Nevertheless, it should be noted that using rank lists can somewhat alter the true distance that exists between different values.

The rank lists are created automatically by an Excel function; thus, for some metrics where a small value is 'good' (e.g., child mortality), the countries that figure in the top ranks are actually the ones that are worse off. This is why it is very important to examine the Interpretation column provided in the result tables (Chapter 5 ) before assuming that a correlation between a given metric and movement/distance relative to the Quadrant is positive or negative.

\subsubsection{Finding Correlations Using Pearson's R}

The relationship between each selected metric and movement/distance relative to the Quadrant is determined by calculating the Pearson product-moment correlation coefficient (R) between the two respective country rank lists. Pearson's $R$ indicates "the degree to which a linear predictive relationship exists between two variables. If both variables increase together across countries, a positive correlation results in a value from 0 to +1.0 . Conversely, an inverse relationship between the metrics would yield a negative correlation coefficient, between 0 and $-1.0 "$ (Wilson, et al., 2007).

The Pearson product-moment correlation coefficient is obtained using the following formula (3):

$$
r=\frac{1}{n-1} \sum_{i=1}^{n}\left(\frac{X_{i}-\bar{X}}{s_{X}}\right)\left(\frac{Y_{i}-\bar{Y}}{s_{Y}}\right)
$$


Where:

$$
\begin{array}{ll}
X_{i} & \text { is the score (in our case, a given country's rank) } \\
\bar{X} & \text { is the sample mean } \\
S_{x} & \text { is the sample's standard deviation } \\
n & \text { is the number of countries in the sample }
\end{array}
$$

It should be noted that, for each specific metric, the analysis is performed considering only the countries where data are available for both the metric and distance/movement relative to the Quadrant. In other words, for each metric tested, the correlation considers only the countries present in both rank lists compared; these countries makes up the sample.

Figure 4-17 illustrates how the Pearson product-moment correlation is conducted using the rank lists for an individual metric and movement/distance relative to the Quadrant. This particular Figure describes how the correlation method is used to analyze the relationship between longterm (1980 to 2005) Movement Towards the Quadrant and the metric: meat consumption per capita. The correlation coefficient obtained $(-0.4)$ indicates that countries that have increased their meat consumption per capita between 1980 and 2005, have tended to move away from the Quadrant. 
Figure 4-17: Sample Analysis Using Pearson Moment Correlation and Rank Lists

\begin{tabular}{|c|c|c|c|c|c|}
\hline & $\begin{array}{c}\text { Eco } \\
\text { Footprint } \\
\text { Index }\end{array}$ & $\mathrm{HDI}$ & $\begin{array}{l}\text { movemen } \\
(1980-200\end{array}$ & & Rank \\
\hline Norway & 0.328 & 0.067 & 0.395 & & 1 \\
\hline Argentina & 0.231 & 0.064 & 0.295 & & 2 \\
\hline Nepal & 0.017 & 0.213 & 0.230 & & 3 \\
\hline Uruguay & 0.150 & 0.080 & 0.230 & & 4 \\
\hline Germany & 0.148 & 0.072 & 0.220 & & 5 \\
\hline Hungary & 0.145 & 0.072 & 0.217 & & 6 \\
\hline United Arab Emirates & 0.057 & 0.158 & 0.215 & & 7 \\
\hline Indonesia & 0.010 & 0.199 & 0.209 & & 8 \\
\hline Trinidad and Tobago & 0.177 & 0.027 & 0.204 & & 9 \\
\hline Egypt & $(0.026)$ & 0.229 & 0.203 & & 10 \\
\hline \multicolumn{6}{|c|}{ Meat Consumption per capita - Kg. per person } \\
\hline & 1980 & 2005 & change & Rank & \\
\hline Denmark & 84.9 & 145.9 & 61 & 1 & \\
\hline Spain & 71.5 & 118.6 & 47.1 & 2 & \\
\hline Israel & 51.6 & 97.1 & 45.5 & 3 & \\
\hline Portugal & 46.3 & 91.1 & 44.8 & 4 & \\
\hline Brazil & 41.7 & 82.4 & 40.7 & 5 & \\
\hline China & 14.6 & 52.4 & 37.8 & 6 & \\
\hline Chile & 32 & 66.4 & 34.4 & 7 & \\
\hline Ireland & 74.7 & 106.3 & 31.6 & 8 & \\
\hline Malaysia & 23.2 & 50.9 & 27.7 & 9 & \\
\hline Ecuador & 20.8 & 45 & 24.2 & 10 & \\
\hline
\end{tabular}

Note: The rank lists shown in the figure are incomplete. The complete lists contain the same set of countries.

Source: Created by the author. Data from: Global Footprint Network, 2008; UNDP, 2008; FAO, 2004.

\subsubsection{Determining Statistical Significance for Pearson's R}

"[T]he interpretation of a correlation coefficient depends on the context and purposes. A correlation of 0.9 may be very low if one is verifying a physical law using high-quality instruments, but may be regarded as very high in the social sciences where there may be a greater contribution from complicating factors..." (Cohen, 1988). 
A full interpretation of any given metric's relationship with a concept as complex as global sustainability is a task beyond the scope of this work. Nevertheless, to determine the correlations' statistical significance is indeed a feasible task, and one that could serve as a stepping stone for more complete interpretations in the future.

Statistical significance for the Pearson moment correlation coefficient $(R)$ is determined using a table of Critical Values for Pearson's R. Once the number of samples ( $n$ ) and the correlation coefficient $(R)$ are known, the desired alpha level, $P\left(H_{0}\right)$, has to be set. The alpha level indicates the "likelihood of being incorrect when we say the relationship we found in our sample reflects a relationship in the population." (Del Siegle, 2009). Explained in different terms, the alpha level determines the probability with which the null hypothesis $\left(H_{0}\right)$ can be rejected. The null hypothesis suggests that the correlation coefficient (R) obtained for a number of samples $(n)$ is actually a random occurrence (i.e., there is no actual correlation). If, for a given number of samples, $R$ is greater than the corresponding critical value found in the table using an alpha level of 0.001 , the null hypothesis can be rejected with $99.9 \%$ confidence.

The table of critical values for Pearson's R can be found in Appendix F. 


\subsection{Description of Data Sources}

The Ecological Footprint (EF) and the Human Development Index (HDI) are the cornerstones of the analysis methodology proposed for this work. Present-day and historical data for both of these were obtained, respectively, from:

- Global Footprint Network. National Footprint Accounts. 2008 edition. (www.footprintnetwork.org.)

- United Nations Development Programme (UNDP). 2008. Human Development Reports, 2008 (http://hdr.undp.org).

Aside from these measuring frameworks, a vast amount of metrics were selected to be tested for correlation with distance/movement relative to the Quadrant. This selection was made to include metrics that represent all of the subsystems and elements listed in Table 2-3 (Section 2.3.). Multiple metrics were found for most of the elements.

As indicated in Section 3.2.3., the number of countries that have both EF and HDI data for the latest available year (2005) is 142 . The metrics were sourced for all the countries available within these 142.

\subsubsection{Present-day Distance From the Quadrant - Metrics Tested}

A total of 738 metrics were tested for correlation with present-day Distance From the Quadrant. Figures for the year 2005 were used in the analysis ${ }^{22}$ whenever available; if not, the most recent available year was taken. The main data sources that were employed in the present-day analysis are:

- The Compendium of Environmental Sustainability Indicator Collections compiled by Columbia University's Socioeconomic Data and Applications Center (SEDAC). "The compendium includes several collections of national-level sustainability indicators," as well as 'raw' data/variables and aggregated indices." (SEDAC, 2007). This compendium includes a total of 411 metrics, which themselves were taken from the sources listed in Table 4-7.

\footnotetext{
${ }^{22}$ As of this publication, 2005 is the most recent year when complete country measures for both HDI and
} EF are available, so it has been taken to represent the 'present-day' in this work. 
Table 4-7: Sources used in the SEDAC Compendium of Environmental Sustainability Indicator Collections

Source: Adapted from SEDAC, 2007.

\begin{tabular}{|l|c|l|}
\hline \multicolumn{1}{|c|}{ Indicator Collection } & $\begin{array}{c}\text { Number } \\
\text { of } \\
\text { Metrics }\end{array}$ & \multicolumn{1}{|c|}{ Original Source } \\
\hline $\begin{array}{l}2006 \text { Environmental } \\
\text { Performance Index }\end{array}$ & 39 & $\begin{array}{l}\text { Esty, D.C., M.A. Levy, T. Srebotnjak, A. de Sherbinin, } \\
\text { C.H. Kim, and B. Anderson (2006). Pilot 2006 } \\
\text { Environmental Performance Index. New Haven: Yale } \\
\text { Center for Environmental Law \& Policy. }\end{array}$ \\
\hline $\begin{array}{l}2005 \text { Environmental } \\
\text { Sustainability Index }\end{array}$ & 103 & $\begin{array}{l}\text { Esty, D.C., M. Levy, T. Srebotnjak, and Alexander de } \\
\text { Sherbinin (2005). 2005 Environmental Sustainability } \\
\text { Index: Benchmarking National Environmental } \\
\text { Stewardship. New Haven: Yale Center for } \\
\text { Environmental Law \& Policy. }\end{array}$ \\
\hline $\begin{array}{l}2004 \text { Environmental } \\
\text { Vulnerability Index }\end{array}$ & 111 & $\begin{array}{l}\text { Kaly, U.L., Pratt, C.R. and Mitchell, J. 2004. The } \\
\text { Demonstration Environmental Vulnerability Index } \\
\text { (EVI) 2004. SOPAC Technical Report 384. }\end{array}$ \\
\hline $\begin{array}{l}\text { Rio to Johannesburg } \\
\text { Dashboard of Sustainability }\end{array}$ & 35 & $\begin{array}{l}\text { O'Connor, J., and J. Jesinghaus. 2001. Rio to } \\
\text { Johannesburg Dashboard of Sustainability, } \\
\text { http://esl.jrc.it/envind/dashbrds.htm }\end{array}$ \\
\hline The Wellbeing of Nations & 123 & $\begin{array}{l}\text { Prescott-Allen, R. 2001. The Wellbeing of Nations: A } \\
\text { Country-by-Country Index of Quality of Life and the } \\
\text { Environment. Washington, DC: Island Press. }\end{array}$ \\
\hline
\end{tabular}

Among the indicators/metrics included in the compendium there are measures for: biodiversity, habitat and species conditions, wilderness protection, forest cover, forest resource use and management, land use, desertification, climate conditions, marine conditions, geographic conditions, energy sources, energy use, water resources, water use and access, air quality, soil quality, emissions to air, water, and soil, crops, livestock, agricultural inputs and outputs, subsidies, fishing, industry, mining, population, education, fertility, human health, mortality, disease, nutrition, sanitation, institutional capacity, environmental stewardship, governance, corruption, civil and political liberties, conflicts, violence, crime, poverty, gender issues, inequality, housing, development aid, international cooperation, eco-efficiency, recycling and waste, science and technology, transportation, urbanization, information technology, communications, natural hazards, markets, trade, investments, income, wealth, debt, and tourism.

To view the complete list of indicators/metrics obtained from this source, visit the SEDAC Compendium's website and download their Data Dictionary at: http://sedac.ciesin.columbia.edu/es/compendium.html

- $\quad$ The World Resources Institute's Earth Trends Web Portal (http://earthtrends.wri.org/). "Earth Trends is a comprehensive online database, maintained by the World Resources Institute, that focuses on the environmental, social, and economic trends that shape our world." (World 
Resources Institute, 2009). Table 4-8 lists the 220 metrics used in this analysis that were sourced from Earth Trends' vast wealth of data.

Table 4-8: List of Present-Day Metrics Sourced from the Earth Trends Web Portal Source: Compiled by the author.

\begin{tabular}{|c|c|c|}
\hline$\#$ & Metric & Year \\
\hline 1 & Total population, both sexes & 2005 \\
\hline 2 & Land: Total area & 2005 \\
\hline 3 & Civil liberties index & 2005 \\
\hline 4 & Control of Corruption Index & 2005 \\
\hline 5 & Level of freedom index & 2005 \\
\hline 6 & Political rights index & 2005 \\
\hline 7 & Political Stability and Absence of Violence Index & 2005 \\
\hline 8 & Press freedom index & 2005 \\
\hline 9 & Regulatory Quality Index & 2005 \\
\hline 10 & Religious freedom index & 2000 \\
\hline 11 & Rule of Law Index & 2005 \\
\hline 12 & Foreign direct investment, net inflows & 2005 \\
\hline 13 & Transnational Corporations: Number of foreign affiliates & 1993-2005 \\
\hline 14 & Transnational Corporations: Number of parent enterprises & 1993-2005 \\
\hline 15 & Investment in telecommunications & 2005 \\
\hline 16 & $\begin{array}{l}\text { Density of international non-governmental organizations with } \\
\text { membership }\end{array}$ & 2003 \\
\hline 17 & Corruption: Bribe Payer's Index & 2006 \\
\hline 18 & Corruption perceptions index & 2005 \\
\hline 19 & Present value of debt as a percent of GNI & 2005 \\
\hline 20 & Total debt service & 2005 \\
\hline 21 & Total debt service as a percent of export earnings & 2005 \\
\hline 22 & Total external debt & 2005 \\
\hline 23 & (External )Aid as a percent of government expenditure & 2005 \\
\hline 24 & Aid (received) per capita & 2005 \\
\hline 25 & Government cash deficit/surplus as a percent of GDP & 2005 \\
\hline 26 & Government consumption expenditure as a percent of GDP & 2005 \\
\hline 27 & Military expenditure as a percent of GDP & 2005 \\
\hline 28 & Military expenditure as a percent of government expenditure & 2005 \\
\hline 29 & Public education expenditure as a percent of GDP & 2005 \\
\hline 30 & Public health expenditure as a percent of GDP & 2005 \\
\hline 31 & Cost to register property & 2005 \\
\hline 32 & Cost to start a new business & 2005 \\
\hline 33 & Time required to register property & 2005 \\
\hline
\end{tabular}


Table 4-8 (continued)

\begin{tabular}{|c|c|c|}
\hline \# & Metric & Year \\
\hline 34 & Time required to start a new business & 2005 \\
\hline 35 & Water Poverty Index & 2002 \\
\hline 36 & Organic water pollutant (BOD) emissions & 2002 \\
\hline 37 & Internal Renewable Water Resources (IRWR): Dependency ratio & $1960-2007$ \\
\hline 38 & Access to an improved water source & 2004 \\
\hline 39 & Access to improved sanitation & 2004 \\
\hline 40 & Rural access to an improved water source & 2004 \\
\hline 41 & Rural access to improved sanitation & 2004 \\
\hline 42 & Urban access to an improved water source & 2004 \\
\hline 43 & Urban access to improved sanitation & 2004 \\
\hline 44 & Carbon monoxide emissions & 2000 \\
\hline 45 & Nitrogen oxides emissions & 2000 \\
\hline 46 & Non-methane VOC emissions & 2000 \\
\hline 47 & Sulfur dioxide emissions & 2000 \\
\hline 48 & Cumulative emissions from land use change & $1950-2000$ \\
\hline 49 & CO2 emissions per capita & 2004 \\
\hline 50 & Residential CO2 emissions per capita & 2003 \\
\hline 51 & CO2 emissions per GDP & 2004 \\
\hline 52 & Non-CO2 Greenhouse Gas Emissions: Fluorinated gases & 2000 \\
\hline 53 & Non-CO2 Greenhouse Gas Emissions: Methane & 2000 \\
\hline 54 & Non-CO2 Greenhouse Gas Emissions: Nitrous oxide & 2000 \\
\hline 55 & Cellular mobile telephone subscribers per 1000 people & 2005 \\
\hline 56 & Homes with personal computers & 2004 \\
\hline 57 & Homes with telephones & 2004 \\
\hline 58 & Internet users per 1000 people & 2005 \\
\hline 59 & Television sets per 1000 people & 2005 \\
\hline 60 & AIDS/HIV: Antiretroviral therapy coverage & 2005 \\
\hline 61 & AIDS/HIV: Adults and children living with HIV & 2005 \\
\hline 62 & Average annual reduction in under-5 mortality & $1990-2005$ \\
\hline 63 & Infant mortality rate & 2005 \\
\hline 64 & Stunting in children under 5--moderate and severe & $1996-2005$ \\
\hline 65 & Under-5 mortality rate & 2005 \\
\hline 66 & Underweight children under 5--moderate and severe & 1996-2005 \\
\hline 67 & Wasting in children under 5--moderate and severe & 1996-2005 \\
\hline 68 & Crude birth rate & $2005-2010$ \\
\hline 69 & Crude death rate & $2005-2010$ \\
\hline
\end{tabular}


Table 4-8 (continued)

\begin{tabular}{|c|c|c|}
\hline \# & Metric & Year \\
\hline 70 & Life expectancy at birth, both sexes & $2005-2010$ \\
\hline 71 & Net number of migrants & $2005-2010$ \\
\hline 72 & Total fertility rate & $2005-2010$ \\
\hline 73 & Internally displaced persons & 2006 \\
\hline 74 & Average length of schooling, both sexes & 2004 \\
\hline 75 & Primary school net enrollment ratio & 2004 \\
\hline 76 & Secondary school gender parity in gross enrollment & 2004 \\
\hline 77 & Secondary school net enrollment ratio & 2004 \\
\hline 78 & Tertiary school gross enrollment ratio, female & 2004 \\
\hline 79 & Lack of Durability of Housing & 2001 \\
\hline 80 & \% Owner Occupied Housing Units, Rural & $1984-1999$ \\
\hline 81 & \% Owner Occupied Housing Units, Urban & 1984-1999 \\
\hline 82 & Lack of Sufficient Living Area & 2001 \\
\hline 83 & Percent of urban population living in slums & 2001 \\
\hline 84 & Women Headed Households, Percent of Total & 1990-1999 \\
\hline 85 & Agricultural labor force as a percent of total labor force & 2004 \\
\hline 86 & Female professional and technical workers, percent of total & $1994-2005$ \\
\hline 87 & Female literacy rate as a percentage of male literacy rate & $2000-2004$ \\
\hline 88 & Literacy rate, all adults & $2000-2004$ \\
\hline 89 & Literacy rate, youth (age 15 to 24 ) & $2000-2004$ \\
\hline 90 & Population above age 65 , both sexes & 2005 \\
\hline 91 & Population below age 15 , both sexes & 2005 \\
\hline 92 & Growth rate of total population & $2005-2010$ \\
\hline 93 & Population density & 2005 \\
\hline 94 & Alcohol consumption per capita & 2003 \\
\hline 95 & Contraceptive prevalence rate & 1986-2004 \\
\hline 96 & Women with unmet need for family planning & $1986-2004$ \\
\hline 97 & $\begin{array}{l}\text { Government expenditure on health as a percent of total expenditure } \\
\text { on health }\end{array}$ & 2003 \\
\hline 98 & Per capita total expenditure on health & 2003 \\
\hline 99 & Solid fuel use & 2004 \\
\hline 100 & Passenger cars per 1000 people & 2003 \\
\hline 101 & Deaths due to road accidents & 2000 \\
\hline 102 & Pump prices for diesel fuel & 2002 \\
\hline 103 & Pump prices for super gasoline & 2002 \\
\hline 104 & Road traffic, million vehicle-kilometers & 2000 \\
\hline 105 & Total road network & 2000 \\
\hline
\end{tabular}


Table 4-8 (continued)

\begin{tabular}{|c|c|c|}
\hline 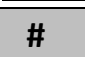 & Metric & Year \\
\hline 106 & Total vehicles per $\mathrm{km}$ road & 2000 \\
\hline 107 & Volume of public road transport & 2000 \\
\hline 108 & Growth rate of rural population & $2005-2010$ \\
\hline 109 & Growth rate of urban population & $2005-2010$ \\
\hline 110 & Total population in cities with more than 100,000 inhabitants & 2002 \\
\hline 111 & Total population in cities with more than one million inhabitants & 2002 \\
\hline 112 & Urban population as a percent of total population & 2005 \\
\hline 113 & Share of total household expenditure, education & 2005 \\
\hline 114 & Base of the Pyramid: Share of total household expenditure, energy & 2005 \\
\hline 115 & Base of the Pyramid: Share of total household expenditure, food & 2005 \\
\hline 116 & Base of the Pyramid: Share of total household expenditure, health & 2005 \\
\hline 117 & $\begin{array}{l}\text { Base of the Pyramid: Share of total household expenditure, household } \\
\text { goods }\end{array}$ & 2005 \\
\hline 118 & Base of the Pyramid: Share of total household expenditure, housing & 2005 \\
\hline 119 & $\begin{array}{l}\text { Base of the Pyramid: Share of total household expenditure, } \\
\text { information and communication technology }\end{array}$ & 2005 \\
\hline 120 & $\begin{array}{l}\text { Base of the Pyramid: Share of total household expenditure, } \\
\text { transportation }\end{array}$ & 2005 \\
\hline 121 & Base of the Pyramid: Share of total household expenditure, water & 2005 \\
\hline 122 & Aid as a percent of GNI & 2005 \\
\hline 123 & $\begin{array}{l}\text { Financial Flows: Net Inflows (sales - purchases) of Cross-Border } \\
\text { Mergers and Acquisitions }\end{array}$ & 2004 \\
\hline 124 & GDP per capita, annual growth rate & 2005 \\
\hline 125 & GDP per capita, PPP, current international dollars & 2005 \\
\hline 126 & GDP: Official exchange rate & 2005 \\
\hline 127 & Percent GDP from agriculture & 2005 \\
\hline 128 & Percent GDP from industry & 2005 \\
\hline 129 & Percent GDP from manufacturing & 2005 \\
\hline 130 & Percent GDP from services & 2005 \\
\hline 131 & GNI: PPP, current international dollars & 2005 \\
\hline 132 & Income Equality: Gini Index & $1992-2005$ \\
\hline 133 & Share of total income, highest $20 \%$ of population & $1992-2005$ \\
\hline 134 & Share of total income, fourth $20 \%$ of population & $1992-2005$ \\
\hline 135 & Share of total income, lowest $20 \%$ of population & $1992-2005$ \\
\hline 136 & Share of total income, second $20 \%$ of population & $1992-2005$ \\
\hline 137 & Share of total income, third $20 \%$ of population & $1992-2005$ \\
\hline 138 & Workers' remittances and compensation of employees, paid & 2005 \\
\hline
\end{tabular}


Table 4-8 (continued)

\begin{tabular}{|c|c|c|}
\hline \# & Metric & Year \\
\hline 139 & Workers' remittances and compensation of employees, received & 2005 \\
\hline 140 & $\begin{array}{l}\text { Micro, Small, and Medium Enterprises: MSME employment, percent of } \\
\text { total }\end{array}$ & 1994-2005 \\
\hline 141 & Micro, Small, and Medium Enterprises: MSMEs per 1000 people & 1994-2005 \\
\hline 142 & Adjusted Net Savings, percent of GNI & 2005 \\
\hline 143 & National poverty rates & $1987-2006$ \\
\hline 144 & National poverty rates, rural population & $1991-2006$ \\
\hline 145 & National poverty rates, urban population & $1991-2006$ \\
\hline 146 & International tourism expenditures & 2005 \\
\hline 147 & International tourism receipts & 2005 \\
\hline 148 & Trade in Forest Products: Imports, value & 2005 \\
\hline 149 & Trade in Goods and Services: Current account balance & 2005 \\
\hline 150 & Trade in Fish and Fisheries Products: Exports, quantity & 2005 \\
\hline 151 & Trade in Fish and Fisheries Products: Imports, quantity & 2005 \\
\hline 152 & $\begin{array}{l}\text { Trade in Goods and Services: Net trade in goods and services (balance } \\
\text { of trade) }\end{array}$ & 2005 \\
\hline 153 & $\begin{array}{l}\text { Trade in Goods: Agricultural raw materials exports as a percent of } \\
\text { merchandise exports }\end{array}$ & 2005 \\
\hline 154 & $\begin{array}{l}\text { Trade in Goods: Agricultural raw materials imports as a percent of } \\
\text { merchandise imports }\end{array}$ & 2005 \\
\hline 155 & Trade in Goods: Food exports as a percent of merchandise exports & 2005 \\
\hline 156 & Trade in Goods: Food imports as a percent of merchandise imports & 2005 \\
\hline 157 & Trade in Goods: Fuel exports as a percent of merchandise exports & 2005 \\
\hline 158 & Trade in Goods: Fuel imports as a percent of merchandise imports & 2005 \\
\hline 159 & $\begin{array}{l}\text { Trade in Goods: Manufactures exports as a percent of merchandise } \\
\text { exports }\end{array}$ & 2005 \\
\hline 160 & $\begin{array}{l}\text { Trade in Goods: Manufactures imports as a percent of merchandise } \\
\text { imports }\end{array}$ & 2005 \\
\hline 161 & Electricity consumption per capita & 2005 \\
\hline 162 & Total electricity production & 2005 \\
\hline 163 & Energy Consumption by Source: Biogas and liquid biomass & 2003 \\
\hline 164 & Energy Consumption by Source: Coal and coal products & 2005 \\
\hline 165 & Energy Consumption by Source: Hydroelectric & 2005 \\
\hline 166 & Energy Consumption by Source: Natural gas & 2005 \\
\hline 167 & Energy Consumption by Source: Oil and petroleum products & 2005 \\
\hline 168 & Energy Consumption by Source: Solar, wind, and wave & 2003 \\
\hline 169 & Energy Consumption by Source: Solid biomass (includes fuelwood) & 2003 \\
\hline
\end{tabular}


Table 4-8 (continued)

\begin{tabular}{|c|c|c|}
\hline \# & Metric & Year \\
\hline 170 & Residential energy consumption per capita & 2005 \\
\hline 171 & Total energy consumption per capita & 2005 \\
\hline 172 & Total energy production & 2005 \\
\hline 173 & Paper and paperboard consumption per capita & 2005 \\
\hline 174 & Diesel oil consumption per capita & 2003 \\
\hline 175 & Motor gasoline consumption per capita & 2003 \\
\hline 176 & Protected Areas: IUCN categories I-V, percent of total land area & 2006 \\
\hline 177 & $\begin{array}{l}\text { Protected Areas: IUCN categories I-VI and Other, percent of total land } \\
\text { area }\end{array}$ & 2006 \\
\hline 178 & Protected Areas: Larger than 100,000 hectares, number & 2006 \\
\hline 179 & Protected Areas: Marine and Littoral, number & 2006 \\
\hline 180 & Fertilizer use intensity & 2005 \\
\hline 181 & Pesticide use intensity & 2000 \\
\hline 182 & Agricultural Inputs: Tractor use intensity & 2003 \\
\hline 183 & Agricultural Inputs: Water use intensity & 2000 \\
\hline 184 & Food production per capita index & 2005 \\
\hline 185 & Agricultural Production Indices: Total production per capita index & 2005 \\
\hline 186 & Agricultural Production: Cereals, yield & 2005 \\
\hline 187 & Agricultural Production: Cereals, total production & 2005 \\
\hline 188 & Agricultural Production: Roots and tubers, yield & 2005 \\
\hline 189 & Food Aid: Cereals donated by country & 2005 \\
\hline 190 & Food Aid: Cereals received by country & 2005 \\
\hline 191 & Irrigated land as a percent of total agricultural area & 2003 \\
\hline 192 & Cattle stocks & 2005 \\
\hline 193 & Chicken stocks & 2005 \\
\hline 194 & Equine (horses, mules, asses) stocks & 2005 \\
\hline 195 & Goat stocks & 2005 \\
\hline 196 & Sheep stocks & 2005 \\
\hline 197 & Swine stocks & 2005 \\
\hline 198 & Turkey stocks & 2005 \\
\hline 199 & Meat Consumption: Per capita & 2002 \\
\hline 200 & Meat production per capita & 2005 \\
\hline 201 & Percentage of population that is undernourished & 2002-2004 \\
\hline 202 & Calorie supply per capita & 2003 \\
\hline 203 & Calorie supply per capita from animal products & 2002 \\
\hline 204 & Grain fed to livestock as a percent of total grain consumed & 2005 \\
\hline
\end{tabular}


Table 4-8 (continued)

\begin{tabular}{|c|l|c|}
\hline$\#$ & \multicolumn{1}{|c|}{ Metric } & Year \\
\hline 205 & Number of organic farms & $2005-2006$ \\
\hline 206 & Organic land area as a percent of total agricultural area & $2005-2006$ \\
\hline 207 & Food exports as a percent of merchandise exports & 2005 \\
\hline 208 & Dryland area as a percent of total area, average & 1999 \\
\hline 209 & Ecosystem Area: Barren or sparsely vegetated area & $1992-1993$ \\
\hline 210 & Urban and built-up areas & 2000 \\
\hline 211 & Paper Production: Recovered paper & 2005 \\
\hline 212 & Paper Production: Paper and paperboard & 2005 \\
\hline 213 & Forest area (current) as a percent of original forest area & 1996 \\
\hline 214 & Forest area (original) as a percent of total land area & 1996 \\
\hline 215 & Forest plantations area, average annual percent change & $2000-2005$ \\
\hline 216 & Frontier forest area as a percent of original forest area & 1996 \\
\hline 217 & Mangrove forest area & 1997 \\
\hline 218 & Forest Extent: Natural forest area & 2005 \\
\hline 219 & Total forest area & 2005 \\
\hline 220 & Paper and paperboard consumption per capita & 2005 \\
\hline
\end{tabular}

The original sources for these metrics are listed in Appendix B. Visit http://earthtrends.wri.org/ for more information about these metrics, including complete definitions, technical notes, methodologies, and other relevant information.

- A large number of metrics were taken from the database compiled by the United Nations Development Programme (UNDP) for their Human Development Reports, 2008. Table 4-9 lists the 62 metrics used in the present-day analysis that were sourced from this database.

Table 4-9: List of Metrics Sourced from the UNDP's Human Development Reports Source: Compiled by the author.

\begin{tabular}{|r|l|c|}
\hline \multicolumn{1}{|c|}{$\#$} & \multicolumn{1}{|c|}{ Metric } & Year \\
\hline 1 & Adult literacy rate (\% aged 15 and older) & $1995-2005$ \\
\hline 2 & Armed forces, index (1985=100) & 2007 \\
\hline 3 & Biomass and waste used for power (\% of total primary energy supply) & 2005 \\
\hline 4 & Births attended by skilled health personnel (\%) & $1997-2005$ \\
\hline 5 & Carbon intensity of energy (kt CO2 per kt of oil equivalent) & 2004 \\
\hline 6 & Carbon intensity of growth ( kt CO2 per million 2000 PPP US\$) & 2004 \\
\hline 7 & Carbon stocks in forests (living biomass) (Mt C) & 2005 \\
\hline 8 & Cellular subscribers (per 1,000 people) & 2005 \\
\hline 9 & CO2 emissions, average annual change (\%) & $1994-2004$ \\
\hline 10 & CO2 emissions/sequestration from forests (Mt CO2 per year) & $1990-2005$ \\
\hline
\end{tabular}


Table 4-9 (continued)

\begin{tabular}{|c|c|c|}
\hline \# & Metric & Year \\
\hline 11 & Coal (\% of total primary energy supply) & 2005 \\
\hline 12 & $\begin{array}{l}\text { Current public expenditure on education, pre-primary and primary (as } \\
\% \text { of all levels) }\end{array}$ & $2002-2005$ \\
\hline 13 & Current public expenditure on education, secondary (\% of all levels) & $2002-2005$ \\
\hline 14 & Current public expenditure on education, tertiary (\% of all levels) & $2002-2005$ \\
\hline 15 & $\begin{array}{l}\text { Debt service, total (\% of exports of goods, services and net income } \\
\text { from abroad) }\end{array}$ & 2005 \\
\hline 16 & Debt service, total (\% of GDP) & 2005 \\
\hline 17 & Electricity consumption per capita (\% change) & 2004 \\
\hline 18 & Employment in agriculture (\% of total employment) & 2005 \\
\hline 19 & Employment in industry (\% of total employment) & 2005 \\
\hline 20 & Employment in non-agricultural informal sector, both sexes (\%) & $1990-2004$ \\
\hline 21 & Employment in services (\% of total employment) & 2005 \\
\hline 22 & Employment, total (thousands) & 2005 \\
\hline 23 & Exports of goods and services (\% of GDP) & 2005 \\
\hline 24 & Fertility rate, total (births per woman) & 2005 \\
\hline 25 & Foreign direct investment, net inflows (\% of GDP) & 2005 \\
\hline 26 & Forest area (\% total land) 2005 Forest area, average annual change (\%) & $1990-2005$ \\
\hline 27 & Gas (\% of total primary energy supply) & 2005 \\
\hline 28 & GDP per capita (PPP US\$) & 2005 \\
\hline 29 & GDP per unit of energy use (\% change) & $1990-2004$ \\
\hline 30 & GDP per unit of energy use (2000 PPP US\$ per kg of oil equivalent) & 2004 \\
\hline 31 & Gender empowerment measure (GEM) value & 2005 \\
\hline 32 & Gender-related development index (GDI) rank & 2005 \\
\hline 33 & Gender-related development index (GDI) value & 2005 \\
\hline 34 & Health expenditure per capita (PPP US\$) & 2006 \\
\hline 35 & $\begin{array}{l}\text { Hydro, solar, wind and geothermal power (\% of total primary energy } \\
\text { supply) }\end{array}$ & 2005 \\
\hline 36 & Imports of goods and services (\% of GDP) & 2005 \\
\hline 37 & Long-term unemployment (\% of labor force) & 2006 \\
\hline 38 & Manufactured exports (\% of merchandise exports) & 2005 \\
\hline 39 & Maternal mortality ratio, adjusted (per 100,000 live births) & 2000 \\
\hline 40 & $\begin{array}{l}\text { Official development assistance per capita of donor country ( } 2005 \\
\text { US\$) }\end{array}$ & 2005 \\
\hline 41 & $\begin{array}{l}\text { Official development assistance received (net disbursements) (\% of } \\
\text { GDP) }\end{array}$ & 2005 \\
\hline 42 & $\begin{array}{l}\text { Official development assistance received (net disbursements) per } \\
\text { capita (US\$) }\end{array}$ & 2005 \\
\hline
\end{tabular}


Table 4-9 (continued)

\begin{tabular}{|r|l|c|}
\hline \multicolumn{1}{|c|}{ Metric } & \multicolumn{1}{|c|}{ Year } \\
\hline 43 & Oil (\% of total primary energy supply) & 2005 \\
\hline 44 & Patents granted to residents (per million people) & 2005 \\
\hline 45 & Physicians (per 100,000 people) & 2004 \\
\hline 46 & Population aged 65 and older (\% of total population) & 2005 \\
\hline 47 & Population under age 15 (\% of total population) & 2005 \\
\hline 48 & Population undernourished (\% of total population) & 2004 \\
\hline 49 & Population using an improved water source (\%) & 2004 \\
\hline 50 & Population using improved sanitation (\%) & 2004 \\
\hline 51 & Population without electricity (millions) & 2005 \\
\hline 52 & Private expenditure on health (\% of GDP) & 2004 \\
\hline 53 & Public expenditure on education (\% of total government expenditure) & $2002-2005$ \\
\hline 54 & Refugees by country of asylum (thousands) & 2006 \\
\hline 55 & Refugees by country of origin (thousands) & 2006 \\
\hline 56 & Research and development expenditure (\% of GDP) & 2005 \\
\hline 57 & Researchers in R\&D (per million people) & 2005 \\
\hline 58 & Telephone mainlines (per 1,000 people) & 2005 \\
\hline 59 & Tertiary students in science, engineering, manufacturing, and & $1999-2005$ \\
\hline 60 & Tonstruction (\%) & 2005 \\
\hline 61 & Unemployment rate Total (\% of labor force) & 2006 \\
\hline 62 & Unemployment rate Total (\% of labor force) & 2005 \\
\hline
\end{tabular}

Complete information about these metrics, including original sources and measuring methods, can be viewed on the statistics section of the Human Development Report's website: http://hdr.undp.org/en/statistics/data/

- $\quad$ The individual components of the 2005 Ecological Footprint were also tested for correlation with present-day Distance From the Quadrant. They were taken from the Global Footprint Network, National Footprint Accounts, 2008 edition. Table 4-10 lists these 30 individual components. 
Table 4-10: List of Individual Components of the 2005 Ecological Footprint Source: Compiled by the author.

\begin{tabular}{|r|l|}
\hline \multicolumn{1}{|l|}{ \# } & \multicolumn{1}{|c|}{ Ecological Footprint or Biocapacity Component } \\
\hline 1 & Footprint of local production per capita \\
\hline 2 & Footprint of imports per capita \\
\hline 3 & Footprint of exports per capita \\
\hline 4 & Footprint of local production - \% of total ecological footprint \\
\hline 5 & Footprint of imports - \% of total ecological footprint \\
\hline 6 & Footprint of exports - \% of total ecological footprint \\
\hline 7 & Cropland footprint per capita \\
\hline 8 & Grazing footprint per capita \\
\hline 9 & Forest footprint per capita \\
\hline 10 & Fishing footprint per capita \\
\hline 11 & Carbon footprint per capita \\
\hline 12 & Built-up land footprint per capita \\
\hline 13 & Cropland footprint - \% of total ecological footprint \\
\hline 14 & Grazing footprint - \% of total ecological footprint \\
\hline 15 & Forest footprint - \% of total ecological footprint \\
\hline 16 & Fishing footprint - \% of total ecological footprint \\
\hline 17 & Carbon footprint - \% of total ecological footprint \\
\hline 18 & Built-up land footprint - \% of total ecological footprint \\
\hline 19 & Cropland biocapacity per capita \\
\hline 20 & Grazing biocapacity per capita \\
\hline 21 & Forest biocapacity per capita \\
\hline 22 & Fishing biocapacity per capita \\
\hline 23 & Carbon biocapacity per capita \\
\hline 24 & Built-up land biocapacity per capita \\
\hline 25 & Cropland biocapacity - \% of total biocapacity \\
\hline 26 & Grazing biocapacity - \% of total biocapacity \\
\hline 27 & Forest biocapacity - \% of total biocapacity \\
\hline 28 & Fishing biocapacity - \% of total biocapacity \\
\hline 30 & Carbon biocapacity - \% of total biocapacity \\
\hline
\end{tabular}

- Data from the National Water Footprints were employed in the analysis as well. These data were taken from Hoekstra, A.Y. and Chapagain, A.K. (2008) Globalization of water: Sharing the planet's freshwater resources, Blackwell Publishing, Oxford, UK. The Water Footprint and its components are measured in units of water volume per capita. Table 4-11 lists the 11 individual components of the Water Footprint tested for correlation with Distance from 
the Quadrant. For more information on the Water Footprint, visit: http://www.waterfootprint.org.

Table 4-11: List of Individual Components of the Water Footprint (vears 1997-2001) Source: Compiled by the author.

\begin{tabular}{|r|l|}
\hline \multicolumn{1}{|c|}{$\#$} & \multicolumn{1}{|c|}{ Water Footprint Components } \\
\hline 1 & Total water footprint per capita \\
\hline 2 & Total renewable water resources per capita \\
\hline 3 & Water Scarcity (renewable water resources minus water footprint) \\
\hline 4 & Water import dependency \\
\hline 5 & Water self-sufficiency \\
\hline 6 & $\%$ of total water footprint used for agricultural production \\
\hline 8 & $\begin{array}{l}\% \text { of total water footprint used for industrial production } \\
\text { local production minus exports) }\end{array}$ \\
\hline 9 & $\begin{array}{l}\% \text { of internal water footprint used for industrial production (water embodied in local } \\
\text { production minus exports) }\end{array}$ \\
\hline 10 & $\begin{array}{l}\% \text { of external water footprint used for agricultural production (water embodied in } \\
\text { imports) }\end{array}$ \\
\hline 11 & $\begin{array}{l}\text { \% of external water footprint used for industrial production (water embodied in } \\
\text { imports) }\end{array}$ \\
\hline
\end{tabular}

- National ethnic, religious, and linguistic fractionalization scores were tested for correlation with Distance From the Quadrant as well. Fractionalization is "a measure of diversity among individuals" (Bossert, et al., 2006). Countries are given a score between 0 and 1, with higher scores indicating greater diversity. The data were taken from Alesina, Alberto, et al, 2003. "Fractionalization," Journal of Economic Growth, Springer, vol. 8(2), pages 155-94, June. In turn, Alesina, et al's work used the following sources for their analysis: Encyclopedia Britanica, the CIA World Factbook, the Minority Rights Group International, local census data, and previously published work by Scarrit and Mozaffar.

- $\quad$ Countries' average latitude was also tested for correlation in the present-day analysis. This data were taken from Mobilgistix Ltd. Average Latitude \& Longitude of Countries, 2009, available at http://www.mobilgistix.com/Resources/GIS/Locations/average-latitude-longitudecountries.aspx.

\subsubsection{Historical Movement Towards the Quadrant - Metrics Tested}

A total of 140 metrics were tested for correlation with historical Movement Towards the Quadrant. The bulk of these were sourced from The World Resources Institute's Earth Trends Web Portal (http://earthtrends.wri.org/), they are listed in Table 4-12. Note that the number of metrics available decreases as the time period considered goes further back in time; for the short-term analysis, data was available for 127 metrics; as opposed to 119 for the medium-term, 
and 86 for the long-term. A list of the original sources for these metrics can be found in Appendix B.

Table 4-12: Complete List of Metrics Analyzed for Historical Movement Sourced from the Earth Trends Portal

Source: Compiled by the author.

\begin{tabular}{|c|c|c|c|c|}
\hline \multirow{2}{*}{ \# } & \multirow{2}{*}{ Metric } & \multicolumn{3}{|c|}{ Period } \\
\hline & & Long-term & $\begin{array}{l}\text { Medium- } \\
\text { term }\end{array}$ & Short-term \\
\hline 1 & Total population, both sexes & $\begin{array}{l}1980 \text { to } \\
2005\end{array}$ & $\begin{array}{l}1990 \text { to } \\
2005\end{array}$ & $\begin{array}{l}2000 \text { to } \\
2005\end{array}$ \\
\hline 2 & Civil liberties index & $\begin{array}{c}1980 \text { to } \\
2005\end{array}$ & $\begin{array}{l}1990 \text { to } \\
2005\end{array}$ & $\begin{array}{l}2000 \text { to } \\
2005\end{array}$ \\
\hline 3 & Control of Corruption Index & $\mathrm{N} / \mathrm{A}$ & $\mathrm{N} / \mathrm{A}$ & $\begin{array}{l}2000 \text { to } \\
2005\end{array}$ \\
\hline 4 & Level of freedom index & $\begin{array}{l}1980 \text { to } \\
2005\end{array}$ & $\begin{array}{l}1990 \text { to } \\
2005\end{array}$ & $\begin{array}{l}2000 \text { to } \\
2005\end{array}$ \\
\hline 5 & Political rights index & $\begin{array}{l}1980 \text { to } \\
2005\end{array}$ & $\begin{array}{l}1989-90 \text { to } \\
2005\end{array}$ & $\begin{array}{l}2000 \text { to } \\
2005\end{array}$ \\
\hline 6 & $\begin{array}{l}\text { Political Stability and Absence of } \\
\text { Violence Index }\end{array}$ & N/A & $\mathrm{N} / \mathrm{A}$ & $\begin{array}{l}2000 \text { to } \\
2005\end{array}$ \\
\hline 7 & Press freedom index & N/A & $\mathrm{N} / \mathrm{A}$ & $\begin{array}{l}2000 \text { to } \\
2005\end{array}$ \\
\hline 8 & Regulatory Quality Index & $\mathrm{N} / \mathrm{A}$ & $\mathrm{N} / \mathrm{A}$ & $\begin{array}{l}2000 \text { to } \\
2005\end{array}$ \\
\hline 9 & Rule of Law Index & N/A & $\mathrm{N} / \mathrm{A}$ & $\begin{array}{l}2000 \text { to } \\
2005\end{array}$ \\
\hline 10 & $\begin{array}{l}\text { Transnational Corporations: Foreign } \\
\text { direct investment, net inflows }\end{array}$ & $\begin{array}{l}1980 \text { to } \\
2005\end{array}$ & $\begin{array}{l}1990 \text { to } \\
2005\end{array}$ & $\begin{array}{l}2000 \text { to } \\
2005\end{array}$ \\
\hline 11 & Investment in telecommunications & $\begin{array}{l}1980 \text { to } \\
2005\end{array}$ & $\begin{array}{l}1990 \text { to } \\
2005\end{array}$ & $\begin{array}{l}2000 \text { to } \\
2005\end{array}$ \\
\hline 12 & $\begin{array}{l}\text { Density of international non- } \\
\text { governmental organizations with } \\
\text { membership }\end{array}$ & $\mathrm{N} / \mathrm{A}$ & $\begin{array}{c}1990 \text { to } \\
2003\end{array}$ & $\begin{array}{c}2000 \text { to } \\
2003\end{array}$ \\
\hline 13 & Corruption perceptions index & $\begin{array}{l}1980-85 \text { to } \\
2005\end{array}$ & $\begin{array}{l}1988-92 \text { to } \\
2005\end{array}$ & $\begin{array}{l}2000 \text { to } \\
2005\end{array}$ \\
\hline 14 & Total debt service & $\begin{array}{l}1980 \text { to } \\
2005\end{array}$ & $\begin{array}{l}1990 \text { to } \\
2005\end{array}$ & $\begin{array}{l}2000 \text { to } \\
2005\end{array}$ \\
\hline 15 & $\begin{array}{l}\text { Total debt service as a percent of export } \\
\text { earnings }\end{array}$ & $\begin{array}{l}1980 \text { to } \\
2005\end{array}$ & $\begin{array}{l}1990 \text { to } \\
2005\end{array}$ & $\begin{array}{l}2000 \text { to } \\
2005\end{array}$ \\
\hline 16 & Total external debt & $\begin{array}{c}1980 \text { to } \\
2005\end{array}$ & $\begin{array}{c}1990 \text { to } \\
2005\end{array}$ & $\begin{array}{l}2000 \text { to } \\
2005\end{array}$ \\
\hline 17 & $\begin{array}{l}\text { (External )Aid as a percent of } \\
\text { government expenditure }\end{array}$ & N/A & $\begin{array}{l}1990 \text { to } \\
2005\end{array}$ & $\begin{array}{l}2000 \text { to } \\
2005\end{array}$ \\
\hline
\end{tabular}


Table 4-12 (continued)

\begin{tabular}{|c|c|c|c|c|}
\hline \multirow[b]{2}{*}{ \# } & \multirow[b]{2}{*}{ Metric } & \multicolumn{3}{|c|}{ Period } \\
\hline & & Long-term & $\begin{array}{l}\text { Medium- } \\
\text { term }\end{array}$ & Short-term \\
\hline 18 & Aid (received) per capita & $\begin{array}{l}1980 \text { to } \\
2005\end{array}$ & $\begin{array}{l}1990 \text { to } \\
2005\end{array}$ & $\begin{array}{l}2000 \text { to } \\
2005\end{array}$ \\
\hline 19 & $\begin{array}{l}\text { Government cash deficit/surplus as a } \\
\text { percent of GDP }\end{array}$ & N/A & $\begin{array}{c}1990 \text { to } \\
2005\end{array}$ & $\begin{array}{c}2000 \text { to } \\
2005\end{array}$ \\
\hline 20 & $\begin{array}{l}\text { Government consumption expenditure } \\
\text { as a percent of GDP }\end{array}$ & $\begin{array}{l}1980 \text { to } \\
2005\end{array}$ & $\begin{array}{l}1990 \text { to } \\
2005\end{array}$ & $\begin{array}{l}2000 \text { to } \\
2005\end{array}$ \\
\hline 21 & Military expenditure as a percent of GDP & $\mathrm{N} / \mathrm{A}$ & $\begin{array}{l}1990 \text { to } \\
2005\end{array}$ & $\begin{array}{l}2000 \text { to } \\
2005\end{array}$ \\
\hline 22 & $\begin{array}{l}\text { Military expenditure as a percent of } \\
\text { government expenditure }\end{array}$ & $\mathrm{N} / \mathrm{A}$ & $\begin{array}{c}1990 \text { to } \\
2005\end{array}$ & $\begin{array}{l}2000 \text { to } \\
2005\end{array}$ \\
\hline 23 & $\begin{array}{l}\text { Public education expenditure as a } \\
\text { percent of GDP }\end{array}$ & $\mathrm{N} / \mathrm{A}$ & $\begin{array}{c}1991 \text { to } \\
2005\end{array}$ & $\begin{array}{l}2000 \text { to } \\
2005\end{array}$ \\
\hline 24 & $\begin{array}{l}\text { Public health expenditure as a percent } \\
\text { of GDP }\end{array}$ & $\mathrm{N} / \mathrm{A}$ & $\mathrm{N} / \mathrm{A}$ & $\begin{array}{l}2001 \text { to } \\
2005\end{array}$ \\
\hline 25 & Organic water pollutant (BOD) emissions & $\begin{array}{l}1980 \text { to } \\
2002\end{array}$ & $\begin{array}{l}1990 \text { to } \\
2002\end{array}$ & $\begin{array}{l}2000 \text { to } \\
2002\end{array}$ \\
\hline 26 & Access to an improved water source & $\mathrm{N} / \mathrm{A}$ & $\begin{array}{l}1990 \text { to } \\
2004\end{array}$ & N/A \\
\hline 27 & Access to improved sanitation & N/A & $\begin{array}{c}1990 \text { to } \\
2004\end{array}$ & N/A \\
\hline 28 & $\begin{array}{l}\text { Rural access to an improved water } \\
\text { source }\end{array}$ & $\mathrm{N} / \mathrm{A}$ & $\begin{array}{c}1990 \text { to } \\
2004\end{array}$ & N/A \\
\hline 29 & Rural access to improved sanitation & $\mathrm{N} / \mathrm{A}$ & $\begin{array}{c}1990 \text { to } \\
2004\end{array}$ & $\mathrm{~N} / \mathrm{A}$ \\
\hline 30 & $\begin{array}{l}\text { Urban access to an improved water } \\
\text { source }\end{array}$ & $\mathrm{N} / \mathrm{A}$ & $\begin{array}{l}1990 \text { to } \\
2004\end{array}$ & $\mathrm{~N} / \mathrm{A}$ \\
\hline 31 & Urban access to improved sanitation & $\mathrm{N} / \mathrm{A}$ & $\begin{array}{l}1990 \text { to } \\
2004\end{array}$ & $\mathrm{~N} / \mathrm{A}$ \\
\hline 32 & CO2 emissions per capita & $\begin{array}{l}1980 \text { to } \\
2004\end{array}$ & $\begin{array}{c}1990 \text { to } \\
2004\end{array}$ & $\begin{array}{l}2000 \text { to } \\
2004\end{array}$ \\
\hline 33 & Residential CO2 emissions per capita & $\mathrm{N} / \mathrm{A}$ & $\begin{array}{c}1990 \text { to } \\
2003\end{array}$ & $\mathrm{~N} / \mathrm{A}$ \\
\hline 34 & CO2 emissions per GDP & $\begin{array}{l}1980 \text { to } \\
2004\end{array}$ & $\begin{array}{c}1990 \text { to } \\
2004\end{array}$ & $\begin{array}{l}2000 \text { to } \\
2004\end{array}$ \\
\hline 35 & $\begin{array}{l}\text { Cellular mobile telephone subscribers } \\
\text { per } 1000 \text { people }\end{array}$ & $\begin{array}{l}1980 \text { to } \\
2005\end{array}$ & $\begin{array}{l}1990 \text { to } \\
2005\end{array}$ & $\begin{array}{l}2000 \text { to } \\
2005\end{array}$ \\
\hline 36 & Homes with personal computers & $\mathrm{N} / \mathrm{A}$ & $\begin{array}{l}1990 \text { to } \\
2004\end{array}$ & $\begin{array}{l}2000 \text { to } \\
2004\end{array}$ \\
\hline 37 & Homes with telephones & 1980 to & 1990 to & 2000 to \\
\hline
\end{tabular}


Table 4-12 (continued)

\begin{tabular}{|c|c|c|c|c|}
\hline \multirow[b]{2}{*}{$\#$} & \multirow[b]{2}{*}{ Metric } & \multicolumn{3}{|c|}{ Period } \\
\hline & & Long-term & $\begin{array}{l}\text { Medium- } \\
\text { term }\end{array}$ & Short-term \\
\hline & & 2004 & 2004 & 2004 \\
\hline 38 & Internet users per 1000 people & N/A & $\begin{array}{l}1990 \text { to } \\
2005\end{array}$ & $\begin{array}{l}2000 \text { to } \\
2005\end{array}$ \\
\hline 39 & Television sets per 1000 people & $\begin{array}{c}1980 \text { to } \\
2005\end{array}$ & $\begin{array}{l}1990 \text { to } \\
2005\end{array}$ & $\begin{array}{l}2000 \text { to } \\
2005\end{array}$ \\
\hline 40 & Infant mortality rate & $\begin{array}{l}1980 \text { to } \\
2005\end{array}$ & $\begin{array}{l}1990 \text { to } \\
2005\end{array}$ & $\begin{array}{l}2000 \text { to } \\
2005\end{array}$ \\
\hline 41 & Under-5 mortality rate & $\begin{array}{l}1980 \text { to } \\
2005\end{array}$ & $\begin{array}{l}1990 \text { to } \\
2005\end{array}$ & $\begin{array}{l}2000 \text { to } \\
2005\end{array}$ \\
\hline 42 & Crude birth rate & $\begin{array}{c}1980-85 \text { to } \\
2005-10\end{array}$ & $\begin{array}{l}1990-95 \text { to } \\
2005-10\end{array}$ & $\begin{array}{l}2000-05 \text { to } \\
2005-10\end{array}$ \\
\hline 43 & Crude death rate & $\begin{array}{c}1980-85 \text { to } \\
2005-10\end{array}$ & $\begin{array}{c}1990-95 \text { to } \\
2005-10\end{array}$ & $\begin{array}{c}2000-05 \text { to } \\
2005-10\end{array}$ \\
\hline 44 & Life expectancy at birth, both sexes & $\begin{array}{c}1980-85 \text { to } \\
2005-10\end{array}$ & $\begin{array}{c}1990-95 \text { to } \\
2005-10\end{array}$ & $\begin{array}{c}2000-05 \text { to } \\
2005-10\end{array}$ \\
\hline 45 & Net number of migrants & $\begin{array}{c}1980-85 \text { to } \\
2005-10\end{array}$ & $\begin{array}{l}1990-95 \text { to } \\
2005-10\end{array}$ & $\begin{array}{c}2000-05 \text { to } \\
2005-10\end{array}$ \\
\hline 46 & Total fertility rate & $\begin{array}{c}1980-85 \text { to } \\
2005-10\end{array}$ & $\begin{array}{l}1990-95 \text { to } \\
2005-10\end{array}$ & $\begin{array}{c}2000-05 \text { to } \\
2005-10\end{array}$ \\
\hline 47 & Average length of schooling, both sexes & N/A & N/A & $\begin{array}{l}2000 \text { to } \\
2004\end{array}$ \\
\hline 48 & Primary school net enrollment ratio & N/A & N/A & $\begin{array}{l}2000 \text { to } \\
2004\end{array}$ \\
\hline 49 & $\begin{array}{l}\text { Secondary school gender parity in gross } \\
\text { enrollment }\end{array}$ & N/A & N/A & $\begin{array}{c}2000 \text { to } \\
2004\end{array}$ \\
\hline 50 & Secondary school net enrollment ratio & N/A & N/A & $\begin{array}{l}2000 \text { to } \\
2004\end{array}$ \\
\hline 51 & $\begin{array}{l}\text { Tertiary school gross enrollment ratio, } \\
\text { female }\end{array}$ & N/A & N/A & $\begin{array}{l}2000 \text { to } \\
2004\end{array}$ \\
\hline 52 & $\begin{array}{l}\text { Agricultural labor force as a percent of } \\
\text { total labor force }\end{array}$ & $\begin{array}{l}1980 \text { to } \\
2004\end{array}$ & $\begin{array}{l}1990 \text { to } \\
2004\end{array}$ & $\begin{array}{l}2000 \text { to } \\
2004\end{array}$ \\
\hline 53 & Population above age 65 , both sexes & $\begin{array}{c}1980 \text { to } \\
2005\end{array}$ & $\begin{array}{c}1990 \text { to } \\
2005\end{array}$ & $\begin{array}{c}2000 \text { to } \\
2005\end{array}$ \\
\hline 54 & Population below age 15 , both sexes & $\begin{array}{c}1980 \text { to } \\
2005\end{array}$ & $\begin{array}{c}1990 \text { to } \\
2005\end{array}$ & $\begin{array}{c}2000 \text { to } \\
2005\end{array}$ \\
\hline 55 & Growth rate of total population & $\begin{array}{c}1980-85 \text { to } \\
2005-10\end{array}$ & $\begin{array}{c}1990-95 \text { to } \\
2005-10\end{array}$ & $\begin{array}{c}2000-05 \text { to } \\
2005-10\end{array}$ \\
\hline 56 & Population density & $\begin{array}{c}1980 \text { to } \\
2005\end{array}$ & $\begin{array}{c}1990 \text { to } \\
2005\end{array}$ & $\begin{array}{c}2000 \text { to } \\
2005\end{array}$ \\
\hline 57 & Alcohol consumption per capita & 1980 to & 1990 to & 2000 to \\
\hline
\end{tabular}


Table 4-12 (continued)

\begin{tabular}{|c|c|c|c|c|}
\hline \multirow[b]{2}{*}{ \# } & \multirow[b]{2}{*}{ Metric } & \multicolumn{3}{|c|}{ Period } \\
\hline & & Long-term & $\begin{array}{l}\text { Medium- } \\
\text { term }\end{array}$ & Short-term \\
\hline & & 2003 & 2003 & 2003 \\
\hline 58 & $\begin{array}{l}\text { Government expenditure on health as a } \\
\text { percent of total expenditure on health }\end{array}$ & N/A & N/A & $\begin{array}{l}2000 \text { to } \\
2003\end{array}$ \\
\hline 59 & Per capita total expenditure on health & N/A & N/A & $\begin{array}{l}2000 \text { to } \\
2003\end{array}$ \\
\hline 60 & Passenger cars per 1000 people & $\begin{array}{l}1980 \text { to } \\
2003\end{array}$ & $\begin{array}{l}1990 \text { to } \\
2003\end{array}$ & $\begin{array}{l}2000 \text { to } \\
2003\end{array}$ \\
\hline 61 & Growth rate of rural population & $\begin{array}{c}1980-85 \text { to } \\
2005-10\end{array}$ & $\begin{array}{c}1990-95 \text { to } \\
2005-10\end{array}$ & $\begin{array}{c}2000-05 \text { to } \\
2005-10\end{array}$ \\
\hline 62 & Growth rate of urban population & $\begin{array}{c}1980-85 \text { to } \\
2005-10\end{array}$ & $\begin{array}{c}1990-95 \text { to } \\
2005-10\end{array}$ & $\begin{array}{c}2000-05 \text { to } \\
2005-10\end{array}$ \\
\hline 63 & $\begin{array}{l}\text { Urban population as a percent of total } \\
\text { population }\end{array}$ & $\begin{array}{l}1980 \text { to } \\
2005\end{array}$ & $\begin{array}{l}1990 \text { to } \\
2005\end{array}$ & $\begin{array}{l}2000 \text { to } \\
2005\end{array}$ \\
\hline 64 & Aid as a percent of GNI & $\begin{array}{l}1980 \text { to } \\
2005\end{array}$ & $\begin{array}{l}1990 \text { to } \\
2005\end{array}$ & $\begin{array}{l}2000 \text { to } \\
2005\end{array}$ \\
\hline 65 & $\begin{array}{l}\text { Financial Flows: Net Inflows (sales - } \\
\text { purchases) of Cross-Border Mergers and } \\
\text { Acquisitions }\end{array}$ & N/A & $\begin{array}{l}1990 \text { to } \\
2004-05\end{array}$ & $\begin{array}{l}2000 \text { to } \\
2004-05\end{array}$ \\
\hline 66 & GDP per capita, annual growth rate & $\begin{array}{l}1980 \text { to } \\
2005\end{array}$ & $\begin{array}{l}1990 \text { to } \\
2005\end{array}$ & $\begin{array}{l}2000 \text { to } \\
2005\end{array}$ \\
\hline 67 & $\begin{array}{l}\text { GDP per capita, PPP, current } \\
\text { international dollars }\end{array}$ & $\begin{array}{l}1980 \text { to } \\
2005\end{array}$ & $\begin{array}{l}1990 \text { to } \\
2005\end{array}$ & $\begin{array}{l}2000 \text { to } \\
2005\end{array}$ \\
\hline 68 & GDP: Official exchange rate & $\begin{array}{l}1980 \text { to } \\
2005\end{array}$ & $\begin{array}{l}1990 \text { to } \\
2005\end{array}$ & $\begin{array}{l}2000 \text { to } \\
2005\end{array}$ \\
\hline 69 & Percent GDP from agriculture & $\begin{array}{l}1980 \text { to } \\
2005\end{array}$ & $\begin{array}{l}1990 \text { to } \\
2005\end{array}$ & $\begin{array}{l}2000 \text { to } \\
2005\end{array}$ \\
\hline 70 & Percent GDP from industry & $\begin{array}{l}1980 \text { to } \\
2005\end{array}$ & $\begin{array}{l}1990 \text { to } \\
2005\end{array}$ & $\begin{array}{l}2000 \text { to } \\
2005\end{array}$ \\
\hline 71 & Percent GDP from manufacturing & $\begin{array}{l}1980 \text { to } \\
2005\end{array}$ & $\begin{array}{l}1990 \text { to } \\
2005\end{array}$ & $\begin{array}{l}2000 \text { to } \\
2005\end{array}$ \\
\hline 72 & Percent GDP from services & $\begin{array}{c}1980 \text { to } \\
2005\end{array}$ & $\begin{array}{c}1990 \text { to } \\
2005\end{array}$ & $\begin{array}{l}2000 \text { to } \\
2005\end{array}$ \\
\hline 73 & GNI: PPP, current international dollars & $\begin{array}{l}1980 \text { to } \\
2005\end{array}$ & $\begin{array}{l}1990 \text { to } \\
2005\end{array}$ & $\begin{array}{l}2000 \text { to } \\
2005\end{array}$ \\
\hline 74 & $\begin{array}{l}\text { Workers' remittances and compensation } \\
\text { of employees, paid }\end{array}$ & $\begin{array}{l}1980 \text { to } \\
2005\end{array}$ & $\begin{array}{l}1990 \text { to } \\
2005\end{array}$ & $\begin{array}{l}2000 \text { to } \\
2005\end{array}$ \\
\hline 75 & $\begin{array}{l}\text { Workers' remittances and compensation } \\
\text { of employees, received }\end{array}$ & $\begin{array}{l}1980 \text { to } \\
2005\end{array}$ & $\begin{array}{c}1990 \text { to } \\
2005\end{array}$ & $\begin{array}{l}2000 \text { to } \\
2005\end{array}$ \\
\hline 76 & Adjusted Net Savings, percent of GNI & N/A & $\begin{array}{l}1990 \text { to } \\
2005\end{array}$ & $\begin{array}{l}2000 \text { to } \\
2005\end{array}$ \\
\hline
\end{tabular}


Table 4-12 (continued)

\begin{tabular}{|c|c|c|c|c|}
\hline \multirow[b]{2}{*}{ \# } & \multirow[b]{2}{*}{ Metric } & \multicolumn{3}{|c|}{ Period } \\
\hline & & Long-term & $\begin{array}{l}\text { Medium- } \\
\text { term }\end{array}$ & Short-term \\
\hline 77 & International tourism expenditures & N/A & N/A & $\begin{array}{l}2000 \text { to } \\
2005\end{array}$ \\
\hline 78 & International tourism receipts & N/A & N/A & $\begin{array}{c}2000 \text { to } \\
2005\end{array}$ \\
\hline 79 & Trade in Forest Products: Imports, value & $\begin{array}{c}1980 \text { to } \\
2005\end{array}$ & $\begin{array}{c}1990 \text { to } \\
2005\end{array}$ & $\begin{array}{c}2000 \text { to } \\
2005\end{array}$ \\
\hline 80 & $\begin{array}{l}\text { Trade in Goods and Services: Current } \\
\text { account balance }\end{array}$ & $\begin{array}{l}1980 \text { to } \\
2005\end{array}$ & $\begin{array}{c}1990 \text { to } \\
2005\end{array}$ & $\begin{array}{l}2000 \text { to } \\
2005\end{array}$ \\
\hline 81 & $\begin{array}{l}\text { Trade in Fish and Fisheries Products: } \\
\text { Exports, quantity }\end{array}$ & $\begin{array}{c}1980 \text { to } \\
2005\end{array}$ & $\begin{array}{c}1990 \text { to } \\
2005\end{array}$ & $\begin{array}{c}2000 \text { to } \\
2005\end{array}$ \\
\hline 82 & $\begin{array}{l}\text { Trade in Fish and Fisheries Products: } \\
\text { Imports, quantity }\end{array}$ & $\begin{array}{c}1980 \text { to } \\
2005\end{array}$ & $\begin{array}{c}1990 \text { to } \\
2005\end{array}$ & $\begin{array}{l}2000 \text { to } \\
2005\end{array}$ \\
\hline 83 & $\begin{array}{l}\text { Trade in Goods and Services: Net trade } \\
\text { in goods and services (balance of trade) }\end{array}$ & $\begin{array}{c}1980 \text { to } \\
2005\end{array}$ & $\begin{array}{c}1990 \text { to } \\
2005\end{array}$ & $\begin{array}{c}2000 \text { to } \\
2005\end{array}$ \\
\hline 84 & $\begin{array}{l}\text { Trade in Goods: Agricultural raw } \\
\text { materials exports as a percent of } \\
\text { merchandise exports }\end{array}$ & $\begin{array}{l}1980 \text { to } \\
2005\end{array}$ & $\begin{array}{l}1990 \text { to } \\
2005\end{array}$ & $\begin{array}{l}2000 \text { to } \\
2005\end{array}$ \\
\hline 85 & $\begin{array}{l}\text { Trade in Goods: Agricultural raw } \\
\text { materials imports as a percent of } \\
\text { merchandise imports }\end{array}$ & $\begin{array}{c}1980 \text { to } \\
2005\end{array}$ & $\begin{array}{c}1990 \text { to } \\
2005\end{array}$ & $\begin{array}{c}2000 \text { to } \\
2005\end{array}$ \\
\hline 86 & $\begin{array}{l}\text { Trade in Goods: Food exports as a } \\
\text { percent of merchandise exports }\end{array}$ & $\begin{array}{c}1980 \text { to } \\
2005\end{array}$ & $\begin{array}{c}1990 \text { to } \\
2005\end{array}$ & $\begin{array}{l}2000 \text { to } \\
2005\end{array}$ \\
\hline 87 & $\begin{array}{l}\text { Trade in Goods: Food imports as a } \\
\text { percent of merchandise imports }\end{array}$ & $\begin{array}{c}1980 \text { to } \\
2005\end{array}$ & $\begin{array}{c}1990 \text { to } \\
2005\end{array}$ & $\begin{array}{c}2000 \text { to } \\
2005\end{array}$ \\
\hline 88 & $\begin{array}{l}\text { Trade in Goods: Fuel exports as a } \\
\text { percent of merchandise exports }\end{array}$ & $\begin{array}{l}1980 \text { to } \\
2005\end{array}$ & $\begin{array}{c}1990 \text { to } \\
2005\end{array}$ & $\begin{array}{l}2000 \text { to } \\
2005\end{array}$ \\
\hline 89 & $\begin{array}{l}\text { Trade in Goods: Fuel imports as a } \\
\text { percent of merchandise imports }\end{array}$ & $\begin{array}{c}1980 \text { to } \\
2005\end{array}$ & $\begin{array}{c}1990 \text { to } \\
2005\end{array}$ & $\begin{array}{c}2000 \text { to } \\
2005\end{array}$ \\
\hline 90 & $\begin{array}{l}\text { Trade in Goods: Manufactures exports } \\
\text { as a percent of merchandise exports }\end{array}$ & $\begin{array}{l}1980 \text { to } \\
2005\end{array}$ & $\begin{array}{c}1990 \text { to } \\
2005\end{array}$ & $\begin{array}{l}2000 \text { to } \\
2005\end{array}$ \\
\hline 91 & $\begin{array}{l}\text { Trade in Goods: Manufactures imports } \\
\text { as a percent of merchandise imports }\end{array}$ & $\begin{array}{l}1980 \text { to } \\
2005\end{array}$ & $\begin{array}{l}1990 \text { to } \\
2005\end{array}$ & $\begin{array}{l}2000 \text { to } \\
2005\end{array}$ \\
\hline 92 & Electricity consumption per capita & N/A & $\begin{array}{c}1990 \text { to } \\
2005\end{array}$ & $\begin{array}{c}2000 \text { to } \\
2005\end{array}$ \\
\hline 93 & Total electricity production & N/A & $\begin{array}{c}1990 \text { to } \\
2005\end{array}$ & $\begin{array}{l}2000 \text { to } \\
2005\end{array}$ \\
\hline 94 & $\begin{array}{l}\text { Energy Consumption by Source: Biogas } \\
\text { and liquid biomass }\end{array}$ & N/A & $\begin{array}{c}1990 \text { to } \\
2003\end{array}$ & $\begin{array}{l}2000 \text { to } \\
2003\end{array}$ \\
\hline 95 & $\begin{array}{l}\text { Energy Consumption by Source: Coal } \\
\text { and coal products }\end{array}$ & N/A & $\begin{array}{l}1990 \text { to } \\
2005\end{array}$ & $\begin{array}{l}2000 \text { to } \\
2005\end{array}$ \\
\hline
\end{tabular}


Table 4-12 (continued)

\begin{tabular}{|c|c|c|c|c|}
\hline \multirow[b]{2}{*}{ \# } & \multirow[b]{2}{*}{ Metric } & \multicolumn{3}{|c|}{ Period } \\
\hline & & Long-term & $\begin{array}{l}\text { Medium- } \\
\text { term }\end{array}$ & Short-term \\
\hline 96 & $\begin{array}{l}\text { Energy Consumption by Source: } \\
\text { Hydroelectric }\end{array}$ & N/A & $\begin{array}{c}1990 \text { to } \\
2005\end{array}$ & $\begin{array}{l}2000 \text { to } \\
2005\end{array}$ \\
\hline 97 & $\begin{array}{l}\text { Energy Consumption by Source: Natural } \\
\text { gas }\end{array}$ & N/A & $\begin{array}{c}1990 \text { to } \\
2005\end{array}$ & $\begin{array}{l}2000 \text { to } \\
2005\end{array}$ \\
\hline 98 & $\begin{array}{l}\text { Energy Consumption by Source: Oil and } \\
\text { petroleum products }\end{array}$ & $\mathrm{N} / \mathrm{A}$ & $\begin{array}{c}1990 \text { to } \\
2005\end{array}$ & $\begin{array}{c}2000 \text { to } \\
2005\end{array}$ \\
\hline 99 & $\begin{array}{l}\text { Energy Consumption by Source: Solar, } \\
\text { wind, and wave }\end{array}$ & N/A & $\begin{array}{l}1990 \text { to } \\
2003\end{array}$ & $\begin{array}{l}2000 \text { to } \\
2003\end{array}$ \\
\hline 100 & $\begin{array}{l}\text { Energy Consumption by Source: Solid } \\
\text { biomass (includes fuelwood) }\end{array}$ & N/A & $\begin{array}{c}1990 \text { to } \\
2003\end{array}$ & $\begin{array}{l}2000 \text { to } \\
2003\end{array}$ \\
\hline 101 & $\begin{array}{l}\text { Residential energy consumption per } \\
\text { capita }\end{array}$ & N/A & $\begin{array}{l}1990 \text { to } \\
2005\end{array}$ & $\begin{array}{l}2000 \text { to } \\
2005\end{array}$ \\
\hline 102 & Total energy consumption per capita & N/A & $\begin{array}{c}1990 \text { to } \\
2005\end{array}$ & $\begin{array}{l}2000 \text { to } \\
2005\end{array}$ \\
\hline 103 & Total energy production & N/A & $\begin{array}{c}1990 \text { to } \\
2005\end{array}$ & $\begin{array}{c}2000 \text { to } \\
2005\end{array}$ \\
\hline 104 & $\begin{array}{l}\text { Paper and paperboard consumption per } \\
\text { capita }\end{array}$ & $\begin{array}{c}1980 \text { to } \\
2005\end{array}$ & $\begin{array}{l}1990 \text { to } \\
2005\end{array}$ & $\begin{array}{l}2000 \text { to } \\
2005\end{array}$ \\
\hline 105 & Diesel oil consumption per capita & N/A & $\begin{array}{l}1990 \text { to } \\
2003\end{array}$ & $\begin{array}{l}2000 \text { to } \\
2003\end{array}$ \\
\hline 106 & Motor gasoline consumption per capita & N/A & $\begin{array}{l}1990 \text { to } \\
2003\end{array}$ & $\begin{array}{l}2000 \text { to } \\
2003\end{array}$ \\
\hline 107 & Agricultural Inputs: Tractor use intensity & $\begin{array}{c}1980 \text { to } \\
2003\end{array}$ & $\begin{array}{c}1990 \text { to } \\
2003\end{array}$ & $\begin{array}{c}2000 \text { to } \\
2003\end{array}$ \\
\hline 108 & Food production per capita index & $\begin{array}{c}1980 \text { to } \\
2005\end{array}$ & $\begin{array}{c}1990 \text { to } \\
2005\end{array}$ & $\begin{array}{l}2000 \text { to } \\
2005\end{array}$ \\
\hline 109 & $\begin{array}{l}\text { Agricultural Production Indices: Total } \\
\text { production per capita index }\end{array}$ & $\begin{array}{l}1980 \text { to } \\
2005\end{array}$ & $\begin{array}{l}1990 \text { to } \\
2005\end{array}$ & $\begin{array}{l}2000 \text { to } \\
2005\end{array}$ \\
\hline 110 & Agricultural Production: Cereals, yield & $\begin{array}{c}1980 \text { to } \\
2005\end{array}$ & $\begin{array}{l}1990 \text { to } \\
2005\end{array}$ & $\begin{array}{l}2000 \text { to } \\
2005\end{array}$ \\
\hline 111 & $\begin{array}{l}\text { Agricultural Production: Cereals, total } \\
\text { production }\end{array}$ & $\begin{array}{l}1980 \text { to } \\
2005\end{array}$ & $\begin{array}{l}1990 \text { to } \\
2005\end{array}$ & $\begin{array}{l}2000 \text { to } \\
2005\end{array}$ \\
\hline 112 & $\begin{array}{l}\text { Agricultural Production: Roots and } \\
\text { tubers, total production }\end{array}$ & $\begin{array}{l}1980 \text { to } \\
2005\end{array}$ & $\begin{array}{l}1990 \text { to } \\
2005\end{array}$ & $\begin{array}{l}2000 \text { to } \\
2005\end{array}$ \\
\hline 113 & $\begin{array}{l}\text { Agricultural Production: Roots and } \\
\text { tubers, yield }\end{array}$ & $\begin{array}{c}1980 \text { to } \\
2005\end{array}$ & $\begin{array}{l}1990 \text { to } \\
2005\end{array}$ & $\begin{array}{l}2000 \text { to } \\
2005\end{array}$ \\
\hline 114 & Food Aid: Cereals received by country & $\begin{array}{l}1980 \text { to } \\
2005\end{array}$ & $\begin{array}{l}1990 \text { to } \\
2005\end{array}$ & $\begin{array}{l}2000 \text { to } \\
2005\end{array}$ \\
\hline 115 & $\begin{array}{l}\text { Irrigated land as a percent of total } \\
\text { agricultural area }\end{array}$ & $\begin{array}{l}1980 \text { to } \\
2003\end{array}$ & $\begin{array}{c}1990 \text { to } \\
2003\end{array}$ & $\begin{array}{l}2000 \text { to } \\
2003\end{array}$ \\
\hline
\end{tabular}


Table 4-12 (continued)

\begin{tabular}{|c|c|c|c|c|}
\hline \multirow[b]{2}{*}{ \# } & \multirow[b]{2}{*}{ Metric } & \multicolumn{3}{|c|}{ Period } \\
\hline & & Long-term & $\begin{array}{l}\text { Medium- } \\
\text { term }\end{array}$ & Short-term \\
\hline 116 & Cattle stocks & $\begin{array}{l}1980 \text { to } \\
2005\end{array}$ & $\begin{array}{l}1990 \text { to } \\
2005\end{array}$ & $\begin{array}{l}2000 \text { to } \\
2005\end{array}$ \\
\hline 117 & Chicken stocks & $\begin{array}{c}1980 \text { to } \\
2005\end{array}$ & $\begin{array}{l}1990 \text { to } \\
2005\end{array}$ & $\begin{array}{l}2000 \text { to } \\
2005\end{array}$ \\
\hline 118 & Equine (horses, mules, asses) stocks & $\begin{array}{c}1980 \text { to } \\
2005\end{array}$ & $\begin{array}{l}1990 \text { to } \\
2005\end{array}$ & $\begin{array}{l}2000 \text { to } \\
2005\end{array}$ \\
\hline 119 & Goat stocks & $\begin{array}{l}1980 \text { to } \\
2005\end{array}$ & $\begin{array}{l}1990 \text { to } \\
2005\end{array}$ & $\begin{array}{l}2000 \text { to } \\
2005\end{array}$ \\
\hline 120 & Sheep stocks & $\begin{array}{c}1980 \text { to } \\
2005\end{array}$ & $\begin{array}{c}1990 \text { to } \\
2005\end{array}$ & $\begin{array}{l}2000 \text { to } \\
2005\end{array}$ \\
\hline 121 & Swine stocks & $\begin{array}{l}1980 \text { to } \\
2005\end{array}$ & $\begin{array}{l}1990 \text { to } \\
2005\end{array}$ & $\begin{array}{l}2000 \text { to } \\
2005\end{array}$ \\
\hline 122 & Meat Consumption: Per capita & $\begin{array}{c}1980 \text { to } \\
2002\end{array}$ & $\begin{array}{c}1990 \text { to } \\
2002\end{array}$ & $\begin{array}{c}2000 \text { to } \\
2002\end{array}$ \\
\hline 123 & Meat production per capita & $\begin{array}{l}1980 \text { to } \\
2005\end{array}$ & $\begin{array}{l}1990 \text { to } \\
2005\end{array}$ & $\begin{array}{l}2000 \text { to } \\
2005\end{array}$ \\
\hline 124 & $\begin{array}{l}\text { Percentage of population that is } \\
\text { undernourished }\end{array}$ & $\begin{array}{c}1979-81 \text { to } \\
2002-04\end{array}$ & $\begin{array}{c}1990-92 \text { to } \\
2002-04\end{array}$ & $\begin{array}{c}2001-03 \text { to } \\
2002-04\end{array}$ \\
\hline 125 & Calorie supply per capita & $\begin{array}{l}1980 \text { to } \\
2003\end{array}$ & $\begin{array}{l}1990 \text { to } \\
2003\end{array}$ & $\begin{array}{l}2000 \text { to } \\
2003\end{array}$ \\
\hline 126 & $\begin{array}{l}\text { Calorie supply per capita from animal } \\
\text { products }\end{array}$ & $\begin{array}{c}1980 \text { to } \\
2002\end{array}$ & $\begin{array}{c}1990 \text { to } \\
2002\end{array}$ & $\begin{array}{c}2000 \text { to } \\
2002\end{array}$ \\
\hline 127 & $\begin{array}{l}\text { Grain fed to livestock as a percent of } \\
\text { total grain consumed }\end{array}$ & $\begin{array}{l}1980 \text { to } \\
2005\end{array}$ & $\begin{array}{c}1990 \text { to } \\
2005\end{array}$ & $\begin{array}{l}2000 \text { to } \\
2005\end{array}$ \\
\hline 128 & $\begin{array}{l}\text { Food exports as a percent of } \\
\text { merchandise exports }\end{array}$ & $\begin{array}{c}1980 \text { to } \\
2005\end{array}$ & $\begin{array}{c}1990 \text { to } \\
2005\end{array}$ & $\begin{array}{l}2000 \text { to } \\
2005\end{array}$ \\
\hline 129 & $\begin{array}{l}\text { Food imports as a percent of } \\
\text { merchandise imports }\end{array}$ & $\begin{array}{l}1980 \text { to } \\
2005\end{array}$ & $\begin{array}{l}1990 \text { to } \\
2005\end{array}$ & $\begin{array}{l}2000 \text { to } \\
2005\end{array}$ \\
\hline 130 & Paper Production: Recovered paper & $\begin{array}{l}1980 \text { to } \\
2005\end{array}$ & $\begin{array}{l}1990 \text { to } \\
2005\end{array}$ & $\begin{array}{l}2000 \text { to } \\
2005\end{array}$ \\
\hline 131 & $\begin{array}{l}\text { Paper Production: Paper and } \\
\text { paperboard }\end{array}$ & $\begin{array}{l}1980 \text { to } \\
2005\end{array}$ & $\begin{array}{l}1990 \text { to } \\
2005\end{array}$ & $\begin{array}{l}2000 \text { to } \\
2005\end{array}$ \\
\hline 132 & Forest Extent: Natural forest area & N/A & $\begin{array}{l}1990 \text { to } \\
2005\end{array}$ & $\begin{array}{l}2000 \text { to } \\
2005\end{array}$ \\
\hline 133 & Total forest area & N/A & $\begin{array}{l}1990 \text { to } \\
2005\end{array}$ & $\begin{array}{l}2000 \text { to } \\
2005\end{array}$ \\
\hline 134 & $\begin{array}{l}\text { Paper and paperboard consumption per } \\
\text { capita }\end{array}$ & $\begin{array}{l}1980 \text { to } \\
2005\end{array}$ & $\begin{array}{l}1990 \text { to } \\
2005\end{array}$ & $\begin{array}{l}2000 \text { to } \\
2005\end{array}$ \\
\hline
\end{tabular}


The other set of data used from the historical movement analysis comes from the Ecological Footprint time series (Global Footprint Network, National Footprint Accounts, 2008 edition). The EF time series has complete data from all the Ecological Footprint and Biocapacity components from 1961 to 2005, which allows for an analysis of the change in time for each of the component's share in the total footprint. The EF components selected for the historical movement analysis (on all - long, medium, and short - terms considered) are listed in Table 413.

Table 4-13: List of Ecological Footprint Components Analyzed for Historical Movement Source: Compiled by the author.

\begin{tabular}{|l|l|}
\hline$\#$ & Metric \\
\hline 1 & Ecological Footprint of Cropland - \% of total \\
\hline 2 & Ecological Footprint of Grazing land - \% of total \\
\hline 3 & Ecological Footprint of Forest land - \% of total \\
\hline 4 & Ecological Footprint of Fishing ground - \% of total \\
\hline 5 & Ecological Footprint of Carbon - \% of total \\
\hline 6 & Ecological Footprint of Built-up land - \% of total \\
\hline
\end{tabular}




\section{Results of the Analysis}

The present-day Distance From the Quadrant analysis yielded a much larger number of metrics with statistically significant correlations than the historical Movement Towards the Quadrant analysis; this is not unexpected, since data availability was much greater for the present-day. A total of 738 metrics were tested for the present-day analysis, as opposed to 127 metrics for the short-term movement analysis (2000 to 2005); 119 for the medium-term analysis (1990 to 2005), and 86 for the long-term analysis (1980 to 2005).

As was indicated in Section 3.3., the purpose of the analysis was to identify metrics that correlate with some degree of statistical significance with proximity/movement relative to the Global Sustainability Quadrant.

\subsection{Metric Correlations with Highest Statistical Significance}

This section lists only those metrics identified in the analysis that show correlation with the highest possible statistical significance. Statistical significance was determined using the table of critical values for Pearson's $R$ described in Section 4.4.3. (Table 4-7). A rejection of the null hypothesis ${ }^{23}$ with $99.9 \%$ confidence $\left(P\left(H_{0}\right)=<0.001\right)$ is the highest possible confidence allowed by the table.

Appendix $\mathrm{C}$ lists all the metrics that showed some degree of statistical significance - rejection of the null hypothesis with at least $90 \%$ confidence $\left(P\left(H_{0}\right)=0.1\right)$. See Appendix $D$ for a list of complete definitions and original sources for these statistically significant metrics.

\subsubsection{Present-Day Correlations with the Highest Statistical Significance}

Before arriving at any conclusion about sustainability based on the present-day ${ }^{24}$ results, a fact that should not be overlooked is that, even though the approach provides a good snapshot of where in relation to the Sustainability Quadrant countries are positioned today, it reveals nothing about the direction they are moving in - which ultimately should be more relevant to researchers and policy-makers alike.

Table 5-1 lists those metrics that showed the highest statistical significance, $\mathrm{P}\left(\mathrm{H}_{0}\right)=<0.001$, in the present-day Distance From the Quadrant analysis. The total number of present-day metrics that meet this criterion is 58 , but only those with a Pearson correlation coefficient $(R)$ value above absolute 0.5 are included in Table 5-1 (for the complete list, see Appendix C). They are ranked according to their $\mathrm{R}$ value, from strongest to weakest correlation. The Interpretation

\footnotetext{
${ }^{23}$ The null hypothesis, $H_{0}$, indicates that there is no correlation between the variables analyzed. The probability for the null hypothesis, $P\left(H_{0}\right)$, is the probability that a correlation coefficient obtained for a number of samples $n$ is actually a random occurrence.

${ }^{24}$ As of this publication, 2005 is the most recent year when complete country measures for both HDI and EF are available, so it has been taken to represent the 'present-day' in this work.
} 
column explains the meaning of the correlation, and occasionally offers a merely speculative explanation for it. Arriving at more concrete and reliable explanations for the correlations is out of the scope of this work, but it does constitute an interesting opportunity for further research. 
Table 5-1: Present-Day Correlations with the Highest Statistical Significance, $P\left(H_{0}\right)=\langle 0.001$, and $R>|0.5|$

$\mathrm{n}=$ number of pairs of data (countries).

$\mathrm{R}=$ Pearson moment correlation coefficient.

Source: Created by the author. See Section 4.5 for data sources.

\begin{tabular}{|c|c|c|c|c|}
\hline Rank & Metric & $\mathbf{n}$ & $\mathbf{R}$ & Interpretation \\
\hline 1 & $\begin{array}{l}\text { Corruption: Bribe Payer's Index } \\
\text { (score from } 0 \text { to 10, with } 10 \\
\text { being the "best" or less corrupt) }\end{array}$ & 29 & $(0.724)$ & $\begin{array}{l}\text { "The Bribe Payer's Index (BPI) measures the tendency of firms from } \\
\text { top exporting countries to pay bribes or make undocumented } \\
\text { payments while conducting business abroad." Quoted from the } \\
\text { Earth Trends portal. } \\
\text { The negative correlation indicates that more "corrupt" countries } \\
\text { tend to be closer to the Quadrant. Note that this metric includes } \\
\text { only } 29 \text { top exporting countries. Thus, no assumptions should be } \\
\text { made about corruption and its relationship with sustainability, but } \\
\text { most certainly it is not cause-effect. }\end{array}$ \\
\hline 2 & $\begin{array}{l}\text { Contraceptive Prevalence Rate } \\
\text { (\% of married women aged } 15- \\
49 \text { practicing contraception) }\end{array}$ & 87 & 0.686 & $\begin{array}{l}\text { Countries where contraception is more widespread tend to be closer } \\
\text { to the Quadrant. }\end{array}$ \\
\hline 3 & $\begin{array}{l}\text { Development Assistance: Aid } \\
\text { received as a percent of } \mathrm{GNI}\end{array}$ & 103 & $(0.660)$ & $\begin{array}{l}\text { Countries that receive more official development assistance (ODA) } \\
\text { relative to their GNI tend to be farther away from the Quadrant. } \\
\text { Perhaps this is a sign that ODA is being assigned where it is needed } \\
\text { the most, or that it is usually very ineffective in fostering sustainable } \\
\text { development. }\end{array}$ \\
\hline 4 & $\begin{array}{l}\text { Population without electricity (\% } \\
\text { of the population) }\end{array}$ & 77 & $(0.657)$ & $\begin{array}{l}\text { Countries where larger parts of the population do not have } \\
\text { electricity tend to be farther away from the Quadrant. }\end{array}$ \\
\hline 5 & $\begin{array}{l}\text { Official development asst. } \\
\text { received (net disbursements) (\% } \\
\text { of GDP) }\end{array}$ & 96 & $(0.654)$ & $\begin{array}{l}\text { Countries that receive more official development assistance (ODA) } \\
\text { relative to their GDP tend to be farther away from the Quadrant. } \\
\text { Perhaps this is a sign that ODA is being assigned where it is needed } \\
\text { the most, or that it is usually very ineffective in fostering sustainable } \\
\text { development. }\end{array}$ \\
\hline
\end{tabular}


Table 5-1 (continued)

\begin{tabular}{|c|c|c|c|c|}
\hline Rank & Metric & n & $\mathbf{R}$ & Interpretation \\
\hline 6 & $\begin{array}{l}\text { Debt: Total debt service (current } \\
\text { US\$ per person) }\end{array}$ & 109 & 0.641 & $\begin{array}{l}\text { Countries with higher debts tend to be closer to the Quadrant. } \\
\text { Perhaps this explains how they got there (by borrowing money)... }\end{array}$ \\
\hline 7 & $\begin{array}{l}\text { Children's Health: Stunting in } \\
\text { children under 5--moderate and } \\
\text { severe }(\%)\end{array}$ & 107 & $(0.579)$ & $\begin{array}{l}\text { "Stunting in children under } 5 \text {-- moderate and severe, an indicator of } \\
\text { child malnutrition, refers to the proportion of children under } 5 \\
\text { whose height-for-age is below minus } 2 \text { standard deviations (for } \\
\text { moderate stunting) or below minus } 3 \text { standard deviations (for severe } \\
\text { stunting) from the median height-for-age of an international } \\
\text { reference population recognized by the World Health Organization } \\
\text { (WHO)." Quoted from the Earth Trends portal. } \\
\text { Countries where stunting is more widespread tend to be farther } \\
\text { away from the Quadrant. }\end{array}$ \\
\hline 8 & $\begin{array}{l}\text { Death rate from intestinal } \\
\text { infectious diseases (deaths per } \\
100,000 \text { population) }\end{array}$ & 70 & 0.574 & $\begin{array}{l}\text { It should be noted that this sample of } 70 \text { does not include any } \\
\text { African nation, so among those that are included, the ones with } \\
\text { higher death rates from intestinal infectious diseases tend to be } \\
\text { closer to the Quadrant. }\end{array}$ \\
\hline 9 & $\begin{array}{l}\text { Total external debt (current US\$ } \\
\text { per person) }\end{array}$ & 109 & 0.570 & $\begin{array}{l}\text { Countries with higher debts tend to be closer to the Quadrant. } \\
\text { Perhaps this explains how they got there (by borrowing money)... }\end{array}$ \\
\hline 10 & $\begin{array}{l}\text { Children's Health: Underweight } \\
\text { children under 5--moderate and } \\
\text { severe (\%) }\end{array}$ & 108 & $(0.569)$ & $\begin{array}{l}\text { Countries where the percentage of children considered underweight } \\
\text { (which is an indicator of malnutrition) is higher tend to be farther } \\
\text { away from the Quadrant. }\end{array}$ \\
\hline 11 & $\begin{array}{l}\text { Percentage of the population } \\
\text { with insufficient food }\end{array}$ & 89 & $(0.567)$ & $\begin{array}{l}\text { Countries where the percentage of the population with insufficient } \\
\text { food is higher tend to be farther away from the Quadrant. }\end{array}$ \\
\hline 12 & $\begin{array}{l}\text { Literacy: Female literacy rate as } \\
\text { a percentage of male literacy } \\
\text { rate }(\%)\end{array}$ & 97 & 0.552 & $\begin{array}{l}\text { Countries where the percentage of literate females, in relation to the } \\
\text { percentage of literate males, is higher tend to be closer to the } \\
\text { Quadrant. }\end{array}$ \\
\hline
\end{tabular}


Table 5-1 (continued)

\begin{tabular}{|c|c|c|c|c|}
\hline Rank & Metric & $\mathbf{n}$ & $\mathbf{R}$ & Interpretation \\
\hline 13 & $\begin{array}{l}\text { Literacy: Literacy rate, all adults } \\
\text { (\%) }\end{array}$ & 97 & 0.550 & $\begin{array}{l}\text { Countries where the percentage of literate adults is higher tend to } \\
\text { be closer to the Quadrant. }\end{array}$ \\
\hline 14 & $\begin{array}{l}\text { Literacy: Literacy rate, youth } \\
\text { (age } 15 \text { to } 24 \text { ) (\%) }\end{array}$ & 93 & 0.549 & $\begin{array}{l}\text { Countries where the percentage of literate youths is higher tend to } \\
\text { be closer to the Quadrant. }\end{array}$ \\
\hline 15 & $\begin{array}{l}\text { Adult literacy rate (\% aged } 15 \text { or } \\
\text { older) }\end{array}$ & 113 & 0.549 & $\begin{array}{l}\text { Countries where the percentage of literate people over } 15 \text { is higher } \\
\text { tend to be closer to the Quadrant. }\end{array}$ \\
\hline 16 & $\begin{array}{l}\text { Transportation: Passenger cars } \\
\text { per } 1000 \text { people }\end{array}$ & 48 & $(0.547)$ & $\begin{array}{l}\text { "These numbers exclude buses, freight vehicles, and two-wheelers } \\
\text { such as mopeds and motorcycles." Quoted from the Earth Trends } \\
\text { portal. Nevertheless, they do include taxis, so the metric is not } \\
\text { restricted to private vehicles. } \\
\text { Countries where passenger cars are more widespread tend to be } \\
\text { farther away from the Quadrant. }\end{array}$ \\
\hline 17 & $\begin{array}{l}\text { Children's Health: Wasting in } \\
\text { children under } 5 \text {--moderate and } \\
\text { severe }(\%)\end{array}$ & 105 & (0.529) & $\begin{array}{l}\text { Wasting in children under 5--moderate and severe, an indicator of } \\
\text { child malnutrition, refers to the proportion of children under } 5 \\
\text { whose weight-for-height is below minus } 2 \text { standard deviations (for } \\
\text { moderate wasting) or below minus } 3 \text { standard deviations (for severe } \\
\text { wasting) from the median weight-for-height of an international } \\
\text { reference population recognized by the World Health Organization } \\
\text { (WHO). Quoted from the Earth Trends portal. } \\
\text { Countries where wasting is more widespread tend to be farther } \\
\text { away from the Quadrant. }\end{array}$ \\
\hline
\end{tabular}

Appendix C lists all the metrics that showed some statistical significance - rejection of the null hypothesis with at least $90 \%$ confidence $\left(P\left(H_{0}\right)=0.1\right)$. See Appendix $D$ for a list of complete definitions and original sources for these statistically significant metrics.

Figures 5-1 and 5-2 and serve to better illustrate the correlation between present-day Distance From the Quadrant a given metric: 
- Figure 5-1 is a plot of Distance From the Quadrant vs. Contraceptive Prevalence Rate, using the country ranks as units on both axes. Note that the two dimensions of the Global Sustainability Quadrant - HDI and EF Index - are combined into one dimension: distance, represented on the horizontal axis.

\section{Figure 5-1: Contraceptive Prevalence Rate (CPR) vs. Present-day Distance From the Quadrant (country ranks)}

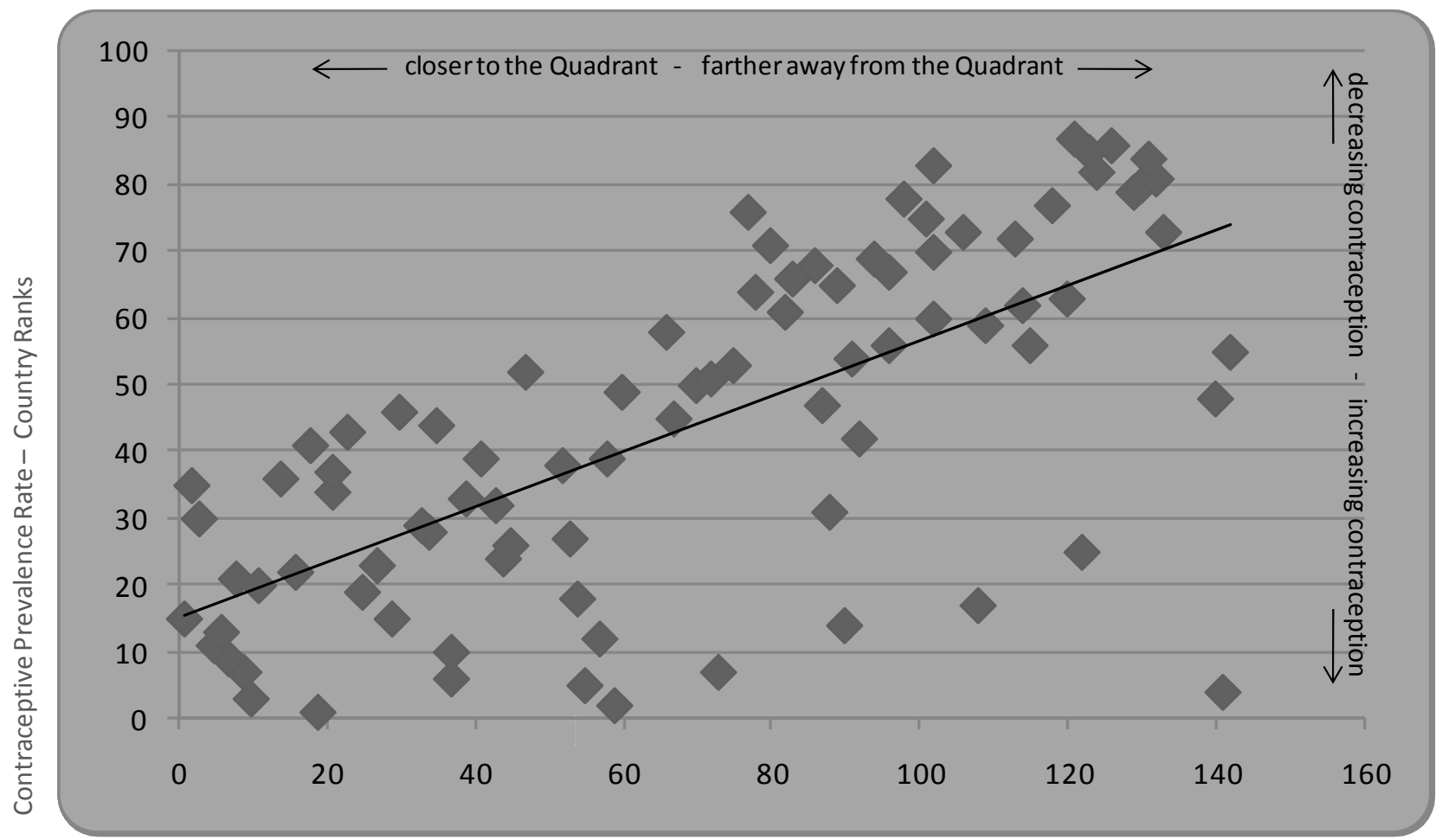

$n=87$ countries

$\mathrm{R}=\mathbf{0 . 6 8 6}$

$\mathrm{P}\left(\mathrm{H}_{0}\right)<0.001$

Countries where the \% of married women aged 15-49 practicing contraception is greater tend to be closer to the Quadrant.

Note: The most recent available measures for Contraceptive Prevalence Rate come from the late 1990s.

Distance From the Sustainability Quadrant - Country Ranks

Source: Created by the author. Data from: Global Footprint Network, 2008; UNDP, 2008; World Bank SIMA and WDI online. 
- Figure 5-2 actually uses the three dimensions separately - with HDI and EF per capita as the horizontal and vertical axes, respectively, and CPR represented with circle size (small circles = low CPR \%). Each circle represents a country; note that countries that appear closer to the Quadrant tend to be larger (higher CPR \%).

Figure 5-2: Contraceptive Prevalence Rate (CPR) - Present-day Distance From the Quadrant

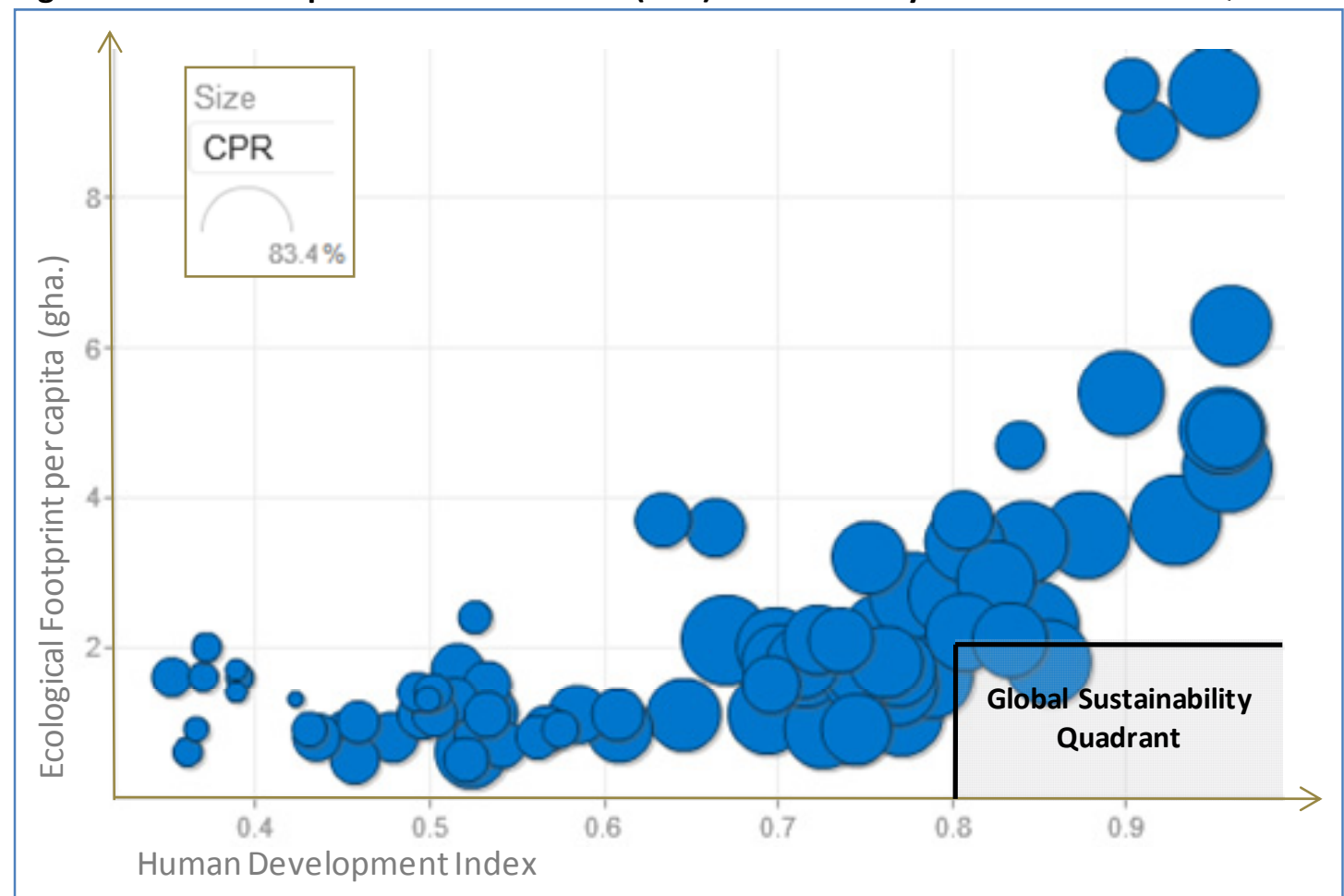

Note: The Figure does not use ranks, but the actual HDI, EF per capita, and CPR values as units. Source: Created by the author using Google Motion Chart and MS Power Point. Data from: Global Footprint Network, 2008; UNDP, 2008; World Bank SIMA and WDI online. 


\subsubsection{Long-Term Correlations with the Highest Statistical Significance}

Table 5-2 lists those metrics that showed the highest statistical significance, $\mathrm{P}\left(\mathrm{H}_{0}\right)=<0.001$, in the long-term (1980 to 2005) Movement Towards the Quadrant analysis. They are ranked according to their Pearson correlation coefficient $(R)$ value, from strongest to weakest correlation. The Interpretation column explains the meaning of the correlation, and occasionally offers a merely speculative possible explanation for it. Arriving at more concrete and reliable explanations for the correlations is out of the scope of this work, but it does constitute an interesting opportunity for further research.

Table 5-2: Long-Term (1980 to 2005) Correlations with the Highest Statistical Significance, $\underline{P}\left(\mathrm{H}_{0}\right)=<0.001$

$\mathrm{n}=$ number of pairs of data (countries).

$\mathrm{R}=$ Pearson moment correlation coefficient.

Source: Created by the author. See Section 4.5 for data sources.

\begin{tabular}{|r|l|l|l|l|}
\hline Rank & \multicolumn{1}{|c|}{ Metric } & $\mathbf{n}$ & $\mathbf{R}$ & \multicolumn{1}{c|}{ Interpretation } \\
\hline 1 & $\begin{array}{l}\text { Meat Consumption: Per } \\
\text { capita (Kg. per person) }\end{array}$ & 67 & $(0.401)$ & $\begin{array}{l}\text { As meat consumption increases in time, } \\
\text { the country tends to move away from the } \\
\text { Quadrant. This can be explained by the } \\
\text { high footprint associated with meat } \\
\text { production. }\end{array}$ \\
\hline 2 & $\begin{array}{l}\text { EF: Built-up land } \\
\text { footprint - \% of total } \\
\text { ecological footprint }\end{array}$ & 69 & $\begin{array}{l}\text { As the area defined as built-up land } \\
\text { increases its share in a country's total } \\
\text { ecological footprint, the country tends to } \\
\text { move towards the Quadrant. This could } \\
\text { be viewed as a sign of urbanization, } \\
\text { which could be associated with resource } \\
\text { efficiency; or it could also mean that } \\
\text { other components of the ecological } \\
\text { footprint are decreasing their share in the } \\
\text { total - most likely the carbon footprint, } \\
\text { which shows an inverse correlation with } \\
\text { Movement Towards the Quadrant. }\end{array}$ \\
\hline
\end{tabular}

Appendix $\mathrm{C}$ lists all the metrics that showed some statistical significance - rejection of the null hypothesis with at least $90 \%$ confidence $\left(P\left(H_{0}\right)=0.1\right)$. See Appendix $D$ for a list of complete definitions and original sources for these statistically significant metrics.

Figures 5-3 and 5-4 serve to better illustrate the correlation between long-term (1980 to 2005) Movement Towards the Quadrant and a given metric:

- Figure 5-3 is a plot of Movement Towards the Quadrant vs. change in Meat Consumption per capita, using the country ranks as units on both axes. Note that the 
two dimensions of the Quadrant - HDI and EF Index - are combined into one dimension: movement, represented on the horizontal axis.

- Figure 5-4 actually uses the three dimensions separately - with HDI and EF per capita as the horizontal and vertical axes, respectively, and change in meat consumption per capita represented with circle size. Each circle represents a country; countries that increased their meat consumption per capita in the period are larger in size, whereas those which decreased their consumption are smaller. The trajectory through time for the top and bottom movers (for meat consumption) is highlighted. The Figure does not use ranks but actual values as units.

Notice that, of the 10 countries highlighted in Figure 5-4, only 3 (Kuwait, Denmark, and Brazil) exhibit behavior contrary to the tendency described by the correlation. 
Figure 5-3: Meat Consumption per capita - Long-term Movement (1980 to 2005)

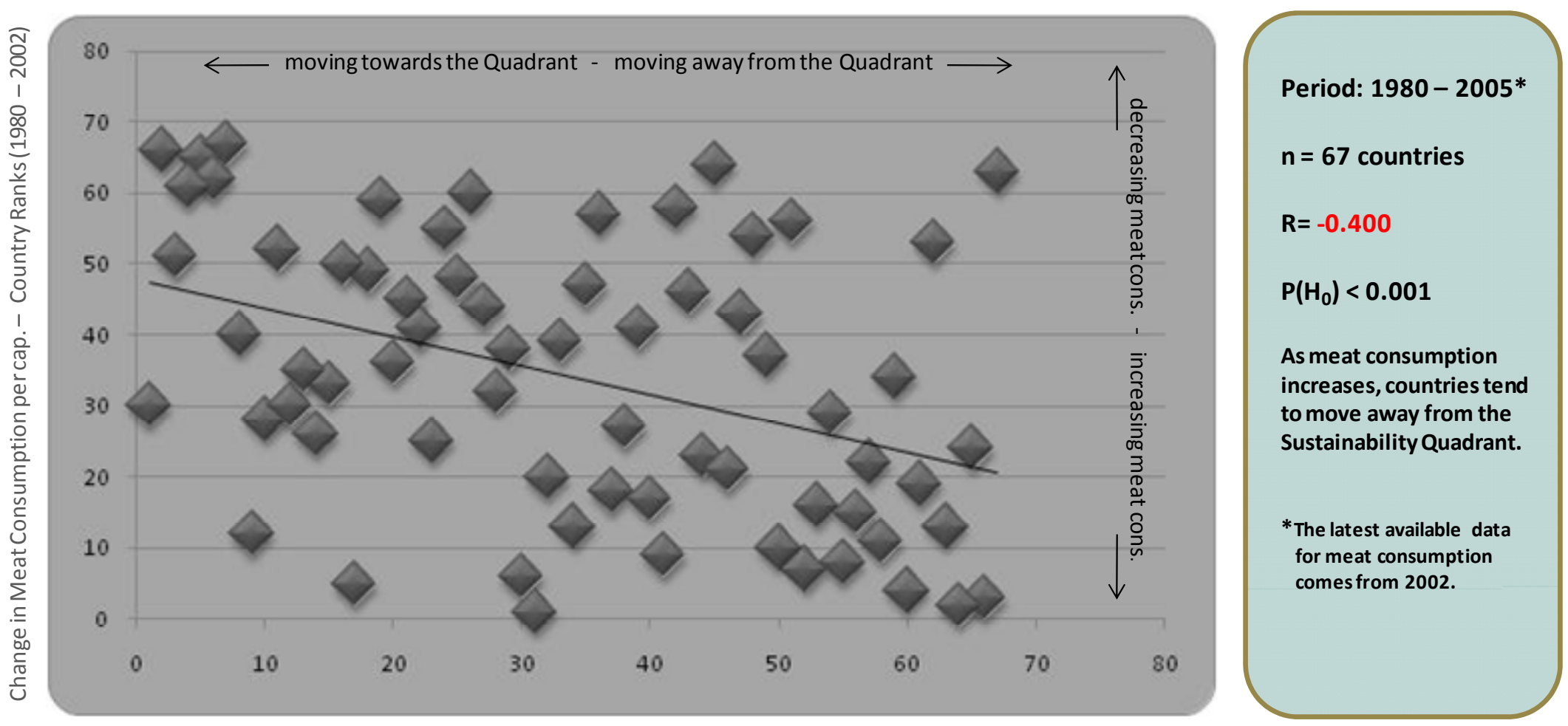

Movement towards the Sustainability Quadrant - Country Ranks (1980 - 2005)

Source: Created by the author. Data from: Global Footprint Network, 2008; UNDP, 2008; FAO, 2004. 
Figure 5-4: Meat Consumption per capita - Top Movers, Long-term (1980 to 2005)
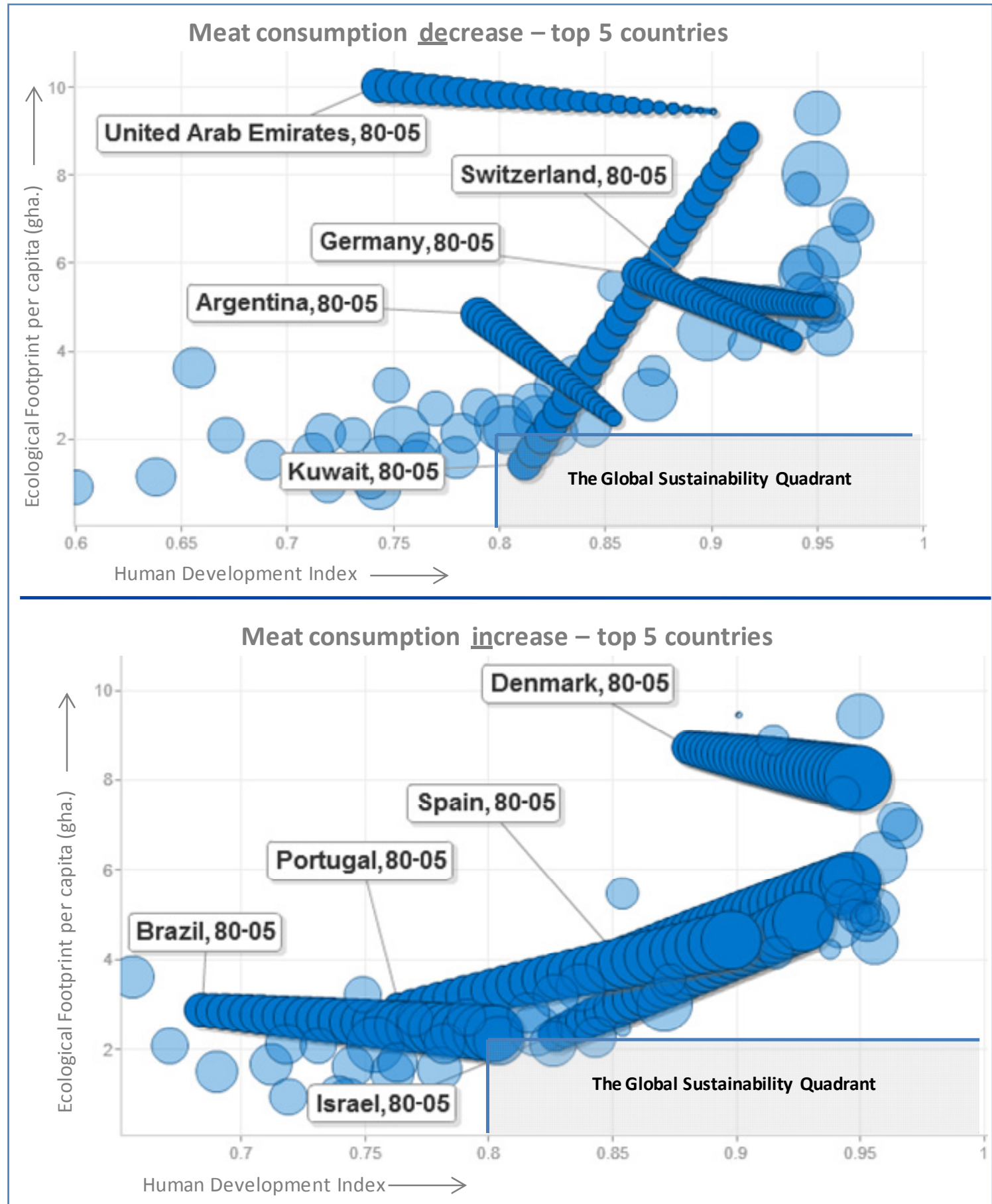

Notes:Period: 1980 - 2005 (the most recent data available for meat consumption comes from 2002) Countries that decrease their meat consumption tend to move towards the Quadrant.

Countries that increase their meat consumption tend to move away from the Quadrant. Source: Created by the author using Google Motion Chart and MS Power Point. Data from: Global Footprint Network, 2008; UNDP, 2008; FAO, 2004. 


\subsubsection{Medium-Term Correlations with the Highest Statistical Significance}

Table 5-3 lists the only metric that showed the highest possible statistical significance, $\mathrm{P}\left(\mathrm{H}_{0}\right)=$ $<0.001$, in the medium-term (1990 to 2005) Movement Towards the Quadrant analysis. The Interpretation column explains the meaning of the correlation, and offers a merely speculative possible explanation for it. Arriving at a more concrete and reliable explanation for the correlation is out of the scope of this work, but it does constitute an interesting opportunity for further research.

Table 5-3: Medium-Term (1990 to 2005) Correlations with the Highest Statistical Significance, $\underline{P}\left(\mathrm{H}_{0}\right)=<0.001$

$\mathrm{n}=$ number of pairs of data (countries).

$\mathrm{R}=$ Pearson moment correlation coefficient.

Source: Created by the author. See Section 4.5 for data sources.

\begin{tabular}{|l|c|c|l|}
\hline \multicolumn{1}{|c|}{ Metric } & $\mathbf{n}$ & $\mathbf{R}$ & \multicolumn{1}{c|}{ Interpretation } \\
\hline $\begin{array}{l}\text { Demographics: Life } \\
\text { expectancy at birth, both } \\
\text { sexes (years) }\end{array}$ & 83 & 0.372 & $\begin{array}{l}\text { As a country's average life expectancy } \\
\text { increases, it tends to move towards the } \\
\text { Quadrant. This is one of the components of } \\
\text { the HDI, so the correlation is not surprising. }\end{array}$ \\
\hline
\end{tabular}

Appendix $\mathrm{C}$ lists all the metrics that showed some statistical significance - rejection of the null hypothesis with at least $90 \%$ confidence $\left(P\left(H_{0}\right)=0.1\right)$. See Appendix $D$ for a list of complete definitions and original sources for these statistically significant metrics.

\subsubsection{Short-Term Correlations with the Highest Statistical Significance}

Table 5-4 lists those metrics that showed the highest statistical significance, $\mathrm{P}\left(\mathrm{H}_{0}\right)=<0.001$, in the short-term (2000 to 2005) Movement Towards the Quadrant analysis. They are ranked according to their Pearson correlation coefficient $(R)$ value, from strongest to weakest correlation. The Interpretation column explains the meaning of the correlation, and occasionally offers a merely speculative possible explanation for it. Arriving at more concrete and reliable explanations for the correlations is out of the scope of this work, but it does constitute an interesting opportunity for further research. 
Table 5-4: Short-Term (2000 to 2005) Correlations with the Highest Statistical Significance, $\mathrm{P}\left(\mathrm{H}_{0}\right)=<0.001$ $\mathrm{n}=$ number of pairs of data (countries).

$\mathrm{R}=$ Pearson moment correlation coefficient.

Source: Created by the author. See Section 4.5 for data sources.

\begin{tabular}{|c|c|c|c|c|}
\hline Rank & Metric & $\mathbf{n}$ & $\mathbf{R}$ & Interpretation \\
\hline 1 & $\begin{array}{l}\text { Forest Extent: Natural forest } \\
\text { area (percent of total area) }\end{array}$ & 137 & $(0.423)$ & $\begin{array}{l}\text { As the natural forest area increases its share in a country's total land } \\
\text { area, the country tends to move away from the Quadrant. This } \\
\text { relationship contradicts common conceptions about sustainable } \\
\text { development. Possible explanations include: countries that are } \\
\text { reforesting are doing so precisely because they are acknowledging } \\
\text { their unsustainable ways; others who are deforesting are achieving } \\
\text { "development" at the expense of the natural capital - like incurring } \\
\text { in debt, this practice eventually will catch up with them. }\end{array}$ \\
\hline 2 & $\begin{array}{l}\text { EF: Built-up land footprint - \% of } \\
\text { total ecological footprint }\end{array}$ & 121 & 0.409 & $\begin{array}{l}\text { As the area defined as built-up land increases its share in a country's } \\
\text { total ecological footprint, the country tends to move towards the } \\
\text { Quadrant. This could be viewed as a sign of resource efficiency } \\
\text { associated with urbanization; or it could also mean that other } \\
\text { components of the ecological footprint are decreasing their share in } \\
\text { the total more rapidly - most likely the carbon footprint, which } \\
\text { shows an inverse correlation with Movement Towards the Quadrant. }\end{array}$ \\
\hline
\end{tabular}


Table 5-4 (continued)

\begin{tabular}{|c|c|c|c|c|}
\hline Rank & Metric & $\mathbf{n}$ & $\mathbf{R}$ & Interpretation \\
\hline 3 & $\begin{array}{l}\text { GDP per capita, PPP, current } \\
\text { international dollars }\end{array}$ & 121 & $(0.403)$ & $\begin{array}{l}\text { As GDP Per capita increases, the country tends to move away from } \\
\text { the Quadrant. This could be related to an increased consumption of } \\
\text { resources brought upon by the population's growing purchasing } \\
\text { power. It would be worth to explore where the GDP stops impacting } \\
\text { quality of life; a plot of GDP vs. Life Expectancy would show that this } \\
\text { relationship is one of "diminishing returns." Furthermore, the link } \\
\text { between economic development and environmental quality has } \\
\text { been thoroughly explored by the proponents of the Environmental } \\
\text { Kuznets Curve hypothesis; }{ }^{25} \text { however, the relationship between } \\
\text { economic development and ecological footprint does not appear to } \\
\text { fit that hypothesis. }\end{array}$ \\
\hline 4 & $\begin{array}{l}\text { Demographics: Life expectancy } \\
\text { at birth, both sexes (years) }\end{array}$ & 121 & 0.373 & $\begin{array}{l}\text { As a country's average life expectancy increases, it tends to move } \\
\text { towards the Quadrant. This is one of the components of the HDI, so } \\
\text { the correlation is not surprising. }\end{array}$ \\
\hline 5 & $\begin{array}{l}\text { Demographics: Total fertility } \\
\text { rate (children per woman) }\end{array}$ & 121 & $(0.364)$ & $\begin{array}{l}\text { As more people are being born within a country, it tends to move } \\
\text { away from the Quadrant. This may indicate increased pressure on } \\
\text { resources, associated with overpopulation, which may lead to their } \\
\text { unsustainable use; it could also be attributed to the fertility rate's } \\
\text { negative association with the other components of the HDI. }\end{array}$ \\
\hline 6 & $\begin{array}{l}\text { Public Health: Per capita total } \\
\text { expenditure on health } \\
\text { (international dollars per } \\
\text { person) }\end{array}$ & 121 & $(0.356)$ & $\begin{array}{l}\text { As average expenses in health care increase, the country tends to } \\
\text { move away from the Quadrant. This is not surprising, as an } \\
\text { unhealthy population is likely in no good position to achieve } \\
\text { sustainable development. }\end{array}$ \\
\hline
\end{tabular}

${ }^{25}$ The theory behind the Environmental Kuznets curve is that an inverted-U relationship can be made between environmental degradation and economic development. This means that as a society moves toward economic development, its environmental quality diminishes, but after a certain point, it begins to improve, as a sign that greater development brings upon environmental stewardship. 
Table 5-4 (continued)

\begin{tabular}{|c|c|c|c|c|}
\hline Rank & Metric & $\mathbf{n}$ & $\mathbf{R}$ & Interpretation \\
\hline 7 & $\begin{array}{l}\text { Access to Information: Cellular } \\
\text { mobile telephone subscribers } \\
\text { per } 1000 \text { people }\end{array}$ & 121 & $(0.341)$ & $\begin{array}{l}\text { As cellular phones become more widespread in a country, it tends to } \\
\text { move away from the Quadrant. This could be a sign of a } \\
\text { population's growing purchasing power, related in turn to increased } \\
\text { consumption of resources. }\end{array}$ \\
\hline 8 & $\begin{array}{l}\text { Total external debt (current US\$ } \\
\text { per person) }\end{array}$ & 92 & (0.339) & $\begin{array}{l}\text { As its external debt grows in time, a country tends to move away } \\
\text { from the Quadrant. A debt-free country should be better positioned } \\
\text { to achieve sustainable development. }\end{array}$ \\
\hline 9 & $\begin{array}{l}\text { Population density (people per } \\
\text { square } \mathrm{km}^{2} \text { ) }\end{array}$ & 119 & 0.339 & $\begin{array}{l}\text { As population density increases in a country, the country tends to } \\
\text { move towards the Quadrant. This correlation is puzzling; one } \\
\text { possible explanation could lie in the population-imposed constraints } \\
\text { on the available resources, which can force their more efficient use. }\end{array}$ \\
\hline 10 & $\begin{array}{l}\text { Civil Society: Density of } \\
\text { international non-governmental } \\
\text { organizations with membership } \\
\text { (INGOs with membership per } \\
\text { million population) }\end{array}$ & 121 & $(0.337)$ & $\begin{array}{l}\text { As INGOs proliferate within a country, it tends to move away from } \\
\text { the Quadrant. Such proliferation may reflect a response to the } \\
\text { country's need to reverse its path and start moving towards } \\
\text { sustainability. }\end{array}$ \\
\hline 11 & $\begin{array}{l}\text { Demographics: Crude birth rate } \\
\text { (births per } 1,000 \text { people) }\end{array}$ & 121 & $(0.333)$ & $\begin{array}{l}\text { As more people are being born within a country, it tends to move } \\
\text { away from the Quadrant. This may indicate increased pressure on } \\
\text { resources, associated with overpopulation, which may lead to their } \\
\text { unsustainable use; it could also be attributed to the fertility rate's } \\
\text { negative association with the other components of the HDI. }\end{array}$ \\
\hline 12 & $\begin{array}{l}\text { Trade in Forest Products: } \\
\text { Imports, value (US dollars per } \\
\text { person) }\end{array}$ & 120 & $(0.323)$ & $\begin{array}{l}\text { As a country imports more forest products, the country tends to } \\
\text { move away from the Quadrant. This could reflect a need for } \\
\text { resources that surpasses the country's own production capacity - } \\
\text { either high consumption, low local stocks, or both. }\end{array}$ \\
\hline
\end{tabular}


Table 5-4 (continued)

\begin{tabular}{|c|c|c|c|c|}
\hline Rank & Metric & $\mathbf{n}$ & $\mathbf{R}$ & Interpretation \\
\hline 13 & $\begin{array}{l}\text { Energy Consumption: Total } \\
\text { energy consumption per capita } \\
\text { (kgoe per person) }\end{array}$ & 105 & $(0.323)$ & $\begin{array}{l}\text { As energy consumption increases, the country tends to move away } \\
\text { from the Quadrant. Note that this metric does not distinguish } \\
\text { between different sources of electricity. }\end{array}$ \\
\hline 14 & $\begin{array}{l}\text { EF: Cropland footprint - \% of } \\
\text { total ecological footprint }\end{array}$ & 121 & 0.318 & $\begin{array}{l}\text { As the cropland area increases its share in a country's total ecological } \\
\text { footprint, the country tends to move towards the Quadrant. This } \\
\text { could be associated with a reduction in the share of other } \\
\text { components of the ecological footprint - most likely the carbon } \\
\text { footprint, which shows an inverse correlation with Movement } \\
\text { Towards the Quadrant. }\end{array}$ \\
\hline 15 & $\begin{array}{l}\text { Children's Health: Infant } \\
\text { mortality rate (deaths per } 1,000 \\
\text { live births) }\end{array}$ & 121 & $(0.314)$ & $\begin{array}{l}\text { As infant mortality increases, the country tends to move away from } \\
\text { the Quadrant. Obviously, high infant mortality means that the } \\
\text { human requirements of sustainable development are not being met. }\end{array}$ \\
\hline 16 & $\begin{array}{l}\text { GDP: Official exchange rate } \\
\text { (local currency / US dollars) }\end{array}$ & 120 & 0.310 & $\begin{array}{l}\text { A country's official exchange rate "is calculated as an annual average } \\
\text { based on monthly averages and is expressed as the number of local } \\
\text { currency units equivalent to a U.S. dollar." Quoted from the Earth } \\
\text { Trends portal. } \\
\text { As a country's currency decreases its value respective to the US } \\
\text { dollar, it tends to move towards the Quadrant. Perhaps this could be } \\
\text { explained by constraints in the population's spending power, which } \\
\text { could lower their consumption patterns. }\end{array}$ \\
\hline
\end{tabular}


Table 5-4 (continued)

\begin{tabular}{|c|c|c|c|c|}
\hline Rank & Metric & $\mathbf{n}$ & $\mathbf{R}$ & Interpretation \\
\hline 17 & $\begin{array}{l}\text { Forest Extent: Total forest area } \\
\text { (percent of total area) }\end{array}$ & 142 & $(0.310)$ & $\begin{array}{l}\text { As the total forest area increases its share in a country's total land } \\
\text { area, the country tends to move away from the Quadrant. This } \\
\text { relationship contradicts common conceptions about sustainable } \\
\text { development. Possible explanations include: countries that are } \\
\text { reforesting are doing so precisely because they are acknowledging } \\
\text { their unsustainable ways; others who are deforesting are achieving } \\
\text { "development" at the expense of the natural capital - like incurring } \\
\text { in debt, this practice eventually will catch up with them. }\end{array}$ \\
\hline 18 & $\begin{array}{l}\text { Politics and Freedom: } \\
\text { Regulatory Quality Index (Index: } \\
-2.5 \text { worst governance, } 0 \\
\text { average, } 2.5 \text { best governance) }\end{array}$ & 121 & $(0.306)$ & $\begin{array}{l}\text { The Regulatory Quality Index is a measure of "the incidence of } \\
\text { market unfriendly policies such as price controls or inadequate bank } \\
\text { supervision, as well as perceptions of the burdens imposed by } \\
\text { excessive regulation in areas such as foreign trade and business } \\
\text { development." It attempts to describe the degree to which } \\
\text { governments create an atmosphere that encourages trade and } \\
\text { foreign investment. Quoted from the Earth Trends portal. } \\
\text { As a country encourages trade and foreign investment, it tends to } \\
\text { move away from the Quadrant. A possible explanation for this is the } \\
\text { overexploitation of local resources that unregulated markets can } \\
\text { sometimes foster. }\end{array}$ \\
\hline 19 & $\begin{array}{l}\text { EF: Carbon footprint - \% of total } \\
\text { ecological footprint }\end{array}$ & 121 & $(0.303)$ & $\begin{array}{l}\text { As the carbon footprint increases its share in a country's total } \\
\text { ecological footprint, the country tends to move away from the } \\
\text { Quadrant. }\end{array}$ \\
\hline 20 & $\begin{array}{l}\text { Children's Health: Under- } 5 \\
\text { mortality rate (deaths per } 1,000 \\
\text { live births) }\end{array}$ & 121 & $(0.295)$ & $\begin{array}{l}\text { As infant mortality increases, the country tends to move away from } \\
\text { the Quadrant. Obviously, high infant mortality means that the } \\
\text { human requirements of sustainable development are not being met. }\end{array}$ \\
\hline
\end{tabular}




\section{Table 5-4 (continued)}

\begin{tabular}{|r|l|c|c|l|}
\hline Rank & \multicolumn{1}{|c|}{ Metric } & $\mathbf{n}$ & $\mathbf{R}$ & \multicolumn{1}{|c|}{ Interpretation } \\
\hline 21 & $\begin{array}{l}\text { Agricultural Production Indices: } \\
\begin{array}{l}\text { Food production per capita } \\
\text { index (\% of 1999-2001 avg. food } \\
\text { production per capita) }\end{array}\end{array}$ & 121 & (0.292) & $\begin{array}{l}\text { As a country increases its food production, it tends to move away } \\
\text { from the Quadrant. On the contrary, countries that are high food } \\
\text { producers tend to be close to the Quadrant in the present-day. }\end{array}$ \\
\hline
\end{tabular}

Appendix $\mathrm{C}$ lists all the metrics that showed some statistical significance - rejection of the null hypothesis with at least $90 \%$ confidence $\left(P\left(H_{0}\right)=0.1\right)$. See Appendix $D$ for a list of complete definitions and original sources for these statistically significant metrics. 


\subsection{Metrics with Statistical Significance in Multiple Periods}

Some metrics show correlations not of the highest statistical significance, but significant nevertheless. Table 5-5 lists those metrics that were found to have some degree of statistical significance - rejection of the null hypothesis with at least $90 \%$ confidence $\left(P\left(H_{0}\right)=0.1\right)$ - on more than one term analyzed, be it long, medium, short-term Movement, or present-day Distance.

Especially noteworthy are those metrics that exhibit opposite types of correlation between historical movement and present-day distance (e.g., negative correlation in the long-term, and positive correlation in the present-day); these metrics are highlighted on the Table. The Interpretation column explains the meaning of the correlation, and occasionally offers a merely speculative possible explanation for it. Arriving at more concrete and reliable explanations for the correlations is out of the scope of this work, but it does constitute an interesting opportunity for further research. 


\section{Table 5-5: Metrics with Statistical Significance on more than One Term}

$\mathrm{n}=$ number of pairs of data (countries).

$\mathrm{R}=$ Pearson moment correlation coefficient.

$\mathrm{P}\left(\mathrm{H}_{0}\right)=$ Probability for the Null Hypothesis (i.e., no correlation).

Highlighted metrics exhibit opposite types of correlation between historical movement and present-day distance.

Source: Created by the author. See Section 4.5 for data sources.

\begin{tabular}{|c|c|c|c|c|c|c|c|c|c|c|c|c|c|}
\hline \multirow{3}{*}{ Metric } & \multicolumn{9}{|c|}{ Movement Towards the Quadrant } & \multirow{2}{*}{\multicolumn{3}{|c|}{$\begin{array}{c}\text { Present-day } \\
\text { Distance from } \\
\text { Quadrant }\end{array}$}} & \multirow{3}{*}{ Interpretation } \\
\hline & \multicolumn{3}{|c|}{ Long -term (80-05) } & \multicolumn{3}{|c|}{ Med.-term (90-05) } & \multicolumn{3}{|c|}{ Short-term (00-05) } & & & & \\
\hline & $\mathrm{n}$ & $\mathbf{R}$ & $\mathrm{P}\left(\mathrm{H}_{0}\right)$ & $\mathbf{n}$ & $\mathbf{R}$ & $\mathrm{P}\left(\mathrm{H}_{0}\right)$ & $\mathbf{n}$ & $\mathbf{R}$ & $\mathbf{P}\left(\mathbf{H}_{0}\right)$ & $\mathbf{n}$ & $\mathbf{R}$ & $P\left(H_{0}\right)$ & \\
\hline $\begin{array}{l}\text { Access to } \\
\text { Information: } \\
\text { Cellular } \\
\text { mobile } \\
\text { telephone } \\
\text { subscribers } \\
\text { per } 1000 \\
\text { people }\end{array}$ & 67 & $(0.313)$ & 0.01 & & $\begin{array}{l}\text { Not stati } \\
\text { signifi }\end{array}$ & & 121 & $(0.341)$ & $<0.001$ & & $\begin{array}{l}\text { Not statist } \\
\text { significa }\end{array}$ & & $\begin{array}{l}\text { As cellular phones become } \\
\text { more widespread in a } \\
\text { country, especially in the last } \\
\text { few years, it tends to move } \\
\text { away from the Quadrant. } \\
\text { This could be a sign of a } \\
\text { population's growing } \\
\text { purchasing power, related in } \\
\text { turn to increased } \\
\text { consumption of resources. }\end{array}$ \\
\hline $\begin{array}{l}\text { Agricultural } \\
\text { Production } \\
\text { Indices: Food } \\
\text { production } \\
\text { per capita } \\
\text { index (\% of } \\
1999-2001 \\
\text { avg. food } \\
\text { production } \\
\text { per capita) }\end{array}$ & & $\begin{array}{l}\text { Not statist } \\
\text { significa }\end{array}$ & & & $\begin{array}{l}\text { Not stati } \\
\text { signifi }\end{array}$ & & 121 & $(0.292)$ & 0.001 & 142 & 0.375 & $<0.001$ & $\begin{array}{l}\text { As a country increases its } \\
\text { food production, it tends to } \\
\text { move away from the } \\
\text { Quadrant, whereas countries } \\
\text { that are high food producers } \\
\text { tend to be closer to the } \\
\text { Quadrant in the present-day } \\
\text { (this later correlation is a bit } \\
\text { stronger). When examining } \\
\text { the causes for this, issues } \\
\text { such as population growth } \\
\text { and food security should not } \\
\text { be overlooked. }\end{array}$ \\
\hline
\end{tabular}


Table 5-5 (continued)

\begin{tabular}{|c|c|c|c|c|c|c|c|c|c|c|c|c|c|}
\hline \multirow{3}{*}{ Metric } & \multicolumn{9}{|c|}{ Movement Towards the Quadrant } & \multirow{2}{*}{\multicolumn{3}{|c|}{$\begin{array}{l}\text { Present-day } \\
\text { Distance from } \\
\text { Quadrant }\end{array}$}} & \multirow{3}{*}{ Interpretation } \\
\hline & \multicolumn{3}{|c|}{ Long -term (80-05) } & \multicolumn{3}{|c|}{ Med.-term (90-05) } & \multicolumn{3}{|c|}{ Short-term (00-05) } & & & & \\
\hline & $\mathrm{n}$ & $\mathbf{R}$ & $\mathrm{P}\left(\mathrm{H}_{0}\right)$ & $\mathbf{n}$ & $\mathbf{R}$ & $\mathbf{P}\left(\mathrm{H}_{0}\right)$ & $n$ & $\mathbf{R}$ & $\mathrm{P}\left(\mathrm{H}_{0}\right)$ & $n$ & $\mathbf{R}$ & $\mathbf{P}\left(\mathrm{H}_{0}\right)$ & \\
\hline $\begin{array}{l}\text { Children's } \\
\text { Health: Infant } \\
\text { mortality rate } \\
\text { (deaths per } \\
1,000 \text { live } \\
\text { births) }\end{array}$ & 69 & $(0.251)$ & $<0.05$ & 83 & $(0.310)$ & $<0.01$ & 121 & $(0.314)$ & 0.001 & & nifi & & $\begin{array}{l}\text { As infant mortality increases, } \\
\text { the country tends to move } \\
\text { away from the Quadrant. } \\
\text { Obviously, high infant } \\
\text { mortality means that the } \\
\text { human requirements of } \\
\text { sustainable development are } \\
\text { not being met. The } \\
\text { correlation is consistent on } \\
\text { all three time periods } \\
\text { analyzed for historical } \\
\text { movement. }\end{array}$ \\
\hline $\begin{array}{l}\text { Children's } \\
\text { Health: } \\
\text { Under-5 } \\
\text { mortality rate } \\
\text { (deaths per } \\
\text { 1,000 live } \\
\text { births) }\end{array}$ & 69 & $(0.254)$ & $<0.05$ & 83 & $(0.304)$ & $<0.01$ & 121 & $(0.295)$ & 0.001 & & nifi & & $\begin{array}{l}\text { As infant mortality increases, } \\
\text { the country tends to move } \\
\text { away from the Quadrant. } \\
\text { Obviously, high infant } \\
\text { mortality means that the } \\
\text { human requirements of } \\
\text { sustainable development are } \\
\text { not being met. The } \\
\text { correlation is consistent on } \\
\text { all three time periods } \\
\text { analyzed for historical } \\
\text { movement. }\end{array}$ \\
\hline
\end{tabular}


Table 5-5 (continued)

\begin{tabular}{|c|c|c|c|c|c|c|c|c|c|c|c|c|c|}
\hline \multirow{3}{*}{ Metric } & \multicolumn{9}{|c|}{ Movement Towards the Quadrant } & \multirow{2}{*}{\multicolumn{3}{|c|}{$\begin{array}{c}\text { Present-day } \\
\text { Distance from } \\
\text { Quadrant }\end{array}$}} & \multirow{3}{*}{ Interpretation } \\
\hline & \multicolumn{3}{|c|}{ Long -term (80-05) } & \multicolumn{3}{|c|}{ Med.-term (90-05) } & \multicolumn{3}{|c|}{ Short-term (00-05) } & & & & \\
\hline & $\mathrm{n}$ & $\mathbf{R}$ & $\mathrm{P}\left(\mathrm{H}_{0}\right)$ & $\mathbf{n}$ & $\mathbf{R}$ & $\mathbf{P}\left(\mathrm{H}_{0}\right)$ & $n$ & $\mathbf{R}$ & $\mathrm{P}\left(\mathrm{H}_{0}\right)$ & $n$ & $\mathbf{R}$ & $\mathrm{P}\left(\mathrm{H}_{0}\right)$ & \\
\hline $\begin{array}{l}\mathrm{CO} 2 \\
\text { Emissions per } \\
\text { capita (metric } \\
\text { tons per } \\
\text { capita) }\end{array}$ & 69 & $(0.234)$ & $<0.1$ & 82 & $(0.220)$ & $<0.05$ & 121 & $(0.165)$ & $<0.1$ & \multicolumn{3}{|c|}{$\begin{array}{l}\text { Not statistically } \\
\text { significant }\end{array}$} & $\begin{array}{l}\text { As } \mathrm{CO}_{2} \text { emissions increase, } \\
\text { the country tends to move } \\
\text { away from the Quadrant. } \\
\text { The correlation is consistent } \\
\text { on all three time periods } \\
\text { analyzed for historical } \\
\text { movement. }\end{array}$ \\
\hline $\begin{array}{l}\text { Debt: Total } \\
\text { debt service } \\
\text { (current US\$ } \\
\text { per person) }\end{array}$ & & $\begin{array}{r}\text { Not statist } \\
\text { significa }\end{array}$ & ally & & $\begin{array}{r}\text { Not statisti } \\
\text { significa }\end{array}$ & & 92 & $(0.284)$ & $<0.01$ & 109 & 0.641 & $<0.001$ & $\begin{array}{l}\text { As its debt grows in the } \\
\text { short-term, a country tends } \\
\text { to move away from the } \\
\text { Quadrant. A debt-free } \\
\text { country should be better } \\
\text { positioned to achieve } \\
\text { sustainable development. } \\
\text { Nevertheless, countries with } \\
\text { higher debts tend to be } \\
\text { closer to the Quadrant in the } \\
\text { present-day - perhaps this } \\
\text { explains how they got there } \\
\text { (by borrowing money). The } \\
\text { trend seems to make perfect } \\
\text { sense: borrowing money can } \\
\text { solve problems today, but } \\
\text { eventually turns into a } \\
\text { burden. }\end{array}$ \\
\hline
\end{tabular}


Table 5-5 (continued)

\begin{tabular}{|c|c|c|c|c|c|c|c|c|c|c|c|c|c|}
\hline \multirow{3}{*}{ Metric } & \multicolumn{9}{|c|}{ Movement Towards the Quadrant } & \multirow{2}{*}{\multicolumn{3}{|c|}{$\begin{array}{l}\text { Present-day } \\
\text { Distance from } \\
\text { Quadrant }\end{array}$}} & \multirow{3}{*}{ Interpretation } \\
\hline & \multicolumn{3}{|c|}{ Long -term (80-05) } & \multicolumn{3}{|c|}{ Med.-term (90-05) } & \multicolumn{3}{|c|}{ Short-term (00-05) } & & & & \\
\hline & $n$ & $\begin{array}{l}\mathbf{R} \\
\end{array}$ & $\mathrm{P}\left(\mathrm{H}_{0}\right)$ & $n$ & $\mathbf{R}$ & $\mathrm{P}\left(\mathrm{H}_{0}\right)$ & $n$ & $\mathbf{R}$ & $\mathrm{P}\left(\mathrm{H}_{0}\right)$ & $n$ & $\mathbf{R}$ & $\mathrm{P}\left(\mathrm{H}_{0}\right)$ & \\
\hline $\begin{array}{l}\text { Demographic } \\
\text { s: Crude birth } \\
\text { rate (births } \\
\text { per } 1,000 \\
\text { people) }\end{array}$ & & $\begin{array}{l}\text { Not stat } \\
\text { signif }\end{array}$ & & & $\begin{array}{l}\text { Jot sta } \\
\text { sign }\end{array}$ & & 121 & $(0.333)$ & $<0.001$ & 142 & $(0.275)$ & $<0.01$ & $\begin{array}{l}\text { As more people are being } \\
\text { born in a country, it tends to } \\
\text { move away from the } \\
\text { Quadrant, as well as to be } \\
\text { farther away from it in the } \\
\text { present-day. This may } \\
\text { indicate increased pressure } \\
\text { on resources, associated } \\
\text { with overpopulation, which } \\
\text { may lead to their } \\
\text { unsustainable use; it could } \\
\text { also be attributed to the } \\
\text { fertility rate's negative } \\
\text { association with the other } \\
\text { components of the HDI. }\end{array}$ \\
\hline
\end{tabular}


Table 5-5 (continued)

\begin{tabular}{|c|c|c|c|c|c|c|c|c|c|c|c|c|c|}
\hline \multirow{3}{*}{ Metric } & \multicolumn{9}{|c|}{ Movement Towards the Quadrant } & \multirow{2}{*}{\multicolumn{3}{|c|}{$\begin{array}{c}\text { Present-day } \\
\text { Distance from } \\
\text { Quadrant }\end{array}$}} & \multirow{3}{*}{ Interpretation } \\
\hline & \multicolumn{3}{|c|}{ Long -term (80-05) } & \multicolumn{3}{|c|}{ Med.-term (90-05) } & \multicolumn{3}{|c|}{ Short-term (00-05) } & & & & \\
\hline & $n$ & $\mathbf{R}$ & $\mathbf{P}\left(\mathrm{H}_{0}\right)$ & $n$ & $\mathbf{R}$ & $\mathrm{P}\left(\mathrm{H}_{0}\right)$ & $n$ & $\mathbf{R}$ & $\mathrm{P}\left(\mathrm{H}_{0}\right)$ & $n$ & $\mathbf{R}$ & $\mathbf{P}\left(\mathrm{H}_{0}\right)$ & \\
\hline $\begin{array}{l}\text { Demographic } \\
\text { s: Crude } \\
\text { death rate } \\
\text { (deaths per } \\
\text { 1,000 people) }\end{array}$ & 69 & $(0.268)$ & $<0.05$ & 83 & (0.339) & $<0.01$ & 121 & $(0.224)$ & $<0.05$ & 142 & $(0.482)$ & $<0.001$ & $\begin{array}{l}\text { As the crude death rate } \\
\text { increases, the country tends } \\
\text { to move away from the } \\
\text { Quadrant. Also, countries } \\
\text { that are closer to the } \\
\text { Quadrant in the present-day } \\
\text { tend to have a lower death } \\
\text { rate. This is not surprising, } \\
\text { since a high death rate } \\
\text { indicates that the human } \\
\text { requirements of sustainable } \\
\text { development are not being } \\
\text { met. }\end{array}$ \\
\hline $\begin{array}{l}\text { Demographic } \\
\text { s: Life } \\
\text { expectancy at } \\
\text { birth, both } \\
\text { sexes (years) }\end{array}$ & & $\begin{array}{r}\text { Not statist } \\
\text { significa }\end{array}$ & & 83 & 0.372 & $<0.001$ & 121 & 0.373 & $<0.001$ & & $\begin{array}{r}\text { Not statist } \\
\text { significa }\end{array}$ & & $\begin{array}{l}\text { As a country's average life } \\
\text { expectancy increases, it } \\
\text { tends to move towards the } \\
\text { Quadrant. This is one of the } \\
\text { components of the HDI, so } \\
\text { the correlation is expected. }\end{array}$ \\
\hline
\end{tabular}


Table 5-5 (continued)

\begin{tabular}{|c|c|c|c|c|c|c|c|c|c|c|c|c|c|}
\hline \multirow{3}{*}{ Metric } & \multicolumn{9}{|c|}{ Movement Towards the Quadrant } & \multirow{2}{*}{\multicolumn{3}{|c|}{$\begin{array}{l}\text { Present-day } \\
\text { Distance from } \\
\text { Quadrant }\end{array}$}} & \multirow{3}{*}{ Interpretation } \\
\hline & \multicolumn{3}{|c|}{ Long -term (80-05) } & \multicolumn{3}{|c|}{ Med.-term (90-05) } & \multicolumn{3}{|c|}{ Short-term (00-05) } & & & & \\
\hline & $\mathbf{n}$ & $\mathbf{R}$ & $\mathrm{P}\left(\mathrm{H}_{0}\right)$ & $\mathrm{n}$ & $\mathbf{R}$ & $\mathrm{P}\left(\mathrm{H}_{0}\right)$ & $n$ & $\mathbf{R}$ & $\mathbf{P}\left(\mathrm{H}_{0}\right)$ & $n$ & $\mathbf{R}$ & $\mathrm{P}\left(\mathrm{H}_{0}\right)$ & \\
\hline $\begin{array}{l}\text { Demographic } \\
\mathrm{s} \text { : Net } \\
\text { number of } \\
\text { migrants } \\
\text { (thousands of } \\
\text { people) }\end{array}$ & 69 & $(0.375)$ & $<0.01$ & & $\begin{array}{r}\text { Jot stat } \\
\text { signif }\end{array}$ & & & $\begin{array}{r}\text { Not stat } \\
\text { signif }\end{array}$ & & 142 & $(0.342)$ & $<0.001$ & $\begin{array}{l}\text { Countries with positive } \\
\text { figures on this metric have } \\
\text { net immigration; negative } \\
\text { figures indicate net } \\
\text { emigration. Thus, net } \\
\text { emigration is here correlated } \\
\text { with Movement Towards the } \\
\text { Quadrant, as well as with } \\
\text { present-day proximity to it. }\end{array}$ \\
\hline
\end{tabular}


Table 5-5 (continued)

\begin{tabular}{|c|c|c|c|c|c|c|c|c|c|c|c|c|c|}
\hline \multirow{3}{*}{ Metric } & \multicolumn{9}{|c|}{ Movement Towards the Quadrant } & \multirow{2}{*}{\multicolumn{3}{|c|}{$\begin{array}{c}\text { Present-day } \\
\text { Distance from } \\
\text { Quadrant }\end{array}$}} & \multirow{3}{*}{ Interpretation } \\
\hline & \multicolumn{3}{|c|}{ Long -term (80-05) } & \multicolumn{3}{|c|}{ Med.-term (90-05) } & \multicolumn{3}{|c|}{ Short-term (00-05) } & & & & \\
\hline & $n$ & $\mathbf{R}$ & $\mathbf{P}\left(\mathrm{H}_{0}\right)$ & $\mathbf{n}$ & $\mathbf{R}$ & $\mathrm{P}\left(\mathrm{H}_{0}\right)$ & $n$ & $\mathbf{R}$ & $\mathrm{P}\left(\mathrm{H}_{0}\right)$ & $n$ & $\mathbf{R}$ & $\mathbf{P}\left(\mathrm{H}_{0}\right)$ & \\
\hline $\begin{array}{l}\text { Demographic } \\
\text { s: Total } \\
\text { fertility rate } \\
\text { (children per } \\
\text { woman) }\end{array}$ & & $\begin{array}{l}\text { Not sta } \\
\text { signi }\end{array}$ & & & $\begin{array}{l}\text { Not sta } \\
\text { sign }\end{array}$ & & 121 & $(0.364)$ & $<0.001$ & 142 & (0.324) & $<0.001$ & $\begin{array}{l}\text { As more people are being } \\
\text { born within a country, it } \\
\text { tends to move away from } \\
\text { the Quadrant, as well as to } \\
\text { be farther away from it in } \\
\text { the present-day. This may } \\
\text { indicate increased pressure } \\
\text { on resources, associated } \\
\text { with overpopulation, which } \\
\text { may lead to their } \\
\text { unsustainable use; it could } \\
\text { also be attributed to the } \\
\text { fertility rate's negative } \\
\text { association with the other } \\
\text { components of the HDI. The } \\
\text { fact that this metric shows } \\
\text { correlation only in the last } \\
\text { few years may indicate that } \\
\text { we are at the point in history } \\
\text { where humanity has finally } \\
\text { reached its limits to growth. }\end{array}$ \\
\hline
\end{tabular}


Table 5-5 (continued)

\begin{tabular}{|c|c|c|c|c|c|c|c|c|c|c|c|c|c|}
\hline \multirow{3}{*}{ Metric } & \multicolumn{9}{|c|}{ Movement Towards the Quadrant } & \multirow{2}{*}{\multicolumn{3}{|c|}{$\begin{array}{c}\text { Present-day } \\
\text { Distance from } \\
\text { Quadrant }\end{array}$}} & \multirow{3}{*}{ Interpretation } \\
\hline & \multicolumn{3}{|c|}{ Long -term (80-05) } & \multicolumn{3}{|c|}{ Med.-term (90-05) } & \multicolumn{3}{|c|}{ Short-term (00-05) } & & & & \\
\hline & $n$ & $\mathbf{R}$ & $\mathrm{P}\left(\mathrm{H}_{0}\right)$ & $n$ & $\mathbf{R}$ & $\mathrm{P}\left(\mathrm{H}_{0}\right)$ & $n$ & $\mathbf{R}$ & $\mathrm{P}\left(\mathrm{H}_{0}\right)$ & $n$ & $\mathbf{R}$ & $\mathrm{P}\left(\mathrm{H}_{0}\right)$ & \\
\hline $\begin{array}{l}\text { EF: Built-up } \\
\text { land footprint } \\
\text { - \% of total } \\
\text { ecological } \\
\text { footprint }\end{array}$ & 69 & 0.398 & $<0.001$ & 83 & 0.255 & $<0.05$ & 121 & 0.409 & $<0.001$ & & nif & & $\begin{array}{l}\text { As the area defined as built- } \\
\text { up land increases its share in } \\
\text { a country's total ecological } \\
\text { footprint, the country tends } \\
\text { to move towards the } \\
\text { Quadrant. This could be } \\
\text { viewed as a sign of } \\
\text { urbanization, which could be } \\
\text { associated with resource } \\
\text { efficiency; or it could also } \\
\text { mean that other components } \\
\text { of the ecological footprint } \\
\text { are decreasing their share in } \\
\text { the total - most likely the } \\
\text { carbon footprint, which } \\
\text { shows an inverse correlation } \\
\text { with the movement towards } \\
\text { Quadrant. The correlation is } \\
\text { consistent on all three time } \\
\text { periods analyzed for } \\
\text { historical movement. }\end{array}$ \\
\hline
\end{tabular}


Table 5-5 (continued)

\begin{tabular}{|c|c|c|c|c|c|c|c|c|c|c|c|c|c|}
\hline \multirow{3}{*}{ Metric } & \multicolumn{9}{|c|}{ Movement Towards the Quadrant } & \multirow{2}{*}{\multicolumn{3}{|c|}{$\begin{array}{c}\text { Present-day } \\
\text { Distance from } \\
\text { Quadrant }\end{array}$}} & \multirow{3}{*}{ Interpretation } \\
\hline & \multicolumn{3}{|c|}{ Long -term (80-05) } & \multicolumn{3}{|c|}{ Med.-term (90-05) } & \multicolumn{3}{|c|}{ Short-term (00-05) } & & & & \\
\hline & $n$ & $\mathbf{R}$ & $\mathrm{P}\left(\mathrm{H}_{0}\right)$ & $n$ & $\mathbf{R}$ & $\mathrm{P}\left(\mathrm{H}_{0}\right)$ & $n$ & $\mathbf{R}$ & $\mathrm{P}\left(\mathrm{H}_{0}\right)$ & $n$ & $\mathbf{R}$ & $\mathrm{P}\left(\mathrm{H}_{0}\right)$ & \\
\hline $\begin{array}{l}\text { EF: Carbon } \\
\text { footprint - \% } \\
\text { of total } \\
\text { ecological } \\
\text { footprint }\end{array}$ & 69 & $(0.338)$ & $<0.01$ & 83 & $(0.322)$ & $<0.01$ & 121 & $(0.303)$ & 0.001 & 142 & 0.209 & $<0.05$ & $\begin{array}{l}\text { As the carbon footprint } \\
\text { increases its share in a } \\
\text { country's total ecological } \\
\text { footprint, the country tends } \\
\text { to move away from the } \\
\text { Quadrant. Nevertheless, } \\
\text { countries with a high share } \\
\text { of carbon footprint tend to } \\
\text { be closer to the Quadrant in } \\
\text { the present-day (although } \\
\text { this correlation is less } \\
\text { significant than the ones } \\
\text { observed historically). This } \\
\text { could be associated with a } \\
\text { particular moment in a } \\
\text { nation's path towards } \\
\text { development (see } \\
\text { Environmental Kuznet's } \\
\text { Curve hypothesis }{ }^{26} \text { ). The } \\
\text { correlation is consistent on } \\
\text { all three time periods } \\
\text { analyzed for historical } \\
\text { movement. }\end{array}$ \\
\hline
\end{tabular}

${ }^{26}$ See footnote 25 . 
Table 5-5 (continued)

\begin{tabular}{|c|c|c|c|c|c|c|c|c|c|c|c|c|c|}
\hline \multirow{3}{*}{ Metric } & \multicolumn{9}{|c|}{ Movement Towards the Quadrant } & \multirow{2}{*}{\multicolumn{3}{|c|}{$\begin{array}{c}\text { Present-day } \\
\text { Distance from } \\
\text { Quadrant }\end{array}$}} & \multirow{3}{*}{ Interpretation } \\
\hline & \multicolumn{3}{|c|}{ Long -term (80-05) } & \multicolumn{3}{|c|}{ Med.-term (90-05) } & \multicolumn{3}{|c|}{ Short-term (00-05) } & & & & \\
\hline & $\mathbf{n}$ & $\mathbf{R}$ & $\mathrm{P}\left(\mathrm{H}_{0}\right)$ & $\mathbf{n}$ & $\mathbf{R}$ & $\mathrm{P}\left(\mathrm{H}_{0}\right)$ & $\mathbf{n}$ & $\mathbf{R}$ & $\mathbf{P}\left(\mathrm{H}_{0}\right)$ & $\mathbf{n}$ & $\mathbf{R}$ & $\mathrm{P}\left(\mathrm{H}_{0}\right)$ & \\
\hline $\begin{array}{l}\text { EF: Cropland } \\
\text { footprint - \% } \\
\text { of total } \\
\text { ecological } \\
\text { footprint }\end{array}$ & 69 & 0.365 & $<0.01$ & & $\begin{array}{l}\text { Not sta } \\
\text { sign }\end{array}$ & & 121 & 0.318 & $<0.001$ & & gnif & & $\begin{array}{l}\text { As the cropland footprint } \\
\text { increases its share in a } \\
\text { country's total ecological } \\
\text { footprint, the country tends } \\
\text { to move towards the } \\
\text { Quadrant. This could be } \\
\text { associated with a reduction } \\
\text { in the share of other } \\
\text { components of the } \\
\text { ecological footprint - most } \\
\text { likely the carbon footprint, } \\
\text { which shows an inverse } \\
\text { correlation with the } \\
\text { Movement Towards the } \\
\text { Quadrant. }\end{array}$ \\
\hline
\end{tabular}


Table 5-5 (continued)

\begin{tabular}{|c|c|c|c|c|c|c|c|c|c|c|c|c|c|}
\hline \multirow{3}{*}{ Metric } & \multicolumn{9}{|c|}{ Movement Towards the Quadrant } & \multirow{2}{*}{\multicolumn{3}{|c|}{$\begin{array}{c}\text { Present-day } \\
\text { Distance from } \\
\text { Quadrant }\end{array}$}} & \multirow{3}{*}{ Interpretation } \\
\hline & \multicolumn{3}{|c|}{ Long -term (80-05) } & \multicolumn{3}{|c|}{ Med.-term (90-05) } & \multicolumn{3}{|c|}{ Short-term (00-05) } & & & & \\
\hline & $n$ & $\mathbf{R}$ & $\mathrm{P}\left(\mathrm{H}_{0}\right)$ & $n$ & $\mathbf{R}$ & $\mathrm{P}\left(\mathrm{H}_{0}\right)$ & $n$ & $\mathbf{R}$ & $\mathrm{P}\left(\mathrm{H}_{0}\right)$ & $n$ & $\mathbf{R}$ & $\mathrm{P}\left(\mathrm{H}_{0}\right)$ & \\
\hline $\begin{array}{l}\text { EF: Grazing } \\
\text { footprint - \% } \\
\text { of total } \\
\text { ecological } \\
\text { footprint }\end{array}$ & & $\begin{array}{r}\text { Not sta } \\
\text { signi }\end{array}$ & & 83 & 0.320 & $<0.01$ & 121 & 0.159 & $<0.1$ & & zni & & $\begin{array}{l}\text { As the grazing footprint } \\
\text { increases its share in a } \\
\text { country's total ecological } \\
\text { footprint, the country tends } \\
\text { to move towards the } \\
\text { Quadrant. This could be } \\
\text { associated with a reduction } \\
\text { in the share of other } \\
\text { components of the } \\
\text { ecological footprint - most } \\
\text { likely the carbon footprint, } \\
\text { which shows an inverse } \\
\text { correlation with the } \\
\text { Movement Towards the } \\
\text { Quadrant. Note that the } \\
\text { significance of this } \\
\text { correlation is lower than for } \\
\text { the other component's } \\
\text { which showed positive } \\
\text { correlation as their share of } \\
\text { the total footprint changed } \\
\text { (i.e., cropland and built-up } \\
\text { land). }\end{array}$ \\
\hline
\end{tabular}


Table 5-5 (continued)

\begin{tabular}{|c|c|c|c|c|c|c|c|c|c|c|c|c|c|}
\hline \multirow{3}{*}{ Metric } & \multicolumn{9}{|c|}{ Movement Towards the Quadrant } & \multirow{2}{*}{\multicolumn{3}{|c|}{$\begin{array}{c}\text { Present-day } \\
\text { Distance from } \\
\text { Quadrant }\end{array}$}} & \multirow{3}{*}{ Interpretation } \\
\hline & \multicolumn{3}{|c|}{ Long -term (80-05) } & \multicolumn{3}{|c|}{ Med.-term (90-05) } & \multicolumn{3}{|c|}{ Short-term (00-05) } & & & & \\
\hline & $n$ & $\mathbf{R}$ & $\mathrm{P}\left(\mathrm{H}_{0}\right)$ & $\mathbf{n}$ & $\mathbf{R}$ & $\mathrm{P}\left(\mathrm{H}_{0}\right)$ & $n$ & $\mathbf{R}$ & $\mathrm{P}\left(\mathrm{H}_{0}\right)$ & $n$ & $\mathbf{R}$ & $\mathrm{P}\left(\mathrm{H}_{0}\right)$ & \\
\hline $\begin{array}{l}\text { Education: } \\
\text { Secondary } \\
\text { school } \\
\text { gender parity } \\
\text { in gross } \\
\text { enrollment } \\
\text { (Index value; } \\
100= \\
\text { enrollment } \\
\text { equality) }\end{array}$ & & N/A & & & N/A & & 86 & 0.260 & $<0.05$ & 115 & 0.276 & $<0.01$ & $\begin{array}{l}\text { Observed in the last few } \\
\text { years, as a country increases } \\
\text { its secondary school gender } \\
\text { equality, it tends to move } \\
\text { towards the Quadrant. In } \\
\text { the present-day it also seems } \\
\text { that countries that have } \\
\text { higher gender equality in } \\
\text { secondary school are closer } \\
\text { to the quadrant. }\end{array}$ \\
\hline $\begin{array}{l}\text { Electricity } \\
\text { consumption } \\
\text { per capita } \\
\text { (kWh per } \\
\text { person) }\end{array}$ & & N/A & & 74 & $(0.226)$ & $<0.1$ & 105 & $(0.280)$ & $<0.01$ & & $\begin{array}{l}\text { Not statist } \\
\text { significa }\end{array}$ & & $\begin{array}{l}\text { As electricity consumption } \\
\text { increases, the country tends } \\
\text { to move away from the } \\
\text { Quadrant. Note that this } \\
\text { metric does not distinguish } \\
\text { between different sources of } \\
\text { electricity. }\end{array}$ \\
\hline
\end{tabular}


Table 5-5 (continued)

\begin{tabular}{|c|c|c|c|c|c|c|c|c|c|c|c|c|c|}
\hline \multirow{3}{*}{ Metric } & \multicolumn{9}{|c|}{ Movement Towards the Quadrant } & \multirow{2}{*}{\multicolumn{3}{|c|}{$\begin{array}{c}\text { Present-day } \\
\text { Distance from } \\
\text { Quadrant }\end{array}$}} & \multirow{3}{*}{ Interpretation } \\
\hline & \multicolumn{3}{|c|}{ Long -term (80-05) } & \multicolumn{3}{|c|}{ Med.-term (90-05) } & \multicolumn{3}{|c|}{ Short-term (00-05) } & & & & \\
\hline & $\mathbf{n}$ & $\mathbf{R}$ & $\mathrm{P}\left(\mathrm{H}_{0}\right)$ & $n$ & $\mathbf{R}$ & $\mathrm{P}\left(\mathrm{H}_{0}\right)$ & $n$ & $\mathbf{R}$ & $\mathrm{P}\left(\mathrm{H}_{0}\right)$ & $n$ & $\mathbf{R}$ & $\mathbf{P}\left(\mathrm{H}_{0}\right)$ & \\
\hline $\begin{array}{l}\text { Energy } \\
\text { Consumption } \\
\text { by Source: } \\
\text { Biogas and } \\
\text { liquid } \\
\text { biomass } \\
\text { (ktoe per } \\
\text { million } \\
\text { persons) }\end{array}$ & & $\mathrm{N} / \mathrm{A}$ & & 73 & $(0.210)$ & $<0.1$ & 103 & $(0.173)$ & $<0.1$ & 119 & $(0.433)$ & $<0.001$ & $\begin{array}{l}\text { As consumption of biogas } \\
\text { and liquid biomass increases, } \\
\text { the country tends to move } \\
\text { away from the Quadrant, } \\
\text { although the correlation is } \\
\text { not as strong as with total } \\
\text { energy consumption per } \\
\text { capita. Also, countries that } \\
\text { are closer to the Quadrant in } \\
\text { the present-day tend to have } \\
\text { lower biogas and biomass } \\
\text { consumption. }\end{array}$ \\
\hline $\begin{array}{l}\text { Energy } \\
\text { Consumption } \\
\text { : Residential } \\
\text { energy } \\
\text { consumption } \\
\text { per capita } \\
\text { (kgoe per } \\
\text { person) }\end{array}$ & & N/A & & 72 & $(0.307)$ & $<0.01$ & & $\begin{array}{l}\text { Not statisti } \\
\text { significa }\end{array}$ & & 119 & $(0.432)$ & $<0.001$ & $\begin{array}{l}\text { As happens with total energy } \\
\text { and total electricity } \\
\text { consumption per capita, } \\
\text { when residential electricity } \\
\text { consumption increases, the } \\
\text { country tends to move away } \\
\text { from the Quadrant. } \\
\text { Nevertheless, the other two } \\
\text { metrics show no correlation } \\
\text { in the present-day. Note } \\
\text { that this metric does not } \\
\text { distinguish between } \\
\text { different sources of } \\
\text { electricity. }\end{array}$ \\
\hline
\end{tabular}


Table 5-5 (continued)

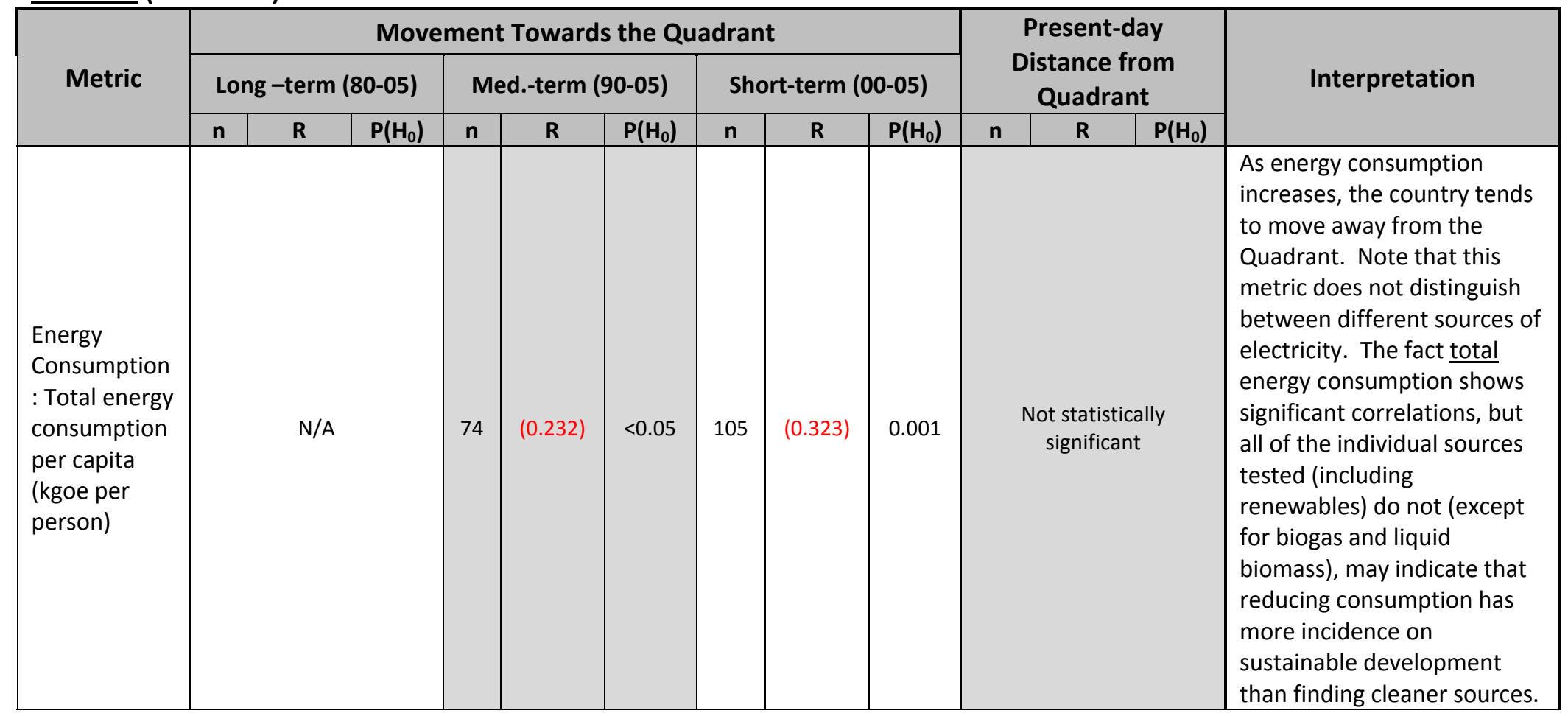


Table 5-5 (continued)

\begin{tabular}{|c|c|c|c|c|c|c|c|c|c|c|c|c|c|}
\hline \multirow{3}{*}{ Metric } & \multicolumn{9}{|c|}{ Movement Towards the Quadrant } & \multirow{2}{*}{\multicolumn{3}{|c|}{$\begin{array}{c}\text { Present-day } \\
\text { Distance from } \\
\text { Quadrant }\end{array}$}} & \multirow{3}{*}{ Interpretation } \\
\hline & \multicolumn{3}{|c|}{ Long -term (80-05) } & \multicolumn{3}{|c|}{ Med.-term (90-05) } & \multicolumn{3}{|c|}{ Short-term (00-05) } & & & & \\
\hline & $n$ & $\begin{array}{l}\mathbf{R} \\
\end{array}$ & $\mathrm{P}\left(\mathrm{H}_{0}\right)$ & $n$ & $\mathbf{R}$ & $\mathrm{P}\left(\mathrm{H}_{0}\right)$ & $\mathbf{n}$ & $\mathbf{R}$ & $\mathrm{P}\left(\mathrm{H}_{0}\right)$ & $\mathbf{n}$ & $\mathbf{R}$ & $\mathrm{P}\left(\mathrm{H}_{0}\right)$ & \\
\hline $\begin{array}{l}\text { Forest } \\
\text { (Paper) } \\
\text { Production: } \\
\text { Recovered } \\
\text { paper (metric } \\
\text { tons per } \\
\text { thousand } \\
\text { persons) }\end{array}$ & & $\begin{array}{l}\text { Not stat } \\
\text { signif }\end{array}$ & & & $\begin{array}{l}\text { Not sta } \\
\text { sign }\end{array}$ & & 80 & $(0.324)$ & $<0.01$ & 93 & (0.417) & $<0.001$ & $\begin{array}{l}\text { As the amount of recovered } \\
\text { paper increases, the country } \\
\text { tends to move away from } \\
\text { the Quadrant. Also, } \\
\text { countries that in the present } \\
\text { day are closer to the } \\
\text { Quadrant tend to recover } \\
\text { less paper. Perhaps this } \\
\text { could be explained by the } \\
\text { idea that the need to recover } \\
\text { and recycle paper arises } \\
\text { when the effects of un- } \\
\text { sustainability start to be felt. }\end{array}$ \\
\hline
\end{tabular}


Table 5-5 (continued)

\begin{tabular}{|c|c|c|c|c|c|c|c|c|c|c|c|c|c|}
\hline \multirow{3}{*}{ Metric } & \multicolumn{9}{|c|}{ Movement Towards the Quadrant } & \multirow{2}{*}{\multicolumn{3}{|c|}{$\begin{array}{l}\text { Present-day } \\
\text { Distance from } \\
\text { Quadrant }\end{array}$}} & \multirow{3}{*}{ Interpretation } \\
\hline & \multicolumn{3}{|c|}{ Long -term (80-05) } & \multicolumn{3}{|c|}{ Med.-term (90-05) } & \multicolumn{3}{|c|}{ Short-term (00-05) } & & & & \\
\hline & $n$ & $\mathbf{R}$ & $\mathrm{P}\left(\mathrm{H}_{0}\right)$ & $n$ & $\mathbf{R}$ & $\mathbf{P}\left(\mathrm{H}_{0}\right)$ & $n$ & $\mathbf{R}$ & $\mathbf{P}\left(\mathrm{H}_{0}\right)$ & $\mathbf{n}$ & $\mathbf{R}$ & $\mathbf{P}\left(\mathrm{H}_{0}\right)$ & \\
\hline $\begin{array}{l}\text { GDP per } \\
\text { capita, PPP, } \\
\text { current } \\
\text { international } \\
\text { dollars }\end{array}$ & 69 & $(0.269)$ & $<0.05$ & & $\begin{array}{l}\text { Not stat } \\
\text { signif }\end{array}$ & & 121 & $(0.403)$ & $<0.001$ & & nifi & & $\begin{array}{l}\text { As GDP Per capita increases, } \\
\text { the country tends to move } \\
\text { away from the Quadrant. } \\
\text { This could be related to an } \\
\text { increased consumption of } \\
\text { resources brought upon by } \\
\text { the population's growing } \\
\text { purchasing power. It would } \\
\text { be worth to explore where } \\
\text { the GDP stops impacting } \\
\text { quality of life; a plot of GDP } \\
\text { vs. Life Expectancy would } \\
\text { show that this relationship is } \\
\text { one of "diminishing returns." } \\
\text { This also could be associated } \\
\text { with a particular moment in } \\
\text { a nation's path towards } \\
\text { development (see } \\
\text { Environmental Kuznet's } \\
\text { Curve hypothesis }\end{array}$ \\
\hline
\end{tabular}

${ }^{27}$ See footnote 25 . 
Table 5-5 (continued)

\begin{tabular}{|c|c|c|c|c|c|c|c|c|c|c|c|c|c|}
\hline \multirow{3}{*}{ Metric } & \multicolumn{9}{|c|}{ Movement Towards the Quadrant } & \multirow{2}{*}{\multicolumn{3}{|c|}{$\begin{array}{l}\text { Present-day } \\
\text { Distance from } \\
\text { Quadrant }\end{array}$}} & \multirow{3}{*}{ Interpretation } \\
\hline & \multicolumn{3}{|c|}{ Long -term (80-05) } & \multicolumn{3}{|c|}{ Med.-term (90-05) } & \multicolumn{3}{|c|}{ Short-term (00-05) } & & & & \\
\hline & $\mathrm{n}$ & $\mathbf{R}$ & $\mathrm{P}\left(\mathrm{H}_{0}\right)$ & $n$ & $\mathbf{R}$ & $\mathbf{P}\left(\mathrm{H}_{0}\right)$ & $\mathbf{n}$ & $\mathbf{R}$ & $\mathrm{P}\left(\mathrm{H}_{0}\right)$ & $\mathbf{n}$ & $\mathbf{R}$ & $\mathrm{P}\left(\mathrm{H}_{0}\right)$ & \\
\hline $\begin{array}{l}\text { GDP: Official } \\
\text { exchange } \\
\text { rate (local } \\
\text { currency / US } \\
\text { dollars) }\end{array}$ & 69 & 0.272 & $<0.05$ & & $\begin{array}{r}\text { Not sta } \\
\text { signi }\end{array}$ & & 120 & 0.310 & 0.001 & & gni & & $\begin{array}{l}\text { A country's official exchange } \\
\text { rate "is calculated as an } \\
\text { annual average based on } \\
\text { monthly averages and is } \\
\text { expressed as the number of } \\
\text { local currency units } \\
\text { equivalent to a U.S. dollar." } \\
\text { Quoted from the Earth } \\
\text { Trends portal. } \\
\text { As a country's currency } \\
\text { decreases its value } \\
\text { respective to the US dollar, it } \\
\text { tends to move towards the } \\
\text { Quadrant. Perhaps this } \\
\text { could be explained by } \\
\text { constraints in the } \\
\text { population's spending } \\
\text { power, which could lower } \\
\text { their consumption patterns. }\end{array}$ \\
\hline
\end{tabular}


Table 5-5 (continued)

\begin{tabular}{|c|c|c|c|c|c|c|c|c|c|c|c|c|c|}
\hline \multirow{3}{*}{ Metric } & \multicolumn{9}{|c|}{ Movement Towards the Quadrant } & \multirow{2}{*}{\multicolumn{3}{|c|}{$\begin{array}{c}\text { Present-day } \\
\text { Distance from } \\
\text { Quadrant }\end{array}$}} & \multirow{3}{*}{ Interpretation } \\
\hline & \multicolumn{3}{|c|}{ Long -term (80-05) } & \multicolumn{3}{|c|}{ Med.-term (90-05) } & \multicolumn{3}{|c|}{ Short-term (00-05) } & & & & \\
\hline & $n$ & $\mathbf{R}$ & $\mathrm{P}\left(\mathrm{H}_{0}\right)$ & $\mathrm{n}$ & $\mathbf{R}$ & $\mathrm{P}\left(\mathrm{H}_{0}\right)$ & $n$ & $\mathbf{R}$ & $\mathrm{P}\left(\mathrm{H}_{0}\right)$ & $n$ & $\mathbf{R}$ & $\mathrm{P}\left(\mathrm{H}_{0}\right)$ & \\
\hline $\begin{array}{l}\text { Labor: } \\
\text { Workers' } \\
\text { remittances } \\
\text { and } \\
\text { compensatio } \\
n \text { of } \\
\text { employees, } \\
\text { received } \\
\text { (million US\$ } \\
\text { per capita) }\end{array}$ & & $\begin{array}{r}\text { Not stat } \\
\text { signif }\end{array}$ & & 62 & 0.236 & $<0.1$ & 107 & $(0.199)$ & $<0.05$ & 128 & 0.283 & $<0.001$ & $\begin{array}{l}\text { A reversal of the trend } \\
\text { between the medium and } \\
\text { the short-term is puzzling. } \\
\text { The short-term correlation is } \\
\text { more significant, and it tells } \\
\text { us that as a country receives } \\
\text { more remittance money, it } \\
\text { tends to move away from } \\
\text { the Quadrant - perhaps } \\
\text { because it needs it most. To } \\
\text { complicate matters further, } \\
\text { the correlation is reversed } \\
\text { again between the short- } \\
\text { term and the present-day, so } \\
\text { countries that receive more } \\
\text { remittance money tend to be } \\
\text { closer to the Quadrant. }\end{array}$ \\
\hline
\end{tabular}


Table 5-5 (continued)

\begin{tabular}{|c|c|c|c|c|c|c|c|c|c|c|c|c|c|}
\hline \multirow{3}{*}{ Metric } & \multicolumn{9}{|c|}{ Movement Towards the Quadrant } & \multirow{2}{*}{\multicolumn{3}{|c|}{$\begin{array}{c}\text { Present-day } \\
\text { Distance from } \\
\text { Quadrant }\end{array}$}} & \multirow{3}{*}{ Interpretation } \\
\hline & \multicolumn{3}{|c|}{ Long -term (80-05) } & \multicolumn{3}{|c|}{ Med.-term (90-05) } & \multicolumn{3}{|c|}{ Short-term (00-05) } & & & & \\
\hline & $n$ & $\mathbf{R}$ & $\mathrm{P}\left(\mathrm{H}_{0}\right)$ & $\mathbf{n}$ & $\mathbf{R}$ & $\mathrm{P}\left(\mathrm{H}_{0}\right)$ & $n$ & $\mathbf{R}$ & $\mathrm{P}\left(\mathrm{H}_{0}\right)$ & $n$ & $\mathbf{R}$ & $\mathrm{P}\left(\mathrm{H}_{0}\right)$ & \\
\hline $\begin{array}{l}\text { Meat } \\
\text { Consumption } \\
\text { : Per capita } \\
\text { (Kg. per } \\
\text { person) }\end{array}$ & 67 & $(0.401)$ & $<0.001$ & 80 & $(0.298)$ & $<0.01$ & 119 & $(0.278)$ & $<0.01$ & & nif & & $\begin{array}{l}\text { As meat consumption } \\
\text { increases in time, the } \\
\text { country tends to move away } \\
\text { from the Quadrant. This can } \\
\text { be explained by the high } \\
\text { footprint associated with } \\
\text { meat production. The } \\
\text { correlation is consistent on } \\
\text { all three time periods } \\
\text { analyzed for historical } \\
\text { movement. }\end{array}$ \\
\hline $\begin{array}{l}\text { Nutrition: } \\
\text { Calorie } \\
\text { supply per } \\
\text { capita from } \\
\text { animal } \\
\text { products } \\
\text { (kilocalories/ } \\
\text { person/day) }\end{array}$ & 68 & $(0.323)$ & $<0.01$ & & $\begin{array}{l}\text { Not statis } \\
\text { signific }\end{array}$ & & 120 & $(0.223)$ & $<0.05$ & & . & & $\begin{array}{l}\text { As a person's calorie supply } \\
\text { from animal products } \\
\text { increases in time, the } \\
\text { country tends to move away } \\
\text { from the Quadrant. This can } \\
\text { be explained by the high } \\
\text { footprint associated with } \\
\text { meat production. }\end{array}$ \\
\hline
\end{tabular}


Table 5-5 (continued)

\begin{tabular}{|c|c|c|c|c|c|c|c|c|c|c|c|c|c|}
\hline \multirow{3}{*}{ Metric } & \multicolumn{9}{|c|}{ Movement Towards the Quadrant } & \multirow{2}{*}{\multicolumn{3}{|c|}{$\begin{array}{c}\text { Present-day } \\
\text { Distance from } \\
\text { Quadrant }\end{array}$}} & \multirow{3}{*}{ Interpretation } \\
\hline & \multicolumn{3}{|c|}{ Long -term (80-05) } & \multicolumn{3}{|c|}{ Med.-term (90-05) } & \multicolumn{3}{|c|}{ Short-term (00-05) } & & & & \\
\hline & $\mathrm{n}$ & $\mathbf{R}$ & $\mathbf{P}\left(\mathrm{H}_{0}\right)$ & $n$ & $\mathbf{R}$ & $\mathrm{P}\left(\mathrm{H}_{0}\right)$ & $\mathbf{n}$ & $\mathbf{R}$ & $\mathrm{P}\left(\mathrm{H}_{0}\right)$ & $\mathbf{n}$ & $\mathbf{R}$ & $\mathrm{P}\left(\mathrm{H}_{0}\right)$ & \\
\hline $\begin{array}{l}\text { Population: } \\
\text { Above age } \\
65, \text { both } \\
\text { sexes (\% of } \\
\text { the } \\
\text { population) }\end{array}$ & & $\begin{array}{l}\text { Not stat } \\
\text { signif }\end{array}$ & $\begin{array}{l}\text { ally } \\
t\end{array}$ & & $\begin{array}{r}\text { Not sta } \\
\text { signi }\end{array}$ & & 121 & $(0.205)$ & $<0.05$ & 142 & 0.232 & $<0.01$ & $\begin{array}{l}\text { In the last few years, as the } \\
\text { population above } 65 \\
\text { increases, the country tends } \\
\text { to move away from the } \\
\text { Quadrant. Nevertheless, in } \\
\text { the present-day it seems that } \\
\text { countries that have greater } \\
\text { populations above } 65 \text { are } \\
\text { closer to the Quadrant. }\end{array}$ \\
\hline $\begin{array}{l}\text { Total } \\
\text { external debt } \\
\text { (current US\$ } \\
\text { per person) }\end{array}$ & & $\begin{array}{l}\text { Not stat } \\
\text { signif }\end{array}$ & $\begin{array}{l}\text { ally } \\
t\end{array}$ & & $\begin{array}{r}\text { Not sta } \\
\text { signi }\end{array}$ & & 92 & (0.339) & 0.001 & 109 & 0.570 & $<0.001$ & $\begin{array}{l}\text { As its debt grows in the } \\
\text { short-term, a country tends } \\
\text { to move away from the } \\
\text { Quadrant. A debt-free } \\
\text { country should be better } \\
\text { positioned to achieve } \\
\text { sustainable development. } \\
\text { Nevertheless, countries with } \\
\text { higher debts tend to be } \\
\text { closer to the Quadrant in the } \\
\text { present-day - perhaps this } \\
\text { explains how they got there } \\
\text { (by borrowing money). The } \\
\text { trend seems to make perfect } \\
\text { sense: borrowing money can } \\
\text { solve problems today, but } \\
\text { eventually turns into a } \\
\text { burden. }\end{array}$ \\
\hline
\end{tabular}


Table 5-5 (continued)

\begin{tabular}{|c|c|c|c|c|c|c|c|c|c|c|c|c|}
\hline \multirow{3}{*}{ Metric } & \multicolumn{8}{|c|}{ Movement Towards the Quadrant } & \multirow{2}{*}{\multicolumn{3}{|c|}{$\begin{array}{c}\text { Present-day } \\
\text { Distance from } \\
\text { Quadrant }\end{array}$}} & \multirow{3}{*}{ Interpretation } \\
\hline & \multicolumn{2}{|c|}{ Long -term (80-05) } & \multicolumn{3}{|c|}{ Med.-term (90-05) } & \multicolumn{3}{|c|}{ Short-term (00-05) } & & & & \\
\hline & $n$ & $\mathrm{P}\left(\mathrm{H}_{0}\right)$ & $n$ & $\mathbf{R}$ & $\mathrm{P}\left(\mathrm{H}_{0}\right)$ & $n$ & $\mathbf{R}$ & $\mathrm{P}\left(\mathrm{H}_{0}\right)$ & $n$ & $\mathbf{R}$ & $\mathbf{P}\left(\mathrm{H}_{0}\right)$ & \\
\hline $\begin{array}{l}\text { Transportatio } \\
\mathrm{n} \text { : Motor } \\
\text { gasoline } \\
\text { consumption } \\
\text { per capita } \\
\text { (Liters per } \\
\text { person) }\end{array}$ & \multicolumn{2}{|r|}{ N/A } & 73 & $(0.294)$ & $<0.05$ & 103 & $(0.211)$ & $<0.05$ & \multicolumn{3}{|c|}{$\begin{array}{l}\text { Not statistically } \\
\text { significant }\end{array}$} & $\begin{array}{l}\text { As gasoline consumption } \\
\text { increases, the country tends } \\
\text { to move away from the } \\
\text { Quadrant. }\end{array}$ \\
\hline $\begin{array}{l}\text { Urban and } \\
\text { Rural Areas: } \\
\text { Growth rate } \\
\text { of rural } \\
\text { population } \\
\text { (\%) }\end{array}$ & & $\begin{array}{l}\text { Not statistically } \\
\text { significant }\end{array}$ & 83 & 0.262 & $<0.05$ & \multicolumn{3}{|c|}{$\begin{array}{l}\text { Not statistically } \\
\text { significant }\end{array}$} & 142 & $(0.337)$ & $<0.001$ & $\begin{array}{l}\text { The medium-term trend } \\
\text { shows that, as rural } \\
\text { population grows, countries } \\
\text { tend to move towards the } \\
\text { Quadrant. Statistics show } \\
\text { that the global human } \\
\text { population is moving to the } \\
\text { city, so perhaps the city- } \\
\text { dweller's higher average } \\
\text { footprint is the cause of this } \\
\text { correlation. However, in the } \\
\text { present-day, countries that } \\
\text { are closer to the Quadrant } \\
\text { tend to have smaller rates of } \\
\text { growth for their rural } \\
\text { populations. }\end{array}$ \\
\hline
\end{tabular}




\subsection{Other Metrics Worth Mentioning}

Either for their uniqueness, or for the absence of statistical significance, some metrics are worth mentioning in this section. They pose interesting questions for those studying sustainable development.

\subsubsection{The Water Footprint}

Today, water footprints are generally below the available renewable water resources in the world - every nation is still within their fair water Earth-share per capita. Although some countries - all desert nations - are in fact relying on imported water resources (directly and indirectly), the water footprint metrics analyzed (and listed in table 4-12) did not show any significant correlation with Distance From the Sustainability Quadrant (historical data were not available). Water scarcity, however, is a problem that can and should urgently be tackled by decision-makers. Recent estimates indicate that the global average of freshwater available per capita in the year 2000 was a mere $40 \%$ of what it was in $1950 .^{28}$

\subsubsection{Ethnic, Language, and Religious Fractionalization}

National ethnic, religious, and linguistic fractionalization ${ }^{29}$ scores were tested for correlation with present-day Distance From the Quadrant (historical data were not available). As Table 5-6 shows, ethnic diversity does not seem to be a factor that influences proximity to the Sustainability Quadrant. However, it does appear that having many different religions, and even more so, many different languages spoken, has a negative impact - countries with high language and religious fractionalization tend to be farther away from the Quadrant.

Table 5-6: Fractionalization - Present-day Distance from Quadrant Correlation Results $\mathrm{n}=$ number of pairs of data (countries). $\mathrm{R}=$ Pearson moment correlation coefficient. $\mathrm{P}\left(\mathrm{H}_{0}\right)=$ Probability for the Null Hypothesis (i.e., no correlation). Source: Created by the author. See Section 4.5 for data sources.

\begin{tabular}{|l|c|c|c|}
\hline \multicolumn{1}{|c|}{ Metric } & $\mathbf{n}$ & $\mathbf{R}$ & $\mathbf{P}\left(\mathbf{H}_{\mathbf{0}}\right)$ \\
\hline Ethnic Fractionalization & 140 & $(0.196)$ & Not significant \\
\hline Language Fractionalization & 137 & $\mathbf{( 0 . 3 5 7 )}$ & $<0.001$ \\
\hline Religious Fractionalization & 141 & $\mathbf{( 0 . 2 5 2 )}$ & $<0.01$ \\
\hline
\end{tabular}

\footnotetext{
${ }^{28}$ UNDP et al., 2000.

${ }^{29}$ Fractionalization is "a measure of diversity among individuals" (Bossert, et al., 2006). Countries are given a score between 0 and 1 for ethnic, religious, and linguistic fractionalization, with higher scores indicating greater diversity.
} 


\subsubsection{Biodiversity and Forest Cover}

The National Biodiversity Index (NBI), ${ }^{30}$ which was only available for the present-day analysis, did show correlation with Distance From the Quadrant - countries with more biodiversity tend to be closer to the Quadrant -, although not of the highest significance $\left(P\left(H_{0}\right)<0.01\right)$, as Table 57 indicates).

Nevertheless, this relatively lower significance may be attributed to the fact that the Ecological Footprint methods do not allow for direct assignment of 'value' to biodiversity (see Section 3.1.2.). It should also be noted that measuring biodiversity - and in the process, distinguishing between keystone species and others - is no easy task, so obtaining reliable metrics is a challenge.

Another important consideration when dealing with this issue relates to biological corridors. It has been demonstrated that continuous areas of natural habitats can do greater good for species preservation than a larger - but fragmented - area.

Table 5-7: NBI - Present-day Distance from Quadrant Correlation Results

$n=$ number of pairs of data (countries).

$\mathrm{R}=$ Pearson moment correlation coefficient.

$\mathrm{P}\left(\mathrm{H}_{0}\right)=$ Probability for the Null Hypothesis (i.e., no correlation).

Source: Created by the author. See Section 4.5 for data sources.

\begin{tabular}{|c|c|c|c|}
\hline Metric & $\mathbf{n}$ & $\mathbf{R}$ & $\mathbf{P}\left(\mathbf{H}_{\mathbf{0}}\right)$ \\
\hline NBI (National Biodiversity Index) & 140 & 0.238 & $<0.01$ \\
\hline
\end{tabular}

In turn, the metrics Natural Forest Area and Total Forest Area percentages - available indeed for the historical analysis - showed correlations of the highest significance (in the short-term only), but in a 'negative' way: as forest cover has increased its share in a country's total land area between 2000 and 2005, the country has moved away from the Quadrant. Perhaps countries that are reforesting are doing so precisely because they are acknowledging their unsustainable ways (see Environmental Kuznet's Curve hypothesis). ${ }^{31}$

Nevertheless, other metrics that indicate a positive relationship between forest cover and sustainability for the present-day (greater cover: closer to the Quadrant) were identified. These metrics are listed in table 5-8.

Overall, the relationship between sustainable development and biodiversity/forest cover appears to indicate that countries who are deforesting are achieving 'development' at the expense of the natural capital, but after a while the negative effects of such losses start to be felt.

\footnotetext{
${ }^{30}$ The NBI is scored between 0 and 1 , "with large values corresponding to high levels of species abundance and small values reflecting low levels of species abundance." Quoted from Earth Trends.

${ }^{31}$ See footnote 25 .
} 


\section{Table 5-8: Forest Cover - Present-day Distance from Quadrant Correlation Results}

$\mathrm{n}=$ number of pairs of data (countries).

$\mathrm{R}=$ Pearson moment correlation coefficient.

$\mathrm{P}\left(\mathrm{H}_{0}\right)=$ Probability for the Null Hypothesis (i.e., no correlation).

Source: Created by the author. See Section 4.5 for data sources.

\begin{tabular}{|l|c|c|c|}
\hline \multicolumn{1}{|c|}{ Metric } & $\mathbf{n}$ & $\mathbf{R}$ & $\mathbf{P}\left(\mathbf{H}_{\mathbf{0}}\right)$ \\
\hline $\begin{array}{l}\text { Forest Extent: Forest area (current) } \\
\text { as a percent of original forest area }\end{array}$ & 134 & 0.216 & $<0.05$ \\
\hline $\begin{array}{l}\text { Forest Extent: Frontier forest area } \\
\text { as a percent of original forest area }\end{array}$ & 134 & 0.225 & 0.01 \\
\hline
\end{tabular}

\subsubsection{Energy}

Several metrics tested deal with energy consumption by source (coal, oil, gas, solar, hydro, wind, biomass, etc.). The fact that total energy consumption shows significant correlations with Movement Towards the Quadrant, but the individual sources (except biogas and liquid biomass) do not, may indicate that reducing consumption has more incidence on sustainable development than finding cleaner sources of energy.

\subsubsection{Urbanization}

Some urbanization metrics showed significant correlation in the present-day analysis. They indicate that (1) countries with higher \% of their populations in cities, and (2) countries with lower growth rates of their rural populations tend to be closer to the Quadrant. Table 5-9 lists these metrics.

Table 5-9: Urbanization- Present-day Distance from Quadrant Correlation Results

$\mathrm{n}=$ number of pairs of data (countries).

$\mathrm{R}=$ Pearson moment correlation coefficient.

$\mathrm{P}\left(\mathrm{H}_{0}\right)=$ Probability for the Null Hypothesis (i.e., no correlation).

Source: Created by the author. See Section 4.5 for data sources.

\begin{tabular}{|l|c|c|c|}
\hline \multicolumn{1}{|c|}{ Metric } & $\mathbf{n}$ & $\mathbf{R}$ & $\mathbf{P}\left(\mathbf{H}_{0}\right)$ \\
\hline $\begin{array}{l}\text { Urban and Rural Areas: Total } \\
\text { population in cities with more than } \\
100,000 \text { inhabitants (\% of } \\
\text { population in 2000) }\end{array}$ & 119 & 0.408 & $<0.001$ \\
\hline $\begin{array}{l}\text { Urban and Rural Areas: Growth } \\
\text { rate of rural population (\%) }\end{array}$ & 142 & (0.337) & $<0.001$ \\
\hline
\end{tabular}




\section{Conclusions}

The review and analysis presented in Chapter 2 found that most of the usual measuring approaches used to assess global sustainable development overlook human consumption patterns in relation to the planet's carrying capacity. As long as these measures continue to receive credibility, development within the ecological limits imposed by the planet's carrying capacity is unlikely to become a priority for policy makers.

The Global Sustainability Quadrant approach offers a new standard for assessing sustainable development, one that is more in tune with the physical requirements of sustainability. The top ranking countries according to this approach are not the ones that usually top the "Most Developed" lists published in the literature, so it is expected that some will find all this difficult to digest.

The analysis of metrics that was based on the Quadrant approach yielded results that could serve as solid stepping stones for developing better indicators and indices, and perhaps aid policy-makers and other researchers in future endeavors. However, as with any analysis that deals with such (unimaginably) complex matters as global sustainable development, a great degree of caution is required when interpreting the meaning of such results. Without further research, it would be unwise to make concrete statements about a given metric's influence on a given country - surely in many instances, their benefits to sustainability will be less than marginal, or even counterproductive.

Ultimately, the value a reader might assign to this work depends mainly on whether s/he considers the Ecological Footprint and the Human Development Index as valid and reliable measurements or not.

With this in mind, the following general conclusions can be inferred from the analysis:

Access to information, research, and technology: Society tends to place great hopes in new technologies to reduce the environmental impact of human activities. Sustainability-related issues also seem to be gaining exposure in the media, and there is no doubt that the power of the internet and modern telecommunications plays a major role in this. Nevertheless, many metrics that pertain to these issues (e.g., cellular phone use, telephone mainlines, homes with internet connections, number of researchers per thousand persons, recovered paper for recycling, renewable energies, etc .), show negative correlations (or no correlation, in the case of renewables) with proximity and/or movement to the Quadrant.

All this could mean that the societal benefits of increased information, research, and technology - which are also associated with affluence - are being overshadowed by increased consumption of resources. Or perhaps it could be explained by the idea that the need to recycle, use renewable energy, conduct research, etc., arises when the effects of un-sustainability start to be felt. 
Another possible explanation for this can be related to the Jevons Paradox: "In 1865, the English economist William Stanley Jevons wrote a book called The Coal Question. In it, he observed that the consumption of coal had gone up in England even after more efficient technologies, like an improved steam engine, had been introduced." (Rocky Mountain Institute, 2008). Thus, the Jevons Paradox is used to describe what happens when technological advances that increase resource-use efficiency actually increase the rate at which that resource is consumed.

Biodiversity and forest cover: Overall, the relationship between sustainable development and biodiversity/forest cover appears to indicate that countries who are deforesting are achieving 'development' at the expense of the natural capital, but after a while the negative effects of such losses start to be felt.

Carbon footprint: As the carbon footprint increases its share in a country's total ecological footprint, the country tends to move away from the Quadrant. Nevertheless, countries with a high share of carbon footprint tend to be closer to the Quadrant in the present-day (although this correlation is less significant than the ones observed historically). The relationship between sustainable development and carbon emissions also appears to be analogous to the one that exists with debt: intensive use of carbon emitting technologies has put come countries in a 'good' position, but eventually, as the carbon footprint increases it becomes a burden. This could also be associated with a particular moment in a nation's path towards development (see Environmental Kuznet's Curve hypothesis). ${ }^{32}$

Components of the Human Development Index: As GDP Per capita increases, a country tends to move away from the Quadrant. This should be related to an increased consumption of resources brought upon by the population's growing purchasing power. Nevertheless, the other two components of the HDI (health and knowledge), show the opposite type of correlation - as they increase, countries tend to move towards the Quadrant. What makes all this more interesting is that these three components are strongly correlated between themselves - they tend to go hand in hand - so we must conclude that the analysis was able to isolate the impact of GDP. This also tells us that growth of health and knowledge are not necessarily conditioned by growth of income.

Contraception: Countries where contraception methods are more widespread tend to be closer to the Quadrant. It is very interesting to note that, even though the Distance From the Quadrant is determined by per capita figures - population growth rate is not factored in contraception still shows up with a significant association to a country's sustainable development.

Debt: As its debt grows in time, a country tends to move away from the Quadrant. A debt-free country should be better positioned to achieve sustainable development. Nevertheless, countries with higher debts tend to be closer to the Quadrant in the present-day; perhaps this explains how they got there. The trend seems to make perfect sense: borrowing money can solve problems today, but eventually can turn into a burden.

\footnotetext{
${ }^{32}$ See footnote 25 .
} 
Development aid: Countries that receive more official development assistance, as well as those who have a larger number of International NGOs, tend to be farther away from the Quadrant. This could indicate that development initiatives are being directed to where they are needed the most, or that they are ultimately ineffective in fostering sustainable development.

Diversity: Ethnic diversity does not seem to be a factor that influences proximity to the Sustainability Quadrant. However, it does appear that having many different religions, and even more so, many different languages spoken within a country, has a negative impact - countries with high language and religious diversity tend to be farther away from the Quadrant.

Energy: The fact total energy consumption shows negative correlation with proximity and/or movement to the Quadrant, but most of the individual sources analyzed (including renewables) do not, may indicate that reducing overall consumption has more incidence on sustainable development than finding cleaner sources.

Population dynamics: The results of the analysis of metrics that pertain to human population dynamics are somewhat puzzling:

- As fertility rate increases within a country, it tends to move away from the Quadrant. This may indicate increased pressure on resources, associated with overpopulation, which may lead to their unsustainable use. The fact that this metric shows correlation only in the last few years (but not in the long and medium terms) may indicate that humanity is at the point in history where population has finally surpassed the planet's carrying capacity.

- Nevertheless, as population density increases, the country tends to move towards the Quadrant. A possible explanation could lie in the population-imposed constraints on the available resources, which can force their more efficient use (e.g., in cities).

- Mortality rates are clearly associated with movement away from the Quadrant.

- Net emigration is correlated with movement towards the Quadrant, as well as with present-day proximity to it, which contradicts the idea that countries that advancing sustainable development would attract people, not drive them away.

A more in depth analysis of these correlations is needed before any reliable interpretation can be made.

Governance and policies: The impacts of good governance and good policies are difficult to quantify and measure. That is why few governance/policy-related metrics could be included in the analysis. Nevertheless, their importance should not be overlooked; good governance and good policies are society's tools to drive the economy towards sustainable development.

Meat consumption: As a country's meat consumption per capita and its nutritional supply derived from animal products increase in time, it tends to move away from the Quadrant. This seems to indicate that the environmental impacts associated with meat production (mainly deforestation in the 'developing' world, and industrial pollution in the 'developed' world) have 
more incidence on overall sustainability than the nutritional gains (protein content) provided by it.

Urbanization: A trend that shows positive correlation with sustainability, which may not be so obvious at first glance, is the growth of urban population in relation to rural population. It is widely known that the global human population is moving to the city. Rather than viewing cities as the large clusters of consumption and pollution that they sometimes are, they could be viewed as blessings in disguise. The reason is this: the concentration of human populations within a city offers unique opportunities to manage resources and control wastes more efficiently on a per capita basis; plus, it will leave room for nature to thrive with less human 'interference.' Even though there are many uncertainties surrounding the human condition in the years to come, there is little doubt that the future of humankind lies in the city. 


\section{Possibilities for Further Research ${ }^{33}$}

As indicated in the previous chapters, the interpretations of the results of the analysis, although based on the correlation coefficients found, are merely speculative. The next logical question to address is: why is this happening? A look at the Conclusions (Chapter 6) could provide starting points for more in-depth studies.

Some approaches to further research include:

- Conducting a separate analysis of those countries that have an HDI below 0.8 , and those that have one above 0.8 . The latter part is particularly interesting because countries with high HDI that are also reducing their EF are going against the flow, and therein lies the key to achieving sustainability.

- Categorization of the results: Several indicator categorization frameworks exist that may help to better sort out the identified metrics. Jeon, et al., 2005, identifies four distinct types of framework:

Linkages-based: These frameworks explore the relationship between causes, impacts, and actions associated with sustainability. The popular Driving forcePressure-State-Impact-Response (DPSIR) ${ }^{34}$ approach is an example of this type of framework, where indicators are placed within one of these five categories. For example, a driving force (e.g., growth of urban population) creates pressure (more cars that bring increased $\mathrm{NO}_{2}$ emissions), which changes the state of the system (increased $\mathrm{NO}_{2}$ concentration in the city), which in turn has an impact (higher incidence of respiratory illness) that originates a response (creation of carpool lanes) from the government.

Impacts-based: They classify indicators according to the type of impact they generate (e.g., economic, environmental, or social), without focusing on their causes or corrective measures.

Influence-oriented: This type of framework is institution-centered. It is "developed bearing in mind the relative levels of influence that the responsible agency or organization has on various actions and/or activities that influence progress toward sustainability" (Jeon, et al., 2005).

Process-based: They rely on a predefined vision and monitor actions taken to fulfill that vision.

- Both the HDI and EF dimensions were given equal weight in the calculation of distance/movement relative to the Quadrant. In reality, it is unlikely that both would have the same degree of incidence on overall sustainable development. To combine both dimensions more accurately, we would need to answer this question: Is it easier to

\footnotetext{
${ }^{33}$ For access to the vast wealth of data compiled for this study, contact the author: abtarte@mtu.edu.

${ }^{34}$ The DPSIR model is an extension of the PSR (Pressure-State-Response) model, developed by Anthony Friend in the 1970s, and subsequently adopted by the OECD's State of the Environment (SOE) group.
} 
improve health, knowledge, and standard of living for the world's population, or to lower its consumption patterns?

- Conducting a more thorough statistical analysis of the data (perhaps using non-linear analysis tools) could identify the relationships that are truly meaningful, as well as better describe their behavior, including when their benefits to sustainability start to become marginal. This includes determining if a specific metric identified in this analysis correlates with simultaneous progress on both dimensions (EF and HDI), or if it correlates with only on one of them, so strongly, that it overshadows the other.

- Regional analyses of the data could determine if the correlations apply only to particular parts of the world. 


\section{References}

Adams, W.M. 2006. The Future of Sustainability: Re-thinking Environment and Development in the Twenty-first Century. Report of the IUCN Renowned Thinkers Meeting, 29-31 January, 2006.

Alesina, Alberto, et al. "Fractionalization," Journal of Economic Growth, Springer, vol. 8(2), pages 155-94, June, 2003.

Bea-Taylor, Jonah. Beating the Energy Efficiency Paradox. Rocky Mountain Institute website. http://www.rmi.org/sitepages/pid481.php. (Accessed 08/01/09).

Bossert, Walter, Conchita D'Ambrosio, and Eliana Laferrara. 2006. A Generalized Index of Fractionalization, Working Papers 313, IGIER (Innocenzo Gasparini Institute for Economic Research), Bocconi University, Italy.

Boutaud A. 2002. "Développement durable: quelques vérités embarrassantes," Economie et Humanisme 363: 4-6.

Cohen, J. 1988. Statistical power analysis for the behavioral sciences (2nd ed.). New Jersey: Lawrence Erlbaum Associates, Inc.

Dasgupta, Susmita, Benoit Laplante, Hua Wang, and David Wheeler. "Confronting the Environmental Kuznets Curve," The Journal of Economic Perspectives, Vol. 16, No. 1. (Winter, 2002), pp. 147-168.

Del Siegle, Ph.D. website: accessed May 2009

http://www.gifted.uconn.edu/Siegle/research/Correlation/alphaleve.htm

Department of Economic and Social Affairs of the United Nations Secretariat. Indicators of Sustainable Development: Guidelines and Methodologies. October 2007, third edition. United Nations: New York, 2007.

Diamond, Jared. 2005. Collapse: How Societies choose to Fail or Succeed. Penguin Books, New York.

DIVA-GIS, Thematic Mapping. World Countries Boundary File, World, 2002. Licensed under a Creative Commons Attribution 3.0 License.

http://finder.geocommons.com/overlays/5603

Environmental Vulnerability Index website. The EVI in Summary.

http://www.vulnerabilityindex.net/. (Accessed April 2009).

Esty, Daniel C., Marc Levy, Tanja Srebotnjak, and Alexander de Sherbinin. 2005 Environmental Sustainability Index: Benchmarking National Environmental Stewardship. New Haven: Yale Center for Environmental Law \& Policy. 
Ewing B., A. Reed, S.M. Rizk, A. Galli, M. Wackernagel, and J. Kitzes. 2008. Calculation Methodology for the National Footprint Accounts, 2008 Edition. Oakland: Global Footprint Network.

Ewing B., S. Goldfinger, M. Wackernagel, M. Stechbart, S. M. Rizk, A. Reed and J. Kitzes. 2008. The Ecological Footprint Atlas 2008. Oakland: Global Footprint Network.

Frey, Hildebrand and Paul Yaneske. Visions of Sustainability. 2007. Taylor \& Francis, London and New York.

Galbraith, James K. and Hyunsub Kum. 2004. Estimating the Inequality of Household Incomes: A Statistical Approach to the Creation of a Dense and Consistent Global Data Set. UTIP Working Paper No. 22 (revised version V). LBJ School of Public Affairs, The University of Texas at Austin.

Global Footprint Network. 2008. National Footprint Accounts, 2008 edition. Available online at: www.footprintnetwork.org.

Global Footprint Network. 2009. Africa: Ecological Footprint Factbook 2009, version 1.0. Http://Www.Footprintnetwork.Org/Images/Uploads/Africafactbook_2009.Pdf

Global Footprint Network website. Ecological Footprint Methodology Overview http://www.footprintnetwork.org/en/index.php/GFN/page/methodology/ (Accessed April, 2009).

Hardin, Garrett, "The Tragedy of the Commons," Science, Vol. 162, No. 3859 (December 13, 1968): 1243-1248.

Hawken, Paul, Amory Lovins, and L. Hunter Lovins. 1999. Natural Capitalism: Creating the Next Industrial Revolution. Little, Brown and Company, Boston.

Hermele, Kenneth. Greening the Human Development Index DRAFT. Paper presented to the Workshop on Trade and Environmental Justice, Lund University, 15-16 February, 2006.

Hoekstra, A.Y. and Chapagain, A.K. 2008. Globalization of water: Sharing the planet's freshwater resources. Blackwell Publishing, Oxford, UK.

Jeon, Christy Mihyeon and Adjo Amekudzi. "Addressing Sustainability in Transportation Systems: Definitions, Indicators, and Metrics," Journal of Infrastructure Systems, Vol. 11, No. 1, March 1, 2005.

Jesinghaus, Jochen. Indicators for Decision-Making. European Commission, JRC/ISIS, TP 361, I21020 Ispra (VA). Draft of 12.12.1999. 
Kates, Robert W., Thomas M. Parris, and Anthony A. Leiserowitz. "What is Sustainable Development? Goals, Indicators, Values, and Practice," Environment: Science and Policy for Sustainable Development, Volume 47, Number 3, pages 8-21., 2005.

Marcs, Nic, Saamah Abdallah, Andrew Simms, and Sam Thompson. The Unhappy Planet Index. The New Economics Foundation, 2006.

http://www.neweconomics.org/gen/uploads/dl44k145g5scuy453044gqbu11072006194758.pdf

McDonach, K. and Yaneske, P. P. 2002, 'Environmental Management Systems and Sustainable Development'. The Environmentalist, 22: 217-226.

Mobilgistix Ltd. 2009. Average Latitude \& Longitude of Countries, available at http://www.mobilgistix.com/Resources/GIS/Locations/average-latitude-longitudecountries.aspx.

New Economics Foundation. The Happy Planet Index. http://www.happyplanetindex.org/about.htm (Accessed April 2009).

Nováček, Pavel and Peter Mederly. Global Partnership for Development. American Council for United Nations University, May 2002.

Pintér, László, Peter Hardi and Peter Bartelmus. Indicators of Sustainable Development: Proposals for a Way Forward. International Institute for Sustainable Development, December 2005.

Prescott-Allen, Robert. The Structure of a Wellbeing Index: Evaluation of the Proposed Structure of the Wellbeing Index. Developed for debate at the JRC/OECD workshop, June 2006, Milano.

Redefining Progress website. Genuine Progress Indicator.

http://www.rprogress.org/sustainability_indicators/genuine_progress_indicator.htm. (Accessed April 2009).

Reed, Anders. Research Associate, Global Footprint Network. Personal communication, May $21^{\text {st }}, 2009$.

Simon, Julian L. 1996. The Ultimate Resource II. Princeton University Press, Princeton, New Jersey.

Socioeconomic Data and Applications Center (SEDAC), Center for International Earth Science Information Network (CIESIN), Columbia University. 2007. SEDAC Compendium of Environmental Sustainability Indicator Collections. Version 1.1 - Data Dictionary. Trustees of Columbia University in the City of New York.

Sustainable Society Index (SSI) website. Description of the Sustainable Society Index (SSI). http://www.sustainablesocietyindex.com/ssi-description.htm. (Accessed April 2009). 
Swiss Agency for Development and Cooperation \& Global Footprint Network. Africa's Ecological Footprint: Human Wellbeing and Ecological Capital - 2006 Factbook. Global Footprint Network, 2006.

Tarté, Rodrigo. 2006. Picnic con Hormigas: Reflexiones sobre Gestión del Conocimiento y Desarrollo (Sostenible). Ciudad del Saber, Panama.

The Economist Intelligence Unit. 2005. Quality-of-life index. The world in 2005. http://www.economist.com/media/pdf/QUALITY_OF_LIFE.PDF

UNDP, UNEP, World Bank, and World Resources Institute. 2000. World Resources 2000-2001: People and ecosystems: The fraying web of life. World Resources Institute, Washington, D.C.

United Nations Development Programme (UNDP). 2008. Human Development Reports, 2008. http://hdr.undp.org.

United Nations Development Programme (UNDP). 2008. Human Development Report 2007/2008 - TECHNICAL NOTE 1: Calculating the human development indices. http://origin-hdr.undp.org/en/media/HDR_20072008_Tech_Note_1.pdf

United Nations Development Programme (UNDP). What Is the Human Development Index (HDI)? Human Development Reports website:

http://hdr.undp.org/en/statistics/indices/hdi/question,68,en.html . (Accessed August 2009).

United Nations. 2002. Global Challenge. Global Opportunity. Trends In Sustainable Development. United Nations Department of Economic and Social Affairs, New York.

Veenhoven, R. Average happiness in 145 nations 2000-2008, World Database of Happiness, Rank Report 2009-1a. http:// worlddatabaseofhappiness.eur.nl

Vintar Mally, Katja. "Linking Socio-Economic Development And Environmental Pressures", Razprave, Vol. 27, 2007, pp. 149-162. Slovenia.

http://www.ff.uni-lj.si/oddelki/geo/publikacije/dela/files/Dela_27/08_vintar.pdf

Wilson, Jeffrey, Peter Tyedmers and Ronald Pelot. "Contrasting and comparing sustainable development indicator metrics," Ecological Indicators 7 (2007) 299-314.

World Commission on Environment and Development, 1987. Our Common Future, Report of the World Commission on Environment and Development, Published as Annex to General Assembly document A/42/427, Development and International Co-operation: Environment August 2, 1987.

World Resources Institute. 2009. Earth Trends: Environmental Information web portal. http://earthtrends.wri.org/ 
Worldwatch Institute. 2008. Vital Signs 2007-2008. Worldwatch Institute, Washington, DC. http://www.worldwatch.org/vs2007

World Wildlife Fund and Global Footprint Network. 2008. Africa: Ecological Footprint and Human Wellbeing. http://www.footprintnetwork.org/download.php?id=502 


\section{Appendix A: Overview of Composite Sustainability Indicator Frameworks Reviewed}

\section{The Ecological Footprint}

Developed by: William Rees and Mathis Wackernagel, refined and presently carried forward by the Global Footprint Network.

http://www.footprintnetwork.org

The Ecological Footprint puts human consumption in terms of the amount of 'biologically productive land and sea area' required to produce what we consume and assimilate what we discard. "The area of land or sea available to serve a particular use is called biocapacity, and represents the biosphere's ability to meet human demand for material consumption and waste disposal. The Ecological Footprint and biocapacity accounts cover six land use types: cropland, grazing land, fishing ground, forest land, built-up land and carbon uptake land (to accommodate the Carbon Footprint). For each component, the demand for ecological services is divided by the yield for those ecological services to arrive at the Footprint of each land use type. Ecological Footprint and biocapacity are scaled with yield factors and equivalence factors to convert this physical land demanded to world average biologically productive land called global hectares. This allows for comparisons between various land use types with differing productivities (Ewing, et al., 2008).

The following information has been copied from: Global Footprint Network website. Ecological Footprint Methodology Overview http://www.footprintnetwork.org/en/index.php/GFN/page/methodology/ (accessed April, 2009).

Global Footprint Network's core research calculates both the Ecological Footprint, the demand on nature, and biocapacity, the capacity to meet this demand, of more than 200 countries. The results, updated annually, as well as the calculations are shown in the National Footprint Accounts. The 2008 National Footprint Accounts use over 5,400 data points for each country, each year, derived from internationally recognized sources to determine the area required to produce the biological resources a country uses and to absorb its wastes, and to compare this with the area available. This area is reported in global hectares (global acres), hectares (acres) with world-average productivity, for each year from 1961 through $2005 \ldots$

The Ecological Footprint uses yields of primary products (from cropland, forest, grazing land and fisheries) to calculate the area necessary to support a given activity. Biocapacity is measured by calculating the amount of biologically productive land and sea area available to provide the resources a population consumes and to absorb its wastes, given current technology and management practices. Countries differ in the productivity of their ecosystems, and this is reflected in the accounts.

A nation's consumption is calculated by adding imports to and subtracting exports from its national production. Results from this analysis shed light on a country's ecological impact. For example, the National Footprint Accounts identify whether or not a country's Ecological Footprint exceeds its biocapacity. A country has an ecological reserve if its Footprint is smaller than its biocapacity; otherwise it is operating with an ecological deficit. The former are often 
referred to as ecological creditors, and the latter ecological debtors. Today, most countries, and the world as a whole, are running ecological deficits. The world's ecological deficit is referred to as global ecological overshoot."

The following information has been copied from: Ewing B., A. Reed, S.M. Rizk, A. Galli, M. Wackernagel, and J. Kitzes. 2008. Calculation Methodology for the National Footprint Accounts, 2008 Edition. Oakland: Global Footprint Network.

Ecological Footprint accounting is based on six fundamental assumptions (Wackernagel et al. 2002):

- The majority of the resources people consume and the wastes they generate can be tracked.

- Most of these resource and waste flows can be measured in terms of the biologically productive area necessary to maintain flows. Resource and waste flows that cannot be measured are excluded from the assessment, leading to a systematic underestimate of humanity's true Ecological Footprint.

- By weighting each area in proportion to its bioproductivity, different types of areas can be converted into the common unit of global hectares, hectares with world average bioproductivity.

- Because a single global hectare represents a single use, and all global hectares in any single year represent the same amount of bioproductivity, they can be added up to obtain an aggregate indicator of Ecological Footprint or biocapacity.

- Human demand, expressed as the Ecological Footprint, can be directly compared to nature's supply, biocapacity, when both are expressed in global hectares.

- Area demanded can exceed area supplied if demand on an ecosystem exceeds that ecosystems regenerative capacity (e.g., humans can temporarily demand more biocapacity from forests, or fisheries, than those ecosystems have available). This situation, where Ecological Footprint exceeds available biocapacity, is known as overshoot...

Limitations of the Ecological Fooptrint method

The Ecological Footprint is designed to answer a specific research question: How much of the biosphere's regenerative capacity is occupied by human activities? The method is limited in three ways: Some aspects of sustainability are excluded from its scope; some aspects of demand are hard to quantify; and like any method, errors can occur in the implementation. The Ecological Footprint Standards require that Footprint studies specify the limitations of the assessment. In particular, the Standards emphasize that the Footprint is not a complete indicator of sustainability, and needs to be complemented by other measures.

What the Footprint Does Not Measure

Non-ecological aspects of sustainability. The Footprint is, by design, not a complete sustainability measure. A single metric that includes all aspects of sustainability, even if possible, would produce results that would have little utilitarian value. Having a Footprint smaller than global biocapacity is a necessary minimum condition for humanity's sustainability, but is not sufficient. For instance, social well-being also needs to be tracked, but this is not measured by the Footprint. The Ecological Footprint also makes no attempt to evaluate the long-term viability of social structures, economies, or political systems. Neither does it identify the drivers - it simply 
documents one particular ecological outcome: the demand on nature resulting from human activities that occurred at a given time.

-Depletion of non-renewable resources. The Footprint does not track the amount or the depletion of non-renewable resource stocks, such as oil, natural gas, coal or metal deposits. It focuses on regenerative capacity as the limiting factor, and captures the use of fossil fuels and minerals in as far as this makes a demand on the biosphere's regenerative capacity.

-Inherently unsustainable activities. Activities that are inherently unsustainable, such as the release of heavy metals, radioactive materials and persistent synthetic compounds (chlordane, PCBs, CFCs, PVCs, dioxins, etc.), do not enter into Footprint calculations. Nature does not have any significant capacity to break down and process these compounds, so the recycling of these materials cannot be the biosphere cannot assimilate any of these materials within human timescales, integration of these factors into Footprint calculations would result in infinitely large, and therefore meaningless, values.

-Ecological degradation. The Footprint does not directly measure ecological degradation, such as increased soil salinity from irrigation that could affect future productivity. However, if degradation leads to reductions in biological productivity, this loss is captured in future biocapacity accounts. The Footprint is not predictive in this sense, but documents effects as they occur. This avoids making Footprint assessments speculative.

-Resilience of ecosystems. Ecosystems have the capacity to tolerate some disturbance without collapsing. Excessive disturbance, leading to collapse, does not mean extermination of life, but rather a shift of the ecosystem into a qualitatively different state, with a new species composition.

What the Footprint does not measure well

-Waste flows. For many waste flows, inadequate data sets exist for Footprint calculations. For example, SOx emissions from fossil fuel-based power plants contribute to the acidification of rainwater, which has detrimental effects on forests, fish and wildlife. However, at this time, globally comparable data on the relationship between SOx concentration and biocapacity are lacking. Acid rain does not yet enter into Footprint calculations, but may in the future if better data become available.

-Freshwater use. Freshwater use is only indirectly included in the Footprint due to lack of data that link freshwater use with loss in bioproductivity. Some local Footprint assessments have included freshwater use, but national assessments do not yet do so. Freshwater shortages that do result in declining bioproductivity are reflected in biocapacity measurements. Making Ecological Footprint assessments more relevant to freshwater issues is a research task.

-Nuclear power. The challenges with nuclear power are poorly captured with the Ecological Footprint, and hence the Footprint is ill-suited to analyze the utility or risk of nuclear power. When analyzing nuclear power one needs to consider wider issues, such as costs, nuclear waste, military proliferation, and operational risks. The 2008 Edition no longer includes nuclear energy at par with fossil fuel.

-Aspects of demand for which data are sparse. Most of the underlying data sets used to calculate national Footprints and biocapacities come from the United Nations, namely from the UN Food 
and Agriculture Organization (UN FAO). These data sets do not include assessments of the uncertainty or reliability of included data. Accordingly, Footprint results must be interpreted with the provison that they assume the underlying data is correct. When there is doubt about data values, Footprint calculations generally exclude or use lower estimates for demand on nature, and use optimistic biocapacity accounts. This is done to avoid exaggerating ecological deficits. Results, therefore, most likely underestimate the extent of humanity's ecological overshoot.

The following information has been copied from : Anders Reed, Research Associate, Global Footprint Network, personal communication:

[An observation about the $\mathrm{EF}^{\prime} \mathrm{s}$ ] incomplete source data, or reporting errors: our major datasets such as FAO, do not necessarily have data for all countries. Where data is missing, we try to still provide the best estimate we can based on what is available.

[An observation about the EF's] trade assumptions: we assume that all imported and exported goods have world average footprint intensities [global hectares/tonne]. This assumption is sufficient in many cases, but leads to unlikely results where a country's actual production intensities differ substantially from the world average. Trade modeling is currently at the forefront of our research agenda, so look for significant improvements in this area within the next few years.

\section{Human Development Index (HDI)}

Developed by: United Nations Development Programme (UNDP). http://hdr.undp.org

\section{The following information has been copied from the Human Development Reports website:}

The first Human Development Report (1990) introduced a new way of measuring development by combining indicators of life expectancy, educational attainment and income into a composite human development index, the HDI. The breakthrough for the HDI was the creation of a single statistic which was to serve as a frame of reference for both social and economic development. The HDI sets a minimum and a maximum for each dimension, called goalposts, and then shows where each country stands in relation to these goalposts, expressed as a value between 0 and $1 \ldots$

The HDI - human development index - is a summary composite index that measures a country's average achievements in three basic aspects of human development: health, knowledge, and a decent standard of living. Health is measured by life expectancy at birth; knowledge is measured by a combination of the adult literacy rate and the combined primary, secondary, and tertiary gross enrolment ratio; and standard of living by GDP per capita (PPP US\$).

The following dimensions and weighting factors are used to calculate the HDI: 
Table A-1: Components of the HDI

Source: Adapted from UNDP, 2008.

\begin{tabular}{|c|c|}
\hline \multicolumn{1}{|c|}{ Dimension } & weight \\
\hline Life Expectancy Index & $\mathbf{1 / 3}$ \\
\hline Education Index & $\mathbf{1 / 3}$ \\
\hline Adult Literacy Rate & $2 / 3$ \\
\hline Combined Gross Enrollment Ratio & $1 / 3$ \\
\hline GDP Index & $\mathbf{1 / 3}$ \\
\hline
\end{tabular}

\section{Environmental Performance Index (EPI)}

Developed by: Yale Center for Environmental law and Policy, Yale University. http://www.yale.edu/envirocenter

The following information has been copied from: 2005 Environmental Sustainability Index Benchmarking National Environmental Stewardship, available at:

http://www.yale.edu/esi/f comparing.pdf:

The Environmental Sustainability Index was developed to evaluate environmental sustainability relative to the paths of other countries. Due to a shift in focus by the teams developing the ESI, a new index was developed, the Environmental Performance Index (EPI), that uses outcomeoriented indicators, then working as a benchmark index that can be more easily used by policy makers, environmental scientists, advocates and the general public.

The following diagram describes the components and weighting factors used in the calculation of the EPI: 
Figure A-1: Components and Weighting Factors of the EPI

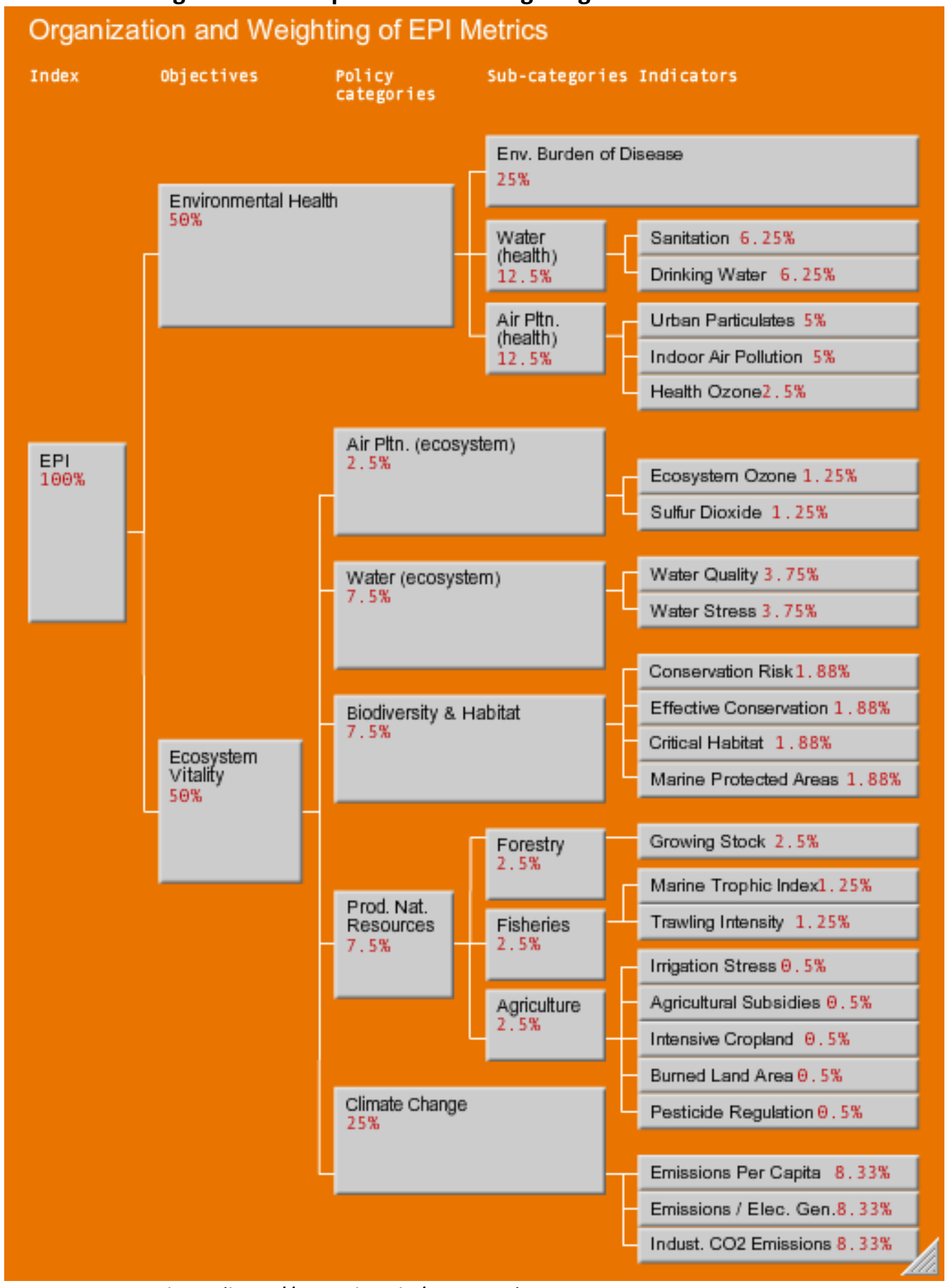

Source: EPI website (http://epi.yale.edu/Contents) 


\section{Environmental Sustainability Index (ESI)}

Developed by: Yale Center for Environmental Law and Policy (YCELP) and the Center for International Earth Science Information Network (CIESIN) of Columbia University, in collaboration with the World Economic Forum and the Joint Research Centre of the European Commission. http://sedac.ciesin.columbia.edu/es/esi/

The following information has been copied from: Esty, Daniel C., Marc Levy, Tanja Srebotnjak, and Alexander de Sherbinin (2005). 2005 Environmental Sustainability Index: Benchmarking National Environmental Stewardship. New Haven: Yale Center for Environmental Law \& Policy:

The Environmental Sustainability Index (ESI) benchmarks the ability of nations to protect the environment over the next several decades. It does so by integrating 76 data sets - tracking natural resource endowments, past and present pollution levels, environmental management efforts, and the capacity of a society to improve its environmental performance - into 21 indicators of environmental sustainability.

These indicators permit comparison across a range of issues that fall into the following five broad categories:

- Environmental Systems

- Reducing Environmental Stresses

- Reducing Human Vulnerability to Environmental Stresses

- Societal and Institutional Capacity to Respond to Environmental Challenges

- Global Stewardship

The indicators and variables on which they are constructed build on the well-established 'Pressure-State-Response' environmental policy model. The issues incorporated and variables used were chosen through an extensive review of the environmental literature, assessment of available data, rigorous analysis, and broad-based consultation with policymakers, scientists, and indicator experts.

While they do not provide a definitive vision of sustainability, the collection of indicators and variables that form the 2005 ESI provide: (1) a powerful tool for putting environmental decisionmaking on firmer analytical footing (2) an alternative to GDP and the Human Development Index for gauging country progress, and (3) a useful mechanism for benchmarking environmental performance.

The following table lists the five broad categories and the 22 sub-categories that compose the ESI: 
Table A-2: Components of the ESI

Source: Adapted from Esty, et al., 2005.

\begin{tabular}{|c|c|}
\hline \multicolumn{2}{|r|}{ Environmental Sustainability Index (ESI) } \\
\hline \multirow[t]{5}{*}{ Environmental Systems } & $\begin{array}{l}\text { Water quantity, including measures of the availability of } \\
\text { surface freshwater as well as groundwater. }\end{array}$ \\
\hline & $\begin{array}{l}\text { Water quality, including measures of eutrophication, } \\
\text { turbidity, dissolved oxygen, and other critical indicators. }\end{array}$ \\
\hline & $\begin{array}{l}\text { Air quality, including measures of pollutants such as sulfur } \\
\text { dioxide, nitrogen oxides, particulates, volatile organic } \\
\text { compounds (VOCs), and ozone. }\end{array}$ \\
\hline & $\begin{array}{l}\text { Landscape, including measures of urbanization, } \\
\text { deforestation, agricultural conversion, and other } \\
\text { anthropogenic alterations of the land. }\end{array}$ \\
\hline & $\begin{array}{l}\text { Biodiversity, including measures of both genetic and } \\
\text { organismic diversity as well as of preservation of critical } \\
\text { habitat and fragmentation of ecosystems. }\end{array}$ \\
\hline \multirow[t]{6}{*}{$\begin{array}{l}\text { Reducing Environmental } \\
\text { Stresses }\end{array}$} & $\begin{array}{l}\text { Air pollution emissions, including emissions of the criteria air } \\
\text { pollutants sulfur dioxide, nitrogen oxides, and volatile organic } \\
\text { compounds (VOC). }\end{array}$ \\
\hline & Water pollution and consumption. \\
\hline & $\begin{array}{l}\text { Stresses on ecosystem functioning, including measures of } \\
\text { anthropogenic disturbances to aquatic, terrestrial, and } \\
\text { marine ecosystems. }\end{array}$ \\
\hline & $\begin{array}{l}\text { Waste and consumption, including measures of solid waste } \\
\text { generation, landfill volume, hazardous waste generation, } \\
\text { unsafe disposal of waste, and natural resource consumption } \\
\text { relative to carrying capacities. }\end{array}$ \\
\hline & Natural Resource management. \\
\hline & Population, including measures of fertility and total growth. \\
\hline \multirow{3}{*}{$\begin{array}{l}\text { Reducing Human } \\
\text { Vulnerability to } \\
\text { Environmental Stresses }\end{array}$} & Basic human substenance. \\
\hline & $\begin{array}{l}\text { Environmental health, including measures of morbidity and } \\
\text { mortality stemming from waterborne vectors, such as } \\
\text { intestinal infectious diseases; from poor air quality, such as } \\
\text { respiratory diseases; and from exposure to toxins and } \\
\text { mutagens, such as some cancers. }\end{array}$ \\
\hline & $\begin{array}{l}\text { Susceptibility to environmentally-related natural disasters, } \\
\text { such as floods, droughts, landslides and hurricanes. }\end{array}$ \\
\hline
\end{tabular}


Table A-2 (continued)

\begin{tabular}{|l|l|}
\hline \multicolumn{2}{|c|}{ Environmental Sustainability Index (ESI) } \\
\hline $\begin{array}{l}\text { Societal and Institutional } \\
\text { Environmental Challenges }\end{array}$ & $\begin{array}{l}\text { Environmental governance, including measures of the } \\
\text { effectiveness of the environmental regulatory apparatus, the } \\
\text { flexibility and innovativeness of the regulatory regime, the } \\
\text { strictness of enforcement of environmental laws as well as } \\
\text { the extent of endemic problems such as corruption or } \\
\text { deviation from rule of law, the use of best practices } \\
\text { concerning monitoring, assessment, and implementation, the } \\
\text { extent of public participation in environmental } \\
\text { decisionmaking, and the availability of environmental } \\
\text { information. }\end{array}$ \\
\cline { 2 - 2 } & $\begin{array}{l}\text { Science and Technology, including measures of the level of } \\
\text { environmental knowledge among the public, the capacity of a } \\
\text { society to respond to technical challenges, and the ability of a } \\
\text { society to innovate and generate less environmentally } \\
\text { harmful products and production processes over time. }\end{array}$ \\
\cline { 2 - 3 } & $\begin{array}{l}\text { Private Sector Responsiveness to Environmental Challenges, } \\
\text { including measures of private sector compliance with laws, } \\
\text { commitment to environmental stewardship, and capacity for } \\
\text { environment-related innovation. }\end{array}$ \\
\hline & Eco-Efficiency. \\
\hline Global Stewardship & Greenhouse Gas Emissions. \\
\hline & Participation in international collaboration. \\
\hline & Transboundary environmental pressures. \\
\hline
\end{tabular}

\section{Sustainable Society Index (SSI)}

Developed by: Sustainable Society Foundation - SSF

http://www.sustainablesocietyindex.com/home.htm

The following information has been copied from: http://www.sustainablesocietyindex.com/ssidescription.htm:

Over the years many indexes have been developed, among which some very good ones. However, until recently there was no index which:

- comprises all aspects of a sustainable society,

- is simple, clear and transparent,

- is adequate for a comparison between countries,

- and is regularly updated. 
For this reason, a new index - the Sustainable Society Index (SSI) - has been developed by the Sustainable Society Foundation. The newly developed Sustainable Society Index, the SSI, integrates for the first time sustainability and quality of life in an understandable way. The SSI is based on public data from scientific research institutes and international organizations.

A detailed description can be read in 'A comprehensive index for a sustainable society: The SSI - the Sustainable Society Index,' published in Ecological Economics, Volume 66/2-3, pp 228-242.

The framework of the Index for a Sustainable Society consists of five categories, each built up from several indicators:

\author{
Personal Development [weight: $1 / 7]$ \\ Healthy Life \\ Sufficient Food \\ Sufficient to Drink \\ Safe Sanitation \\ Education Opportunities \\ Gender Equality \\ Healthy Environment [weight: 1/7] \\ Air Quality \\ Surface Water Quality \\ Land Quality \\ Well-balanced Society [weight: $1 / 7$ ] \\ Good Governance \\ Employment \\ Population Growth \\ Income Distribution \\ Public Debt \\ Sustainable Use of Resources [weight: 2/7] \\ Waste Recycling \\ Use of Renewable Water Resources \\ Consumption of Renewable Energy \\ Sustainable World [weight: $2 / 7$ ] \\ Forest Area \\ Preservation of Biodiversity \\ Emission of Greenhouse Gases \\ Ecological Footprint \\ International Cooperation"
}

\title{
Environmental Vulnerability Index (EVI)
}

Developed by: South Pacific Applied Geoscience Commission (SOPAC), the United Nations Environment Programme (UNEP) and their partners.

http://www.vulnerabilityindex.net

The following information has been copied from the EVI's website:

http://www.vulnerabilityindex.net/: 
Environmental Vulnerability - The Issue

Healthy, productive and protective environments, social systems and economies are the basis of sustainable development and human welfare. The environment is the source of all our raw materials and absorbs the pollution from our activities. In turn, whilst going about our daily business (social and economic) we use the environment and convert its resources and natural services into those that directly support us. The problem is that all of these systems can be damaged, overloaded, or prevented from meeting our needs. By our own choices we can to a large extent determine our own quality of life, the condition of our lands and opportunities for future generations.

Vulnerability is a new way of looking at an age-old problem. Instead of focusing just on what has been going wrong in the past and the effects of hazards, vulnerability gives us the opportunity to focus on getting things right for the future. As a future-focused approach, vulnerability is a way of using strengths and strategically improving weaknesses.

Vulnerability refers to the tendency of something to be damaged. The opposite of this is resilience, or the ability to resist and/or recover from damage. When we talk about vulnerability, we are automatically also talking about resilience because the two are opposite sides of a single coin. That is, something is vulnerable to the extent that it is not resilient, and visa versa.

The idea of vulnerability/resilience applies equally well to physical entities (people, ecosystems, coastlines) and to abstract concepts (social systems, economic systems, countries). The factors that cause the damage are known as hazards, each of which will be associated with some level of risk, or likelihood of occurring.

Why focus on vulnerability?

The vulnerability of our environmental, social and economic systems is made up of more than just the risk of disasters and good or bad management. It is not just about climate change, or globalisation, or trade agreements. It must also include an understanding of how well any system (environmental, social and economic) can cope with any hazards that may come its way and that might harm it. It would be impossible to work towards good quality of life and growth for countries under a sustainable development model if no account were made of the damage that can occur from internal and outside influences.

For development to be sustainable, we clearly need to learn to manage our vulnerabilities. We need to be able to understand and/or manage hazards, natural resilience and acquired resilience. This understanding for the first time opens up opportunities for improving our overall vulnerability because it forces us to examine the problem from all angles, instead of just focusing on the risk of disasters. Vulnerability management is emerging as a critical part of any sustainable development strategy.

The interesting thing about vulnerability is that it can be examined at different levels for different issues. That is, it can be used to look at a single issue, or to assess a complex entity such as a country... 
The underlying assumption is that the more degraded the ecosystems of a country (as a result of past natural and anthropogenic hazards), the more vulnerable it is likely to be to future hazards. Indicators were also selected to ensure a good spread of information across the different elements that comprise and/or affect ecosystems. Indicators on weather \& climate (6 indicators), geology (4), geography (6), ecosystem resources \& services (28) and human populations (6) were chosen to ensure a good cross-section of the ecological processes, including human interactions occurring in countries.

The EVI is calculated using a total of 50 indicators:

Table A-3: Components of the EVI

Source: Adapted from EVI website, 2009.

\begin{tabular}{|c|c|c|}
\hline \multicolumn{3}{|c|}{ Environmental Vulnerability Index } \\
\hline \multirow[t]{6}{*}{ Weather and Climate } & 1 & High Winds \\
\hline & 2 & Dry Periods \\
\hline & 3 & Wet Periods \\
\hline & 4 & Hot Periods \\
\hline & 5 & Cold Periods \\
\hline & 6 & Sea Temperature \\
\hline \multirow[t]{4}{*}{ Geology } & 7 & Volcanoes \\
\hline & 8 & Earthquakes \\
\hline & 9 & Tsunamis \\
\hline & 10 & Slides \\
\hline \multirow[t]{6}{*}{ Geography } & 11 & Land Area \\
\hline & 12 & Country Dispersion \\
\hline & 13 & Isolation \\
\hline & 14 & Relief \\
\hline & 15 & Lowlands \\
\hline & 16 & Borders \\
\hline \multirow[t]{12}{*}{ Resources and Services } & 17 & Ecosystem Imbalance \\
\hline & 18 & Environmental Openness \\
\hline & 19 & Migrations \\
\hline & 20 & Endemics \\
\hline & 21 & Introductions \\
\hline & 22 & Endangered Species \\
\hline & 23 & Extinctions \\
\hline & 24 & Vegetation Cover \\
\hline & 25 & Loss of Cover \\
\hline & 26 & Habitat Fragmentation \\
\hline & 27 & Degradation \\
\hline & 28 & Terrestrial Reserves \\
\hline
\end{tabular}


Table A-3 (continued)

\begin{tabular}{|l|l|l|}
\hline \multicolumn{3}{|c|}{ Environmental Vulnerability Index } \\
\hline & 29 & Marine Reserves \\
\hline 30 & Intensive Farming \\
\hline & 31 & Fertilizers \\
\hline 32 & Pesticides \\
\hline 33 & Biotechnology \\
\hline 34 & Productivity Overfishing \\
\hline 35 & Fishing Effort \\
\hline 36 & Renewable Water \\
\hline 37 & Sulphur Dioxide Emissions \\
\hline 38 & Waste Production \\
\hline 39 & Waste Treatment \\
\hline 40 & Industry \\
\hline 41 & Spills \\
\hline 42 & Mining \\
\hline 43 & Sanitation \\
\hline 44 & Vehicles \\
\hline Human Population & 45 & Population \\
\hline 46 & Population Growth \\
\hline 47 & Tourists \\
\hline 48 & Coastal Settlements \\
\hline 49 & Environmental Agreements \\
\hline 50 & Conflicts \\
\hline
\end{tabular}

\section{Sustainable Development Index (SDI)}

Developed by: Consultative Group on Sustainable Development Indicators at the International Institute for Sustainable Development (IISD).

http://www.iisd.org/cgsdi/

The following information has been copied from: Pavel Nováček and Peter Mederly. Global Partnership for Development. American Council for United Nations University, May 2002:

The index should cover the significant aspects of sustainable development. As the four UNCSD recommended areas of sustainable development (environmental, social, economic, institutional) do not cover all the aspects, seven major topics were selected:

- Human rights, freedom, and equality

- Demographic development and life expectancy

- Health conditions and health care

- Education, technologies, and information 
- Economic development and foreign indebtedness

- Resource consumption, eco-efficiency

- Environmental quality, environmental problems

The variables were selected on the following criteria:

- relevance to the indicator, as well as coherence with sustainable development;

- long-term observation and evaluation of the variable, data available for the last several years, and the possibility to extrapolate trends;

- data available at least for 100 countries (with some exceptions); and

- minimization of the number of data sources used, because it is desirable to use one source of information for most of the variables.

Fifty-eight variables had been selected; the number of variables for one indicator varied from three to six (an average of four variables by indicator). The construction of sub-indices and the overall index is a key methodological problem. Advantages and disadvantages of individual variable weight was considered. But because the mutual relationships among the variables and their significance are not yet known at this stage of the study, it was decided to weight all variables equally. The final index is therefore an arithmetical average of all the variables. Determining the weight is a task for the next step in the evolution of the SD Index, based on multidimensional data analysis and finding correlation between individual variables.

The SDI is comprised of the following topics and sub-topics:

Table A-4: Components of the SDI

Source: Adapted from Nováček, et al.,, 2002.

Sustainable Development Index (SDI)

\begin{tabular}{|c|c|}
\hline \multirow[t]{2}{*}{ 1. Human rights, freedom and equality } & A. Politics and human rights \\
\hline & B. Equality \\
\hline \multirow[t]{2}{*}{ 2. Demographic and life expectancy } & C. Demography issues \\
\hline & D. Life expectancy \\
\hline \multirow[t]{2}{*}{ 3. Health and health care } & E. Health care \\
\hline & F. Diseases and nutrition \\
\hline \multirow[t]{2}{*}{ 4. Education, technology, and information } & G. Education \\
\hline & H. Technologies and access to information \\
\hline \multirow{2}{*}{$\begin{array}{l}\text { 5. Economic development and foreign } \\
\text { indebtedness }\end{array}$} & I. Economy \\
\hline & K. Indebtedness \\
\hline \multirow[t]{2}{*}{ 6. Resource consumption } & L. Economy-genuine savings \\
\hline & M. Economy-resource consumption \\
\hline \multirow[t]{2}{*}{ 7. Environmental issues } & N. Environment-natural resources, land use \\
\hline & O. Environment-urban and rural problems \\
\hline
\end{tabular}




\section{Wellbeing Index (WI)}

Developed by: Robert Prescott-Allen

Prescott-Allen, R. 2001. The Wellbeing of Nations: A Country-by-Country Index of Quality of Life and the Environment. Washington, DC: Island Press.

The following information has been copied from a summary of the event: The Wellbeing of Nations: Developing Tools for Measuring Sustainable Development,. Featuring Robert PrescottAllen, PADATA and author of The Wellbeing of Nations; Thomas E. Lovejoy, Lead Environmental Specialist for Latin America and the Caribbean, The World Bank (introduction); and Melinda Kimble, Senior Vice-President for Programs, UN Foundation (discussant). October 11, 2001. Available at: http://wilsoncenter.org/index.cfm?topic id=1413\&fuseaction=topics.event summary\&event id $=6852$ :

While 'sustainability' and 'sustainable development' are two of the key concepts for 21st century national and global policymaking, the terms often evoke glazed eyes and lip service, according to researcher and consultant Robert Prescott-Allen. To reinvigorate and sharpen these concepts, Prescott-Allen has invented several indices of human and ecosystem well-being that he says are much broader (and more precise) yardsticks of progress and health than such well-known indicators as the Gross Domestic Product or the Human Development Index. Prescott-Allen introduced his findings and his new Island Press book, The Wellbeing of Nations: A Country-byCountry Index of Quality of Life and the Environment, to a Wilson Center audience of population, development aid, and environment experts...

Prescott-Allen, who has founded and chaired several influential IUCN-The World Conservation Union projects and has 18 years experience evaluating and advising development strategies on four continents, said that every society should continually ask itself two questions: How sustainable are we? And how well are we? To answer these questions, Prescott-Allen said, we need a formal assessment method to provide clear numeric measurements that can be the basis for policy and can build public consensus for action.

Prescott-Allen defined "sustainability" (which he said is just another way of saying "the good life") as a combination of (a) a high level of human well-being, and (b) the high level of ecosystem well-being that supports it. Much as the white of an egg surrounds and supports its yolk, Prescott-Allen said, an ecosystem surrounds and supports people. Any measure of well-being, therefore, must reflect this interdependence...

But why aren't present indices adequate for measuring the state of the world? Prescott-Allen argued that human well-being is both more than the strength of a market economy (which is what GDP measures) or a society's distance from deprivation (as measured by the Human Development Index). Instead, he said, human well-being consists of five dimensions:

- Long lives in good health and a stable population base;

- Wealth to secure basic needs and livelihoods as well as to promote enterprise and prosperity;

- Knowledge to live sustainably and fulfill potential as well as a vibrant culture;

- A community that upholds the freedom of members, has an open and clean government, and which is safe from violence and crime; 
- Benefits that are shared equally by males and females and shared equitably among all strata of society.

Similarly, Prescott-Allen said that ecosystem well-being is more than low resource consumption (so it cannot be adequately measured by The Ecological Footprint) as well as more than the sum of a nation's environmental policies and practices (as measured by the Environmental Sustainability Index). Ecosystem well-being, according to Prescott-Allen, also has five dimensions:

- Conserving the diversity and quality of the natural land ecosystem;

- Conserving the diversity and quality of water ecosystems;

- Restoring the chemical balance of global atmosphere and the quality of local air;

- Maintaining all wild species and the genes in domesticated species;

- Keeping resource use within the carrying-capacity of ecosystems.

How To Measure Well-Being

The Wellbeing of Nations contains an exhaustive breakdown of each of these dimensions into the indicators that Prescott-Allen uses to develop his indices. The problem for any such work, Prescott-Allen said, is to convert these 'apples and oranges' indicator measurements into common units.

Instead of using the inherently-limited options of physical units or money, Prescott-Allen opted for performance scores, which are the distance between a standard and the actual performance of a country. Using international targets, national standards, and expert opinions to set his myriad performance standards, Prescott-Allen then mapped each country's performances onto a 0-100 scale-making it 'readily comprehensible to a wide range of lay people,' he said. The numeric scale also allows each score to be summed-for example, water withdrawal, inland water quality, and river conversion can be added to give a cumulative inland waters index for each country. 'We can instantly see how any country is performing on any given indicator,' said Prescott-Allen.

\section{Happy Planet Index (HPI) \\ Developed by: New Economics Foundation http://www.neweconomics.org}

The following information has been copied from: Happy Planet Index website (accessed in April 2009). http://www.happyplanetindex.org/about.htm:

The Happy Planet Index (HPI) is an innovative new measure that shows the ecological efficiency with which human well-being is delivered around the world. It is the first ever index to combine environmental impact with well-being to measure the environmental efficiency with which country by country, people live long and happy lives.

The Index doesn't reveal the 'happiest' country in the world. It shows the relative efficiency with which nations convert the planet's natural resources into long and happy lives for their citizens. The nations that top the Index aren't the happiest places in the world, but the nations that score well show that achieving, long, happy lives without over-stretching the planet's resources is 
possible. The HPI shows that around the world, high levels of resource consumption do not reliably produce high levels of well-being (life-satisfaction), and that it is possible to produce high levels of well-being without excessive consumption of the Earth's resources. It also reveals that there are different routes to achieving comparable levels of well-being. The model followed by the West can provide widespread longevity and variable life satisfaction, but it does so only at a vast and ultimately counter-productive cost in terms of resource consumption...

How it is calculated

The HPI reflects the average years of happy life produced by a given society, nation or group of nations, per unit of planetary resources consumed. Put another way, it represents the efficiency with which countries convert the earth's finite resources into well-being experienced by their citizens.

The Global HPI incorporates three separate indicators: ecological footprint, life-satisfaction and life expectancy.

Conceptually, it is straight forward and intuitive:

$$
\mathrm{HPI}=\frac{\text { Life satisfaction } x \text { Life expectancy }}{\text { Ecological Footprint }+\alpha} \times \beta
$$

(For details of how alpha and beta are calculated, see the appendix in the full Happy Planet Index report)

Life satisfaction

Extensive research has been conducted in psychology and the social sciences to understand the factors influencing well-being. Nevertheless, it is only relatively recently that subjective measures of well-being have begun to be taken seriously outside academia. In the UK there has been a groundswell of interest in the potential of subjective well-being measures both from within government and from those such as nef seeking to inform and influence policy from outside. However, just as there is controversy over whether IQ tests really measure intelligence, there is considerable debate over whether self-reports of life satisfaction have anything to do with real 'well-being'. Yet, self-reports of life satisfaction are considered valid if they correlate reliably with predicted objective indicators that are thought to be associated with well-being. Most academics working on well-being are satisfied that ratings of life satisfaction within a country or culture are acceptably valid. An individual's self-reported life satisfaction correlates with reports from loved ones, with how often they experience good moods, and even the likelihood they will commit suicide later on in their life. People with positive self-perceptions also tend to live longer than those who regard themselves more negatively. As well as being valid, self-reports of life satisfaction seem to be reliable. In other words, people tend to give the same patterns of response over time, and when slightly different question wordings are used.

Some researchers notably those from an economics background tend to see happiness, life satisfaction and well-being as synonymous and interchangeable. But there are important and clearly discernable differences. Satisfaction with life overall, tends to be generally stable since it reflects a summary of "judgements about feelings". Whilst on the individual level, day-to-day changes in happiness are of interest, at a policy level it is overall satisfaction that gives the best 
indication of how groups of people are faring. If a majority of people in a country report dissatisfaction with their lives, this seems to be a reasonable indication that something is awry, either with government policy, with society, or with both.

International surveys tend to consider life satisfaction by asking respondents a question such as: 'If you consider your life overall, how satisfied would you say you are nowadays?' Responses are given on a 010 scale, from not at all satisfied to extremely satisfied. Clearly this is not a perfect measure. Ideally, subjective well-being would be assessed by asking a series of questions, perhaps probing different aspects of life and framing the issue in different ways so as to gain a more complete picture. As a general indicator of the state of well-being in a country, however, this single question performs surprisingly well, showing good validity when compared with other national-level statistics.

\section{The Happy Planet Index: What it reveals}

On a scale of 0 to 100 for the $\mathrm{HPI}$, we have set a reasonable target for nations to aspire to of 83.5. This is based on attainable levels of life expectancy and well-being and a reasonably sized ecological footprint.

At this point in time, the highest HPI is only 68.2, scored by the Pacific archipelago of Vanuatu. The lowest, and perhaps less surprising than some other results, is Zimbabwe's at 16.6. No country achieves an overall high score and no country does well on all three indicators. Vanuatu, for example, has only a moderate level of life expectancy at 69 years.

The message is that when we measure the efficiency with which countries enable the fundamental inputs of natural resources to be turned into the ultimate ends of long and happy lives, all can do better.

This conclusion is less surprising in the light of our argument that governments have been concentrating on the wrong indicators for too long. If you have the wrong map, you are unlikely to reach your destination.

Some of the most unexpected findings of the HPI concern the marked differences between nations, and the similarities among some groups of nations:

Island nations score well above average in the Index: They have higher life satisfaction, higher life expectancy and marginally lower Footprints than other states. Yet incomes (by GDP per capita) are roughly equal to the world average. Even within regions, islands do well. Malta tops the Western world with Cyprus in seventh place (out of 24); the top five HPI nations in Africa are all islands; as well as two of the top four in Asia. Perhaps a more acute awareness of environmental limits has sometimes helped their societies to bond better and to adapt to get more from less. Combined with the enhanced well-being that stems from close contact with nature, the world as a whole stands to learn much from the experience of islands.

It is possible to live long, happy lives with a much smaller environmental impact: For example, in the United States and Germany people's sense of life satisfaction is almost identical and life expectancy is broadly similar. Yet Germany's Ecological footprint is only about half that of the USA. This means that Germany is around twice as efficient as the USA at generating happy long lives based on the resources that they consume. Ecological footprint is only about half that of the 
USA. This means that Germany is around twice as efficient as the USA at generating happy long lives based on the resources that they consume.

\section{Why do we need the Happy Planet Index?}

In the Western world, economics is at the heart of our thinking about most issues. When we talk of growth or development, we are typically thinking about the distribution and flow of money. A nation's progress is also most commonly measured in terms of GDP. Defined as the total value of a country's annual output of goods and services. GDP is the standard measure of economic activity and the key headline indicator for government policy in the vast majority of countries.

GDP was never intended to function as an indicator of well-being. Even the economist Simon Küznets, a central figure in the development of GDP, in 1934 urged the US Congress to remember "The welfare of a nation can scarcely be inferred from a measurement of national income." Yet, until quite recently, it has routinely been assumed to be a reliable proxy for standard of living.

The logic underlying this was that- growth in GDP implies economic activity, which in turn implies that people are spending money and improving their quality of life. But GDP turns out to be a poor indicator of welfare in several key respects. For a start, interpreting it as a standard-of-living measure means assuming that income is strongly correlated with national well-being, such that all else being equal general well-being will increase as the economy grows. It has been repeatedly proven in recent years that this is simply not true. Undoubtedly, a relationship exists between income and well-being, but after a certain, surprisingly low level of GDP is reached, the strength of this relationship declines markedly.

GDP is also insensitive to the distribution of income within countries. A country with high rates of poverty, a small but affluent elite, and high exports could have a similar GDP per capita to one with comparably little inequality and a thriving domestic economy. GDP also fails to distinguish money spent correcting or compensating for undesirable events. This can lead to some apparently perverse results. For example, it has been estimated that the Enron accounting scandal may have contributed up to $\$ 1$ billion to US GDP. Natural disasters - hurricanes, floods and so on -also tend to boost GDP, because huge amounts of public money are typically spent in mitigating the resulting damage. From an environmental perspective this is a disastrous oversight - GDP counts resource consumption, but takes no account whatsoever of the extent to which it can be maintained, or its real cost.

\section{Quality of Life Index (QOL)}

Developed by: The Economist Intelligence Unit http://www.eiu.com/

"The Economist Intelligence Unit has developed a new 'quality of life' index based on a unique methodology that links the results of subjective life-satisfaction surveys to the objective determinants of quality of life across countries." Quoted from 'The Economist Intelligence Unit's quality-of-life Index.' See the entire document at http://www.economist.com/media/pdf/QUALITY OF LIFE.PDF for a full overview.

The QOL uses the following factors/weights: 
Table A-5: Components of the QLI

Source: Adapted from The Economist Intelligence Unit.

\begin{tabular}{|l|r|}
\hline \multicolumn{1}{|c|}{ Quality of Life Index (QLI) } & Weight \% \\
\hline Material wellbeing & 18.8 \\
\hline Health & 19 \\
\hline Family relations & 11.3 \\
\hline Job security & 7.7 \\
\hline Social and community activities & 12.2 \\
\hline Political freedom and security & 26.2 \\
\hline Gender equality & 4.7 \\
\hline
\end{tabular}




\section{Appendix B: Original Sources for Metrics Taken from the Earth Trends Portal}

\section{Table B-1: Original Sources for Metrics Taken from the Earth Trends Portal}

Source: Compiled by the author.

\begin{tabular}{|l|l|}
\hline \multicolumn{1}{|c|}{ Metric } & \multicolumn{1}{c|}{ Original Source $^{35}$} \\
\hline $\begin{array}{l}\text { Total population, both } \\
\text { sexes }\end{array}$ & $\begin{array}{l}\text { Population Division of the Department of Economic and Social Affairs of the United Nations Secretariat. } \\
\text { 2007. World Population Prospects: The 2006 Revision. Dataset on CD-ROM. New York: United Nations. }\end{array}$ \\
\hline Land: Total area & $\begin{array}{l}\text { Food and Agriculture Organization of the United Nations (FAO). 2008. FAOSTAT Online Statistical Service. } \\
\text { Rome: FAO. }\end{array}$ \\
\hline Civil liberties index & $\begin{array}{l}\text { Freedom House. 2007. Freedom in the World 2007: The Annual Survey of Political Rights and Civil } \\
\text { Liberties. New York: Freedom House. }\end{array}$ \\
\hline $\begin{array}{l}\text { Control of Corruption } \\
\text { Index }\end{array}$ & $\begin{array}{l}\text { Governance Matters VII: Aggregate and Individual Governance Indicators, 1996-2007. D. Kaufmann, A. } \\
\text { Kraay, and M. Mastruzzi (2008). World Bank Policy Research Working Paper 4654. }\end{array}$ \\
\hline Level of freedom index & $\begin{array}{l}\text { Freedom House. 2007. Freedom in the World 2007: The Annual Survey of Political Rights and Civil } \\
\text { Liberties. New York: Freedom House. }\end{array}$ \\
\hline Political rights index & $\begin{array}{l}\text { Freedom House. 2007. Freedom in the World 2007: The Annual Survey of Political Rights and Civil } \\
\text { Liberties. New York: Freedom House. }\end{array}$ \\
\hline $\begin{array}{l}\text { Political Stability and } \\
\text { Absence of Violence } \\
\text { Index }\end{array}$ & $\begin{array}{l}\text { Governance Matters VII: Aggregate and Individual Governance Indicators, 1996-2007. D. Kaufmann, A. } \\
\text { Kraay, and M. Mastruzzi (2008). World Bank Policy Research Working Paper 4654. }\end{array}$ \\
\hline Press freedom index & $\begin{array}{l}\text { Freedom House. 2007. Freedom of the Press 2007: A Global Survey of Media Independence. New York: } \\
\text { Freedom House. }\end{array}$ \\
\hline $\begin{array}{l}\text { Regulatory Quality } \\
\text { Index }\end{array}$ & $\begin{array}{l}\text { Governance Matters VII: Aggregate and Individual Governance Indicators, 1996-2007. D. Kaufmann, A. } \\
\text { Kraay, and M. Mastruzzi (2008). World Bank Policy Research Working Paper 4654. }\end{array}$ \\
\hline $\begin{array}{l}\text { Religious freedom } \\
\text { index }\end{array}$ & $\begin{array}{l}\text { Freedom House, Center for Religious Freedom. 2000. Religious Freedom in the World: A Global Survey of } \\
\text { Religious Freedom and Persecution. Washington: Freedom House. }\end{array}$ \\
\hline
\end{tabular}

35 "TRANSFORMED TO PER CAPITA" indicates that the metric has been divided by population using figures from: Population Division of the Department of Economic and Social Affairs of the United Nations Secretariat. 2007. World Population Prospects: The 2006 Revision. Dataset on CDROM. New York: United Nations. "TRANSFORMED TO PER LAND AREA" indicates that the metric has been divided by land area using figures from: Food and Agriculture Organization of the United Nations (FAO). 2008. FAOSTAT Online Statistical Service. Rome: FAO. 
Table B-1 (continued)

\begin{tabular}{|c|c|}
\hline Metric & Original Source \\
\hline Rule of Law Index & $\begin{array}{l}\text { Governance Matters VII: Aggregate and Individual Governance Indicators, 1996-2007. D. Kaufmann, A. } \\
\text { Kraay, and M. Mastruzzi (2008). World Bank Policy Research Working Paper 4654. }\end{array}$ \\
\hline $\begin{array}{l}\text { Transnational } \\
\text { Corporations: Foreign } \\
\text { direct investment, net } \\
\text { inflows }\end{array}$ & $\begin{array}{l}\text { Development Data Group, The World Bank. 2008. } 2008 \text { World Development Indicators Online. } \\
\text { Washington, DC: The World Bank. TRANSFORMED TO PER CAPITA. }\end{array}$ \\
\hline $\begin{array}{l}\text { Transnational } \\
\text { Corporations: Number } \\
\text { of foreign affiliates }\end{array}$ & $\begin{array}{l}\text { United Nations Conference on Trade and Development (UNCTAD). 2006. World Investment Report } 2006 \text { - } \\
\text { FDI from Developing and Transition Economies: Implications for Development. Annex Table A.I.6. Number } \\
\text { of parent corporations and foreign affiliates, by region and economy, latest available year.â€ New York } \\
\text { and Geneva: UNCTAD. TRANSFORMED TO PER CAPITA. }\end{array}$ \\
\hline $\begin{array}{l}\text { Transnational } \\
\text { Corporations: Number } \\
\text { of parent enterprises }\end{array}$ & $\begin{array}{l}\text { United Nations Conference on Trade and Development (UNCTAD). 2006. World Investment Report } 2006 \text { - } \\
\text { FDI from Developing and Transition Economies: Implications for Development. Annex Table A.I.6. Number } \\
\text { of parent corporations and foreign affiliates, by region and economy, latest available year.â€ New York } \\
\text { and Geneva: UNCTAD. TRANSFORMED TO PER CAPITA. }\end{array}$ \\
\hline $\begin{array}{l}\text { Investment in } \\
\text { telecommunications }\end{array}$ & $\begin{array}{l}\text { International Telecommunication Union (ITU). 2007. World Telecommunication Indicators 2006. Geneva: } \\
\text { ITU. TRANSFORMED TO PER CAPITA. }\end{array}$ \\
\hline $\begin{array}{l}\text { Density of international } \\
\text { non-governmental } \\
\text { organizations with } \\
\text { membership }\end{array}$ & $\begin{array}{l}\text { Center for the Study of Global Governance. 2004. Global Civil Society 2004/5. H. Anheier et al., eds. } \\
\text { London: Sage. }\end{array}$ \\
\hline $\begin{array}{l}\text { Corruption: Bribe } \\
\text { Payer's Index }\end{array}$ & Transparency International. 2006. 2006 Bribe Payer's Index. Berlin: Transparency International. \\
\hline $\begin{array}{l}\text { Corruption perceptions } \\
\text { index }\end{array}$ & $\begin{array}{l}\text { Internet Center for Corruption Research. 2006. Corruption Perceptions Index. Berlin: Internet Center for } \\
\text { Corruption Research. }\end{array}$ \\
\hline $\begin{array}{l}\text { Present value of debt } \\
\text { as a percent of GNI }\end{array}$ & $\begin{array}{l}\text { Development Data Group, The World Bank. 2008. } 2008 \text { World Development Indicators Online. } \\
\text { Washington, DC: The World Bank. }\end{array}$ \\
\hline
\end{tabular}


Table B-1 (continued)

\begin{tabular}{|l|l|}
\hline \multicolumn{1}{|c|}{ Metric } & \multicolumn{1}{c|}{ Original Source } \\
\hline Total debt service & $\begin{array}{l}\text { Development Data Group, The World Bank. 2008. 2008 World Development Indicators Online. } \\
\text { Washington, DC: The World Bank. TRANSFORMED TO PER CAPITA. }\end{array}$ \\
\hline $\begin{array}{l}\text { Total debt service as a } \\
\text { percent of export } \\
\text { earnings }\end{array}$ & $\begin{array}{l}\text { Development Data Group, The World Bank. 2008. 2008 World Development Indicators Online. } \\
\text { Washington, DC: The World Bank. TRANSFORMED TO PER CAPITA. }\end{array}$ \\
\hline $\begin{array}{l}\text { Total external debt } \\
\text { (External )Aid as a } \\
\text { percent of government } \\
\text { expenditure }\end{array}$ & $\begin{array}{l}\text { Development Data Group, The World Bank. 2008. 2008 World Development Indicators Online. } \\
\text { Washington, DC: The World Bank. TRANSFORMED TO PER CAPITA. }\end{array}$ \\
\hline $\begin{array}{l}\text { Aid (received) per } \\
\text { capita }\end{array}$ & $\begin{array}{l}\text { Development Data Group, The World Bank. 2008. 2008 World Development Indicators Online. } \\
\text { Washington, DC: The World Bank. }\end{array}$ \\
\hline $\begin{array}{l}\text { Government cash } \\
\text { deficit/surplus as a } \\
\text { percent of GDP }\end{array}$ & $\begin{array}{l}\text { Development Data Group, The World Bank. 2008. 2008 World Development Indicators Online. } \\
\text { Washington, DC: The World Bank. }\end{array}$ \\
\hline $\begin{array}{l}\text { Government } \\
\text { consumption } \\
\text { expenditure as a } \\
\text { percent of GDP }\end{array}$ & $\begin{array}{l}\text { Development Data Group, The World Bank. 2008. 2008 World Development Indicators Online. } \\
\text { Washington, DC: The World Bank. }\end{array}$ \\
\hline $\begin{array}{l}\text { Military expenditure as } \\
\text { a percent of GDP }\end{array}$ & $\begin{array}{l}\text { Development Data Group, The World Bank. 2008. 2008 World Development Indicators Online. } \\
\text { Washington, DC: The World Bank. }\end{array}$ \\
\hline $\begin{array}{l}\text { Military expenditure as } \\
\text { a percent of } \\
\text { government } \\
\text { expenditure }\end{array}$ & $\begin{array}{l}\text { Development Data Group, The World Bank. 2008. 2008 World Development Indicators Online. } \\
\text { Washington, DC: The World Bank. }\end{array}$ \\
\hline
\end{tabular}


Table B-1 (continued)

\begin{tabular}{|c|c|}
\hline Metric & Original Source \\
\hline $\begin{array}{l}\text { Public education } \\
\text { expenditure as a } \\
\text { percent of GDP }\end{array}$ & $\begin{array}{l}\text { Development Data Group, The World Bank. 2008. } 2008 \text { World Development Indicators Online. } \\
\text { Washington, DC: The World Bank }\end{array}$ \\
\hline $\begin{array}{l}\text { Public health } \\
\text { expenditure as a } \\
\text { percent of GDP }\end{array}$ & $\begin{array}{l}\text { Development Data Group, The World Bank. 2008. } 2008 \text { World Development Indicators Online. } \\
\text { Washington, DC: The World Bank. }\end{array}$ \\
\hline $\begin{array}{l}\text { Cost to register } \\
\text { property }\end{array}$ & The World Bank Group. 2007. Doing Business Custom Datasets. Washington, DC: The World Bank \\
\hline $\begin{array}{l}\text { Cost to start a new } \\
\text { business }\end{array}$ & The World Bank Group. 2007. Doing Business Custom Datasets. Washington, DC: The World Bank. \\
\hline $\begin{array}{l}\text { Time required to } \\
\text { register property }\end{array}$ & The World Bank Group. 2007. Doing Business Custom Datasets. Washington, DC: The World Bank. \\
\hline $\begin{array}{l}\text { Time required to start a } \\
\text { new business }\end{array}$ & The World Bank Group. 2007. Doing Business Custom Datasets. Washington, DC: The World Bank. \\
\hline Water Poverty Index & $\begin{array}{l}\text { Natural Environment Research Council, Centre for Ecology and Hydrology. 2002. The Water Poverty Index: } \\
\text { International Comparisons. Wallingford: Centre for Ecology and Hydrology. }\end{array}$ \\
\hline $\begin{array}{l}\text { Organic water } \\
\text { pollutant (BOD) } \\
\text { emissions }\end{array}$ & $\begin{array}{l}\text { Development Data Group, The World Bank. 2006. } 2006 \text { World Development Indicators Online. } \\
\text { Washington, DC: The World Bank. TRANSFORMED TO PER CAPITA. }\end{array}$ \\
\hline $\begin{array}{l}\text { Internal Renewable } \\
\text { Water Resources } \\
\text { (IRWR): Dependency } \\
\text { ratio }\end{array}$ & $\begin{array}{l}\text { Food and Agriculture Organization of the United Nations (FAO) Land and Water Development Division. } \\
\text { 2007. AQUASTAT Information System on Water and Agriculture: Online database. Rome: FAO. }\end{array}$ \\
\hline $\begin{array}{l}\text { Access to an improved } \\
\text { water source }\end{array}$ & $\begin{array}{l}\text { World Health Organization (WHO) and United Nation's Children's Fund (UNICEF). 2006. Meeting the MDG } \\
\text { Drinking Water and Sanitation Target: The Urban and Rural Challenge of the Decade. Geneva: WHO and } \\
\text { New York: UNICEF. }\end{array}$ \\
\hline
\end{tabular}


Table B-1 (continued)

\begin{tabular}{|c|c|}
\hline Metric & Original Source \\
\hline $\begin{array}{l}\text { Access to improved } \\
\text { sanitation }\end{array}$ & $\begin{array}{l}\text { World Health Organization (WHO) and United Nation's Children's Fund (UNICEF). 2006. Meeting the MDG } \\
\text { Drinking Water and Sanitation Target: The Urban and Rural Challenge of the Decade. Geneva: WHO and } \\
\text { New York: UNICEF. }\end{array}$ \\
\hline $\begin{array}{l}\text { Rural access to an } \\
\text { improved water source }\end{array}$ & $\begin{array}{l}\text { World Helath Organization (WHO) and United Nation's Children's Fund (UNICEF). 2006. Meeting the MDG } \\
\text { Drinking Water and Sanitation Target: The Urban and Rural Challenge of the Decade. Geneva: WHO and } \\
\text { New York: UNICEF. }\end{array}$ \\
\hline $\begin{array}{l}\text { Rural access to } \\
\text { improved sanitation }\end{array}$ & $\begin{array}{l}\text { World Helath Organization (WHO) and United Nation's Children's Fund (UNICEF). 2006. Meeting the MDG } \\
\text { Drinking Water and Sanitation Target: The Urban and Rural Challenge of the Decade. Geneva: WHO and } \\
\text { New York: UNICEF. }\end{array}$ \\
\hline $\begin{array}{l}\text { Urban access to an } \\
\text { improved water source }\end{array}$ & $\begin{array}{l}\text { World Helath Organization (WHO) and United Nation's Children's Fund (UNICEF). 2006. Meeting the MDG } \\
\text { Drinking Water and Sanitation Target: The Urban and Rural Challenge of the Decade. Geneva: WHO and } \\
\text { New York: UNICEF. }\end{array}$ \\
\hline $\begin{array}{l}\text { Urban access to } \\
\text { improved sanitation }\end{array}$ & $\begin{array}{l}\text { World Health Organization (WHO) and United Nation's Children's Fund (UNICEF). 2006. Meeting the MDG } \\
\text { Drinking Water and Sanitation Target: The Urban and Rural Challenge of the Decade. Geneva: WHO and } \\
\text { New York: UNICEF. }\end{array}$ \\
\hline $\begin{array}{l}\text { Carbon monoxide } \\
\text { emissions }\end{array}$ & $\begin{array}{l}\text { The Netherlands National Institute for Public Health and the Environment/The Netherlands Environmental } \\
\text { Assessment Agency (RIVM/MNP) and the Netherlands Organization for Applied Scientific Research (TNO). } \\
2005 \text { and 2001. The Emission Database for Global Atmospheric Research (EDGAR) } 3.2 \text { Fast Track } 2000 \text { and } \\
\text { 3.2. Precursors: CO (Carbon Monoxide): Extended Emissions } 2000 \text { and Aggregated Emissions 1990/1995. } \\
\text { The Netherlands: RIVM. TRANSFORMED TO PER CAPITA. }\end{array}$ \\
\hline $\begin{array}{l}\text { Nitrogen oxides } \\
\text { emissions }\end{array}$ & $\begin{array}{l}\text { The Netherlands National Institute for Public Health and the Environment/The Netherlands Environmental } \\
\text { Assessment Agency (RIVM/MNP) and the Netherlands Organization for Applied Scientific Research (TNO). } \\
2005 \text { and 2001. The Emission Database for Global Atmospheric Research (EDGAR) } 3.2 \text { Fast Track } 2000 \text { and } \\
\text { 3.2. Precursors: NOx (Nitrogen Oxides): Extended Emissions } 2000 \text { and Aggregated Emissions 1990/1995. } \\
\text { The Netherlands: RIVM. TRANSFORMED TO PER CAPITA. }\end{array}$ \\
\hline
\end{tabular}


Table B-1 (continued)

\begin{tabular}{|c|c|}
\hline Metric & Original Source \\
\hline $\begin{array}{l}\text { Non-methane VOC } \\
\text { emissions }\end{array}$ & $\begin{array}{l}\text { The Netherlands National Institute for Public Health and the Environment/The Netherlands Environmental } \\
\text { Assessment Agency (RIVM/MNP) and the Netherlands Organization for Applied Scientific Research (TNO). } \\
2005 \text { and 2001. The Emission Database for Global Atmospheric Research (EDGAR) } 3.2 \text { Fast Track } 2000 \text { and } \\
\text { 3.2. Precursors: NMVOC (Non-Methane Volatile Organic Compounds): Extended Emissions } 2000 \text { and } \\
\text { Aggregated Emissions 1990/1995. The Netherlands: RIVM. TRANSFORMED TO PER CAPITA. }\end{array}$ \\
\hline $\begin{array}{l}\text { Sulfur dioxide } \\
\text { emissions }\end{array}$ & $\begin{array}{l}\text { The Netherlands National Institute for Public Health and the Environment/The Netherlands Environmental } \\
\text { Assessment Agency (RIVM/MNP) and the Netherlands Organization for Applied Scientific Research (TNO). } \\
2005 \text { and 2001. The Emission Database for Global Atmospheric Research (EDGAR) 3.2 Fast Track } 2000 \text { and } \\
\text { 3.2. Acidifying gases: SO2 (Sulfur Dioxide): Extended Emissions } 2000 \text { and Aggregated Emissions } \\
\text { 1990/1995. The Netherlands: RIVM. TRANSFORMED TO PER CAPITA. }\end{array}$ \\
\hline $\begin{array}{l}\text { Cumulative emissions } \\
\text { from land use change }\end{array}$ & $\begin{array}{l}\text { Climate Analysis Indicators Tool (CAIT) version 3.0. (Washington, DC: World Resources Institute, 2005). } \\
\text { TRANSFORMED TO PER CAPITA. }\end{array}$ \\
\hline $\begin{array}{l}\text { CO2 emissions per } \\
\text { capita }\end{array}$ & Climate Analysis Indicators Tool (CAIT) version 3.0. (Washington, DC: World Resources Institute, 2005). \\
\hline $\begin{array}{l}\text { Residential CO2 } \\
\text { emissions per capita }\end{array}$ & $\begin{array}{l}\text { International Energy Agency (IEA) Statistics Division. 2006. CO2 Emissions from Fuel Combustion ( } 2006 \\
\text { edition). Paris: IEA. / Population Division of the Department of Economic and Social Affairs of the United } \\
\text { Nations Secretariat, 2005. World Population Prospects: The } 2004 \text { Revision. Dataset on CD-ROM. New } \\
\text { York: United Nations. }\end{array}$ \\
\hline CO2 emissions per GDP & $\begin{array}{l}\text { Climate Analysis Indicators Tool (CAIT) version 5.0. (Washington, DC: World Resources Institute, 2005). / } \\
\text { EIA. 2005. International Energy Annual 2005. / IEA. 2004. CO2 Emissions from Fuel Combustion (2004 } \\
\text { edition). / Marland, G., T.A. Boden, and R. J. Andres. 2005. Global, Regional, and National Fossil Fuel CO2 } \\
\text { Emissions. in Trends: A Compendium of Data on Global Change. Carbon Dioxide Information Analysis } \\
\text { Center, Oak Ridge National Laboratory, U.S. Department of Energy, Oak Ridge, Tenn., U.S.A. } \\
\text { TRANSFORMED TO PER CAPITA USING GDP PER CAPITA. }\end{array}$ \\
\hline
\end{tabular}


Table B-1 (continued)

\begin{tabular}{|c|c|}
\hline Metric & Original Source \\
\hline $\begin{array}{l}\text { Non-CO2 Greenhouse } \\
\text { Gas Emissions: } \\
\text { Fluorinated gases }\end{array}$ & $\begin{array}{l}\text { Climate Analysis Indicators Tool (CAIT), version 3.0. (Washington, DC: World Resources Institute, 2005). / } \\
\text { EPA. 2004. Personal communications based on Global Non-CO2 Greenhouse Gas Emissions: } 1990 \text { - 2020. / } \\
\text { EDGAR 3.2 by RIVM/TNO. 2003. (Olivier, J.G.J. and Berdowski, J.J.M., 2001, Global emission sources and } \\
\text { sinks. In: J. Berdowski, R. Guicherit and B.J. Heij, eds. The Climate System: 33-78. Lisse: Swets \& Zeitlinger } \\
\text { Publishers). TRANSFORMED TO PER CAPITA. }\end{array}$ \\
\hline $\begin{array}{l}\text { Non-CO2 Greenhouse } \\
\text { Gas Emissions: } \\
\text { Methane }\end{array}$ & $\begin{array}{l}\text { Climate Analysis Indicators Tool (CAIT), version 3.0. (Washington, DC: World Resources Institute, 2005). / } \\
\text { EPA. 2004. Personal communications based on Global Non-CO2 Greenhouse Gas Emissions: } 1990 \text { - 2020. / } \\
\text { EDGAR 3.2 by RIVM/TNO. 2003. (Olivier, J.G.J. and Berdowski, J.J.M., 2001, Global emission sources and } \\
\text { sinks. In: J. Berdowski, R. Guicherit and B.J. Heij, eds. The Climate System: 33-78. Lisse: Swets \& Zeitlinger } \\
\text { Publishers). TRANSFORMED TO PER CAPITA. }\end{array}$ \\
\hline $\begin{array}{l}\text { Non-CO2 Greenhouse } \\
\text { Gas Emissions: Nitrous } \\
\text { oxide }\end{array}$ & $\begin{array}{l}\text { Climate Analysis Indicators Tool (CAIT), version 3.0. (Washington, DC: World Resources Institute, 2005). / } \\
\text { EPA. 2004. Personal communications based on Global Non-CO2 Greenhouse Gas Emissions: } 1990-2020 . \\
\text { / EDGAR } 3.2 \text { by RIVM/TNO. 2003. (Olivier, J.G.J. and Berdowski, J.J.M., 2001, Global emission sources and } \\
\text { sinks. In: J. Berdowski, R. Guicherit and B.J. Heij, eds. The Climate System: 33-78. Lisse: Swets \& Zeitlinger } \\
\text { Publishers). TRANSFORMED TO PER CAPITA. }\end{array}$ \\
\hline $\begin{array}{l}\text { Cellular mobile } \\
\text { telephone subscribers } \\
\text { per } 1000 \text { people }\end{array}$ & $\begin{array}{l}\text { International Telecommunication Union (ITU). 2007. World Telecommunication Indicators 2006. Geneva: } \\
\text { ITU. }\end{array}$ \\
\hline $\begin{array}{l}\text { Homes with personal } \\
\text { computers }\end{array}$ & $\begin{array}{l}\text { International Telecommunication Union (ITU). 2006. World Telecommunication Indicators 2005. Geneva: } \\
\text { ITU. }\end{array}$ \\
\hline Homes with telephones & $\begin{array}{l}\text { International Telecommunication Union (ITU). 2006. World Telecommunication Indicators 2005. Geneva: } \\
\text { ITU. }\end{array}$ \\
\hline $\begin{array}{l}\text { Internet users per } 1000 \\
\text { people }\end{array}$ & $\begin{array}{l}\text { International Telecommunication Union (ITU). 2007. World Telecommunication Indicators 2006. Geneva: } \\
\text { ITU. }\end{array}$ \\
\hline $\begin{array}{l}\text { Television sets per } \\
1000 \text { people }\end{array}$ & $\begin{array}{l}\text { International Telecommunication Union (ITU). 2007. World Telecommunication Indicators 2006. Geneva: } \\
\text { ITU. }\end{array}$ \\
\hline
\end{tabular}


Table B-1 (continued)

\begin{tabular}{|c|c|}
\hline Metric & Original Source \\
\hline $\begin{array}{l}\text { AIDS/HIV: } \\
\text { Antiretroviral therapy } \\
\text { coverage }\end{array}$ & $\begin{array}{l}\text { World Health Organization (WHO) and Joint United Nations Programme on HIV/AIDS (UNAIDS). } 2006 . \\
\text { Progress on Global Access to HIV Antiretroviral Therapy: A Report on "3 by } 5 \text { " and Beyond. Geneva: } \\
\text { WHO/UNAIDS. }\end{array}$ \\
\hline $\begin{array}{l}\text { AIDS/HIV: Adults and } \\
\text { children living with HIV }\end{array}$ & $\begin{array}{l}\text { Joint United Nations Programme on HIV/AIDS (UNAIDS). 2006. Report on the global AIDS epidemic. } \\
\text { Geneva: UNAIDS. }\end{array}$ \\
\hline $\begin{array}{l}\text { Average annual } \\
\text { reduction in under-5 } \\
\text { mortality }\end{array}$ & $\begin{array}{l}\text { United Nations Children's Fund (UNICEF). 2006. The State of the World's Children 2007: The Double } \\
\text { Dividend of Gender Equality. Table 10. New York: UNICEF. }\end{array}$ \\
\hline Infant mortality rate & $\begin{array}{l}\text { United Nations Children's Fund (UNICEF). 2006. The State of the World's Children 2007: The Double } \\
\text { Dividend of Gender Equality. Table 1. New York: UNICEF. / United Nations Children's Fund (UNICEF). } 2006 . \\
\text { Childinfo.org: Monitoring the Situation of Children and Women. Child Mortality statistical database. New } \\
\text { York: UNICEF. }\end{array}$ \\
\hline $\begin{array}{l}\text { Stunting in children } \\
\text { under } 5 \text {--moderate and } \\
\text { severe }\end{array}$ & $\begin{array}{l}\text { United Nations Children's Fund (UNICEF). 2006. The State of the World's Children 2007: The Double } \\
\text { Dividend of Gender Equality. Table 2. New York: UNICEF. }\end{array}$ \\
\hline Under-5 mortality rate & $\begin{array}{l}\text { United Nations Children's Fund (UNICEF). 2006. The State of the World's Children 2007: The Double } \\
\text { Dividend of Gender Equality. Tables } 1 \text { and 10. New York: UNICEF. / United Nations Children's Fund } \\
\text { (UNICEF). 2006. Childinfo.org: Monitoring the Situation of Children and Women. Child Mortality statistical } \\
\text { database. New York: UNICEF. }\end{array}$ \\
\hline $\begin{array}{l}\text { Underweight children } \\
\text { under } 5 \text {--moderate and } \\
\text { severe }\end{array}$ & $\begin{array}{l}\text { United Nations Children's Fund (UNICEF). 2006. The State of the World's Children 2007: The Double } \\
\text { Dividend of Gender Equality. Table 2. New York: UNICEF. }\end{array}$ \\
\hline $\begin{array}{l}\text { Wasting in children } \\
\text { under } 5 \text {--moderate and } \\
\text { severe }\end{array}$ & $\begin{array}{l}\text { United Nations Children's Fund (UNICEF). 2006. The State of the World's Children 2007: The Double } \\
\text { Dividend of Gender Equality. Table 2. New York: UNICEF. }\end{array}$ \\
\hline Crude birth rate & $\begin{array}{l}\text { Population Division of the Department of Economic and Social Affairs of the United Nations Secretariat. } \\
\text { 2007. World Population Prospects: The } 2006 \text { Revision. Dataset on CD-ROM. New York: United Nations. }\end{array}$ \\
\hline
\end{tabular}


Table B-1 (continued)

\begin{tabular}{|c|c|}
\hline Metric & Original Source \\
\hline Crude death rate & $\begin{array}{l}\text { Population Division of the Department of Economic and Social Affairs of the United Nations Secretariat. } \\
\text { 2007. World Population Prospects: The } 2006 \text { Revision. Dataset on CD-ROM. New York: United Nations. }\end{array}$ \\
\hline $\begin{array}{l}\text { Life expectancy at } \\
\text { birth, both sexes }\end{array}$ & $\begin{array}{l}\text { Population Division of the Department of Economic and Social Affairs of the United Nations Secretariat, } \\
\text { 2007. World Population Prospects: The } 2006 \text { Revision. Dataset on CD-ROM. New York: United Nations. }\end{array}$ \\
\hline $\begin{array}{l}\text { Net number of } \\
\text { migrants }\end{array}$ & $\begin{array}{l}\text { Population Division of the Department of Economic and Social Affairs of the United Nations Secretariat, } \\
\text { 2007. World Population Prospects: The } 2006 \text { Revision. Dataset on CD-ROM. New York: United Nations. }\end{array}$ \\
\hline Total fertility rate & $\begin{array}{l}\text { Population Division of the Department of Economic and Social Affairs of the United Nations Secretariat. } \\
\text { 2007. World Population Prospects: The } 2006 \text { Revision. Dataset on CD-ROM. New York: United Nations }\end{array}$ \\
\hline $\begin{array}{l}\text { Internally displaced } \\
\text { persons }\end{array}$ & $\begin{array}{l}\text { Internal Displacement Monitoring Centre, Norwegian Refugee Council. 2006. Internal Displacement: } \\
\text { Global Overview of Trends and Developments in 2005. Geneva: Norwegian Refugee Council. } \\
\text { TRANSFORMED TO PER CAPITA. }\end{array}$ \\
\hline $\begin{array}{l}\text { Average length of } \\
\text { schooling, both sexes }\end{array}$ & $\begin{array}{l}\text { United Nations Educational, Scientific, and Cultural Organization (UNESCO) Institute for Statistics. } 2006 . \\
\text { World Education Indicators. Paris: UNESCO. }\end{array}$ \\
\hline $\begin{array}{l}\text { Primary school net } \\
\text { enrollment ratio }\end{array}$ & $\begin{array}{l}\text { United Nations Educational, Scientific, and Cultural Organization (UNESCO) Institute for Statistics. } 2006 . \\
\text { World Education Indicators. Paris: UNESCO. }\end{array}$ \\
\hline $\begin{array}{l}\text { Secondary school } \\
\text { gender parity in gross } \\
\text { enrollment }\end{array}$ & $\begin{array}{l}\text { United Nations Educational, Scientific, and Cultural Organization (UNESCO) Institute for Statistics. } 2006 . \\
\text { World Education Indicators. Paris: UNESCO. }\end{array}$ \\
\hline $\begin{array}{l}\text { Secondary school net } \\
\text { enrollment ratio }\end{array}$ & $\begin{array}{l}\text { United Nations Educational, Scientific, and Cultural Organization (UNESCO) Institute for Statistics. } 2006 . \\
\text { World Education Indicators. Paris: UNESCO. }\end{array}$ \\
\hline $\begin{array}{l}\text { Tertiary school gross } \\
\text { enrollment ratio, } \\
\text { female }\end{array}$ & $\begin{array}{l}\text { United Nations Educational, Scientific, and Cultural Organization (UNESCO) Institute for Statistics. } 2006 . \\
\text { World Education Indicators. Paris: UNESCO. }\end{array}$ \\
\hline $\begin{array}{l}\text { Lack of Durability of } \\
\text { Housing }\end{array}$ & $\begin{array}{l}\text { United Nations Human Settlements Programme (UN-HABITAT). 2003. Slums of the World: The face of } \\
\text { urban poverty in the new millennium?. }\end{array}$ \\
\hline $\begin{array}{l}\text { \% Owner Occupied } \\
\text { Housing Units, Rural }\end{array}$ & $\begin{array}{l}\text { United Nations Human Settlements Programme (UN-HABITAT). 2001. Global Report on Human } \\
\text { Settlements: Statistical Annexes. }\end{array}$ \\
\hline
\end{tabular}


Table B-1 (continued)

\begin{tabular}{|c|c|}
\hline Metric & Original Source \\
\hline $\begin{array}{l}\text { \% Owner Occupied } \\
\text { Housing Units, Urban }\end{array}$ & $\begin{array}{l}\text { United Nations Human Settlements Programme (UN-HABITAT). 2001. Global Report on Human } \\
\text { Settlements: Statistical Annexes. }\end{array}$ \\
\hline $\begin{array}{l}\text { Lack of Sufficient Living } \\
\text { Area }\end{array}$ & $\begin{array}{l}\text { United Nations Human Settlements Programme (UN-HABITAT). 2003. Slums of the World: The face of } \\
\text { urban poverty in the new millennium? }\end{array}$ \\
\hline $\begin{array}{l}\text { Percent of urban } \\
\text { population living in } \\
\text { slums }\end{array}$ & $\begin{array}{l}\text { United Nations Human Settlements Programme (UN-HABITAT). 2003. Slums of the World: The face of } \\
\text { urban poverty in the new millennium? }\end{array}$ \\
\hline $\begin{array}{l}\text { Women Headed } \\
\text { Households, Percent of } \\
\text { Total }\end{array}$ & $\begin{array}{l}\text { United Nations Human Settlements Programme (UN-HABITAT). 2001. Global Report on Human } \\
\text { Settlements: Statistical Annexes. }\end{array}$ \\
\hline $\begin{array}{l}\text { Agricultural labor force } \\
\text { as a percent of total } \\
\text { labor force }\end{array}$ & $\begin{array}{l}\text { Food and Agriculture Organization of the United Nations (FAO). 2006. FAOSTAT Online Statistical Service. } \\
\text { Rome: FAO. }\end{array}$ \\
\hline $\begin{array}{l}\text { Female professional } \\
\text { and technical workers, } \\
\text { percent of total }\end{array}$ & $\begin{array}{l}\text { United Nations Development Programme (UNDP). 2007. Human Development Report 2007. New York: } \\
\text { UNDP. }\end{array}$ \\
\hline $\begin{array}{l}\text { Female literacy rate as } \\
\text { a percentage of male } \\
\text { literacy rate }\end{array}$ & $\begin{array}{l}\text { United Nations Educational, Scientific, and Cultural Organization (UNESCO) Institute for Statistics. } 2006 . \\
\text { World Education Indicators, Literacy Statistics. Paris: UNESCO }\end{array}$ \\
\hline Literacy rate, all adults & $\begin{array}{l}\text { United Nations Educational, Scientific, and Cultural Organization (UNESCO) Institute for Statistics. } 2006 . \\
\text { World Education Indicators, Literacy Statistics. Paris: UNESCO. }\end{array}$ \\
\hline $\begin{array}{l}\text { Literacy rate, youth } \\
\text { (age } 15 \text { to } 24 \text { ) }\end{array}$ & $\begin{array}{l}\text { United Nations Educational, Scientific, and Cultural Organization (UNESCO) Institute for Statistics. } 2006 . \\
\text { World Education Indicators, Literacy Statistics. Paris: UNESCO }\end{array}$ \\
\hline $\begin{array}{l}\text { Population above age } \\
65 \text {, both sexes }\end{array}$ & $\begin{array}{l}\text { Population Division of the Department of Economic and Social Affairs of the United Nations Secretariat, } \\
\text { 2005. World Population Prospects: The } 2004 \text { Revision. Dataset on CD-ROM. New York: United Nations. } \\
\text { TRANSFORMED TO PER CAPITA. }\end{array}$ \\
\hline
\end{tabular}


Table B-1 (continued)

\begin{tabular}{|c|c|}
\hline Metric & Original Source \\
\hline $\begin{array}{l}\text { Population below age } \\
15 \text {, both sexes }\end{array}$ & $\begin{array}{l}\text { Population Division of the Department of Economic and Social Affairs of the United Nations Secretariat, } \\
\text { 2005. World Population Prospects: The } 2004 \text { Revision. Dataset on CD-ROM. New York: United Nations. } \\
\text { TRANSFORMED TO PER CAPITA. }\end{array}$ \\
\hline $\begin{array}{l}\text { Growth rate of total } \\
\text { population }\end{array}$ & $\begin{array}{l}\text { Population Division of the Department of Economic and Social Affairs of the United Nations Secretariat. } \\
\text { 2007. World Population Prospects: The } 2006 \text { Revision. Dataset on CD-ROM. New York: United Nations. }\end{array}$ \\
\hline Population density & $\begin{array}{l}\text { Population Division of the Department of Economic and Social Affairs of the United Nations Secretariat, } \\
\text { 2007. World Population Prospects: The } 2006 \text { Revision. Dataset on CD-ROM. New York: United Nations. }\end{array}$ \\
\hline $\begin{array}{l}\text { Alcohol consumption } \\
\text { per capita }\end{array}$ & World Health Organization (WHO). 2005. Global Alcohol Database. Geneva: WHO. \\
\hline $\begin{array}{l}\text { Contraceptive } \\
\text { prevalence rate }\end{array}$ & $\begin{array}{l}\text { Department of Economic and Social Affairs, United Nations Population Division (UNPD). 2005. World } \\
\text { Contraceptive Use. New York: UNPD. }\end{array}$ \\
\hline $\begin{array}{l}\text { Women with unmet } \\
\text { need for family } \\
\text { planning }\end{array}$ & $\begin{array}{l}\text { Department of Economic and Social Affairs, United Nations Population Division (UNPD). 2005. World } \\
\text { Contraceptive Use. New York: UNPD. }\end{array}$ \\
\hline $\begin{array}{l}\text { Government } \\
\text { expenditure on health } \\
\text { as a percent of total } \\
\text { expenditure on health }\end{array}$ & World Health Organization (WHO). 2006. World Health Report 2006: Annex Table 2. Geneva: WHO. \\
\hline $\begin{array}{l}\text { Per capita total } \\
\text { expenditure on health }\end{array}$ & World Health Organization (WHO). 2006. World Health Report 2006: Annex Table 3. Geneva: WHO. \\
\hline Solid fuel use & World Health Organization (WHO). 2006. Global Health Atlas: World Health Statistics. Geneva: WHO. \\
\hline $\begin{array}{l}\text { Passenger cars per } \\
1000 \text { people }\end{array}$ & $\begin{array}{l}\text { Development Data Group, The World Bank. 2006. } 2006 \text { World Development Indicators Online. } \\
\text { Washington, DC: The World Bank. }\end{array}$ \\
\hline $\begin{array}{l}\text { Deaths due to road } \\
\text { accidents }\end{array}$ & $\begin{array}{l}\text { International Road Federation (IRF). 2002. World Road Statistics } 2002 \text { on CD-ROM, Table 7. Geneva: } \\
\text { International Road Federation. }\end{array}$ \\
\hline $\begin{array}{l}\text { Pump prices for diesel } \\
\text { fuel }\end{array}$ & The World Bank. 2004. World Development Indicators 2004 (The World Bank, Washington, D.C.) \\
\hline
\end{tabular}


Table B-1 (continued)

\begin{tabular}{|c|c|}
\hline Metric & Original Source \\
\hline $\begin{array}{l}\text { Pump prices for super } \\
\text { gasoline }\end{array}$ & The World Bank. 2004. World Development Indicators 2004. (The World Bank, Washington, D.C.) \\
\hline $\begin{array}{l}\text { Road traffic, million } \\
\text { vehicle-kilometers }\end{array}$ & $\begin{array}{l}\text { International Road Federation (IRF). 2002. World Road Statistics } 2002 \text { on CD-ROM, Table 5A. Geneva: } \\
\text { International Road Federation. }\end{array}$ \\
\hline Total road network & $\begin{array}{l}\text { International Road Federation (IRF). 2002. World Road Statistics } 2002 \text { on CD-ROM, Table 1. Geneva: } \\
\text { International Road Federation. TRANSFORMED TO PER CAPITA. }\end{array}$ \\
\hline $\begin{array}{l}\text { Total vehicles per } \mathrm{km} \\
\text { road }\end{array}$ & $\begin{array}{l}\text { International Road Federation (IRF). 2002. World Road Statistics } 2002 \text { on CD-ROM, Table 4. Geneva: } \\
\text { International Road Federation. TRANSFORMED TO PER CAPITA. }\end{array}$ \\
\hline $\begin{array}{l}\text { Volume of public road } \\
\text { transport }\end{array}$ & $\begin{array}{l}\text { International Road Federation (IRF). 2002. World Road Statistics } 2002 \text { on CD-ROM, Table 5B. Geneva: } \\
\text { International Road Federation. TRANSFORMED TO PER CAPITA. }\end{array}$ \\
\hline $\begin{array}{l}\text { Growth rate of rural } \\
\text { population }\end{array}$ & $\begin{array}{l}\text { United Nations, Department of Economic and Social Affairs, Population Division. 2006. World } \\
\text { Urbanization Prospects: The } 2005 \text { Revision. Urban and Rural Areas Dataset } \\
\text { (POP/DB/WUP/Rev.2005/1/Table A.3), dataset in digital form. }\end{array}$ \\
\hline $\begin{array}{l}\text { Growth rate of urban } \\
\text { population }\end{array}$ & $\begin{array}{l}\text { United Nations, Department of Economic and Social Affairs, Population Division. 2006. World } \\
\text { Urbanization Prospects: The } 2005 \text { Revision. Urban and Rural Areas Dataset } \\
\text { (POP/DB/WUP/Rev.2005/1/Table A.6), dataset in digital form. }\end{array}$ \\
\hline $\begin{array}{l}\text { Total population in } \\
\text { cities with more than } \\
100,000 \text { inhabitants }\end{array}$ & $\begin{array}{l}\text { The World Bank Group. 2004. Urban Population in World Bank Regions by City Size. Washington, DC: } \\
\text { World Bank. TRANSFORMED TO PER CAPITA. }\end{array}$ \\
\hline $\begin{array}{l}\text { Total population in } \\
\text { cities with more than } \\
\text { one million inhabitants }\end{array}$ & $\begin{array}{l}\text { The World Bank Group. 2004. Urban Population in World Bank Regions by City Size. Washington, DC: } \\
\text { World Bank. TRANSFORMED TO PER CAPITA. }\end{array}$ \\
\hline $\begin{array}{l}\text { Urban population as a } \\
\text { percent of total } \\
\text { population }\end{array}$ & $\begin{array}{l}\text { United Nations, Department of Economic and Social Affairs, Population Division. 2006. World } \\
\text { Urbanization Prospects: The } 2005 \text { Revision. Urban and Rural Areas Dataset } \\
\text { (POP/DB/WUP/Rev.2005/1/Table A.2), dataset in digital form. New York: United Nations. }\end{array}$ \\
\hline
\end{tabular}


Table B-1 (continued)

\begin{tabular}{|c|c|}
\hline Metric & Original Source \\
\hline $\begin{array}{l}\text { Share of total } \\
\text { household } \\
\text { expenditure, education }\end{array}$ & $\begin{array}{l}\text { World Resources Institute (WRI) and the International Finance Corporation (IFC), 2007. Next Four Billion: } \\
\text { Market Size \& Business Strategy at the Base of the Pyramid. Washington, D.C.: WRI. }\end{array}$ \\
\hline $\begin{array}{l}\text { Base of the Pyramid: } \\
\text { Share of total } \\
\text { household } \\
\text { expenditure, energy }\end{array}$ & $\begin{array}{l}\text { World Resources Institute (WRI) and the International Finance Corporation (IFC), 2007. Next Four Billion: } \\
\text { Market Size \& Business Strategy at the Base of the Pyramid. Washington, D.C.: WRI. }\end{array}$ \\
\hline $\begin{array}{l}\text { Base of the Pyramid: } \\
\text { Share of total } \\
\text { household } \\
\text { expenditure, food }\end{array}$ & $\begin{array}{l}\text { World Resources Institute (WRI) and the International Finance Corporation (IFC), 2007. Next Four Billion: } \\
\text { Market Size \& Business Strategy at the Base of the Pyramid. Washington, D.C.: WRI. }\end{array}$ \\
\hline $\begin{array}{l}\text { Base of the Pyramid: } \\
\text { Share of total } \\
\text { household } \\
\text { expenditure, health }\end{array}$ & $\begin{array}{l}\text { World Resources Institute (WRI) and the International Finance Corporation (IFC), 2007. Next Four Billion: } \\
\text { Market Size \& Business Strategy at the Base of the Pyramid. Washington, D.C.: WRI. }\end{array}$ \\
\hline $\begin{array}{l}\text { Base of the Pyramid: } \\
\text { Share of total } \\
\text { household } \\
\text { expenditure, } \\
\text { household goods }\end{array}$ & $\begin{array}{l}\text { World Resources Institute (WRI) and the International Finance Corporation (IFC), 2007. Next Four Billion: } \\
\text { Market Size \& Business Strategy at the Base of the Pyramid. Washington, D.C.: WRI. }\end{array}$ \\
\hline $\begin{array}{l}\text { Base of the Pyramid: } \\
\text { Share of total } \\
\text { household } \\
\text { expenditure, housing }\end{array}$ & $\begin{array}{l}\text { World Resources Institute (WRI) and the International Finance Corporation (IFC), 2007. Next Four Billion: } \\
\text { Market Size \& Business Strategy at the Base of the Pyramid. Washington, D.C.: WRI. }\end{array}$ \\
\hline
\end{tabular}


Table B-1 (continued)

\begin{tabular}{|c|c|}
\hline Metric & Original Source \\
\hline $\begin{array}{l}\text { Base of the Pyramid: } \\
\text { Share of total } \\
\text { household } \\
\text { expenditure, } \\
\text { information and } \\
\text { communication } \\
\text { technology }\end{array}$ & $\begin{array}{l}\text { World Resources Institute (WRI) and the International Finance Corporation (IFC), 2007. Next Four Billion: } \\
\text { Market Size \& Business Strategy at the Base of the Pyramid. Washington, D.C.: WRI. }\end{array}$ \\
\hline $\begin{array}{l}\text { Base of the Pyramid: } \\
\text { Share of total } \\
\text { household } \\
\text { expenditure, } \\
\text { transportation }\end{array}$ & $\begin{array}{l}\text { World Resources Institute (WRI) and the International Finance Corporation (IFC), 2007. Next Four Billion: } \\
\text { Market Size \& Business Strategy at the Base of the Pyramid. Washington, D.C.: WRI. }\end{array}$ \\
\hline $\begin{array}{l}\text { Base of the Pyramid: } \\
\text { Share of total } \\
\text { household } \\
\text { expenditure, water }\end{array}$ & $\begin{array}{l}\text { World Resources Institute (WRI) and the International Finance Corporation (IFC), 2007. Next Four Billion: } \\
\text { Market Size \& Business Strategy at the Base of the Pyramid. Washington, D.C.: WRI. }\end{array}$ \\
\hline $\begin{array}{l}\text { Development } \\
\text { Assistance: Aid } \\
\text { received as a percent } \\
\text { of GNI }\end{array}$ & $\begin{array}{l}\text { Development Data Group, The World Bank. 2008. } 2008 \text { World Development Indicators Online. } \\
\text { Washington, DC: The World Bank. }\end{array}$ \\
\hline $\begin{array}{l}\text { Financial Flows: Net } \\
\text { Inflows (sales - } \\
\text { purchases) of Cross- } \\
\text { Border Mergers and } \\
\text { Acquisitions }\end{array}$ & $\begin{array}{l}\text { United Nations Conference on Trade and Development (UNCTAD). 2005. World Investment Report 2005: } \\
\text { Transnational Corporations and the Internationalization of R\&D. Annex Table "B.4. Cross-border M\&As, by } \\
\text { region/economy of seller/purchaser, 2002-2004.â€ New York and Geneva: UNCTAD. TRANSFORMED TO } \\
\text { PER CAPITA. }\end{array}$ \\
\hline $\begin{array}{l}\text { GDP per capita, annual } \\
\text { growth rate }\end{array}$ & $\begin{array}{l}\text { Development Data Group, The World Bank. 2008. } 2008 \text { World Development Indicators Online. } \\
\text { Washington, DC: The World Bank. }\end{array}$ \\
\hline
\end{tabular}


Table B-1 (continued)

\begin{tabular}{|c|c|}
\hline Metric & Original Source \\
\hline $\begin{array}{l}\text { GDP per capita, PPP, } \\
\text { current international } \\
\text { dollars }\end{array}$ & $\begin{array}{l}\text { Development Data Group, The World Bank. 2008. } 2008 \text { World Development Indicators Online. } \\
\text { Washington, DC: The World Bank. }\end{array}$ \\
\hline $\begin{array}{l}\text { GDP: Official exchange } \\
\text { rate }\end{array}$ & $\begin{array}{l}\text { Development Data Group, The World Bank. 2008. } 2008 \text { World Development Indicators Online. } \\
\text { Washington, DC: The World Bank. }\end{array}$ \\
\hline $\begin{array}{l}\text { Percent GDP from } \\
\text { agriculture }\end{array}$ & $\begin{array}{l}\text { Development Data Group, The World Bank. 2008. } 2008 \text { World Development Indicators Online. } \\
\text { Washington, DC: The World Bank. }\end{array}$ \\
\hline $\begin{array}{l}\text { Percent GDP from } \\
\text { industry }\end{array}$ & $\begin{array}{l}\text { Development Data Group, The World Bank. 2008. } 2008 \text { World Development Indicators Online. } \\
\text { Washington, DC: The World Bank. }\end{array}$ \\
\hline $\begin{array}{l}\text { Percent GDP from } \\
\text { manufacturing }\end{array}$ & $\begin{array}{l}\text { Development Data Group, The World Bank. 2008. } 2008 \text { World Development Indicators Online. } \\
\text { Washington, DC: The World Bank. }\end{array}$ \\
\hline $\begin{array}{l}\text { Percent GDP from } \\
\text { services }\end{array}$ & $\begin{array}{l}\text { Development Data Group, The World Bank. 2008. } 2008 \text { World Development Indicators Online. } \\
\text { Washington, DC: The World Bank. }\end{array}$ \\
\hline $\begin{array}{l}\text { GNI: PPP, current } \\
\text { international dollars }\end{array}$ & $\begin{array}{l}\text { Development Data Group, The World Bank. 2008. } 2008 \text { World Development Indicators Online. } \\
\text { Washington, DC: The World Bank. }\end{array}$ \\
\hline $\begin{array}{l}\text { Income Equality: Gini } \\
\text { Index }\end{array}$ & $\begin{array}{l}\text { Development Data Group, The World Bank. 2008. } 2008 \text { World Development Indicators Online. } \\
\text { Washington, DC: The World Bank. }\end{array}$ \\
\hline $\begin{array}{l}\text { Share of total income, } \\
\text { highest } 20 \% \text { of } \\
\text { population }\end{array}$ & $\begin{array}{l}\text { Development Data Group, The World Bank. 2008. } 2008 \text { World Development Indicators Online. } \\
\text { Washington, DC: The World Bank. }\end{array}$ \\
\hline $\begin{array}{l}\text { Share of total income, } \\
\text { fourth } 20 \% \text { of } \\
\text { population }\end{array}$ & $\begin{array}{l}\text { Development Data Group, The World Bank. 2008. } 2008 \text { World Development Indicators Online. } \\
\text { Washington, DC: The World Bank. }\end{array}$ \\
\hline $\begin{array}{l}\text { Share of total income, } \\
\text { lowest } 20 \% \text { of } \\
\text { population }\end{array}$ & $\begin{array}{l}\text { Development Data Group, The World Bank. 2008. } 2008 \text { World Development Indicators Online. } \\
\text { Washington, DC: The World Bank. }\end{array}$ \\
\hline
\end{tabular}


Table B-1 (continued)

\section{\begin{tabular}{l|l} 
Metric & Original Source
\end{tabular}}

Share of total income, $\quad$ Development Data Group, The World Bank. 2008. 2008 World Development Indicators Online. second $20 \%$ of Washington, DC: The World Bank.

population

Share of total income, $\quad$ Development Data Group, The World Bank. 2008. 2008 World Development Indicators Online.

third $20 \%$ of population Washington, DC: The World Bank.

Workers' remittances $\quad$ Development Data Group, The World Bank. 2007. 2007 World Development Indicators Online. and compensation of Washington, DC: The World Bank.

employees, paid

Workers' remittances and compensation of employees, received Micro, Small, and

Medium Enterprises:

MSME employment,

percent of total

Micro, Small, and

Medium Enterprises:

MSMEs per 1000

people

Adjusted Net Savings,

percent of GNI

National poverty rates

Development Data Group, The World Bank. 2008. 2008 World Development Indicators Online.

Washington, DC: The World Bank.

Small and Medium Enterprise Department, International Finance Corporation (IFC). 2006. Micro, Small, and Medium Enterprises: A Collection of Published Data. Washington, DC: IFC.

Small and Medium Enterprise Department, International Finance Corporation (IFC). 2006. Micro, Small,

and Medium Enterprises: A Collection of Published Data. Washington, DC: IFC.

National poverty rates, $\quad$ Development Data Group, The World Bank. 2008. 2008 World Development Indicators Online.

rural population

National poverty rates,

urban population

Development Data Group, The World Bank. 2007. 2007 World Development Indicators Online.

Washington, DC: The World Bank.

Development Data Group, The World Bank. 2008. 2008 World Development Indicators Online. Washington, DC: The World Bank.

Washington, DC: The World Bank.

Development Data Group, The World Bank. 2008. 2008 World Development Indicators Online.

Washington, DC: The World Bank. 
Table B-1 (continued)

\begin{tabular}{|l|l|}
\hline \multicolumn{1}{|c|}{ Metric } & \multicolumn{1}{c|}{ Original Source } \\
\hline $\begin{array}{l}\text { International tourism } \\
\text { expenditures }\end{array}$ & $\begin{array}{l}\text { Development Data Group, The World Bank. 2007. 2007 World Development Indicators Online. } \\
\text { Washington, DC: The World Bank. }\end{array}$ \\
\hline $\begin{array}{l}\text { International tourism } \\
\text { receipts }\end{array}$ & $\begin{array}{l}\text { Development Data Group, The World Bank. 2008. 2008 World Development Indicators Online. } \\
\text { Washington, DC: The World Bank. }\end{array}$ \\
\hline $\begin{array}{l}\text { Trade in Forest } \\
\text { Products: Imports, } \\
\text { value }\end{array}$ & $\begin{array}{l}\text { Food and Agriculture Organization of the United Nations (FAO). 2008. FAOSTAT Online Statistical Service. } \\
\text { Rome: FAO. TRANSFORMED TO PER CAPITA. }\end{array}$ \\
\hline $\begin{array}{l}\text { Trade in Goods and } \\
\text { Services: Current } \\
\text { account balance }\end{array}$ & $\begin{array}{l}\text { Development Data Group, The World Bank. 2008. 2008 World Development Indicators Online. } \\
\text { Washington, DC: The World Bank. TRANSFORMED TO PER CAPITA. }\end{array}$ \\
\hline $\begin{array}{l}\text { Trade in Fish and } \\
\text { Fisheries Products: } \\
\text { Exports, quantity }\end{array}$ & $\begin{array}{l}\text { Food and Agriculture Organization of the United Nations (FAO) Fishery Information, Data and Statistics } \\
\text { Unit. 2007. Commodities production and trade 1976-2005. FISHSTAT Plus - Universal software for fishery } \\
\text { statistical time series [online or CD-ROM]. Rome: FAO. TRANSFORMED TO PER CAPITA. }\end{array}$ \\
\hline $\begin{array}{l}\text { Trade in Fish and } \\
\text { Fisheries Products: } \\
\text { Imports, quantity }\end{array}$ & $\begin{array}{l}\text { Food and Agriculture Organization of the United Nations (FAO) Fishery Information, Data and Statistics } \\
\text { Unit. 2007. Commodities production and trade 1976-2005. FISHSTAT Plus - Universal software for fishery } \\
\text { statistical time series [online or CD-ROM]. Rome: FAO. TRANSFORMED TO PER CAPITA. }\end{array}$ \\
\hline $\begin{array}{l}\text { Trade in Goods and } \\
\text { Services: Net trade in } \\
\text { goods and services } \\
\text { (balance of trade) }\end{array}$ & $\begin{array}{l}\text { Development Data Group, The World Bank. 2008. 2008 World Development Indicators Online. } \\
\text { Washington, DC: The World Bank. TRANSFORMED TO PER CAPITA. }\end{array}$ \\
\hline $\begin{array}{l}\text { Trade in Goods: } \\
\text { Agricultural raw } \\
\text { materials exports as a } \\
\text { percent of } \\
\text { merchandise exports }\end{array}$ & $\begin{array}{l}\text { Development Data Group, The World Bank. 2007. 2007 World Development Indicators Online. } \\
\text { Washington, DC: The World Bank. }\end{array}$ \\
\hline
\end{tabular}


Table B-1 (continued)

\begin{tabular}{|c|c|}
\hline Metric & Original Source \\
\hline $\begin{array}{l}\text { Trade in Goods: } \\
\text { Agricultural raw } \\
\text { materials imports as a } \\
\text { percent of } \\
\text { merchandise imports }\end{array}$ & $\begin{array}{l}\text { Development Data Group, The World Bank. 2007. } 2007 \text { World Development Indicators Online. } \\
\text { Washington, DC: The World Bank. }\end{array}$ \\
\hline $\begin{array}{l}\text { Trade in Goods: Food } \\
\text { exports as a percent of } \\
\text { merchandise exports }\end{array}$ & $\begin{array}{l}\text { Development Data Group, The World Bank. 2007. } 2007 \text { World Development Indicators Online. } \\
\text { Washington, DC: The World Bank. }\end{array}$ \\
\hline $\begin{array}{l}\text { Trade in Goods: Food } \\
\text { imports as a percent of } \\
\text { merchandise imports }\end{array}$ & $\begin{array}{l}\text { Development Data Group, The World Bank. 2007. } 2007 \text { World Development Indicators Online. } \\
\text { Washington, DC: The World Bank. }\end{array}$ \\
\hline $\begin{array}{l}\text { Trade in Goods: Fuel } \\
\text { exports as a percent of } \\
\text { merchandise exports }\end{array}$ & $\begin{array}{l}\text { Development Data Group, The World Bank. 2008. } 2008 \text { World Development Indicators Online. } \\
\text { Washington, DC: The World Bank. }\end{array}$ \\
\hline $\begin{array}{l}\text { Trade in Goods: Fuel } \\
\text { imports as a percent of } \\
\text { merchandise imports }\end{array}$ & $\begin{array}{l}\text { Development Data Group, The World Bank. 2008. } 2008 \text { World Development Indicators Online. } \\
\text { Washington, DC: The World Bank. }\end{array}$ \\
\hline $\begin{array}{l}\text { Trade in Goods: } \\
\text { Manufactures exports } \\
\text { as a percent of } \\
\text { merchandise exports }\end{array}$ & $\begin{array}{l}\text { Development Data Group, The World Bank. 2008. } 2008 \text { World Development Indicators Online. } \\
\text { Washington, DC: The World Bank. }\end{array}$ \\
\hline $\begin{array}{l}\text { Trade in Goods: } \\
\text { Manufactures imports } \\
\text { as a percent of } \\
\text { merchandise imports }\end{array}$ & $\begin{array}{l}\text { Development Data Group, The World Bank. 2008. } 2008 \text { World Development Indicators Online. } \\
\text { Washington, DC: The World Bank. }\end{array}$ \\
\hline
\end{tabular}


Table B-1 (continued)

Metric

Electricity consumption

per capita

Total electricity

production

Energy Consumption

by Source: Biogas and

liquid biomass

Energy Consumption

by Source: Coal and

coal products

Energy Consumption

by Source:

Hydroelectric

Energy Consumption

by Source: Natural gas

Energy Consumption

by Source: Oil and

petroleum products

Energy Consumption

by Source: Solar, wind,

and wave

\section{Original Source}

International Energy Agency (IEA) Statistics Division. 2007. Energy Balances of OECD Countries (2008

edition)--Economic Indicators and Energy Balances of Non-OECD Countries (2007 edition)--Economic

Indicators. Paris: IEA.

International Energy Agency (IEA) Statistics Division. 2007. Energy Balances of OECD Countries (2008

edition) and Energy Balances of Non-OECD Countries (2007 edition). Paris: IEA. TRANSFORMED TO PER CAPITA.

International Energy Agency (IEA) Statistics Division. 2008. Energy Balances of OECD Countries (2006

edition) and Energy Balances of Non-OECD Countries (2006 edition). Paris: IEA. TRANSFORMED TO PER CAPITA.

International Energy Agency (IEA) Statistics Division. 2007. Energy Balances of OECD Countries (2008

edition) and Energy Balances of Non-OECD Countries (2007 edition). Paris: IEA. TRANSFORMED TO PER CAPITA.

International Energy Agency (IEA) Statistics Division. 2007. Energy Balances of OECD Countries (2008

edition) and Energy Balances of Non-OECD Countries (2007 edition). Paris: IEA. TRANSFORMED TO PER

CAPITA.

International Energy Agency (IEA) Statistics Division. 2007. Energy Balances of OECD Countries (2008

edition) and Energy Balances of Non-OECD Countries (2007 edition). Paris: IEA. TRANSFORMED TO PER CAPITA.

International Energy Agency (IEA) Statistics Division. 2007. Energy Balances of OECD Countries (2008 edition) and Energy Balances of Non-OECD Countries (2007 edition). Paris: IEA. TRANSFORMED TO PER CAPITA.

International Energy Agency (IEA) Statistics Division. 2006. Energy Balances of OECD Countries (2006 edition) and Energy Balances of Non-OECD Countries (2006 edition). Paris: IEA. TRANSFORMED TO PER CAPITA. 
Table B-1 (continued)

\begin{tabular}{|c|c|}
\hline Metric & Original Source \\
\hline $\begin{array}{l}\text { Energy Consumption } \\
\text { by Source: Solid } \\
\text { biomass (includes } \\
\text { fuelwood) }\end{array}$ & $\begin{array}{l}\text { International Energy Agency (IEA) Statistics Division. 2008. Energy Balances of OECD Countries ( } 2006 \\
\text { edition) and Energy Balances of Non-OECD Countries ( } 2006 \text { edition). Paris: IEA. TRANSFORMED TO PER } \\
\text { CAPITA. }\end{array}$ \\
\hline $\begin{array}{l}\text { Residential energy } \\
\text { consumption per capita }\end{array}$ & $\begin{array}{l}\text { International Energy Agency (IEA) Statistics Division. 2007. Energy Balances of OECD Countries (2008 } \\
\text { edition) and Energy Balances of Non-OECD Countries ( } 2007 \text { edition). Paris: IEA. / Population Division of } \\
\text { the Department of Economic and Social Affairs of the United Nations Secretariat, 2005. World Population } \\
\text { Prospects: The } 2007 \text { Revision. Dataset on CD-ROM. New York: United Nations. }\end{array}$ \\
\hline $\begin{array}{l}\text { Total energy } \\
\text { consumption per capita }\end{array}$ & $\begin{array}{l}\text { International Energy Agency (IEA) Statistics Division. 2007. Energy Balances of OECD Countries ( } 2008 \\
\text { edition) and Energy Balances of Non-OECD Countries ( } 2007 \text { edition). Paris: IEA. }\end{array}$ \\
\hline $\begin{array}{l}\text { Total energy } \\
\text { production }\end{array}$ & $\begin{array}{l}\text { International Energy Agency (IEA) Statistics Division. 2007. Energy Balances of OECD Countries ( } 2008 \\
\text { edition) and Energy Balances of Non-OECD Countries ( } 2007 \text { edition). Paris: IEA. TRANSFORMED TO PER } \\
\text { CAPITA. }\end{array}$ \\
\hline $\begin{array}{l}\text { Paper and paperboard } \\
\text { consumption per capita }\end{array}$ & Food and Agriculture Organization of the United Nations (FAO), 2007. FAOSTAT on-line statistical service. \\
\hline $\begin{array}{l}\text { Diesel oil consumption } \\
\text { per capita }\end{array}$ & $\begin{array}{l}\text { International Energy Agency (IEA) Statistics Division. 2006. Energy Balances of OECD Countries (2006 } \\
\text { edition)---Extended Balances and Energy Balances of Non-OECD Countries (2006 edition)--Extended } \\
\text { Balances. Paris: IEA. }\end{array}$ \\
\hline $\begin{array}{l}\text { Motor gasoline } \\
\text { consumption per capita }\end{array}$ & $\begin{array}{l}\text { International Energy Agency (IEA) Statistics Division. 2006. Energy Balances of OECD Countries (2008 } \\
\text { edition)--Extended Balances and Energy Balances of Non-OECD Countries (2007 edition)--Extended } \\
\text { Balances. Paris: IEA. }\end{array}$ \\
\hline $\begin{array}{l}\text { Protected Areas: IUCN } \\
\text { categories I-V, percent } \\
\text { of total land area }\end{array}$ & $\begin{array}{l}\text { United Nations Environment Programme - World Conservation Monitoring Centre (UNEP-WCMC). } 2006 . \\
\text { World Database on Protected Areas (WDPA). TRANSFORMED TO PER CAPITA. }\end{array}$ \\
\hline
\end{tabular}


Table B-1 (continued)

\begin{tabular}{|c|c|}
\hline Metric & Original Source \\
\hline $\begin{array}{l}\text { Protected Areas: IUCN } \\
\text { categories I-VI and } \\
\text { Other, percent of total } \\
\text { land area }\end{array}$ & $\begin{array}{l}\text { United Nations Environment Programme - World Conservation Monitoring Centre (UNEP-WCMC). } 2006 . \\
\text { World Database on Protected Areas (WDPA). TRANSFORMED TO PER CAPITA. }\end{array}$ \\
\hline $\begin{array}{l}\text { Protected Areas: Larger } \\
\text { than } 100,000 \text { hectares, } \\
\text { number }\end{array}$ & $\begin{array}{l}\text { United Nations Environment Programme - World Conservation Monitoring Centre (UNEP-WCMC). } 2006 . \\
\text { World Database on Protected Areas (WDPA). TRANSFORMED TO PER LAND AREA. }\end{array}$ \\
\hline $\begin{array}{l}\text { Protected Areas: } \\
\text { Marine and Littoral, } \\
\text { number }\end{array}$ & $\begin{array}{l}\text { United Nations Environment Programme - World Conservation Monitoring Centre (UNEP-WCMC). } 2006 . \\
\text { World Database on Protected Areas (WDPA). TRANSFORMED TO PER COASTAL AREA }\end{array}$ \\
\hline Fertilizer use intensity & $\begin{array}{l}\text { Food and Agriculture Organization of the United Nations (FAO). 2007. FAOSTAT Online Statistical Service. } \\
\text { Rome: FAO. }\end{array}$ \\
\hline Pesticide use intensity & $\begin{array}{l}\text { Food and Agriculture Organization of the United Nations (FAO), 2004. FAOSTAT Online Statistical Service. } \\
\text { Rome: FAO. }\end{array}$ \\
\hline $\begin{array}{l}\text { Agricultural Inputs: } \\
\text { Tractor use intensity }\end{array}$ & $\begin{array}{l}\text { Food and Agriculture Organization of the United Nations (FAO). 2006. FAOSTAT Online Statistical Service. } \\
\text { Rome: FAO. }\end{array}$ \\
\hline $\begin{array}{l}\text { Agricultural Inputs: } \\
\text { Water use intensity }\end{array}$ & $\begin{array}{l}\text { Food and Agriculture Organization of the United Nations (FAO) Land and Water Development Division. } \\
\text { 2007. AQUASTAT Information System on Water and Agriculture: Online database. Rome: FAO. / Food and } \\
\text { Agriculture Organization of the United Nations (FAO). 2008. FAOSTAT Online Statistical Service. Rome: } \\
\text { FAO. }\end{array}$ \\
\hline $\begin{array}{l}\text { Food production per } \\
\text { capita index }\end{array}$ & $\begin{array}{l}\text { Food and Agriculture Organization of the United Nations (FAO). 2006. FAOSTAT Online Statistical Service. } \\
\text { Rome: FAO. }\end{array}$ \\
\hline $\begin{array}{l}\text { Agricultural Production } \\
\text { Indices: Total } \\
\text { production per capita } \\
\text { index }\end{array}$ & $\begin{array}{l}\text { Food and Agriculture Organization of the United Nations (FAO). 2006. FAOSTAT Online Statistical Service. } \\
\text { Rome: FAO. }\end{array}$ \\
\hline
\end{tabular}


Table B-1 (continued)

\begin{tabular}{|c|c|}
\hline Metric & Original Source \\
\hline $\begin{array}{l}\text { Agricultural } \\
\text { Production: Cereals, } \\
\text { yield }\end{array}$ & $\begin{array}{l}\text { Food and Agriculture Organization of the United Nations (FAO). 2006. FAOSTAT Online Statistical Service. } \\
\text { Rome: FAO. }\end{array}$ \\
\hline $\begin{array}{l}\text { Agricultural } \\
\text { Production: Cereals, } \\
\text { total production }\end{array}$ & $\begin{array}{l}\text { Food and Agriculture Organization of the United Nations (FAO). 2006. FAOSTAT Online Statistical Service. } \\
\text { Rome: FAO. TRANSFORMED TO PER CAPITA. }\end{array}$ \\
\hline $\begin{array}{l}\text { Agricultural } \\
\text { Production: Roots and } \\
\text { tubers, total } \\
\text { production }\end{array}$ & $\begin{array}{l}\text { Food and Agriculture Organization of the United Nations (FAO). 2006. FAOSTAT Online Statistical Service. } \\
\text { Rome: FAO. }\end{array}$ \\
\hline $\begin{array}{l}\text { Agricultural } \\
\text { Production: Roots and } \\
\text { tubers, yield }\end{array}$ & $\begin{array}{l}\text { Food and Agriculture Organization of the United Nations (FAO). 2006. FAOSTAT Online Statistical Service. } \\
\text { Rome: FAO. }\end{array}$ \\
\hline $\begin{array}{l}\text { Food Aid: Cereals } \\
\text { donated by country }\end{array}$ & $\begin{array}{l}\text { Food and Agriculture Organization of the United Nations (FAO). 2008. FAOSTAT Online Statistical Service. } \\
\text { Rome: FAO. TRANSFORMED TO PER CAPITA. }\end{array}$ \\
\hline $\begin{array}{l}\text { Food Aid: Cereals } \\
\text { received by country }\end{array}$ & $\begin{array}{l}\text { Food and Agriculture Organization of the United Nations (FAO). 2008. FAOSTAT Online Statistical Service. } \\
\text { Rome: FAO. TRANSFORMED TO PER CAPITA. }\end{array}$ \\
\hline $\begin{array}{l}\text { Irrigated land as a } \\
\text { percent of total } \\
\text { agricultural area }\end{array}$ & $\begin{array}{l}\text { Food and Agriculture Organization of the United Nations (FAO). 2006. FAOSTAT Online Statistical Service. } \\
\text { Rome: FAO. }\end{array}$ \\
\hline Cattle stocks & $\begin{array}{l}\text { Food and Agriculture Organization of the United Nations (FAO), 2007. FAOSTAT on-line statistical service. } \\
\text { FAO: Rome. TRANSFORMED TO PER CAPITA. }\end{array}$ \\
\hline Chicken stocks & $\begin{array}{l}\text { Food and Agriculture Organization of the United Nations (FAO), 2007. FAOSTAT on-line statistical service. } \\
\text { FAO: Rome. TRANSFORMED TO PER CAPITA. }\end{array}$ \\
\hline $\begin{array}{l}\text { Equine (horses, mules, } \\
\text { asses) stocks }\end{array}$ & $\begin{array}{l}\text { Food and Agriculture Organization of the United Nations (FAO), 2007. FAOSTAT on-line statistical service. } \\
\text { FAO: Rome. TRANSFORMED TO PER CAPITA. }\end{array}$ \\
\hline
\end{tabular}


Table B-1 (continued)

\begin{tabular}{|c|c|}
\hline Metric & Original Source \\
\hline Goat stocks & $\begin{array}{l}\text { Food and Agriculture Organization of the United Nations (FAO), 2007. FAOSTAT on-line statistical service. } \\
\text { FAO: Rome. TRANSFORMED TO PER CAPITA. }\end{array}$ \\
\hline Sheep stocks & $\begin{array}{l}\text { Food and Agriculture Organization of the United Nations (FAO), 2007. FAOSTAT on-line statistical service. } \\
\text { FAO: Rome. TRANSFORMED TO PER CAPITA. }\end{array}$ \\
\hline Swine stocks & $\begin{array}{l}\text { Food and Agriculture Organization of the United Nations (FAO), 2007. FAOSTAT on-line statistical service. } \\
\text { FAO: Rome. TRANSFORMED TO PER CAPITA. }\end{array}$ \\
\hline Turkey stocks & $\begin{array}{l}\text { Food and Agriculture Organization of the United Nations (FAO), 2007. FAOSTAT on-line statistical service. } \\
\text { FAO: Rome. TRANSFORMED TO PER CAPITA. }\end{array}$ \\
\hline $\begin{array}{l}\text { Meat Consumption: } \\
\text { Per capita }\end{array}$ & $\begin{array}{l}\text { Food and Agriculture Organization of the United Nations (FAO), FAOSTAT on-line statistical service (FAO, } \\
\text { Rome, 2004). }\end{array}$ \\
\hline $\begin{array}{l}\text { Meat production per } \\
\text { capita }\end{array}$ & $\begin{array}{l}\text { Food and Agriculture Organization of the United Nations (FAO). 2008. FAOSTAT Online Statistical Service. } \\
\text { Rome: FAO. }\end{array}$ \\
\hline $\begin{array}{l}\text { Percentage of } \\
\text { population that is } \\
\text { undernourished }\end{array}$ & $\begin{array}{l}\text { Food and Agriculture Organization of the United Nations (FAO), Statistics Division. Food Security Statistics, } \\
2006 .\end{array}$ \\
\hline $\begin{array}{l}\text { Calorie supply per } \\
\text { capita }\end{array}$ & $\begin{array}{l}\text { Food and Agriculture Organization of the United Nations (FAO). 2006. FAOSTAT Online Statistical Service. } \\
\text { Rome: FAO. }\end{array}$ \\
\hline $\begin{array}{l}\text { Calorie supply per } \\
\text { capita from animal } \\
\text { products }\end{array}$ & Food and Agriculture Organization of the United Nations (FAO), FAOSTAT on-line statistical service. \\
\hline $\begin{array}{l}\text { Grain fed to livestock } \\
\text { as a percent of total } \\
\text { grain consumed }\end{array}$ & $\begin{array}{l}\text { United States Department of Agriculture (USDA) Foreign Agricultural Service (FAS). 2007. Production, } \\
\text { Supply \& Distribution Online Database. USDA: Washington, D.C. }\end{array}$ \\
\hline $\begin{array}{l}\text { Number of organic } \\
\text { farms }\end{array}$ & $\begin{array}{l}\text { Willer, Helga and Yussefi, Minou, Eds. 2006. The World of Organic Agriculture - Statistics and Emerging } \\
\text { Trends 2006. International Federation of Organic Agriculture Movements (IFOAM). Bonn, Germany: } \\
\text { IFOAM. TRANSFORMED TO PER CAPITA. }\end{array}$ \\
\hline
\end{tabular}


Table B-1 (continued)

\begin{tabular}{|c|c|}
\hline Metric & Original Source \\
\hline $\begin{array}{l}\text { Organic land area as a } \\
\text { percent of total } \\
\text { agricultural area }\end{array}$ & $\begin{array}{l}\text { Willer, Helga and Yussefi, Minou, Eds. 2006. The World of Organic Agriculture - Statistics and Emerging } \\
\text { Trends 2006. International Federation of Organic Agriculture Movements (IFOAM). Bonn, Germany: } \\
\text { IFOAM. }\end{array}$ \\
\hline $\begin{array}{l}\text { Food exports as a } \\
\text { percent of } \\
\text { merchandise exports }\end{array}$ & $\begin{array}{l}\text { Development Data Group, The World Bank. 2007. } 2007 \text { World Development Indicators Online. } \\
\text { Washington, DC: The World Bank. }\end{array}$ \\
\hline $\begin{array}{l}\text { Dryland area as a } \\
\text { percent of total area, } \\
\text { average }\end{array}$ & $\begin{array}{l}\text { UNEP/GRID. United Nations Environment Program/Global Resource Information Database. 1991. Global } \\
\text { digital data sets for land degradation studies: a GIS approach. Prepared by U. Deichmann and L. Eklundh. } \\
\text { GRID Case Study Series No. 4. UNEP/GEMS and GRID. Nairobi, Kenya. }\end{array}$ \\
\hline $\begin{array}{l}\text { Ecosystem Area: } \\
\text { Barren or sparsely } \\
\text { vegetated area }\end{array}$ & $\begin{array}{l}\text { Loveland, T.R., Reed, B.C., J.F., Brown, J.F., Ohlen, D.O., Zhu, Z., Yang, L. Merchant. J. 2000. Global Land } \\
\text { Cover Characteristics Database (GLCCD) Version 2.0. TRANSFORMED TO PER LAND AREA. }\end{array}$ \\
\hline $\begin{array}{l}\text { Urban and built-up } \\
\text { areas }\end{array}$ & $\begin{array}{l}\text { Global Land Cover } 2000 \text { database. European Commission, Joint Research Centre, 2003. TRANSFORMED } \\
\text { TO PER LAND AREA. }\end{array}$ \\
\hline $\begin{array}{l}\text { Paper Production: } \\
\text { Recovered paper }\end{array}$ & $\begin{array}{l}\text { Food and Agriculture Organization of the United Nations (FAO). 2008. FAOSTAT Online Statistical Service. } \\
\text { Rome: FAO. TRANSFORMED TO PER CAPITA. }\end{array}$ \\
\hline $\begin{array}{l}\text { Paper Production: } \\
\text { Paper and paperboard }\end{array}$ & $\begin{array}{l}\text { Food and Agriculture Organization of the United Nations (FAO). 2008. FAOSTAT Online Statistical Service. } \\
\text { Rome: FAO. TRANSFORMED TO PER CAPITA. }\end{array}$ \\
\hline $\begin{array}{l}\text { Forest area (current) as } \\
\text { a percent of original } \\
\text { forest area }\end{array}$ & $\begin{array}{l}\text { Closed forest data: Bryant, D., D. Nielsen and L. Tangley, "The Last Frontier Forests: Ecosystems and } \\
\text { Economies on the Edge", (World Resources Institute, Washington, DC, 1997). Land area is from Food and } \\
\text { Agriculture Organization of the United Nations (FAO), FAOSTAT On-line Statistical Service. }\end{array}$ \\
\hline $\begin{array}{l}\text { Forest area (original) as } \\
\text { a percent of total land } \\
\text { area }\end{array}$ & $\begin{array}{l}\text { Closed forest data: Bryant, D., D. Nielsen and L. Tangley, "The Last Frontier Forests: Ecosystems and } \\
\text { Economies on the Edge", (World Resources Institute, Washington, DC, 1997). Land area is from Food and } \\
\text { Agriculture Organization of the United Nations (FAO), FAOSTAT On-line Statistical Service, }\end{array}$ \\
\hline $\begin{array}{l}\text { Forest plantations area, } \\
\text { average annual percent } \\
\text { change }\end{array}$ & $\begin{array}{l}\text { Food and Agriculture Organization of the United Nations (FAO). 2005. Global Forest Resources } \\
\text { Assessment 2005: Progress towards sustainable forest management. FAO Forestry Paper 147. Rome: FAO. }\end{array}$ \\
\hline
\end{tabular}


Table B-1 (continued)

\section{Metric}

Frontier forest area as

a percent of original

forest area

Mangrove forest area

Forest Extent: Natural

forest area

Total forest area

Paper and paperboard

consumption per capita

\section{Original Source}

Closed forest data: Bryant, D., D. Nielsen and L. Tangley, "The Last Frontier Forests: Ecosystems and

Economies on the Edge", (World Resources Institute, Washington, DC, 1997). Land area is from Food and Agriculture Organization of the United Nations (FAO), FAOSTAT On-line Statistical Service.

Source: Spalding, M., F. Blasco, and C. Field (Eds.). "World Mangrove Atlas", The International Society for Mangrove Ecosystems (ISME), Okinawa, Japan, 1997. TRANSFORMED TO PER CAPITA.

Food and Agriculture Organization of the United Nations (FAO). 2005. Global Forest Resources

Assessment 2005: Progress towards sustainable forest management. FAO Forestry Paper 147. Rome: FAO. TRANSFORMED TO PER CAPITA.

Food and Agriculture Organization of the United Nations (FAO). 2005. Global Forest Resources

Assessment 2005: Progress towards sustainable forest management. FAO Forestry Paper 147. Rome: FAO.

TRANSFORMED TO PER CAPITA.

Trade in Paper: Food and Agriculture Organization of the United Nations (FAO), 2007. FAOSTAT on-line statistical service. 


\section{Appendix C: Complete List of Statistically Significant Metrics Found in the Analysis}

\section{Table C-1: Complete List of Statistically Significant Metrics Found in the Analysis}

\begin{tabular}{|c|c|c|c|c|c|c|c|c|c|c|c|c|}
\hline \multirow{3}{*}{ Metric } & \multicolumn{9}{|c|}{ Movement Towards the Quadrant } & \multirow{2}{*}{\multicolumn{3}{|c|}{$\begin{array}{l}\text { Present-day } \\
\text { Distance from } \\
\text { Quadrant }\end{array}$}} \\
\hline & \multicolumn{3}{|c|}{ Long -term (80-05) } & \multicolumn{3}{|c|}{ Med.-term (90-05) } & \multicolumn{3}{|c|}{ Short-term (00-05) } & & & \\
\hline & $\mathbf{n}$ & $\mathbf{R}$ & $\mathbf{P}\left(\mathbf{H}_{0}\right)$ & $\mathbf{n}$ & $\mathbf{R}$ & $\mathbf{P}\left(\mathbf{H}_{0}\right)$ & $\mathbf{n}$ & $\mathbf{R}$ & $P\left(H_{0}\right)$ & $\mathbf{n}$ & $\mathbf{R}$ & $\mathbf{P}\left(\mathbf{H}_{0}\right)$ \\
\hline $\begin{array}{l}\text { Access to Information: Cellular mobile } \\
\text { telephone subscribers per } 1000 \text { people }\end{array}$ & 67 & $(0.313)$ & 0.01 & & $\begin{array}{r}\text { Not stati } \\
\text { signifi }\end{array}$ & & 121 & $(0.341)$ & $<0.001$ & & $\begin{array}{l}\text { t statisti } \\
\text { significa }\end{array}$ & \\
\hline $\begin{array}{l}\text { Access to Information: Homes with personal } \\
\text { computers ( } \% \text { of homes) }\end{array}$ & \multicolumn{3}{|c|}{ N/A } & \multicolumn{3}{|c|}{$\begin{array}{l}\text { Not statistically } \\
\text { significant }\end{array}$} & \multicolumn{3}{|c|}{$\begin{array}{l}\text { Not statistically } \\
\text { significant }\end{array}$} & 32 & (0.419) & $<0.05$ \\
\hline $\begin{array}{l}\text { Access to Information: Homes with telephones } \\
\text { (\% of homes) }\end{array}$ & \multicolumn{3}{|c|}{$\begin{array}{l}\text { Not statistically } \\
\text { significant }\end{array}$} & \multicolumn{3}{|c|}{$\begin{array}{l}\text { Not statistically } \\
\text { significant }\end{array}$} & \multicolumn{3}{|c|}{$\begin{array}{l}\text { Not statistically } \\
\text { significant }\end{array}$} & 21 & $(0.402)$ & $<0.1$ \\
\hline $\begin{array}{l}\text { Access to Information: Internet users per } 1000 \\
\text { people }\end{array}$ & \multicolumn{3}{|c|}{ N/A } & \multicolumn{3}{|c|}{$\begin{array}{l}\text { Not statistically } \\
\text { significant }\end{array}$} & 106 & $(0.312)$ & $<0.01$ & \multicolumn{3}{|c|}{$\begin{array}{l}\text { Not statistically } \\
\text { significant }\end{array}$} \\
\hline $\begin{array}{l}\text { Adequate solid waste disposal (\% of total } \\
\text { waste disposal) }\end{array}$ & \multicolumn{3}{|c|}{ N/A } & \multicolumn{3}{|c|}{ N/A } & \multicolumn{3}{|c|}{ N/A } & 27 & $(0.555)$ & $<0.01$ \\
\hline Adult literacy rate (\% aged 15 or older) & \multicolumn{3}{|c|}{ N/A } & \multicolumn{3}{|c|}{ N/A } & \multicolumn{3}{|c|}{ N/A } & 113 & 0.549 & $<0.001$ \\
\hline $\begin{array}{l}\text { Agricultural Inputs: Water use intensity } \\
\left(\mathrm{m}^{3} / \mathrm{ha} / \mathrm{yr}\right)\end{array}$ & \multicolumn{3}{|c|}{ N/A } & \multicolumn{3}{|c|}{ N/A } & \multicolumn{3}{|c|}{ N/A } & 136 & 0.400 & $<0.001$ \\
\hline $\begin{array}{l}\text { Agricultural Production Indices: Food } \\
\text { production per capita index (\% of 1999-2001 } \\
\text { avg. food production per capita) }\end{array}$ & \multicolumn{3}{|c|}{$\begin{array}{l}\text { Not statistically } \\
\text { significant }\end{array}$} & \multicolumn{3}{|c|}{$\begin{array}{l}\text { Not statistically } \\
\text { significant }\end{array}$} & 121 & $(0.292)$ & 0.001 & 142 & 0.375 & $<0.001$ \\
\hline $\begin{array}{l}\text { Base of the Pyramid: Share of total household } \\
\text { expenditure, information and communication } \\
\text { technology (\% of total household expenditure } \\
\text { among those earning less than } \$ 3,000 \\
\text { annually) }\end{array}$ & \multicolumn{3}{|c|}{ N/A } & \multicolumn{3}{|c|}{ N/A } & \multicolumn{3}{|c|}{ N/A } & 35 & 0.527 & $<0.01$ \\
\hline
\end{tabular}




\section{Table C-1 (continued)}

\begin{tabular}{|c|c|c|c|c|c|c|c|c|c|c|c|c|}
\hline \multirow{3}{*}{ Metric } & \multicolumn{9}{|c|}{ Movement Towards the Quadrant } & \multirow{2}{*}{\multicolumn{3}{|c|}{$\begin{array}{l}\text { Present-day } \\
\text { Distance from } \\
\text { Quadrant }\end{array}$}} \\
\hline & \multicolumn{3}{|c|}{ Long -term (80-05) } & \multicolumn{3}{|c|}{ Med.-term (90-05) } & \multicolumn{3}{|c|}{ Short-term (00-05) } & & & \\
\hline & $\mathbf{n}$ & $\mathbf{R}$ & $P\left(H_{0}\right)$ & $\mathrm{n}$ & $\mathbf{R}$ & $\mathrm{P}\left(\mathrm{H}_{0}\right)$ & $\mathbf{n}$ & $\mathbf{R}$ & $\mathbf{P}\left(\mathrm{H}_{0}\right)$ & n & $\mathbf{R}$ & $\mathrm{P}\left(\mathrm{H}_{0}\right)$ \\
\hline $\begin{array}{l}\text { Children's Health: Infant mortality rate (deaths } \\
\text { per 1,000 live births) }\end{array}$ & 69 & $(0.251)$ & $<0.05$ & 83 & $(0.310)$ & $<0.01$ & 121 & $(0.314)$ & 0.001 & \multicolumn{3}{|c|}{$\begin{array}{l}\text { Not statistically } \\
\text { significant }\end{array}$} \\
\hline $\begin{array}{l}\text { Children's Health: Stunting in children under 5- } \\
\text {-moderate and severe (\%) }\end{array}$ & \multicolumn{3}{|c|}{ N/A } & \multicolumn{3}{|c|}{ N/A } & \multicolumn{3}{|c|}{ N/A } & 107 & $(0.579)$ & $<0.001$ \\
\hline $\begin{array}{l}\text { Children's Health: Under-5 mortality rate } \\
\text { (deaths per 1,000 live births) }\end{array}$ & 69 & $(0.254)$ & $<0.05$ & 83 & $(0.304)$ & $<0.01$ & 121 & $(0.295)$ & 0.001 & & $\begin{array}{l}\text { t statistic } \\
\text { significan }\end{array}$ & \\
\hline $\begin{array}{l}\text { Children's Health: Underweight children under } \\
\text { 5--moderate and severe (\%) }\end{array}$ & \multicolumn{3}{|c|}{ N/A } & \multicolumn{3}{|c|}{ N/A } & \multicolumn{3}{|c|}{ N/A } & 108 & $(0.569)$ & $<0.001$ \\
\hline $\begin{array}{l}\text { Children's Health: Wasting in children under } 5 \text { - } \\
\text {-moderate and severe (\%) }\end{array}$ & \multicolumn{3}{|c|}{ N/A } & \multicolumn{3}{|c|}{ N/A } & \multicolumn{3}{|c|}{ N/A } & 105 & $(0.529)$ & $<0.001$ \\
\hline $\begin{array}{l}\text { Civil Society: Density of international non- } \\
\text { governmental organizations with membership } \\
\text { (INGOs with membership per million } \\
\text { population) }\end{array}$ & \multicolumn{3}{|c|}{ N/A } & \multicolumn{3}{|c|}{$\begin{array}{l}\text { Not statistically } \\
\text { significant }\end{array}$} & 121 & $(0.337)$ & $<0.001$ & \multicolumn{3}{|c|}{$\begin{array}{l}\text { Not statistically } \\
\text { significant }\end{array}$} \\
\hline $\begin{array}{l}\text { CO2 Emissions per capita (metric tons per } \\
\text { capita) }\end{array}$ & 69 & $(0.234)$ & $<0.1$ & 82 & $(0.220)$ & $<0.05$ & 121 & $(0.165)$ & $<0.1$ & & $\begin{array}{l}\text { t statistic } \\
\text { significan }\end{array}$ & \\
\hline $\begin{array}{l}\text { Consumption of domestic water (internal } \\
\text { footprint) (m3/cap/year) }\end{array}$ & \multicolumn{3}{|c|}{ N/A } & \multicolumn{3}{|c|}{ N/A } & \multicolumn{3}{|c|}{ N/A } & 123 & 0.375 & $<0.001$ \\
\hline $\begin{array}{l}\text { Contraceptive Prevalence Rate (\% of married } \\
\text { women aged } 15-49 \text { practicing contraception) }\end{array}$ & \multicolumn{3}{|c|}{ N/A } & \multicolumn{3}{|c|}{ N/A } & \multicolumn{3}{|c|}{ N/A } & 87 & 0.686 & $<0.001$ \\
\hline
\end{tabular}


Table C-1 (continued)

\begin{tabular}{|c|c|c|c|c|c|c|c|c|c|c|c|c|}
\hline \multirow{3}{*}{ Metric } & \multicolumn{9}{|c|}{ Movement Towards the Quadrant } & \multirow{2}{*}{\multicolumn{3}{|c|}{$\begin{array}{c}\text { Present-day } \\
\text { Distance from } \\
\text { Quadrant }\end{array}$}} \\
\hline & \multicolumn{3}{|c|}{ Long -term (80-05) } & \multicolumn{3}{|c|}{ Med.-term (90-05) } & \multicolumn{3}{|c|}{ Short-term (00-05) } & & & \\
\hline & $\mathbf{n}$ & $\mathbf{R}$ & $\mathrm{P}\left(\mathrm{H}_{0}\right)$ & $\mathbf{n}$ & $\mathbf{R}$ & $\mathbf{P}\left(\mathrm{H}_{0}\right)$ & n & $\mathbf{R}$ & $\mathbf{P}\left(\mathbf{H}_{0}\right)$ & n & $\mathbf{R}$ & $P\left(H_{0}\right)$ \\
\hline $\begin{array}{l}\text { Corruption: Bribe Payer's Index (score from } 0 \\
\text { to } 10 \text {, with } 10 \text { being the "best") }\end{array}$ & \multicolumn{3}{|c|}{ N/A } & \multicolumn{3}{|c|}{ N/A } & \multicolumn{3}{|c|}{ N/A } & 29 & $(0.724)$ & $<0.001$ \\
\hline $\begin{array}{l}\text { Death rate from intestinal infectious diseases } \\
\text { (deaths per } 100,000 \text { population) }\end{array}$ & \multicolumn{3}{|c|}{ N/A } & \multicolumn{3}{|c|}{ N/A } & \multicolumn{3}{|c|}{ N/A } & 70 & 0.574 & $<0.001$ \\
\hline $\begin{array}{l}\text { Debt: Total debt service (current US\$ per } \\
\text { person) }\end{array}$ & \multicolumn{3}{|c|}{$\begin{array}{l}\text { Not statistically } \\
\text { significant }\end{array}$} & \multicolumn{3}{|c|}{$\begin{array}{l}\text { Not statistically } \\
\text { significant }\end{array}$} & 92 & $(0.284)$ & $<0.01$ & 109 & 0.641 & $<0.001$ \\
\hline $\begin{array}{l}\text { Demographics: Crude birth rate (births per } \\
\text { 1,000 people) }\end{array}$ & \multicolumn{3}{|c|}{$\begin{array}{l}\text { Not statistically } \\
\text { significant }\end{array}$} & \multicolumn{3}{|c|}{$\begin{array}{l}\text { Not statistically } \\
\text { significant }\end{array}$} & 121 & $(0.333)$ & $<0.001$ & 142 & $(0.275)$ & $<0.01$ \\
\hline $\begin{array}{l}\text { Demographics: Crude death rate (deaths per } \\
1,000 \text { people) }\end{array}$ & 69 & $(0.268)$ & $<0.05$ & 83 & $(0.339)$ & $<0.01$ & 121 & $(0.224)$ & $<0.05$ & 142 & $(0.482)$ & $<0.001$ \\
\hline $\begin{array}{l}\text { Demographics: Life expectancy at birth, both } \\
\text { sexes (years) }\end{array}$ & \multicolumn{3}{|c|}{$\begin{array}{l}\text { Not statistically } \\
\text { significant }\end{array}$} & 83 & 0.372 & $<0.001$ & 121 & 0.373 & $<0.001$ & \multicolumn{3}{|c|}{$\begin{array}{l}\text { Not statistically } \\
\text { significant }\end{array}$} \\
\hline $\begin{array}{l}\text { Demographics: Net number of migrants } \\
\text { (thousands of people) }\end{array}$ & 69 & $(0.375)$ & $<0.01$ & \multicolumn{3}{|c|}{$\begin{array}{l}\text { Not statistically } \\
\text { significant }\end{array}$} & \multicolumn{3}{|c|}{$\begin{array}{l}\text { Not statistically } \\
\text { significant }\end{array}$} & 142 & $(0.342)$ & $<0.001$ \\
\hline $\begin{array}{l}\text { Demographics: Total fertility rate (children per } \\
\text { woman) }\end{array}$ & \multicolumn{3}{|c|}{$\begin{array}{l}\text { Not statistically } \\
\text { significant }\end{array}$} & \multicolumn{3}{|c|}{$\begin{array}{l}\text { Not statistically } \\
\text { significant }\end{array}$} & 121 & $(0.364)$ & $<0.001$ & 142 & $(0.324)$ & $<0.001$ \\
\hline $\begin{array}{l}\text { Desertification Sub-Index (Standardized unit } \\
\text { scale - from 1-7; with } 1 \text { as good and } 7 \text { as bad) }\end{array}$ & \multicolumn{3}{|c|}{ N/A } & \multicolumn{3}{|c|}{ N/A } & \multicolumn{3}{|c|}{ N/A } & 142 & 0.342 & $<0.001$ \\
\hline $\begin{array}{l}\text { Development Assistance: (external) Aid as a } \\
\text { percent of government expenditure }\end{array}$ & \multicolumn{3}{|c|}{ N/A } & \multicolumn{3}{|c|}{$\begin{array}{l}\text { Not statistically } \\
\text { significant }\end{array}$} & \multicolumn{3}{|c|}{$\begin{array}{l}\text { Not statistically } \\
\text { significant }\end{array}$} & 48 & $(0.422)$ & $<0.001$ \\
\hline
\end{tabular}


Table C-1 (continued)

\begin{tabular}{|c|c|c|c|c|c|c|c|c|c|c|c|c|}
\hline \multirow{3}{*}{ Metric } & \multicolumn{9}{|c|}{ Movement Towards the Quadrant } & \multirow{2}{*}{\multicolumn{3}{|c|}{$\begin{array}{l}\text { Present-day } \\
\text { Distance from } \\
\text { Quadrant }\end{array}$}} \\
\hline & \multicolumn{3}{|c|}{ Long -term (80-05) } & \multicolumn{3}{|c|}{ Med.-term (90-05) } & \multicolumn{3}{|c|}{ Short-term (00-05) } & & & \\
\hline & $\mathbf{n}$ & $\mathbf{R}$ & $\mathrm{P}\left(\mathrm{H}_{0}\right)$ & $\mathbf{n}$ & $\mathbf{R}$ & $\mathbf{P}\left(\mathrm{H}_{0}\right)$ & $\mathbf{n}$ & $\mathbf{R}$ & $\mathbf{P}\left(\mathrm{H}_{0}\right)$ & n & $\mathbf{R}$ & $\mathbf{P}\left(\mathrm{H}_{0}\right)$ \\
\hline $\begin{array}{l}\text { Development Assistance: Aid received as a } \\
\text { percent of GNI }\end{array}$ & \multicolumn{3}{|c|}{$\begin{array}{l}\text { Not statistically } \\
\text { significant }\end{array}$} & \multicolumn{3}{|c|}{$\begin{array}{l}\text { Not statistically } \\
\text { significant }\end{array}$} & \multicolumn{3}{|c|}{$\begin{array}{l}\text { Not statistically } \\
\text { significant }\end{array}$} & 103 & $(0.660)$ & $<0.001$ \\
\hline $\begin{array}{l}\text { Dissolved oxygen concentration (mg. dissolved } \\
\text { oxygen per liter water) }\end{array}$ & \multicolumn{3}{|c|}{ N/A } & \multicolumn{3}{|c|}{ N/A } & \multicolumn{3}{|c|}{ N/A } & 49 & $(0.469)$ & $<0.001$ \\
\hline $\begin{array}{l}\text { EF: Built-up land footprint - \% of total } \\
\text { ecological footprint }\end{array}$ & 69 & 0.398 & $<0.001$ & 83 & 0.255 & $<0.05$ & 121 & 0.409 & $<0.001$ & \multicolumn{3}{|c|}{$\begin{array}{l}\text { Not statistically } \\
\text { significant }\end{array}$} \\
\hline $\begin{array}{l}\text { EF: Carbon footprint - \% of total ecological } \\
\text { footprint }\end{array}$ & 69 & $(0.338)$ & $<0.01$ & 83 & $(0.322)$ & $<0.01$ & 121 & $(0.303)$ & 0.001 & 142 & 0.209 & $<0.05$ \\
\hline $\begin{array}{l}\text { EF: Cropland footprint - \% of total ecological } \\
\text { footprint }\end{array}$ & 69 & 0.365 & $<0.01$ & \multicolumn{3}{|c|}{$\begin{array}{l}\text { Not statistically } \\
\text { significant }\end{array}$} & 121 & 0.318 & $<0.001$ & \multicolumn{3}{|c|}{$\begin{array}{l}\text { Not statistically } \\
\text { significant }\end{array}$} \\
\hline $\begin{array}{l}\text { EF: Grazing footprint - \% of total ecological } \\
\text { footprint }\end{array}$ & \multicolumn{3}{|c|}{$\begin{array}{l}\text { Not statistically } \\
\text { significant }\end{array}$} & 83 & 0.320 & $<0.01$ & 121 & 0.159 & $<0.1$ & \multicolumn{3}{|c|}{$\begin{array}{l}\text { Not statistically } \\
\text { significant }\end{array}$} \\
\hline $\begin{array}{l}\text { Education: Primary school net enrollment ratio } \\
(\%)\end{array}$ & \multicolumn{3}{|c|}{ N/A } & \multicolumn{3}{|c|}{ N/A } & 74 & 0.353 & $<0.01$ & \multicolumn{3}{|c|}{$\begin{array}{l}\text { Not statistically } \\
\text { significant }\end{array}$} \\
\hline $\begin{array}{l}\text { Education: Secondary school gender parity in } \\
\text { gross enrollment (Index value; } 100= \\
\text { enrollment equality) }\end{array}$ & \multicolumn{3}{|c|}{ N/A } & \multicolumn{3}{|c|}{ N/A } & 86 & 0.260 & $<0.05$ & 115 & 0.276 & $<0.01$ \\
\hline $\begin{array}{l}\text { Electricity consumption per capita (kWh per } \\
\text { person) }\end{array}$ & \multicolumn{3}{|c|}{ N/A } & 74 & $(0.226)$ & $<0.1$ & 105 & $(0.280)$ & $<0.01$ & \multicolumn{3}{|c|}{$\begin{array}{l}\text { Not statistically } \\
\text { significant }\end{array}$} \\
\hline $\begin{array}{l}\text { Energy Consumption by Source: Biogas and } \\
\text { liquid biomass (ktoe per million persons) }\end{array}$ & \multicolumn{3}{|c|}{ N/A } & 73 & $(0.210)$ & $<0.1$ & 103 & $(0.173)$ & $<0.1$ & 119 & $(0.433)$ & $<0.001$ \\
\hline
\end{tabular}


Table C-1 (continued)

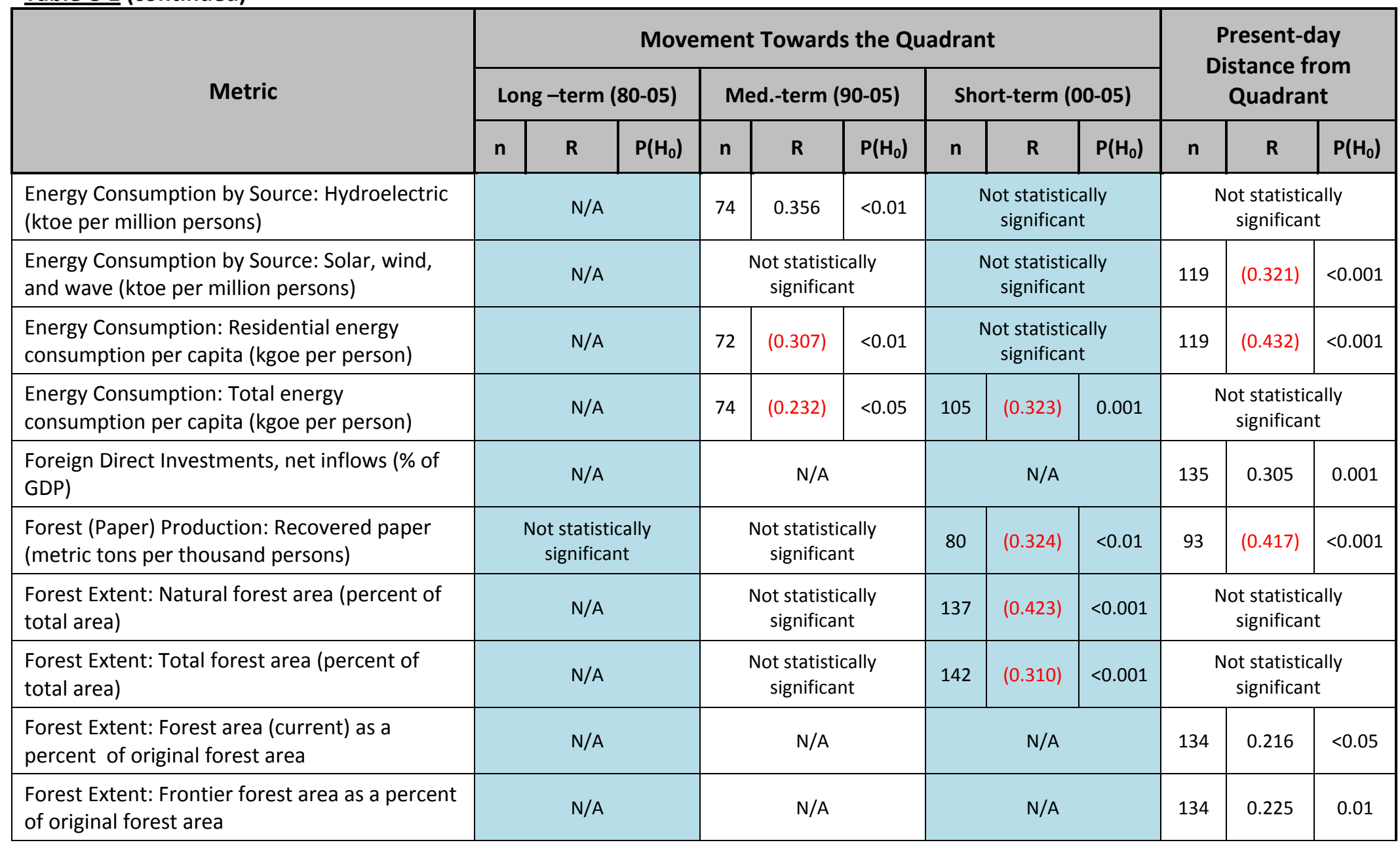


Table C-1 (continued)

\begin{tabular}{|c|c|c|c|c|c|c|c|c|c|c|c|c|}
\hline \multirow{3}{*}{ Metric } & \multicolumn{9}{|c|}{ Movement Towards the Quadrant } & \multirow{2}{*}{\multicolumn{3}{|c|}{$\begin{array}{l}\text { Present-day } \\
\text { Distance from } \\
\text { Quadrant }\end{array}$}} \\
\hline & \multicolumn{3}{|c|}{ Long -term (80-05) } & \multicolumn{3}{|c|}{ Med.-term (90-05) } & \multicolumn{3}{|c|}{ Short-term (00-05) } & & & \\
\hline & $\mathbf{n}$ & $\mathbf{R}$ & $\mathrm{P}\left(\mathrm{H}_{0}\right)$ & $\mathbf{n}$ & $\mathbf{R}$ & $P\left(H_{0}\right)$ & n & $\mathbf{R}$ & $\mathbf{P}\left(\mathbf{H}_{0}\right)$ & n & $\mathbf{R}$ & $P\left(H_{0}\right)$ \\
\hline GDP per capita, annual growth rate (\%) & \multicolumn{3}{|c|}{$\begin{array}{l}\text { Not statistically } \\
\text { significant }\end{array}$} & \multicolumn{3}{|c|}{$\begin{array}{l}\text { Not statistically } \\
\text { significant }\end{array}$} & \multicolumn{3}{|c|}{$\begin{array}{l}\text { Not statistically } \\
\text { significant }\end{array}$} & 140 & 0.325 & $<0.001$ \\
\hline $\begin{array}{l}\text { GDP per capita, PPP, current international } \\
\text { dollars }\end{array}$ & 69 & $(0.269)$ & $<0.05$ & \multicolumn{3}{|c|}{$\begin{array}{l}\text { Not statistically } \\
\text { significant }\end{array}$} & 121 & $(0.403)$ & $<0.001$ & \multicolumn{3}{|c|}{$\begin{array}{l}\text { Not statistically } \\
\text { significant }\end{array}$} \\
\hline $\begin{array}{l}\text { GDP: Official exchange rate (local currency / US } \\
\text { dollars) }\end{array}$ & 69 & 0.272 & $<0.05$ & \multicolumn{3}{|c|}{$\begin{array}{l}\text { Not statistically } \\
\text { significant }\end{array}$} & 120 & 0.310 & 0.001 & \multicolumn{3}{|c|}{$\begin{array}{l}\text { Not statistically } \\
\text { significant }\end{array}$} \\
\hline $\begin{array}{l}\text { Gender Empowerment Measure (GEM) (score, } \\
\text { from } 0 \text { to } 1 \text {, with } 1 \text { being the total gender } \\
\text { equality) }\end{array}$ & \multicolumn{3}{|c|}{ N/A } & \multicolumn{3}{|c|}{ N/A } & \multicolumn{3}{|c|}{ N/A } & 84 & $(0.458)$ & $<0.001$ \\
\hline $\begin{array}{l}\text { Investment in telecommunications (U.S. dollars } \\
\text { per person) }\end{array}$ & 23 & $(0.405)$ & $<0.1$ & \multicolumn{3}{|c|}{$\begin{array}{l}\text { Not statistically } \\
\text { significant }\end{array}$} & \multicolumn{3}{|c|}{$\begin{array}{l}\text { Not statistically } \\
\text { significant }\end{array}$} & \multicolumn{3}{|c|}{$\begin{array}{l}\text { Not statistically } \\
\text { significant }\end{array}$} \\
\hline $\begin{array}{l}\text { Irrigated land as a percent of total agricultural } \\
\text { area (\%) }\end{array}$ & \multicolumn{3}{|c|}{$\begin{array}{l}\text { Not statistically } \\
\text { significant }\end{array}$} & \multicolumn{3}{|c|}{$\begin{array}{l}\text { Not statistically } \\
\text { significant }\end{array}$} & \multicolumn{3}{|c|}{$\begin{array}{l}\text { Not statistically } \\
\text { significant }\end{array}$} & 137 & 0.348 & $<0.001$ \\
\hline $\begin{array}{l}\text { Labor: Workers' remittances and } \\
\text { compensation of employees, received (million } \\
\text { US\$ per capita) }\end{array}$ & \multicolumn{3}{|c|}{$\begin{array}{l}\text { Not statistically } \\
\text { significant }\end{array}$} & 62 & 0.236 & $<0.1$ & 107 & (0.199) & $<0.05$ & 128 & 0.283 & $<0.001$ \\
\hline $\begin{array}{l}\text { Land Degradation (\% of a country's land area } \\
\text { considered severely and very severely } \\
\text { degraded) }\end{array}$ & \multicolumn{3}{|c|}{ N/A } & \multicolumn{3}{|c|}{ N/A } & \multicolumn{3}{|c|}{ N/A } & 139 & 0.382 & $<0.001$ \\
\hline $\begin{array}{l}\text { Language Fractionalization Index } \\
\text { (fractionalization score: higher means more } \\
\text { diverse) }\end{array}$ & \multicolumn{3}{|c|}{ N/A } & \multicolumn{3}{|c|}{ N/A } & \multicolumn{3}{|c|}{ N/A } & 137 & $(0.351)$ & $<0.001$ \\
\hline
\end{tabular}


Table C-1 (continued)

\begin{tabular}{|c|c|c|c|c|c|c|c|c|c|c|c|c|}
\hline \multirow{3}{*}{ Metric } & \multicolumn{9}{|c|}{ Movement Towards the Quadrant } & \multirow{2}{*}{\multicolumn{3}{|c|}{$\begin{array}{l}\text { Present-day } \\
\text { Distance from } \\
\text { Quadrant }\end{array}$}} \\
\hline & \multicolumn{3}{|c|}{ Long -term (80-05) } & \multicolumn{3}{|c|}{ Med.-term (90-05) } & \multicolumn{3}{|c|}{ Short-term (00-05) } & & & \\
\hline & $\mathbf{n}$ & $\mathbf{R}$ & $\mathrm{P}\left(\mathrm{H}_{0}\right)$ & $\mathrm{n}$ & $\mathbf{R}$ & $\mathrm{P}\left(\mathrm{H}_{0}\right)$ & $\mathbf{n}$ & $\mathbf{R}$ & $\mathrm{P}\left(\mathrm{H}_{0}\right)$ & $\mathrm{n}$ & $\mathbf{R}$ & $\mathrm{P}\left(\mathrm{H}_{0}\right)$ \\
\hline $\begin{array}{l}\text { Literacy: Female literacy rate as a percentage } \\
\text { of male literacy rate (\%) }\end{array}$ & \multicolumn{3}{|c|}{ N/A } & \multicolumn{3}{|c|}{ N/A } & \multicolumn{3}{|c|}{ N/A } & 97 & 0.552 & $<0.001$ \\
\hline Literacy: Literacy rate, all adults (\%) & \multicolumn{3}{|c|}{ N/A } & \multicolumn{3}{|c|}{ N/A } & \multicolumn{3}{|c|}{ N/A } & 97 & 0.550 & $<0.001$ \\
\hline Literacy: Literacy rate, youth (age 15 to 24 ) (\%) & \multicolumn{3}{|c|}{ N/A } & \multicolumn{3}{|c|}{ N/A } & \multicolumn{3}{|c|}{ N/A } & 93 & 0.549 & $<0.001$ \\
\hline Livestock: Goat stocks (8head per person) & \multicolumn{3}{|c|}{$\begin{array}{l}\text { Not statistically } \\
\text { significant }\end{array}$} & 71 & 0.315 & $<0.01$ & \multicolumn{3}{|c|}{$\begin{array}{l}\text { Not statistically } \\
\text { significant }\end{array}$} & \multicolumn{3}{|c|}{$\begin{array}{l}\text { Not statistically } \\
\text { significant }\end{array}$} \\
\hline $\begin{array}{l}\text { Local Air Quality Score (unitless scale - } 0 \text { is the } \\
\text { worst possible score and } 100 \text { is the best) }\end{array}$ & \multicolumn{3}{|c|}{ N/A } & \multicolumn{3}{|c|}{ N/A } & \multicolumn{3}{|c|}{ N/A } & 51 & $(0.494)$ & $<0.001$ \\
\hline Long term unemployment (\% of labor force) & \multicolumn{3}{|c|}{$\mathrm{N} / \mathrm{A}$} & \multicolumn{3}{|c|}{ N/A } & \multicolumn{3}{|c|}{ N/A } & 27 & 0.535 & $<0.01$ \\
\hline Meat Consumption: Per capita (Kg. per person) & 67 & $(0.401)$ & $<0.001$ & 80 & $(0.298)$ & $<0.01$ & 119 & $(0.278)$ & $<0.01$ & & $\begin{array}{l}\text { t statisti } \\
\text { significar }\end{array}$ & \\
\hline $\begin{array}{l}\text { Micro, Small, and Medium Enterprises: MSMEs } \\
\text { per } 1000 \text { people }\end{array}$ & \multicolumn{3}{|c|}{ N/A } & \multicolumn{3}{|c|}{ N/A } & \multicolumn{3}{|c|}{ N/A } & 85 & $(0.407)$ & $<0.001$ \\
\hline $\begin{array}{l}\text { NBI (National Biodiversity Index) (score } \\
\text { between } 0 \text { and } 1 \text { with large values } \\
\text { corresponding to high levels of species } \\
\text { abundance and small values reflecting low } \\
\text { levels of species abundance) }\end{array}$ & \multicolumn{3}{|c|}{ N/A } & \multicolumn{3}{|c|}{ N/A } & \multicolumn{3}{|c|}{ N/A } & 140 & 0.238 & $<0.01$ \\
\hline
\end{tabular}


Table C-1 (continued)

\begin{tabular}{|c|c|c|c|c|c|c|c|c|c|c|c|c|}
\hline \multirow{3}{*}{ Metric } & \multicolumn{9}{|c|}{ Movement Towards the Quadrant } & \multirow{2}{*}{\multicolumn{3}{|c|}{$\begin{array}{c}\text { Present-day } \\
\text { Distance from } \\
\text { Quadrant }\end{array}$}} \\
\hline & \multicolumn{3}{|c|}{ Long -term (80-05) } & \multicolumn{3}{|c|}{ Med.-term (90-05) } & \multicolumn{3}{|c|}{ Short-term (00-05) } & & & \\
\hline & $\mathbf{n}$ & $\mathbf{R}$ & $\mathbf{P}\left(\mathbf{H}_{0}\right)$ & $\mathbf{n}$ & $\mathbf{R}$ & $P\left(H_{0}\right)$ & $\mathbf{n}$ & $\mathbf{R}$ & $\mathbf{P}\left(\mathrm{H}_{0}\right)$ & $\mathbf{n}$ & $\mathbf{R}$ & $\mathbf{P}\left(\mathrm{H}_{0}\right)$ \\
\hline $\begin{array}{l}\text { Number of researchers in R\&D per million } \\
\text { inhabitants }\end{array}$ & \multicolumn{3}{|c|}{ N/A } & \multicolumn{3}{|c|}{ N/A } & \multicolumn{3}{|c|}{ N/A } & 78 & $(0.414)$ & $<0.001$ \\
\hline $\begin{array}{l}\text { Nutrition: Calorie supply per capita from } \\
\text { animal products (kilocalories/person/day) }\end{array}$ & 68 & $(0.323)$ & $<0.01$ & \multicolumn{3}{|c|}{$\begin{array}{l}\text { Not statistically } \\
\text { significant }\end{array}$} & 120 & $(0.223)$ & $<0.05$ & \multicolumn{3}{|c|}{$\begin{array}{l}\text { Not statistically } \\
\text { significant }\end{array}$} \\
\hline $\begin{array}{l}\text { Nutrition: Grain fed to livestock as a percent of } \\
\text { total grain consumed (\%) }\end{array}$ & \multicolumn{3}{|c|}{$\begin{array}{l}\text { Not statistically } \\
\text { significant }\end{array}$} & \multicolumn{3}{|c|}{$\begin{array}{l}\text { Not statistically } \\
\text { significant }\end{array}$} & \multicolumn{3}{|c|}{$\begin{array}{l}\text { Not statistically } \\
\text { significant }\end{array}$} & 74 & 0.429 & $<0.001$ \\
\hline $\begin{array}{l}\text { Official development asst. received (net } \\
\text { disbursements) (\% of GDP) }\end{array}$ & \multicolumn{3}{|c|}{ N/A } & \multicolumn{3}{|c|}{ N/A } & \multicolumn{3}{|c|}{ N/A } & 96 & $(0.654)$ & $<0.001$ \\
\hline $\begin{array}{l}\text { Organic Farming: Organic land area as a } \\
\text { percent of total agricultural area }\end{array}$ & \multicolumn{3}{|c|}{ N/A } & \multicolumn{3}{|c|}{ N/A } & \multicolumn{3}{|c|}{ N/A } & 94 & $(0.360)$ & $<0.001$ \\
\hline $\begin{array}{l}\text { Other Greenhouse Gases per capita (metric } \\
\text { tons per capita) }\end{array}$ & \multicolumn{3}{|c|}{ N/A } & \multicolumn{3}{|c|}{ N/A } & \multicolumn{3}{|c|}{ N/A } & 32 & $(0.367)$ & $<0.05$ \\
\hline $\begin{array}{l}\text { Patents granted to residents (\# of patents per } \\
\text { million people) }\end{array}$ & \multicolumn{3}{|c|}{ N/A } & \multicolumn{3}{|c|}{ N/A } & \multicolumn{3}{|c|}{ N/A } & 71 & $(0.457)$ & $<0.001$ \\
\hline Percent GDP from industry & \multicolumn{3}{|c|}{$\begin{array}{l}\text { Not statistically } \\
\text { significant }\end{array}$} & \multicolumn{3}{|c|}{$\begin{array}{l}\text { Not statistically } \\
\text { significant }\end{array}$} & \multicolumn{3}{|c|}{$\begin{array}{l}\text { Not statistically } \\
\text { significant }\end{array}$} & 129 & 0.358 & $<0.001$ \\
\hline Percent GDP from manufacturing & \multicolumn{3}{|c|}{$\begin{array}{l}\text { Not statistically } \\
\text { significant }\end{array}$} & \multicolumn{3}{|c|}{$\begin{array}{l}\text { Not statistically } \\
\text { significant }\end{array}$} & \multicolumn{3}{|c|}{$\begin{array}{l}\text { Not statistically } \\
\text { significant }\end{array}$} & 123 & 0.300 & 0.001 \\
\hline $\begin{array}{l}\text { Percentage of the population with insufficient } \\
\text { food }\end{array}$ & \multicolumn{3}{|c|}{ N/A } & \multicolumn{3}{|c|}{ N/A } & \multicolumn{3}{|c|}{ N/A } & 89 & $(0.567)$ & $<0.001$ \\
\hline
\end{tabular}


Table C-1 (continued)

\begin{tabular}{|c|c|c|c|c|c|c|c|c|c|c|}
\hline \multirow{3}{*}{ Metric } & \multicolumn{7}{|c|}{ Movement Towards the Quadrant } & \multirow{2}{*}{\multicolumn{3}{|c|}{$\begin{array}{l}\text { Present-day } \\
\text { Distance from } \\
\text { Quadrant }\end{array}$}} \\
\hline & \multicolumn{2}{|c|}{ Long -term (80-05) } & \multicolumn{2}{|c|}{ Med.-term (90-05) } & \multicolumn{3}{|c|}{ Short-term (00-05) } & & & \\
\hline & $\mathbf{n}$ & $\mathbf{P}\left(\mathbf{H}_{0}\right)$ & n & $\mathbf{P}\left(\mathbf{H}_{0}\right)$ & $\mathbf{n}$ & $\mathbf{R}$ & $\mathbf{P}\left(\mathbf{H}_{0}\right)$ & $\mathbf{n}$ & $\mathbf{R}$ & $\mathbf{P}\left(\mathrm{H}_{0}\right)$ \\
\hline $\begin{array}{l}\text { Pesticide use (Kg. pesticides used per year per } \\
\mathrm{km}^{2} \text { of total land area) }\end{array}$ & \multicolumn{2}{|r|}{ N/A } & \multicolumn{2}{|r|}{ N/A } & \multicolumn{3}{|c|}{ N/A } & 92 & 0.383 & $<0.001$ \\
\hline $\begin{array}{l}\text { Politics and Freedom: Regulatory Quality Index } \\
\text { (Index: }-2.5 \text { worst governance, } 0 \text { average, } 2.5 \\
\text { best governance) }\end{array}$ & \multicolumn{2}{|r|}{ N/A } & \multicolumn{2}{|r|}{ N/A } & 121 & (0.306) & 0.001 & \multicolumn{3}{|c|}{$\begin{array}{l}\text { Not statistically } \\
\text { significant }\end{array}$} \\
\hline Population density (people per square $\mathrm{km}^{2}$ ) & \multicolumn{2}{|r|}{$\begin{array}{l}\text { Not statistically } \\
\text { significant }\end{array}$} & \multicolumn{2}{|r|}{$\begin{array}{l}\text { Not statistically } \\
\text { significant }\end{array}$} & 119 & 0.339 & $<0.001$ & \multicolumn{3}{|c|}{$\begin{array}{l}\text { Not statistically } \\
\text { significant }\end{array}$} \\
\hline $\begin{array}{l}\text { Population using improved sanitation (\% of the } \\
\text { population) }\end{array}$ & \multicolumn{2}{|r|}{ N/A } & \multicolumn{2}{|r|}{ N/A } & \multicolumn{3}{|c|}{ N/A } & 120 & 0.339 & $<0.001$ \\
\hline $\begin{array}{l}\text { Population without electricity (\% of the } \\
\text { population) }\end{array}$ & \multicolumn{2}{|r|}{ N/A } & \multicolumn{2}{|r|}{ N/A } & \multicolumn{3}{|c|}{ N/A } & 77 & $(0.657)$ & $<0.001$ \\
\hline $\begin{array}{l}\text { Population: Above age } 65 \text {, both sexes ( } \% \text { of the } \\
\text { population) }\end{array}$ & \multicolumn{2}{|r|}{$\begin{array}{l}\text { Not statistically } \\
\text { significant }\end{array}$} & \multicolumn{2}{|r|}{$\begin{array}{l}\text { Not statistically } \\
\text { significant }\end{array}$} & 121 & $(0.205)$ & $<0.05$ & 142 & 0.232 & $<0.01$ \\
\hline $\begin{array}{l}\text { Population: Below age } 15 \text {, both sexes (\% of the } \\
\text { population) }\end{array}$ & \multicolumn{2}{|r|}{$\begin{array}{l}\text { Not statistically } \\
\text { significant }\end{array}$} & \multicolumn{2}{|r|}{$\begin{array}{l}\text { Not statistically } \\
\text { significant }\end{array}$} & 121 & 0.257 & $<0.01$ & \multicolumn{3}{|c|}{$\begin{array}{l}\text { Not statistically } \\
\text { significant }\end{array}$} \\
\hline $\begin{array}{l}\text { Population: Growth rate of total population } \\
\text { (\%) }\end{array}$ & \multicolumn{2}{|r|}{$\begin{array}{l}\text { Not statistically } \\
\text { significant }\end{array}$} & \multicolumn{2}{|r|}{$\begin{array}{l}\text { Not statistically } \\
\text { significant }\end{array}$} & \multicolumn{3}{|c|}{$\begin{array}{l}\text { Not statistically } \\
\text { significant }\end{array}$} & 142 & $(0.326)$ & $<0.001$ \\
\hline $\begin{array}{l}\text { Poverty: National poverty rates (\% of national } \\
\text { population) }\end{array}$ & \multicolumn{2}{|r|}{ N/A } & \multicolumn{2}{|r|}{ N/A } & \multicolumn{3}{|c|}{ N/A } & 89 & $(0.468)$ & $<0.001$ \\
\hline $\begin{array}{l}\text { Public Health: Contraceptive prevalence rate } \\
\text { (percent of married women age 15-49) }\end{array}$ & \multicolumn{2}{|r|}{ N/A } & \multicolumn{2}{|r|}{ N/A } & \multicolumn{3}{|c|}{ N/A } & 129 & 0.381 & $<0.001$ \\
\hline
\end{tabular}


Table C-1 (continued)

\begin{tabular}{|c|c|c|c|c|c|c|c|c|c|c|c|}
\hline \multirow{3}{*}{ Metric } & \multicolumn{8}{|c|}{ Movement Towards the Quadrant } & \multirow{2}{*}{\multicolumn{3}{|c|}{$\begin{array}{l}\text { Present-day } \\
\text { Distance from } \\
\text { Quadrant }\end{array}$}} \\
\hline & \multicolumn{2}{|c|}{ Long -term (80-05) } & \multicolumn{3}{|c|}{ Med.-term (90-05) } & \multicolumn{3}{|c|}{ Short-term (00-05) } & & & \\
\hline & $\mathbf{n}$ & $\mathrm{P}\left(\mathrm{H}_{0}\right)$ & $\mathrm{n}$ & $\mathbf{R}$ & $\mathrm{P}\left(\mathrm{H}_{0}\right)$ & $\mathbf{n}$ & $\mathbf{R}$ & $\mathrm{P}\left(\mathrm{H}_{0}\right)$ & $\mathbf{n}$ & $\mathbf{R}$ & $\mathbf{P}\left(\mathbf{H}_{0}\right)$ \\
\hline $\begin{array}{l}\text { Public Health: Per capita total expenditure on } \\
\text { health (international dollars per person) }\end{array}$ & \multicolumn{2}{|r|}{ N/A } & \multicolumn{3}{|c|}{ N/A } & 121 & $(0.356)$ & $<0.001$ & \multicolumn{3}{|c|}{$\begin{array}{l}\text { Not statistically } \\
\text { significant }\end{array}$} \\
\hline Public Health: Solid fuel use (\%) & \multicolumn{2}{|r|}{ N/A } & \multicolumn{3}{|c|}{ N/A } & \multicolumn{3}{|c|}{ N/A } & 141 & $(0.335)$ & $<0.001$ \\
\hline $\begin{array}{l}\text { Religious Fractionalization Index } \\
\text { (fractionalization score: higher means more } \\
\text { diverse) }\end{array}$ & \multicolumn{2}{|r|}{ N/A } & \multicolumn{3}{|c|}{ N/A } & \multicolumn{3}{|c|}{ N/A } & 141 & $(0.255)$ & $<0.01$ \\
\hline $\begin{array}{l}\text { Religious freedom index (Units: 1-3=Free; } 4- \\
\text { 5=Partly free; 6-7=Not free) }\end{array}$ & \multicolumn{2}{|r|}{ N/A } & \multicolumn{3}{|c|}{ N/A } & \multicolumn{3}{|c|}{ N/A } & 70 & 0.401 & $<0.001$ \\
\hline $\begin{array}{l}\text { Research and Development expenditure (\% of } \\
\text { GDP) }\end{array}$ & \multicolumn{2}{|r|}{ N/A } & \multicolumn{3}{|c|}{ N/A } & \multicolumn{3}{|c|}{ N/A } & 92 & $(0.433)$ & $<0.001$ \\
\hline Suspended solids per liter water (mg.) & \multicolumn{2}{|r|}{ N/A } & \multicolumn{3}{|c|}{ N/A } & \multicolumn{3}{|c|}{ N/A } & 27 & 0.439 & $<0.05$ \\
\hline Total external debt (current US\$ per person) & \multicolumn{2}{|r|}{$\begin{array}{l}\text { Not statistically } \\
\text { significant }\end{array}$} & \multicolumn{3}{|c|}{$\begin{array}{l}\text { Not statistically } \\
\text { significant }\end{array}$} & 92 & $(0.339)$ & 0.001 & 109 & 0.570 & $<0.001$ \\
\hline $\begin{array}{l}\text { Total fertility Rate (average number of births } \\
\text { per woman based on current age-specific } \\
\text { fertility rates) }\end{array}$ & \multicolumn{2}{|r|}{ N/A } & \multicolumn{3}{|c|}{ N/A } & \multicolumn{3}{|c|}{$\mathrm{N} / \mathrm{A}$} & 142 & $(0.335)$ & $<0.001$ \\
\hline $\begin{array}{l}\text { Trade in Forest Products: Imports, value (US } \\
\text { dollars per person) }\end{array}$ & \multicolumn{2}{|r|}{$\begin{array}{l}\text { Not statistically } \\
\text { significant }\end{array}$} & \multicolumn{3}{|c|}{$\begin{array}{l}\text { Not statistically } \\
\text { significant }\end{array}$} & 120 & $(0.323)$ & $<0.001$ & \multicolumn{3}{|c|}{$\begin{array}{l}\text { Not statistically } \\
\text { significant }\end{array}$} \\
\hline $\begin{array}{l}\text { Transportation: Motor gasoline consumption } \\
\text { per capita (Liters per person) }\end{array}$ & \multicolumn{2}{|r|}{$\mathrm{N} / \mathrm{A}$} & 73 & $(0.294)$ & $<0.05$ & 103 & $(0.211)$ & $<0.05$ & \multicolumn{3}{|c|}{$\begin{array}{l}\text { Not statistically } \\
\text { significant }\end{array}$} \\
\hline
\end{tabular}


Table C-1 (continued)

\begin{tabular}{|c|c|c|c|c|c|c|c|c|c|c|c|c|}
\hline \multirow{3}{*}{ Metric } & \multicolumn{9}{|c|}{ Movement Towards the Quadrant } & \multirow{2}{*}{\multicolumn{3}{|c|}{$\begin{array}{l}\text { Present-day } \\
\text { Distance from } \\
\text { Quadrant }\end{array}$}} \\
\hline & \multicolumn{3}{|c|}{ Long -term (80-05) } & \multicolumn{3}{|c|}{ Med.-term (90-05) } & \multicolumn{3}{|c|}{ Short-term (00-05) } & & & \\
\hline & $\mathbf{n}$ & $\mathbf{R}$ & $P\left(H_{0}\right)$ & $\mathbf{n}$ & $\mathbf{R}$ & $P\left(H_{0}\right)$ & $\mathbf{n}$ & $\mathbf{R}$ & $\mathbf{P}\left(\mathbf{H}_{0}\right)$ & $\mathbf{n}$ & $\mathbf{R}$ & $\mathbf{P}\left(\mathrm{H}_{0}\right)$ \\
\hline $\begin{array}{l}\text { Transportation: Passenger cars per } 1000 \\
\text { people }\end{array}$ & \multicolumn{3}{|c|}{$\begin{array}{l}\text { Not statistically } \\
\text { significant }\end{array}$} & \multicolumn{3}{|c|}{$\begin{array}{l}\text { Not statistically } \\
\text { significant }\end{array}$} & \multicolumn{3}{|c|}{$\begin{array}{l}\text { Not statistically } \\
\text { significant }\end{array}$} & 48 & $(0.547)$ & $<0.001$ \\
\hline $\begin{array}{l}\text { Transportation: Pump prices for diesel fuel (US } \\
\text { dollars per liter) }\end{array}$ & \multicolumn{3}{|c|}{ N/A } & \multicolumn{3}{|c|}{ N/A } & \multicolumn{3}{|c|}{ N/A } & 139 & $(0.393)$ & $<0.001$ \\
\hline $\begin{array}{l}\text { Transportation: Volume of public road } \\
\text { transport (passenger-km per person) }\end{array}$ & \multicolumn{3}{|c|}{ N/A } & \multicolumn{3}{|c|}{ N/A } & \multicolumn{3}{|c|}{ N/A } & 21 & (0.541) & $<0.05$ \\
\hline $\begin{array}{l}\text { Urban and Rural Areas: Growth rate of rural } \\
\text { population (\%) }\end{array}$ & \multicolumn{3}{|c|}{$\begin{array}{l}\text { Not statistically } \\
\text { significant }\end{array}$} & 83 & 0.262 & $<0.05$ & \multicolumn{3}{|c|}{$\begin{array}{l}\text { Not statistically } \\
\text { significant }\end{array}$} & 142 & $(0.337)$ & $<0.001$ \\
\hline $\begin{array}{l}\text { Urban and Rural Areas: Total population in } \\
\text { cities with more than } 100,000 \text { inhabitants (\% } \\
\text { of population in 2000) }\end{array}$ & \multicolumn{3}{|c|}{ N/A } & \multicolumn{3}{|c|}{ N/A } & \multicolumn{3}{|c|}{ N/A } & 119 & 0.408 & $<0.001$ \\
\hline $\begin{array}{l}\text { Urban and Rural Areas: Urban population as a } \\
\text { percent of total population (\%) }\end{array}$ & \multicolumn{3}{|c|}{$\begin{array}{l}\text { Not statistically } \\
\text { significant }\end{array}$} & \multicolumn{3}{|c|}{$\begin{array}{l}\text { Not statistically } \\
\text { significant }\end{array}$} & 121 & 0.168 & $<0.1$ & \multicolumn{3}{|c|}{$\begin{array}{l}\text { Not statistically } \\
\text { significant }\end{array}$} \\
\hline $\begin{array}{l}\text { Urban population weighted TSP concentration } \\
\text { (micrograms TSP per } \mathrm{m}^{3} \text { ) }\end{array}$ & \multicolumn{3}{|c|}{ N/A } & \multicolumn{3}{|c|}{ N/A } & \multicolumn{3}{|c|}{ N/A } & 60 & 0.402 & $<0.01$ \\
\hline
\end{tabular}

$\mathrm{n}=$ number of pairs of data (countries).

$\mathrm{R}=$ Pearson moment correlation coefficient.

$\mathrm{P}\left(\mathrm{H}_{0}\right)=$ Probability for the Null Hypothesis (i.e., no correlation).

See Appendix D for a list of complete definitions and original sources of these statistically significant metrics. 


\section{Appendix D: Definitions and Original Sources for Statistically Significant Metrics Found in the Analysis}

\section{Table D-1: Definitions and Sources for Statistically Significant Metrics Found in the Analysis}

Source: Compiled by the author.

\begin{tabular}{|c|c|c|}
\hline Metric & Definition & Original Source \\
\hline $\begin{array}{l}\text { Access to Information: } \\
\text { Cellular mobile } \\
\text { telephone subscribers } \\
\text { per } 1000 \text { people }\end{array}$ & $\begin{array}{l}\text { Cellular mobile telephone subscribers per } 1000 \text { people refers } \\
\text { to the proportion of the population that subscribe to an } \\
\text { automatic public mobile telephone service for portable } \\
\text { telephones. Subscribers to public mobile data services, private } \\
\text { trunked mobile radio, telepoint, or radio paging services are } \\
\text { not included. Quoted from the Earth Trends portal.. }\end{array}$ & $\begin{array}{l}\text { International Telecommunication Union } \\
\text { (ITU). 2007. World Telecommunication } \\
\text { Indicators 2006. Geneva: ITU. Available } \\
\text { online at http://www.itu.int/ITU- } \\
\text { D/ict/publications/world/world.html. }\end{array}$ \\
\hline $\begin{array}{l}\text { Access to Information: } \\
\text { Homes with personal } \\
\text { computers (\% of } \\
\text { homes) }\end{array}$ & $\begin{array}{l}\text { Homes with personal computers is the percentage of } \\
\text { households with one or more personal computers. Quoted } \\
\text { from the Earth Trends portal. }\end{array}$ & $\begin{array}{l}\text { International Telecommunication Union } \\
\text { (ITU). 2006. World Telecommunication } \\
\text { Indicators 2005. Geneva: ITU. Available } \\
\text { online at http://www.itu.int/ITU- } \\
\text { D/ict/publications/world/world.html. }\end{array}$ \\
\hline $\begin{array}{l}\text { Access to Information: } \\
\text { Homes with } \\
\text { telephones (\% of } \\
\text { homes) }\end{array}$ & $\begin{array}{l}\text { Homes with telephones is the percentage of households with } \\
\text { one or more private telephone lines. }\end{array}$ & $\begin{array}{l}\text { International Telecommunication Union } \\
\text { (ITU). 2006. World Telecommunication } \\
\text { Indicators 2005. Geneva: ITU. Available } \\
\text { online at http://www.itu.int/ITU- } \\
\text { D/ict/publications/world/world.html. }\end{array}$ \\
\hline $\begin{array}{l}\text { Access to Information: } \\
\text { Internet users per } \\
1000 \text { people }\end{array}$ & $\begin{array}{l}\text { Internet users per } 1000 \text { people refers to the proportion of a } \\
\text { country's population that have used the internet at any point } \\
\text { in time during the specified year. Quoted from the Earth } \\
\text { Trends portal. }\end{array}$ & $\begin{array}{l}\text { International Telecommunication Union } \\
\text { (ITU). 2007. World Telecommunication } \\
\text { Indicators 2006. Geneva: ITU. Available } \\
\text { online at http://www.itu.int/ITU- } \\
\text { D/ict/publications/world/world.html. }\end{array}$ \\
\hline $\begin{array}{l}\text { Adequate solid waste } \\
\text { disposal (\% of total } \\
\text { waste disposal) }\end{array}$ & Adequate solid waste disposal as a \% of total waste disposal. & UN-Habitat database \\
\hline
\end{tabular}


Table D-1 (continued)

\begin{tabular}{|c|c|c|}
\hline Metric & Definition & Original Source \\
\hline $\begin{array}{l}\text { Adult literacy rate (\% } \\
\text { aged } 15 \text { or older) }\end{array}$ & Adult literacy rate (\% aged 15 or older) & $\begin{array}{l}\text { UNESCO (United Nations Educational, } \\
\text { Scientific and Cultural Organization) } \\
\text { Institute for Statistics. 2007a. } \\
\text { Correspondence on adult and youth } \\
\text { literacy rates. May. Montreal. }\end{array}$ \\
\hline $\begin{array}{l}\text { Agricultural Inputs: } \\
\text { Water use intensity } \\
\left(\mathrm{m}^{3} / \mathrm{ha} / \mathrm{yr}\right)\end{array}$ & $\begin{array}{l}\text { Water use intensity is the amount of water used in the } \\
\text { agricultural sector per hectare of temporary and permanent } \\
\text { cropland in the year specified. This indicator shows a country's } \\
\text { dependence on irrigation for agricultural production. Data are } \\
\text { given in cubic meters per hectare per year. Quoted from the } \\
\text { Earth Trends portal. }\end{array}$ & $\begin{array}{l}\text { Food and Agriculture Organization of the } \\
\text { United Nations (FAO) Land and Water } \\
\text { Development Division. 2007. AQUASTAT } \\
\text { Information System on Water and } \\
\text { Agriculture: Online database. Rome: FAO. } \\
\text { And: Food and Agriculture Organization of } \\
\text { the United Nations (FAO). 2008. FAOSTAT } \\
\text { Online Statistical Service. Rome: FAO. }\end{array}$ \\
\hline $\begin{array}{l}\text { Agricultural } \\
\text { Production Indices: } \\
\text { Food production per } \\
\text { capita index (\% of } \\
1999-2001 \text { avg. food } \\
\text { production per capita) }\end{array}$ & $\begin{array}{l}\text { The food production per capita index presents net food } \\
\text { production (after deduction for feed and seed) of a country's } \\
\text { agricultural sector per person relative to the base period 1999- } \\
\text { 2001. The food production per capita index covers all edible } \\
\text { agricultural products that contain nutrients; coffee and tea are } \\
\text { excluded. Quoted from the Earth Trends portal. }\end{array}$ & $\begin{array}{l}\text { Food and Agriculture Organization of the } \\
\text { United Nations (FAO). 2006. FAOSTAT } \\
\text { Online Statistical Service. Rome: FAO. } \\
\text { Available online at: http://apps.fao.org. }\end{array}$ \\
\hline
\end{tabular}


Table D-1 (continued)

\begin{tabular}{|c|c|c|}
\hline Metric & Definition & Original Source \\
\hline $\begin{array}{l}\text { Base of the Pyramid: } \\
\text { Share of total } \\
\text { household } \\
\text { expenditure, } \\
\text { information and } \\
\text { communication } \\
\text { technology (\% of total } \\
\text { household } \\
\text { expenditure among } \\
\text { those earning less } \\
\text { than } \$ 3,000 \text { annually) }\end{array}$ & $\begin{array}{l}\text { Share of total household expenditure, information and } \\
\text { communication technology (ICT) refers to the proportion of } \\
\text { household spending that is dedicated to ICT among those } \\
\text { earning less than } \$ 3,000 \text { per year (the Base of the Pyramid). } \\
\text { ICT includes telephone and telefax equipment and services } \\
\text { and audio-visual, photographic and information processing } \\
\text { equipment. Income cutoffs are given in } 2002 \text { international } \\
\text { dollars, adjusted for purchasing power parity (PPP); when } \\
\text { inflated to } 2005 \text { international dollars, the actual income cutoff } \\
\text { is } \$ 3,260 \text {. The aim of this data is to generate poverty-specific } \\
\text { purchasing power parities that take into account the spending } \\
\text { patterns of the poor. Quoted from the Earth Trends portal. }\end{array}$ & $\begin{array}{l}\text { World Resources Institute (WRI) and the } \\
\text { International Finance Corporation (IFC), } \\
\text { 2007. Next Four Billion: Market Size \& } \\
\text { Business Strategy at the Base of the } \\
\text { Pyramid. Washington, D.C.: WRI. Available } \\
\text { on-line at: } \\
\text { http://www.nextbillion.net/thenext4billio } \\
\mathrm{n} \text { and http://www.wri.org/thenext4billion. }\end{array}$ \\
\hline $\begin{array}{l}\text { Children's Health: } \\
\text { Infant mortality rate } \\
\text { (deaths per 1,000 live } \\
\text { births) }\end{array}$ & $\begin{array}{l}\text { Infant mortality rate (IMR) is the probability of a child dying } \\
\text { between birth and the age of one, expressed per 1,000 live } \\
\text { births. The indicator is used as a measure of children's well- } \\
\text { being and the level of effort being made to maintain child } \\
\text { health. Over three-quarters of child deaths in the developing } \\
\text { world are caused by diseases that can be prevented or cured } \\
\text { by low-cost interventions such as immunization, oral } \\
\text { rehydration therapy (ORT), and antibiotics. Quoted from the } \\
\text { Earth Trends portal. }\end{array}$ & $\begin{array}{l}\text { United Nations Children's Fund (UNICEF). } \\
\text { 2006. The State of the World's Children } \\
\text { 2007: The Double Dividend of Gender } \\
\text { Equality. Table 1. New York: UNICEF. } \\
\text { Available online at: } \\
\text { http://www.unicef.org/sowc07/. }\end{array}$ \\
\hline
\end{tabular}


Table D-1 (continued)

\begin{tabular}{|c|c|c|}
\hline Metric & Definition & Original Source \\
\hline $\begin{array}{l}\text { Children's Health: } \\
\text { Stunting in children } \\
\text { under 5--moderate } \\
\text { and severe (\%) }\end{array}$ & $\begin{array}{l}\text { Stunting in children under } 5 \text { â } €^{\prime \prime} \text { moderate and severe, an } \\
\text { indicator of child malnutrition, refers to the proportion of } \\
\text { children under } 5 \text { whose height-for-age is below minus } 2 \\
\text { standard deviations (for moderate stunting) or below minus } 3 \\
\text { standard deviations (for severe stunting) from the median } \\
\text { height-for-age of an international reference population } \\
\text { recognized by the World Health Organization (WHO). The } \\
\text { values presented here, reported by the United Nations } \\
\text { Childrenâ } €^{\mathrm{TM}} \text { Fund (UNICEF), include both moderate and } \\
\text { severe stunting in children. Quoted from the Earth Trends } \\
\text { portal. }\end{array}$ & $\begin{array}{l}\text { United Nations Children's Fund (UNICEF). } \\
\text { 2006. The State of the World's Children } \\
\text { 2007: The Double Dividend of Gender } \\
\text { Equality. Table 2. New York: UNICEF. } \\
\text { Available online at: } \\
\text { http://www.unicef.org/sowc07/. }\end{array}$ \\
\hline $\begin{array}{l}\text { Children's Health: } \\
\text { Under-5 mortality rate } \\
\text { (deaths per 1,000 live } \\
\text { births) }\end{array}$ & $\begin{array}{l}\text { Under- } 5 \text { mortality rate (U5MR) is the probability of a child } \\
\text { dying between birth and the age of five, expressed per 1,000 } \\
\text { live births. The indicator is used as a measure of children's } \\
\text { well-being and the level of effort being made to maintain child } \\
\text { health. Over three-quarters of child deaths in the developing } \\
\text { world are caused by diseases that can be prevented or cured } \\
\text { by low-cost interventions such as immunization, oral } \\
\text { rehydration therapy (ORT), and antibiotics. Quoted from the } \\
\text { Earth Trends portal. }\end{array}$ & $\begin{array}{l}\text { United Nations Children's Fund (UNICEF). } \\
\text { 2006. The State of the World's Children } \\
\text { 2007: The Double Dividend of Gender } \\
\text { Equality. Tables } 1 \text { and } 10 \text {. New York: } \\
\text { UNICEF. Available online at: } \\
\text { http://www.unicef.org/sowc07/. }\end{array}$ \\
\hline
\end{tabular}


Table D-1 (continued)

\begin{tabular}{|c|c|c|}
\hline Metric & Definition & Original Source \\
\hline $\begin{array}{l}\text { Children's Health: } \\
\text { Underweight children } \\
\text { under 5--moderate } \\
\text { and severe (\%) }\end{array}$ & $\begin{array}{l}\text { Underweight children under } 5 a \hat{f} €^{\prime \prime} \text { moderate and severe, an } \\
\text { indicator of child malnutrition, refers to the proportion of } \\
\text { children under } 5 \text { whose weight-for-age is below minus } 2 \\
\text { standard deviations (for moderate underweight) or below } \\
\text { minus } 3 \text { standard deviations (for severe underweight) from the } \\
\text { median weight-for-age of an international reference } \\
\text { population recognized by the World Health Organization } \\
\text { (WHO). The values presented here, reported by the United } \\
\text { Nations Childrenâ } €^{\mathrm{TM}} \mathrm{S} \text { Fund (UNICEF), include both moderately } \\
\text { and severely underweight children. Quoted from the Earth } \\
\text { Trends portal. }\end{array}$ & $\begin{array}{l}\text { United Nations Children's Fund (UNICEF). } \\
\text { 2006. The State of the World's Children } \\
\text { 2007: The Double Dividend of Gender } \\
\text { Equality. Table 2. New York: UNICEF. } \\
\text { Available online at: } \\
\text { http://www.unicef.org/sowc07/. }\end{array}$ \\
\hline $\begin{array}{l}\text { Children's Health: } \\
\text { Wasting in children } \\
\text { under 5--moderate } \\
\text { and severe (\%) }\end{array}$ & $\begin{array}{l}\text { Wasting in children under 5â } €^{\prime \prime} \text { moderate and severe, an } \\
\text { indicator of child malnutrition, refers to the proportion of } \\
\text { children under } 5 \text { whose weight-for-height is below minus } 2 \\
\text { standard deviations (for moderate wasting) or below minus } 3 \\
\text { standard deviations (for severe wasting) from the median } \\
\text { weight-for-height of an international reference population } \\
\text { recognized by the World Health Organization (WHO). The } \\
\text { values presented here, reported by the United Nations } \\
\text { Childrenâ } €^{\mathrm{TM}} \text { s Fund (UNICEF), include both moderate and } \\
\text { severe wasting in children. Quoted from the Earth Trends } \\
\text { portal. }\end{array}$ & $\begin{array}{l}\text { United Nations Children's Fund (UNICEF). } \\
\text { 2006. The State of the World's Children } \\
\text { 2007: The Double Dividend of Gender } \\
\text { Equality. Table 2. New York: UNICEF. } \\
\text { Available online at: } \\
\text { http://www.unicef.org/sowc07/. }\end{array}$ \\
\hline
\end{tabular}


Table D-1 (continued)

\begin{tabular}{|c|c|c|}
\hline Metric & Definition & Original Source \\
\hline $\begin{array}{l}\text { Civil Society: Density } \\
\text { of international non- } \\
\text { governmental } \\
\text { organizations with } \\
\text { membership (INGOs } \\
\text { with membership per } \\
\text { million population) } \\
\end{array}$ & $\begin{array}{l}\text { Density of international non-governmental organizations with } \\
\text { membership is the number of international non-governmental } \\
\text { organizations that have either member organizations or } \\
\text { individuals in each country per } 1 \text { million population. Quoted } \\
\text { from the Earth Trends portal. }\end{array}$ & $\begin{array}{l}\text { Center for the Study of Global } \\
\text { Governance. 2004. Global Civil Society } \\
\text { 2004/5. H. Anheier et al., eds. London: } \\
\text { Sage. Available online at: } \\
\text { http://www.Ise.ac.uk/Depts/global/yearb } \\
\text { ook04chapters.htm. }\end{array}$ \\
\hline $\begin{array}{l}\text { CO2 Emissions per } \\
\text { capita (metric tons } \\
\text { per capita) }\end{array}$ & $\begin{array}{l}\mathrm{CO} 2 \text { emissions per capita represents the mass of carbon } \\
\text { dioxide (CO2) emitted per person for a country or region. Data } \\
\text { are given in metric tons. Quoted from the Earth Trends portal. }\end{array}$ & $\begin{array}{l}\text { Climate Analysis Indicators Tool (CAIT) } \\
\text { version 3.0. (Washington, DC: World } \\
\text { Resources Institute, 2005). Available at } \\
\text { http://cait.wri.org. }\end{array}$ \\
\hline $\begin{array}{l}\text { Consumption of } \\
\text { domestic water } \\
\text { (internal footprint) } \\
\text { (m3/cap/year) }\end{array}$ & $\begin{array}{l}\text { "The water footprint of an individual, community or business is } \\
\text { defined as the total volume of freshwater that is used to } \\
\text { produce the goods and services consumed by the individual or } \\
\text { community or produced by the business." Water Footprint } \\
\text { Network Homepage } \\
\text { http://www.waterfootprint.org/?page=files/home }\end{array}$ & $\begin{array}{l}\text { Hoekstra, A.Y. and Chapagain, A.K. (2008) } \\
\text { Globalization of water: Sharing the } \\
\text { planet's freshwater resources, Blackwell } \\
\text { Publishing, Oxford, UK. }\end{array}$ \\
\hline $\begin{array}{l}\text { Contracepitve } \\
\text { Prevalence Rate (\% of } \\
\text { married women aged } \\
15-49 \text { practicing } \\
\text { contraception) }\end{array}$ & $\begin{array}{l}\text { "Contraceptive prevalence rate is the percentage of women } \\
\text { who are practicing, or whose sexual partners are practicing, } \\
\text { any form of contraception. It is usually measured for married } \\
\text { women age } 15-49 \text { only." Quoted from the SEDAC Data } \\
\text { Dictionary. }\end{array}$ & World Bank SIMA and WDI online \\
\hline $\begin{array}{l}\text { Corruption: Bribe } \\
\text { Payer's Index (score } \\
\text { from } 0 \text { to } 10 \text {, with } 10 \\
\text { being the "best") }\end{array}$ & $\begin{array}{l}\text { The Bribe Payer's Index (BPI) measures the tendency of firms } \\
\text { from top exporting countries to pay bribes or make } \\
\text { undocumented payments while conducting business abroad. } \\
\text { Ratings range in value from } 10 \text { (bribes never occur) to } 0 \text { (bribes } \\
\text { occur often). Quoted from the Earth Trends portal. }\end{array}$ & $\begin{array}{l}\text { Transparency International. 2006. } 2006 \\
\text { Bribe Payer's Index. Berlin: Transparency } \\
\text { International. Available online at: } \\
\text { http://www.transparency.org/policy_rese } \\
\text { arch/surveys indices/bpi/bpi_2006\#pr. }\end{array}$ \\
\hline
\end{tabular}


Table D-1 (continued)

\begin{tabular}{|c|c|c|}
\hline Metric & Definition & Original Source \\
\hline $\begin{array}{l}\text { Death rate from } \\
\text { intestinal infectious } \\
\text { diseases (deaths per } \\
100,000 \text { population) }\end{array}$ & $\begin{array}{l}\text { "Indicator of the degree to which the population is affected by } \\
\text { poor sanitation and water quality, which are related to } \\
\text { environmental conditions." Quoted from the SEDAC Data } \\
\text { Dictionary. }\end{array}$ & $\begin{array}{l}\text { World Health Organization (WHO), } \\
\text { Mortality databases for International } \\
\text { Classification of Deaths (ICD) revisions } 9 \\
\text { and 10, July } 2004\end{array}$ \\
\hline $\begin{array}{l}\text { Debt: Total debt } \\
\text { service (current US\$ } \\
\text { per person) }\end{array}$ & $\begin{array}{l}\text { Total debt service is the sum of principal repayments and } \\
\text { interest actually paid in foreign currency, goods, or services on } \\
\text { long-term debt, interest paid on short-term debt, and } \\
\text { repayments (repurchases and charges) to the International } \\
\text { Monetary Fund (IMF). Both long-term public and private debt } \\
\text { are included. Private debt is an external obligation of a private } \\
\text { debtor that is not guaranteed by a public entity. Data are in } \\
\text { million current U.S. dollars. Quoted from the Earth Trends } \\
\text { portal. }\end{array}$ & $\begin{array}{l}\text { Development Data Group, The World } \\
\text { Bank. 2008. } 2008 \text { World Development } \\
\text { Indicators Online. Washington, DC: The } \\
\text { World Bank. Available at: } \\
\text { http://go.worldbank.org/UOFSM7AQ40. }\end{array}$ \\
\hline $\begin{array}{l}\text { Demographics: Crude } \\
\text { birth rate (births per } \\
1,000 \text { people) }\end{array}$ & $\begin{array}{l}\text { Crude birth rate refers to the average number of births in a } \\
\text { year, expressed per 1,000 population. Crude birth rate } \\
\text { provides a rough measure of fertility. The projections } \\
\text { reported here assume medium fertility (the "medium-fertility } \\
\text { assumption" of the United Nations Population Division). } \\
\text { Quoted from the Earth Trends portal. }\end{array}$ & $\begin{array}{l}\text { Population Division of the Department of } \\
\text { Economic and Social Affairs of the United } \\
\text { Nations Secretariat. 2007. World } \\
\text { Population Prospects: The } 2006 \text { Revision. } \\
\text { Dataset on CD-ROM. New York: United } \\
\text { Nations. Available on-line at } \\
\text { http://www.un.org/esa/population/orderi } \\
\text { ng.htm }\end{array}$ \\
\hline
\end{tabular}


Table D-1 (continued)

\begin{tabular}{|c|c|c|}
\hline Metric & Definition & Original Source \\
\hline $\begin{array}{l}\text { Demographics: Crude } \\
\text { death rate (deaths per } \\
1,000 \text { people) }\end{array}$ & $\begin{array}{l}\text { Crude death rate refers to the average number of deaths in a } \\
\text { year, expressed per } 1,000 \text { population. Crude death rate } \\
\text { provides a rough measure of mortality. The projections } \\
\text { reported here assume medium fertility (the "medium-fertility } \\
\text { assumption" of the United Nations Population Division). } \\
\text { Quoted from the Earth Trends portal. }\end{array}$ & $\begin{array}{l}\text { Population Division of the Department of } \\
\text { Economic and Social Affairs of the United } \\
\text { Nations Secretariat. 2007. World } \\
\text { Population Prospects: The } 2006 \text { Revision. } \\
\text { Dataset on CD-ROM. New York: United } \\
\text { Nations. Available on-line at } \\
\text { http://www.un.org/esa/population/orderi } \\
\text { ng.htm }\end{array}$ \\
\hline $\begin{array}{l}\text { Demographics: Life } \\
\text { expectancy at birth, } \\
\text { both sexes (years) }\end{array}$ & $\begin{array}{l}\text { Life expectancy at birth, both sexes is the average number of } \\
\text { years that a newborn baby is expected to live if the age- } \\
\text { specific mortality rates effective at the year of birth apply } \\
\text { throughout his or her lifetime. The projections reported here } \\
\text { assume medium fertility (the "medium-fertility assumption" of } \\
\text { the United Nations Population Division). Quoted from the } \\
\text { Earth Trends portal. }\end{array}$ & $\begin{array}{l}\text { Population Division of the Department of } \\
\text { Economic and Social Affairs of the United } \\
\text { Nations Secretariat, 2007. World } \\
\text { Population Prospects: The } 2006 \text { Revision. } \\
\text { Dataset on CD-ROM. New York: United } \\
\text { Nations. Available on-line at } \\
\text { http://www.un.org/esa/population/orderi } \\
\text { ng.htm }\end{array}$ \\
\hline $\begin{array}{l}\text { Demographics: Net } \\
\text { number of migrants } \\
\text { (thousands of people) }\end{array}$ & $\begin{array}{l}\text { Net number of migrants measures the number of people } \\
\text { entering or leaving a country or region annually during each } \\
\text { time period specified. It is calculated as the total number of } \\
\text { immigrants (people entering the country) less the number of } \\
\text { emigrants (people leaving the country) in a five-year period. } \\
\text { The projections reported here assume medium fertility (the } \\
\text { "medium-fertility assumption" of the United Nations } \\
\text { Population Division). Quoted from the Earth Trends portal. }\end{array}$ & $\begin{array}{l}\text { Population Division of the Department of } \\
\text { Economic and Social Affairs of the United } \\
\text { Nations Secretariat, 2007. World } \\
\text { Population Prospects: The } 2006 \text { Revision. } \\
\text { Dataset on CD-ROM. New York: United } \\
\text { Nations. Available on-line at } \\
\text { http://www.un.org/esa/population/orderi } \\
\text { ng.htm }\end{array}$ \\
\hline
\end{tabular}


Table D-1 (continued)

\begin{tabular}{|c|c|c|}
\hline Metric & Definition & Original Source \\
\hline $\begin{array}{l}\text { Demographics: Total } \\
\text { fertility rate (children } \\
\text { per woman) }\end{array}$ & $\begin{array}{l}\text { Total fertility rate is an estimate of the number of children an } \\
\text { average woman would have if current age-specific fertility } \\
\text { rates remained constant during her reproductive years. The } \\
\text { projections reported here assume medium fertility (the } \\
\text { "medium-fertility assumption" of the United Nations } \\
\text { Population Division). Quoted from the Earth Trends portal. }\end{array}$ & $\begin{array}{l}\text { Population Division of the Department of } \\
\text { Economic and Social Affairs of the United } \\
\text { Nations Secretariat. 2007. World } \\
\text { Population Prospects: The } 2006 \text { Revision. } \\
\text { Dataset on CD-ROM. New York: United } \\
\text { Nations. Available on-line at } \\
\text { http://www.un.org/esa/population/orderi } \\
\text { ng.htm }\end{array}$ \\
\hline $\begin{array}{l}\text { Desertification Sub- } \\
\text { Index (Standardized } \\
\text { unit scale - from 1-7; } \\
\text { with } 1 \text { as good and } 7 \\
\text { as bad) }\end{array}$ & $\begin{array}{l}\text { This Sub-Index is an unweighted average of the scores for } \\
\text { several EVI variables. Quoted from the SEDAC Data Dictionary. }\end{array}$ & $\begin{array}{l}\text { Kaly, U.L., Pratt, C.R. and Mitchell, J. } 2004 . \\
\text { The Demonstration Environmental } \\
\text { Vulnerability Inde (EVI) } 2004 \text {. SOPAC } \\
\text { Technical Report 384, } 323 \text { pp. }\end{array}$ \\
\hline $\begin{array}{l}\text { Development } \\
\text { Assistance: (external) } \\
\text { Aid as a percent of } \\
\text { government } \\
\text { expenditure }\end{array}$ & $\begin{array}{l}\text { Aid as a percent of government expenditure is the amount of } \\
\text { official development assistance (ODA) received by a country as } \\
\text { a percentage of its central government expenditure. This } \\
\text { indicator provides a measure of the recipient country's } \\
\text { dependency on aid. Quoted from the Earth Trends portal. }\end{array}$ & $\begin{array}{l}\text { Development Data Group, The World } \\
\text { Bank. 2008. } 2008 \text { World Development } \\
\text { Indicators Online. Washington, DC: The } \\
\text { World Bank. Available at: } \\
\text { http://go.worldbank.org/UOFSM7AQ40. }\end{array}$ \\
\hline $\begin{array}{l}\text { Development } \\
\text { Assistance: Aid } \\
\text { received as a percent } \\
\text { of GNI }\end{array}$ & $\begin{array}{l}\text { Aid as a percent of GNI is the amount of official development } \\
\text { assistance (ODA) received by a country as a percentage of its } \\
\text { Gross National Income (GNI), a measure of citizens' income. } \\
\text { This indicator provides a measure of the recipient country's } \\
\text { dependency on aid. Quoted from the Earth Trends portal. }\end{array}$ & $\begin{array}{l}\text { Development Data Group, The World } \\
\text { Bank. 2008. } 2008 \text { World Development } \\
\text { Indicators Online. Washington, DC: The } \\
\text { World Bank. Available at: } \\
\text { http://go.worldbank.org/UOFSM7AQ40. }\end{array}$ \\
\hline $\begin{array}{l}\text { Dissolved oxygen } \\
\text { concentration (mg. } \\
\text { dissolved oxygen per } \\
\text { liter water) }\end{array}$ & $\begin{array}{l}\text { "A measure of eutrophication, which has an important impact } \\
\text { on the health of aquatic resources and ecosystems. High } \\
\text { levels correspond to low eutrophication." Quoted from the } \\
\text { SEDAC Data Dictionary. }\end{array}$ & $\begin{array}{l}\text { Socioeconomic Data and Applications } \\
\text { Center (SEDAC), Center for International } \\
\text { Earth Science Information Network } \\
\text { (CIESIN), Columbia University }\end{array}$ \\
\hline
\end{tabular}


Table D-1 (continued)

\begin{tabular}{|l|l|l|}
\hline \multicolumn{1}{|c|}{ Metric } & \multicolumn{1}{|c|}{ Definition } & \multicolumn{1}{c|}{ Original Source } \\
\hline $\begin{array}{l}\text { EF: Built-up land } \\
\text { footprint - \% of total } \\
\text { ecological footprint }\end{array}$ & $\begin{array}{l}\text { Use of use of built-up land as a \% of total land used for } \\
\text { consumption (footprint). }\end{array}$ & $\begin{array}{l}\text { Global Footprint Network. National } \\
\text { Footprint Accounts. 2008 Edition }\end{array}$ \\
\hline $\begin{array}{l}\text { EF: Carbon footprint - } \\
\text { \% of total ecological } \\
\text { footprint }\end{array}$ & Use of carbon sinks as a \% of total footprint. & $\begin{array}{l}\text { Global Footprint Network. National } \\
\text { Footprint Accounts. 2008 Edition }\end{array}$ \\
\hline $\begin{array}{l}\text { EF: Cropland footprint } \\
\text { - \% of total ecological } \\
\text { footprint }\end{array}$ & Use of croplands as a \% of total footprint. & $\begin{array}{l}\text { Global Footprint Network. National } \\
\text { Footprint Accounts. 2008 Edition }\end{array}$ \\
\hline $\begin{array}{l}\text { EF: Grazing footprint - } \\
\% \text { of total ecological } \\
\text { footprint }\end{array}$ & Use of grazing land as a \% of total footprint. & $\begin{array}{l}\text { Global Footprint Network. National } \\
\text { Footprint Accounts. 2008 Edition }\end{array}$ \\
\hline $\begin{array}{l}\text { Education: Primary } \\
\text { school net enrollment } \\
\text { ratio (\%) }\end{array}$ & $\begin{array}{l}\text { Primary school net enrollment ratio (NER) is the total primary } \\
\text { school enrollment (both sexes) of the official primary school } \\
\text { age group expressed as a percentage of the population from } \\
\text { the same age group. The theoretical maximum value is 100\%. } \\
\text { A high NER denotes a high degree of participation of the } \\
\text { official school-age population in education. If the NER is below } \\
100 \%, \text { users should not assume that the remaining school- } \\
\text { aged population is not enrolled in any school; they could be } \\
\text { enrolled in school at other grade levels. }\end{array}$ & $\begin{array}{l}\text { United Nations Educational, Scientific, and } \\
\text { for Statistics. 2006. World Education } \\
\text { Indicators. Paris: UNESCO. Available online } \\
\text { at } \\
\text { http://www.uis.unesco.org/ev.php?URL_I } \\
\text { D=5263\&URL_DO=DO_TOPIC\&URL_SECTI } \\
\text { ON=201. }\end{array}$ \\
\hline
\end{tabular}


Table D-1 (continued)

\begin{tabular}{|c|c|c|}
\hline Metric & Definition & Original Source \\
\hline $\begin{array}{l}\text { Education: Secondary } \\
\text { school gender parity } \\
\text { in gross enrollment } \\
\text { (Index value; } 100 \text { = } \\
\text { enrollment equality) }\end{array}$ & $\begin{array}{l}\text { Secondary school gender parity in gross enrollment represents } \\
\text { the ratio of female to male gross enrollment in secondary } \\
\text { schooling. A ratio of } 100 \text { indicates equality in representation. } \\
\text { Values below (above) } 100 \text { indicate a higher (lower) ratio of } \\
\text { male to female enrollment in secondary education. Quoted } \\
\text { from the Earth Trends portal. }\end{array}$ & $\begin{array}{l}\text { United Nations Educational, Scientific, and } \\
\text { Cultural Organization (UNESCO) Institute } \\
\text { for Statistics. 2006. World Education } \\
\text { Indicators. Paris: UNESCO. Available online } \\
\text { at } \\
\text { http://www.uis.unesco.org/ev.php?URL_I } \\
\text { D=5263\&URL_DO=DO_TOPIC\&URL_SECTI } \\
\text { ON=201. }\end{array}$ \\
\hline $\begin{array}{l}\text { Electricity } \\
\text { consumption per } \\
\text { capita (kWh per } \\
\text { person) }\end{array}$ & $\begin{array}{l}\text { Electricity consumption per capita measures the average } \\
\text { kilowatt-hours (kWh) of electrical power generated per person } \\
\text { in a particular country or region. Public electricity plants, } \\
\text { private electricity plants, and combined heat and power (CHP) } \\
\text { plants as well as production by nuclear and hydro (excluding } \\
\text { pumped storage production), geothermal, etc. Electricity } \\
\text { produced by heat from chemical processes is not included } \\
\text { here. Electricity consumption equals production + imports - } \\
\text { exports - distribution losses. Quoted from the Earth Trends } \\
\text { portal. }\end{array}$ & $\begin{array}{l}\text { International Energy Agency (IEA) } \\
\text { Statistics Division. 2007. Energy Balances } \\
\text { of OECD Countries ( } 2008 \text { edition)-- } \\
\text { Economic Indicators and Energy Balances } \\
\text { of Non-OECD Countries ( } 2007 \text { edition)-- } \\
\text { Economic Indicators. Paris: IEA. Available } \\
\text { at } \\
\text { http://data.iea.org/ieastore/default.asp. }\end{array}$ \\
\hline $\begin{array}{l}\text { Energy Consumption } \\
\text { by Source: Biogas and } \\
\text { liquid biomass (ktoe } \\
\text { per million persons) }\end{array}$ & $\begin{array}{l}\text { Energy Consumption by Source: Biogas and liquid biomass } \\
\text { measures the amount of primary energy consumed from } \\
\text { biogas and liquid biomass sources. Data are reported in } \\
\text { thousand tonnes of oil equivalent (ktoe). Quoted from the } \\
\text { Earth Trends portal. This metric was originally published as an } \\
\text { absolute number, and was transformed into a per capita figure } \\
\text { using the countries' total population. }\end{array}$ & $\begin{array}{l}\text { International Energy Agency (IEA) } \\
\text { Statistics Division. 2008. Energy Balances } \\
\text { of OECD Countries ( } 2006 \text { edition) and } \\
\text { Energy Balances of Non-OECD Countries } \\
\text { (2006 edition). Paris: IEA. Available at } \\
\text { http://data.iea.org/ieastore/default.asp. }\end{array}$ \\
\hline
\end{tabular}


Table D-1 (continued)

\begin{tabular}{|c|c|c|}
\hline Metric & Definition & Original Source \\
\hline $\begin{array}{l}\text { Energy Consumption } \\
\text { by Source: } \\
\text { Hydroelectric (ktoe } \\
\text { per million persons) }\end{array}$ & $\begin{array}{l}\text { Energy Consumption by Source: Hydroelectric measures the } \\
\text { amount of primary energy consumed from water power } \\
\text { sources in a particular country or region. Data are reported in } \\
\text { thousand tonnes of oil equivalent (ktoe). Quoted from the } \\
\text { Earth Trends portal. This metric was originally published as an } \\
\text { absolute number, and was transformed into a per capita figure } \\
\text { using the countries' total population. }\end{array}$ & $\begin{array}{l}\text { International Energy Agency (IEA) } \\
\text { Statistics Division. 2007. Energy Balances } \\
\text { of OECD Countries ( } 2008 \text { edition) and } \\
\text { Energy Balances of Non-OECD Countries } \\
\text { (2007 edition). Paris: IEA. Available at } \\
\text { http://data.iea.org/ieastore/default.asp. }\end{array}$ \\
\hline $\begin{array}{l}\text { Energy Consumption } \\
\text { by Source: Solar, } \\
\text { wind, and wave (ktoe } \\
\text { per million persons) }\end{array}$ & $\begin{array}{l}\text { Energy Consumption by Source: Solar, wind, and wave } \\
\text { measures the amount of primary energy consumed from solar } \\
\text { photovoltaic, solar thermal, wind, and ocean sources. Data are } \\
\text { reported in thousand tonnes of oil equivalent (ktoe). Quoted } \\
\text { from the Earth Trends portal. }\end{array}$ & $\begin{array}{l}\text { International Energy Agency (IEA) } \\
\text { Statistics Division. 2006. Energy Balances } \\
\text { of OECD Countries ( } 2006 \text { edition) and } \\
\text { Energy Balances of Non-OECD Countries } \\
\text { (2006 edition). Paris: IEA. Available at } \\
\text { http://data.iea.org/ieastore/default.asp. }\end{array}$ \\
\hline $\begin{array}{l}\text { Energy Consumption: } \\
\text { Residential energy } \\
\text { consumption per } \\
\text { capita (kgoe per } \\
\text { person) }\end{array}$ & $\begin{array}{l}\text { Residential energy consumption per capita measures the } \\
\text { amount of primary energy from all sources consumed by the } \\
\text { residential sector in each country on a per person basis in the } \\
\text { year specified. Data are reported in kilograms of oil equivalent } \\
\text { (kgoe) per person. Quoted from the Earth Trends portal. }\end{array}$ & $\begin{array}{l}\text { International Energy Agency (IEA) } \\
\text { Statistics Division. 2007. Energy Balances } \\
\text { of OECD Countries (2008 edition) and } \\
\text { Energy Balances of Non-OECD Countries } \\
\text { (2007 edition). Paris: IEA. Available at } \\
\text { http://data.iea.org/ieastore/default.asp. }\end{array}$ \\
\hline $\begin{array}{l}\text { Energy Consumption: } \\
\text { Total energy } \\
\text { consumption per } \\
\text { capita (kgoe per } \\
\text { person) }\end{array}$ & $\begin{array}{l}\text { Total energy consumption per capita measures the amount of } \\
\text { primary energy consumed, on average, by each person living in } \\
\text { a particular country or region for the year indicated. All } \\
\text { primary sources of energy, including coal and coal products, oil } \\
\text { and petroleum products, natural gas, nuclear, hydroelectric, } \\
\text { etc., are included here. Data are reported in kilograms of oil } \\
\text { equivalent (kgoe) per person. Quoted from the Earth Trends } \\
\text { portal. }\end{array}$ & $\begin{array}{l}\text { International Energy Agency (IEA) } \\
\text { Statistics Division. 2007. Energy Balances } \\
\text { of OECD Countries ( } 2008 \text { edition) and } \\
\text { Energy Balances of Non-OECD Countries } \\
\text { (2007 edition). Paris: IEA. Available at } \\
\text { http://data.iea.org/ieastore/default.asp. }\end{array}$ \\
\hline
\end{tabular}


Table D-1 (continued)

\begin{tabular}{|l|l|l|}
\hline \multicolumn{1}{|c|}{ Metric } & \multicolumn{1}{|c|}{ Definition } & \multicolumn{1}{c|}{ Original Source } \\
\hline $\begin{array}{l}\text { Foreign Direct } \\
\text { Investments, net } \\
\text { inflows (\% of GDP) }\end{array}$ & Foreign Direct Investments, net inflows as a \% of GDP. & $\begin{array}{l}\text { Calculated on the basis of data on foreign } \\
\text { direct investment and GDP from World } \\
\text { Bank. 2007b. World Development } \\
\text { Indicators 2007. CD-ROM. Washington, } \\
\text { D.C. (UNDP HDI 2008 Report) }\end{array}$ \\
\hline $\begin{array}{l}\text { Forest (Paper) } \\
\begin{array}{l}\text { Production: } \\
\text { Recovered paper } \\
\text { (metric tons per } \\
\text { thousand persons) }\end{array}\end{array}$ & $\begin{array}{l}\text { Production of recovered paper describes the amount of waste } \\
\text { and scrap of paper or paperboard used in the production of } \\
\text { paper products in a given country in a given year. This } \\
\text { commodity includes paper and paperboard which has been } \\
\text { used for its original purpose and residues from paper } \\
\text { conversion, including waste and scrap collected for re-use as a } \\
\text { raw material for the manufacture of paper and related } \\
\text { products. DIVIDED BY POP. Quoted from the Earth Trends } \\
\text { portal. }\end{array}$ & $\begin{array}{l}\text { Food and Agriculture Organization of the } \\
\text { United Nations (FAO). 2008. FAOSTAT } \\
\text { Online Statistical Service. Rome: FAO. } \\
\text { Available online at: http://faostat.fao.org/. }\end{array}$ \\
\hline $\begin{array}{l}\text { GDP per capita, } \\
\text { annual growth rate } \\
\text { (\%) }\end{array}$ & $\begin{array}{l}\text { Gross Domestic Product (GDP) per capita, annual growth rate } \\
\text { country's economy in constant prices per person. GDP per } \\
\text { capita is the total market value of all final goods and services } \\
\text { produced in a country in a given year, equal to total consumer, } \\
\text { investment, and government spending, divided by the mid- } \\
\text { year population. Quoted from the Earth Trends portal. }\end{array}$ & $\begin{array}{l}\text { Adapted from the World Bank's World } \\
\text { Development Indicators }\end{array}$ \\
\hline
\end{tabular}


Table D-1 (continued)

\begin{tabular}{|c|c|c|}
\hline Metric & Definition & Original Source \\
\hline $\begin{array}{l}\text { GDP per capita, PPP, } \\
\text { current international } \\
\text { dollars }\end{array}$ & $\begin{array}{l}\text { Gross Domestic Product (GDP) per capita, PPP is the total } \\
\text { annual output of a country's economy, here in current } \\
\text { international dollars, per person. GDP per capita is the total } \\
\text { market value of all final goods and services produced in a } \\
\text { country in a given year, equal to total consumer, investment, } \\
\text { and government spending, divided by the mid-year } \\
\text { population. Here, it is converted into current international } \\
\text { dollars using Purchasing Power Parity (PPP) rates. Quoted } \\
\text { from the Earth Trends portal. }\end{array}$ & $\begin{array}{l}\text { Development Data Group, The World } \\
\text { Bank. 2008. } 2008 \text { World Development } \\
\text { Indicators Online. Washington, DC: The } \\
\text { World Bank. Available at: } \\
\text { http://go.worldbank.org/UOFSM7AQ40. }\end{array}$ \\
\hline $\begin{array}{l}\text { GDP: Official exchange } \\
\text { rate (local currency / } \\
\text { US dollars) }\end{array}$ & $\begin{array}{l}\text { Official exchange rate is the exchange rate determined by } \\
\text { national authorities or the rate determined in the legally } \\
\text { sanctioned exchange market. It is calculated as an annual } \\
\text { average based on monthly averages and is expressed as the } \\
\text { number of local currency units equivalent to a U.S. dollar. } \\
\text { Quoted from the Earth Trends portal. }\end{array}$ & $\begin{array}{l}\text { Development Data Group, The World } \\
\text { Bank. 2008. } 2008 \text { World Development } \\
\text { Indicators Online. Washington, DC: The } \\
\text { World Bank. Available at: } \\
\text { http://go.worldbank.org/UOFSM7AQ40. }\end{array}$ \\
\hline $\begin{array}{l}\text { Gender } \\
\text { Empowerment } \\
\text { Measure (GEM) } \\
\text { (score, from } 0 \text { to } 1 \text {, } \\
\text { with } 1 \text { being the total } \\
\text { gender equality) }\end{array}$ & $\begin{array}{l}\text { The Gender Empowerment Measure (GEM) is a measure of } \\
\text { inequalities between men's and women's opportunities in a } \\
\text { country. It combines inequalities in three areas: political } \\
\text { participation and decision making, economic participation and } \\
\text { decision making, and power over economic resources. Quoted } \\
\text { from the Wikipedia entry. }\end{array}$ & UNDP HDI 2008 Report \\
\hline
\end{tabular}


Table D-1 (continued)

\begin{tabular}{|l|l|l|}
\hline \multicolumn{1}{|c|}{ Metric } & \multicolumn{1}{|c|}{ Definition } & \multicolumn{1}{c|}{ Original Source } \\
\hline $\begin{array}{l}\text { Investment in } \\
\text { telecommunications } \\
\text { (U.S. dollars per } \\
\text { person) }\end{array}$ & $\begin{array}{l}\text { Investment in telecommunications refers to the annual } \\
\text { expenditure associated with acquiring the ownership of } \\
\text { telecommunication equipment infrastructure for use in a } \\
\text { particular country. Totals include supporting land and } \\
\text { buildings and intellectual and non-tangible property such as } \\
\text { computer software. These include expenditure on initial } \\
\text { installations and on additions to existing installations. Data are } \\
\text { given in thousands of U.S. dollars. Quoted from the Earth } \\
\text { Trends portal. }\end{array}$ & $\begin{array}{l}\text { Indicators 2006. Geneva: ITU. Available } \\
\text { online at http://www.itu.int/ITU- } \\
\text { D/ict/publications/world/world.html. }\end{array}$ \\
\hline $\begin{array}{l}\text { Irrigated land as a } \\
\text { percent of total } \\
\text { agricultural area (\%) }\end{array}$ & $\begin{array}{l}\text { Irrigated land as a percent of total agricultural area is the } \\
\text { percentage of a country's total agricultural area which is } \\
\text { equipped to provide water to crops. Types of irrigated land } \\
\text { include full and partial control irrigation, spate irrigation areas, } \\
\text { and equipped wetland or inland valley bottoms. The } \\
\text { agricultural area is defined as the sum of arable and } \\
\text { permanent cropland and permanent pasture. Quoted from } \\
\text { the Earth Trends portal. }\end{array}$ & $\begin{array}{l}\text { Food and Agriculture Organization of the } \\
\text { Online Statistical Service. Rome: FAO. } \\
\text { Available online at: http://faostat.fao.org. }\end{array}$ \\
\hline $\begin{array}{l}\text { Labor: Workers' } \\
\text { remittances and } \\
\text { compensation of } \\
\text { employees, received } \\
\text { (million US\$ per } \\
\text { capita) }\end{array}$ & $\begin{array}{l}\text { Workers' remittances and compensation of employees, } \\
\text { received comprise current transfers by migrant workers and } \\
\text { wages and salaries earned by nonresident workers. Data are } \\
\text { given in million U.S. dollars. DIVIDED BY POP. Quoted from the } \\
\text { Earth Trends portal. }\end{array}$ & $\begin{array}{l}\text { Indicators Online. Washington, DC: The } \\
\text { World Bank. Available at: } \\
\text { http://go.worldbank.org/UOFSM7AQ40. }\end{array}$ \\
\hline
\end{tabular}


Table D-1 (continued)

\begin{tabular}{|l|l|l|}
\hline \multicolumn{1}{|c|}{ Metric } & \multicolumn{1}{|c|}{ Definition } & \multicolumn{1}{c|}{ Original Source } \\
\hline $\begin{array}{l}\text { Land Degradation (\% } \\
\text { of a country's land } \\
\text { area considered } \\
\text { severely and very } \\
\text { severely degraded) }\end{array}$ & $\begin{array}{l}\text { Percent of a country's total land area considered severely and } \\
\text { very severely degraded. }\end{array}$ & $\begin{array}{l}\text { Kaly, U.L., Pratt, C.R. and Mitchell, J. 2004. } \\
\text { The Demonstration Environmental } \\
\text { Vulnerability Inde (EVI) 2004. SOPAC } \\
\text { Technical Report 384, 323 pp. }\end{array}$ \\
\hline $\begin{array}{l}\text { Language } \\
\text { Fractionalization } \\
\text { Index } \\
\text { (fractionalization } \\
\text { score: higher means } \\
\text { more diverse) }\end{array}$ & $\begin{array}{l}\text { Fractionalization is "a measure of diversity among individuals" } \\
\text { (Bossert, et al., 2006) }\end{array}$ & $\begin{array}{l}\text { Alesina, Alberto, et al, 2003. " } \\
\text { Fractionalization," Journal of Economic } \\
\text { Growth, Springer, vol. 8(2), pages 155-94, } \\
\text { June. }\end{array}$ \\
\hline $\begin{array}{l}\text { Literacy: Female } \\
\text { literacy rate as a } \\
\text { percentage of male } \\
\text { literacy rate (\%) }\end{array}$ & $\begin{array}{l}\text { WRI calculates female literacy rate as a percentage of male } \\
\text { literacy rate to measure, in a single variable, gender parity in } \\
\text { literacy. A value of 100\% indicates that female and male } \\
\text { literacy rates are the same. Values less than 100\% indicate } \\
\text { that the female literacy rate is less than the male literacy rate } \\
\text { (e.g., 50\% indicates that the female literacy rate is half that of } \\
\text { male literacy rate). Values greater than 100\% indicate that the } \\
\text { female literacy rate is greater than the male literacy rate for } \\
\text { that country. Quoted from the Earth Trends portal. }\end{array}$ & $\begin{array}{l}\text { United Nations Educational, Scientific, and } \\
\text { Cultural Organization (UNESCO) Institute } \\
\text { for Statistics. 2006. World Education } \\
\text { Indicators, Literacy Statistics. Paris: } \\
\text { UNESCO. Available online at } \\
\text { http://www.uis.unesco.org/ev.php?URL_I } \\
\text { D=6401\&URL_DO=DO_TOPIC\&URL_SECTI } \\
\text { ON=201. }\end{array}$ \\
\hline
\end{tabular}


Table D-1 (continued)

\begin{tabular}{|c|c|c|}
\hline Metric & Definition & Original Source \\
\hline $\begin{array}{l}\text { Literacy: Literacy rate, } \\
\text { all adults (\%) }\end{array}$ & $\begin{array}{l}\text { Though it varies across countries, the adult literacy rate is } \\
\text { usually defined as the percentage of the population aged } 15 \\
\text { years and over who can both read and write, with } \\
\text { comprehension, a short, simple statement regarding their } \\
\text { everyday life. Literacy data can be used to assess gender, age- } \\
\text { group, and geographic patterns of illiteracy within each } \\
\text { country, as well as the achievement of national literacy } \\
\text { programs and policies. According to the United Nations } \\
\text { Educational, Scientific, and Cultural Organization (UNESCO), } \\
\text { "These estimates reflect the performance of the national } \\
\text { education system, as well as the quality of the human } \\
\text { resources within a country in relation to their potential for } \\
\text { growth, contribution to development, and quality of life." } \\
\text { Adult literacy correlates with GNP per capita, life expectancy, } \\
\text { fertility rates, infant mortality, and urbanization. Quoted from } \\
\text { the Earth Trends portal. }\end{array}$ & $\begin{array}{l}\text { United Nations Educational, Scientific, and } \\
\text { Cultural Organization (UNESCO) Institute } \\
\text { for Statistics. 2006. World Education } \\
\text { Indicators, Literacy Statistics. Paris: } \\
\text { UNESCO. Available online at } \\
\text { http://www.uis.unesco.org/ev.php?URL_I } \\
\text { D=6401\&URL_DO=DO_TOPIC\&URL_SECTI } \\
\text { ON=201. }\end{array}$ \\
\hline
\end{tabular}


Table D-1 (continued)

\begin{tabular}{|c|c|c|}
\hline Metric & Definition & Original Source \\
\hline $\begin{array}{l}\text { Literacy: Literacy rate, } \\
\text { youth (age } 15 \text { to } 24) \\
\text { (\%) }\end{array}$ & $\begin{array}{l}\text { Though it varies across countries, the youth literacy rate is } \\
\text { usually defined as the percentage of the population aged 15- } \\
24 \text { years who can both read and write, with comprehension, a } \\
\text { short, simple statement regarding their everyday life. Literacy } \\
\text { data can be used to assess gender, age-group, and geographic } \\
\text { patterns of illiteracy within each country, as well as the } \\
\text { achievement of national literacy programs and policies. } \\
\text { According to the United Nations Educational, Scientific, and } \\
\text { Cultural Organization (UNESCO), "These estimates reflect the } \\
\text { performance of the national education system, as well as the } \\
\text { quality of the human resources within a country in relation to } \\
\text { their potential for growth, contribution to development, and } \\
\text { quality of life." Adult literacy correlates with GNP per capita, } \\
\text { life expectancy, fertility rates, infant mortality, and } \\
\text { urbanization. Quoted from the Earth Trends portal. }\end{array}$ & $\begin{array}{l}\text { United Nations Educational, Scientific, and } \\
\text { Cultural Organization (UNESCO) Institute } \\
\text { for Statistics. 2006. World Education } \\
\text { Indicators, Literacy Statistics. Paris: } \\
\text { UNESCO. Available online at } \\
\text { http://www.uis.unesco.org/ev.php?URL_I } \\
\text { D=6401\&URL_DO=DO_TOPIC\&URL_SECTI } \\
\text { ON=201. }\end{array}$ \\
\hline $\begin{array}{l}\text { Livestock: Goat stocks } \\
\text { (8head per person) }\end{array}$ & $\begin{array}{l}\text { Goat stocks includes all goats in the country, regardless of } \\
\text { place or purpose of their breeding. Goat (Capra spp.) figures } \\
\text { include Hircus, Ibex, Nubiana, Pyrenaica, Tibetana, Kashmir, } \\
\text { and Angora. DIVIDED BY POP. Quoted from the Earth Trends } \\
\text { portal. }\end{array}$ & $\begin{array}{l}\text { Food and Agriculture Organization of the } \\
\text { United Nations (FAO), 2007. FAOSTAT on- } \\
\text { line statistical service. FAO: Rome. Online } \\
\text { at: http://faostat.fao.org/. }\end{array}$ \\
\hline $\begin{array}{l}\text { Local Air Quality Score } \\
\text { (unitless scale - } 0 \text { is } \\
\text { the worst possible } \\
\text { score and } 100 \text { is the } \\
\text { best) }\end{array}$ & $\begin{array}{l}\text { "... is the average of city scores in each country, each city score } \\
\text { being the lowest score of six indicators: sulfure dioxide, } \\
\text { nitrogen dioxide, ground-level ozone, carbon monoxide, } \\
\text { particulates, and lead." Quoted from the SEDAC Data } \\
\text { Dictionary. }\end{array}$ & $\begin{array}{l}\text { Prescott-Allen, Robert. 2001. The } \\
\text { Wellbeing of Nations: A Country-by- } \\
\text { Country Index of Quality of Life and the } \\
\text { Environment. Washington, DC: Island } \\
\text { Press. Table } 17\end{array}$ \\
\hline
\end{tabular}


Table D-1 (continued)

\begin{tabular}{|l|l|l|}
\hline \multicolumn{1}{|c|}{ Metric } & \multicolumn{1}{|c|}{ Definition } & \multicolumn{1}{c|}{ Original Source } \\
\hline $\begin{array}{l}\text { Long term } \\
\text { unemployment (\% of } \\
\text { labor force) }\end{array}$ & $\begin{array}{l}\text { Persons unemployed in the long term as a percent of the total } \\
\text { labor force. }\end{array}$ & $\begin{array}{l}\text { OECD (Organisation for Economic Co- } \\
\text { operation and Development). 2007. OECD } \\
\text { Main Economic Indicators. Paris. } \\
\text { [http://www.oecd.org/statsportal]. } \\
\text { Accessed July 2007. }\end{array}$ \\
\hline $\begin{array}{l}\text { Meat Consumption: } \\
\text { Per capita (Kg. per } \\
\text { person) }\end{array}$ & $\begin{array}{l}\text { Meat consumption per capita refers to the total meat retained } \\
\text { for use in country per person per year. Total meat includes } \\
\text { meat from animals slaughtered in countries, irrespective of } \\
\text { their origin, and comprises horsemeat, poultry, and meat from } \\
\text { all other domestic or wild animals such as camels, rabbits, } \\
\text { reindeer, and game animals. Quoted from the Earth Trends } \\
\text { portal. }\end{array}$ & $\begin{array}{l}\text { Source: Food and Agriculture Organization } \\
\text { of the United Nations (FAO), FAOSTAT on- } \\
\text { line statistical service (FAO, Rome, 2004). } \\
\text { Available online at: http://apps.fao.org. }\end{array}$ \\
\hline $\begin{array}{l}\text { Micro, Small, and } \\
\text { Medium Enterprises: } \\
\text { MSMEs per 1000 } \\
\text { people }\end{array}$ & $\begin{array}{l}\text { MSMEs per 1,000 people refers to the total number of micro, } \\
\text { small, and medium enterprises (MSMEs) per 1,000 people in a } \\
\text { country. MSMEs are defined in this dataset as enterprises } \\
\text { employing no more than 250 employees. Over the last several } \\
\text { years, increasing attention has been paid to the importance of } \\
\text { MSMEs with regard to growth, employment, innovation, } \\
\text { competition, and poverty reduction, though strong evidence } \\
\text { of causal relationships remain elusive. Quoted from the Earth } \\
\text { Trends portal. }\end{array}$ & $\begin{array}{l}\text { Small and Medium Enterprise } \\
\text { Department, International Finance } \\
\text { Corporation (IFC). 2006. Micro, Small, and } \\
\text { Medium Enterprises: A Collection of } \\
\text { Published Data. Washington, DC: IFC. } \\
\text { Available on-line at: } \\
\text { http://www.ifc.org/ifcext/sme.nsf/Conten } \\
\text { t/Resources. }\end{array}$ \\
\hline
\end{tabular}


Table D-1 (continued)

\begin{tabular}{|l|l|l|}
\hline \multicolumn{1}{|c|}{ Metric } & \multicolumn{1}{|c|}{ Definition } & \multicolumn{1}{c|}{ Original Source } \\
\hline $\begin{array}{l}\text { NBI (National } \\
\text { Biodiversity Index) } \\
\text { (score between 0 and } \\
1 \text { with large values } \\
\text { corresponding to high } \\
\text { levels of species } \\
\text { abundance and small } \\
\text { values reflecting low } \\
\text { levels of species } \\
\text { abundance) }\end{array}$ & $\begin{array}{l}\text { The NBI assesses a country's species richness by measuring } \\
\text { species abundance. Quoted from the SEDAC Data Dictionary. }\end{array}$ & $\begin{array}{l}\text { Convention on Biological Diversity, Global } \\
\text { Biodiversity Outlook (2001). }\end{array}$ \\
\hline $\begin{array}{l}\text { Number of } \\
\text { researchers in R\&D } \\
\text { per million inhabitants }\end{array}$ & $\begin{array}{l}\text { "Scientific capacity is important for the development of new } \\
\text { Quoted from the SEDAC Data Dictionary. }\end{array}$ & $\begin{array}{l}\text { World Bank. 2007b. World Development } \\
\text { Indicators 2007. CD-ROM. Washington, } \\
\text { D.C.; aggregates calculated for HDRO by } \\
\text { the World Bank. }\end{array}$ \\
\hline $\begin{array}{l}\text { Nutrition: Calorie } \\
\text { supply per capita from } \\
\text { animal products } \\
\text { (kilocalories/person/d } \\
\text { ay) }\end{array}$ & $\begin{array}{l}\text { Calorie supply from animal products per capita refers to the } \\
\text { amount of available food from animal products, expressed in } \\
\text { calories per person, per day. Animal products include: all } \\
\text { types of meat and fish; animal fats and fish oils; edible offal; } \\
\text { milk, butter, cheese, and cream; and eggs and egg products. } \\
\text { Quoted from the Earth Trends portal. }\end{array}$ & $\begin{array}{l}\text { Food and Agriculture Organization of the } \\
\text { United Nations (FAO), FAOSTAT on-line } \\
\text { statistical service. Available on-line at } \\
\text { http://apps.fao.org. FAO: Rome, 2004. }\end{array}$ \\
\hline
\end{tabular}


Table D-1 (continued)

\begin{tabular}{|c|c|c|}
\hline Metric & Definition & Original Source \\
\hline $\begin{array}{l}\text { Nutrition: Grain fed to } \\
\text { livestock as a percent } \\
\text { of total grain } \\
\text { consumed (\%) }\end{array}$ & $\begin{array}{l}\text { Grain fed to livestock as a percent of total grain consumption } \\
\text { refers to the total domestic consumption of feed grain (grain } \\
\text { consumed by animals) as a percentage of the total domestic } \\
\text { grain consumption. Grains include wheat (including durum } \\
\text { wheat), rice (milled), corn, barley, sorghum, millet, rye, oats, } \\
\text { and mixed grains. Total domestic grain consumption is the } \\
\text { quantity of dried grain used for feed, food, seed, and industrial } \\
\text { purposes during the local 12-month marketing year of an } \\
\text { individual country. Quoted from the Earth Trends portal. }\end{array}$ & $\begin{array}{l}\text { United States Department of Agriculture } \\
\text { (USDA) Foreign Agricultural Service (FAS). } \\
\text { 2007. Production, Supply \& Distribution } \\
\text { Online Database. USDA: Washington, D.C. } \\
\text { Available online at } \\
\text { http://www.fas.usda.gov/psdonline/. }\end{array}$ \\
\hline $\begin{array}{l}\text { Official development } \\
\text { asst. received (net } \\
\text { disbursements) (\% of } \\
\text { GDP) }\end{array}$ & $\begin{array}{l}\text { Official development asst. received (net disbursements) as } \\
\text { percent of GDP. }\end{array}$ & $\begin{array}{l}\text { Calculated on the basis of data on ODA } \\
\text { from OECD-DAC (Organisation for } \\
\text { Economic Co-operation and Development, } \\
\text { Development Assistance Committee). } \\
\text { 2007. Correspondence on official } \\
\text { development assistance disbursed. May. } \\
\text { Paris and GDP from World Bank. 2007b. } \\
\text { World Development Indicators 2007. CD- } \\
\text { ROM. Washington, D.C. (UNDP HDI } 2008 \\
\text { Report) }\end{array}$ \\
\hline $\begin{array}{l}\text { Organic Farming: } \\
\text { Organic land area as a } \\
\text { percent of total } \\
\text { agricultural area }\end{array}$ & $\begin{array}{l}\text { Organic land area as a percent of total agricultural area refers } \\
\text { to the amount of land either fully converted to organic } \\
\text { agriculture or in the process of conversion as a percentage of a } \\
\text { country's total agricultural land. Quoted from the Earth Trends } \\
\text { portal. }\end{array}$ & $\begin{array}{l}\text { Willer, Helga and Yussefi, Minou, Eds. } \\
\text { 2006. The World of Organic Agriculture - } \\
\text { Statistics and Emerging Trends } 2006 . \\
\text { International Federation of Organic } \\
\text { Agriculture Movements (IFOAM). Bonn, } \\
\text { Germany: IFOAM. Available online at: } \\
\text { http://www.ifoam.org/press/press/Statisti } \\
\text { cs_2006.html. }\end{array}$ \\
\hline
\end{tabular}


Table D-1 (continued)

\begin{tabular}{|c|c|c|}
\hline Metric & Definition & Original Source \\
\hline $\begin{array}{l}\text { Other Greenhouse } \\
\text { Gases per capita } \\
\text { (metric tons per } \\
\text { capita) }\end{array}$ & $\begin{array}{l}\text { "...emissions of } \mathrm{CO} 2 \text { other than from burning fuel (see above), } \\
\text { methane (CH4), nitrous oxide (N2O), hydrofluorocarbons } \\
\text { (HFCs), perfluorocarbons (PFCs) and sulphur hexafluoride (SF), } \\
\text { including } \mathrm{CO} 2 \text { emissions/removals from land-use change and } \\
\text { forestry." Quoted from the SEDAC Data Dictionary. }\end{array}$ & $\begin{array}{l}\text { UN Framework Convention on Climate } \\
\text { Change }\end{array}$ \\
\hline $\begin{array}{l}\text { Patents granted to } \\
\text { residents (\# of patents } \\
\text { per million people) }\end{array}$ & Number of patents granted per million people. & $\begin{array}{l}\text { Calculated on the basis of data on patents } \\
\text { from WIPO (World Intellectual Property } \\
\text { Organization). 2007. "Patents Granted by } \\
\text { Office (1985-2005)." Geneva. } \\
\text { [http://wipo.int/ipstats/en/statistics/]. } \\
\text { Accessed May } 2007 \text { and data on } \\
\text { population from UN (United Nations). } \\
\text { 2007e. World Population Prospects 1950- } \\
\text { 2050: The } 2006 \text { Revision. Database. } \\
\text { Department of Economic and Social } \\
\text { Affairs, Population Division. New York. } \\
\text { Accessed July 2007. (UNDP HDI } 2008 \\
\text { Report) }\end{array}$ \\
\hline $\begin{array}{l}\text { Percent GDP from } \\
\text { industry }\end{array}$ & $\begin{array}{l}\text { Percent gross domestic product (GDP) from industry } \\
\text { represents the proportion of an economy's total domestic } \\
\text { output of goods and services which are a result of value added } \\
\text { by the industrial sector. Quoted from the Earth Trends portal. }\end{array}$ & $\begin{array}{l}\text { Development Data Group, The World } \\
\text { Bank. 2008. } 2008 \text { World Development } \\
\text { Indicators Online. Washington, DC: The } \\
\text { World Bank. Available at: } \\
\text { http://go.worldbank.org/UOFSM7AQ40. }\end{array}$ \\
\hline
\end{tabular}


Table D-1 (continued)

\begin{tabular}{|c|c|c|}
\hline Metric & Definition & Original Source \\
\hline $\begin{array}{l}\text { Percent GDP from } \\
\text { manufacturing }\end{array}$ & $\begin{array}{l}\text { Percent gross domestic product (GDP) from manufacturing } \\
\text { represents the proportion of an economy's total domestic } \\
\text { output of goods and services which are a result of value added } \\
\text { by the manufacturing sector. Manufacturing is considered by } \\
\text { the World Bank as part of industry; as such, when summing } \\
\text { GDP percentages, the agriculture sector, the industry sector } \\
\text { and the services sector should roughly equal 100. Quoted } \\
\text { from the Earth Trends portal. }\end{array}$ & $\begin{array}{l}\text { Development Data Group, The World } \\
\text { Bank. 2008. } 2008 \text { World Development } \\
\text { Indicators Online. Washington, DC: The } \\
\text { World Bank. Available at: } \\
\text { http://go.worldbank.org/UOFSM7AQ40. }\end{array}$ \\
\hline $\begin{array}{l}\text { Percentage of the } \\
\text { population with } \\
\text { insufficient food }\end{array}$ & $\begin{array}{l}\text { "Insufficient food means food consumption below minimum } \\
\text { energy requirement." Quoted from the SEDAC Data Dictionary. }\end{array}$ & $\begin{array}{l}\text { Prescott-Allen, Robert. 2001. The } \\
\text { Wellbeing of Nations: A Country-by- } \\
\text { Country Index of Quality of Life and the } \\
\text { Environment. Washington, DC: Island } \\
\text { Press. Table } 3\end{array}$ \\
\hline $\begin{array}{l}\text { Pesticide use (Kg. } \\
\text { pesticides used per } \\
\text { year per } \mathrm{km}^{2} \text { of total } \\
\text { land area) }\end{array}$ & Kg. pesticides used per year per $\mathrm{km}^{2}$ of total land area. & WRI 2000-2001 \& OECD 1999 \\
\hline $\begin{array}{l}\text { Politics and Freedom: } \\
\text { Regulatory Quality } \\
\text { Index (Index: }-2.5 \\
\text { worst governance, } 0 \\
\text { average, } 2.5 \text { best } \\
\text { governance) }\end{array}$ & $\begin{array}{l}\text { The Regulatory Quality Index is a measure of "the incidence of } \\
\text { market unfriendly policies such as price controls or inadequate } \\
\text { bank supervision, as well as perceptions of the burdens } \\
\text { imposed by excessive regulation in areas such as foreign trade } \\
\text { and business development." It attempts to describe the } \\
\text { degree to which governments create an atmosphere that } \\
\text { encourages trade and foreign investment. Quoted from the } \\
\text { Earth Trends portal. }\end{array}$ & $\begin{array}{l}\text { Governance Matters VII: Aggregate and } \\
\text { Individual Governance Indicators, 1996- } \\
\text { 2007. D. Kaufmann, A. Kraay, and M. } \\
\text { Mastruzzi (2008). World Bank Policy } \\
\text { Research Working Paper 4654. Available } \\
\text { online at: } \\
\text { http://go.worldbank.org/2EOSXCR850. }\end{array}$ \\
\hline
\end{tabular}


Table D-1 (continued)

\begin{tabular}{|c|c|c|}
\hline Metric & Definition & Original Source \\
\hline $\begin{array}{l}\text { Population density } \\
\text { (people per square } \\
\mathrm{km}^{2} \text { ) }\end{array}$ & $\begin{array}{l}\text { Population density is the number of persons per square } \\
\text { kilometer of land area. This data set contains estimates for all } \\
\text { countries from } 1950 \text { to } 2005 \text { at five year intervals. The } \\
\text { projections reported here assume medium fertility (the } \\
\text { "medium-fertility assumption" of the United Nations } \\
\text { Population Division). Quoted from the Earth Trends portal. }\end{array}$ & $\begin{array}{l}\text { Population Division of the Department of } \\
\text { Economic and Social Affairs of the United } \\
\text { Nations Secretariat, 2007. World } \\
\text { Population Prospects: The } 2006 \text { Revision. } \\
\text { Dataset on CD-ROM. New York: United } \\
\text { Nations. Available on-line at } \\
\text { http://www.un.org/esa/population/orderi } \\
\text { ng.htm }\end{array}$ \\
\hline $\begin{array}{l}\text { Population using } \\
\text { improved sanitation } \\
\text { (\% of the population) }\end{array}$ & $\begin{array}{l}\text { Population using improved sanitation as a } \% \text { of the total } \\
\text { population }\end{array}$ & $\begin{array}{l}\text { UN (United Nations). 2006a. Millennium } \\
\text { Development Goals Indicators Database. } \\
\text { Department of Economic and Social } \\
\text { Affairs, Statistics Division. New York. } \\
\text { [http://mdgs.un.org]. Accessed May 2007, } \\
\text { based on a joint effort by UNICEF and } \\
\text { WHO. }\end{array}$ \\
\hline $\begin{array}{l}\text { Population without } \\
\text { electricity (\% of the } \\
\text { population) }\end{array}$ & $\begin{array}{l}\text { This metric was originally published as an absolute number } \\
\text { (million persons), and was transformed into a percentage of } \\
\text { the population using the countries' total population. }\end{array}$ & $\begin{array}{l}\text { IEA (International Energy Agency). } 2006 . \\
\text { World Energy Outlook 2006. Paris. }\end{array}$ \\
\hline $\begin{array}{l}\text { Population: Above age } \\
65 \text {, both sexes (\% of } \\
\text { the population) }\end{array}$ & $\begin{array}{l}\text { Population above age } 65 \text {, both sexes refers to the de facto } \\
\text { population of a given country or region older than age } 65 \text { as of } \\
\text { July } 1 \text { of a given year. The projections reported here assume } \\
\text { medium fertility (the "medium-fertility assumption" of the } \\
\text { United Nations Population Division). Divided by pop. Quoted } \\
\text { from the Earth Trends portal. }\end{array}$ & $\begin{array}{l}\text { Population Division of the Department of } \\
\text { Economic and Social Affairs of the United } \\
\text { Nations Secretariat, 2005. World } \\
\text { Population Prospects: The } 2004 \text { Revision. } \\
\text { Dataset on CD-ROM. New York: United } \\
\text { Nations. Available on-line at } \\
\text { http://www.un.org/esa/population/orderi } \\
\text { ng.htm }\end{array}$ \\
\hline
\end{tabular}


Table D-1 (continued)

\begin{tabular}{|c|c|c|}
\hline Metric & Definition & Original Source \\
\hline $\begin{array}{l}\text { Population: Below age } \\
15 \text {, both sexes ( } \% \text { of } \\
\text { the population) }\end{array}$ & $\begin{array}{l}\text { Population below age 15, both sexes refers to the de facto } \\
\text { population of a given country or region below age } 15 \text { as of July } \\
1 \text { of a given year. The projections reported here assume } \\
\text { medium fertility (the "medium-fertility assumption" of the } \\
\text { United Nations Population Division). Quoted from the Earth } \\
\text { Trends portal. This metric was originally published as an } \\
\text { absolute number (million persons), and was transformed into } \\
\text { a percentage of the population using the countries' total } \\
\text { population. }\end{array}$ & $\begin{array}{l}\text { Population Division of the Department of } \\
\text { Economic and Social Affairs of the United } \\
\text { Nations Secretariat, 2005. World } \\
\text { Population Prospects: The } 2004 \text { Revision. } \\
\text { Dataset on CD-ROM. New York: United } \\
\text { Nations. Available on-line at } \\
\text { http://www.un.org/esa/population/orderi } \\
\text { ng.htm }\end{array}$ \\
\hline $\begin{array}{l}\text { Population: Growth } \\
\text { rate of total } \\
\text { population (\%) }\end{array}$ & $\begin{array}{l}\text { Growth rate of total population is the average annual percent } \\
\text { change in mid-year population for a country or region in the } \\
\text { indicated period. Percent changes in population are calculated } \\
\text { using the exponential growth rate equation, which assumes } \\
\text { continuous, exponential growth over time. The projections } \\
\text { reported here assume medium fertility (the "medium-fertility } \\
\text { assumption" of the United Nations Population Division). } \\
\text { Quoted from the Earth Trends portal. }\end{array}$ & $\begin{array}{l}\text { Population Division of the Department of } \\
\text { Economic and Social Affairs of the United } \\
\text { Nations Secretariat. 2007. World } \\
\text { Population Prospects: The } 2006 \text { Revision. } \\
\text { Dataset on CD-ROM. New York: United } \\
\text { Nations. Available on-line at } \\
\text { http://www.un.org/esa/population/orderi } \\
\text { ng.htm }\end{array}$ \\
\hline $\begin{array}{l}\text { Poverty: National } \\
\text { poverty rates ( } \% \text { of } \\
\text { national population) }\end{array}$ & $\begin{array}{l}\text { National poverty rates is the percentage of a country's } \\
\text { population living below the country's established national } \\
\text { poverty line. Quoted from the Earth Trends portal. }\end{array}$ & $\begin{array}{l}\text { Development Data Group, The World } \\
\text { Bank. 2008. } 2008 \text { World Development } \\
\text { Indicators Online. Washington, DC: The } \\
\text { World Bank. Available at: } \\
\text { http://go.worldbank.org/UOFSM7AQ40. }\end{array}$ \\
\hline
\end{tabular}


Table D-1 (continued)

\begin{tabular}{|c|c|c|}
\hline Metric & Definition & Original Source \\
\hline $\begin{array}{l}\text { Public Health: } \\
\text { Contraceptive } \\
\text { prevalence rate } \\
\text { (percent of married } \\
\text { women age 15-49) }\end{array}$ & $\begin{array}{l}\text { Contraceptive prevalence rate is the percentage of women } \\
\text { aged } 15 \text { to } 49 \text { in a marital or consensual union, who are } \\
\text { currently using contraception. Contraception includes both } \\
\text { modern (sterilization, the Pill, condoms, vaginal barrier } \\
\text { methods, etc.) and traditional (periodic or prolonged } \\
\text { abstinence, withdrawal, etc.) methods. Quoted from the Earth } \\
\text { Trends portal. }\end{array}$ & $\begin{array}{l}\text { Department of Economic and Social } \\
\text { Affairs, United Nations Population Division } \\
\text { (UNPD). 2005. World Contraceptive Use. } \\
\text { New York: UNPD. Available on-line at: } \\
\text { http://www.un.org/esa/population/public } \\
\text { ations/contraceptive2005/WCU2005.htm. }\end{array}$ \\
\hline $\begin{array}{l}\text { Public Health: Per } \\
\text { capita total } \\
\text { expenditure on health } \\
\text { (international dollars } \\
\text { per person) }\end{array}$ & $\begin{array}{l}\text { Per capita total expenditure on health is the sum of general } \\
\text { government (public) expenditures on health and private } \\
\text { expenditures on health expressed on a per-person basis. } \\
\text { Annual values are provided in international dollars, calculated } \\
\text { using estimates of local currency purchasing power parity } \\
\text { (PPP) compared to United States (US) dollars. The } \\
\text { international dollar measure minimizes the consequences of } \\
\text { differing price levels between countries; in theory one } \\
\text { international dollar can purchase an equivalent amount of } \\
\text { goods and services in any country. Quoted from the Earth } \\
\text { Trends portal. }\end{array}$ & $\begin{array}{l}\text { World Health Organization (WHO). } 2006 . \\
\text { World Health Report 2006: Annex Table } 3 . \\
\text { Geneva: WHO. Available online at: } \\
\text { http://www.who.int/whr/2006/annex/en/ } \\
\text { index.html and in the WHO Statistical } \\
\text { Information System (WHOSIS): Core } \\
\text { Health Indicators. }\end{array}$ \\
\hline $\begin{array}{l}\text { Public Health: Solid } \\
\text { fuel use (\%) }\end{array}$ & $\begin{array}{l}\text { Solid fuel use measures the percentage of the total population } \\
\text { that burn solid fuels in their households, primarily for cooking } \\
\text { fuel. Solid fuels include coal or biomass fuels such as wood, } \\
\text { charcoal, agricultural residues, and animal dung. }\end{array}$ & $\begin{array}{l}\text { World Health Organization (WHO). } 2006 . \\
\text { Global Health Atlas: World Health } \\
\text { Statistics. Geneva: WHO. Available on-line } \\
\text { at: http://www.who.int/GlobalAtlas/. }\end{array}$ \\
\hline
\end{tabular}


Table D-1 (continued)

\begin{tabular}{|c|c|c|}
\hline Metric & Definition & Original Source \\
\hline $\begin{array}{l}\text { Religious } \\
\text { Fractionalization } \\
\text { Index } \\
\text { (fractionalization } \\
\text { score: higher means } \\
\text { more diverse) }\end{array}$ & $\begin{array}{l}\text { Fractionalization is "a measure of diversity among individuals" } \\
\text { (Bossert, et al., 2006) }\end{array}$ & $\begin{array}{l}\text { Alesina, Alberto, et al, 2003. " } \\
\text { Fractionalization," Journal of Economic } \\
\text { Growth, Springer, vol. 8(2), pages 155-94, } \\
\text { June. }\end{array}$ \\
\hline $\begin{array}{l}\text { Religious freedom } \\
\text { index (Units: } 1- \\
\text { 3=Free; } 4-5=\text { Partly } \\
\text { free; 6-7=Not free) }\end{array}$ & $\begin{array}{l}\text { Religious Freedom is defined by the Center for Religious } \\
\text { Freedom as freedom from "persecution where the focus or } \\
\text { the grounds are themselves religious - where a person's } \\
\text { religion is a component of the persecution or discrimination } \\
\text { they suffer". An example of religious discrimination is a school } \\
\text { that bans Islamic dress. This institutionalized ban would } \\
\text { infringe on the Muslim students' right to live according to their } \\
\text { religion. Quoted from the Earth Trends portal. }\end{array}$ & $\begin{array}{l}\text { Freedom House, Center for Religious } \\
\text { Freedom. 2000. Religious Freedom in the } \\
\text { World: A Global Survey of Religious } \\
\text { Freedom and Persecution. Available on- } \\
\text { line at: } \\
\text { http://www.freedomhouse.org/religion/p } \\
\text { ublications/rfiw/fig1.htm. Washington: } \\
\text { Freedom House. }\end{array}$ \\
\hline $\begin{array}{l}\text { Research and } \\
\text { Development } \\
\text { expenditure (\% of } \\
\text { GDP) }\end{array}$ & Research and Development expenditure as a \% of GDP & $\begin{array}{l}\text { World Bank. 2007b. World Development } \\
\text { Indicators 2007. CD-ROM. Washington, } \\
\text { D.C.; aggregates calculated for HDRO by } \\
\text { the World Bank. }\end{array}$ \\
\hline $\begin{array}{l}\text { Suspended solids per } \\
\text { liter water (mg.) }\end{array}$ & $\begin{array}{l}\text { "A measure of water quality and turbidity." Quoted from the } \\
\text { SEDAC Data Dictionary. }\end{array}$ & $\begin{array}{l}\text { Socioeconomic Data and Applications } \\
\text { Center (SEDAC), Center for International } \\
\text { Earth Science Information Network } \\
\text { (CIESIN), Columbia University }\end{array}$ \\
\hline
\end{tabular}


Table D-1 (continued)

\begin{tabular}{|l|l|l|}
\hline \multicolumn{1}{|c|}{ Metric } & \multicolumn{1}{c|}{ Definition } & \multicolumn{1}{c|}{ Original Source } \\
\hline $\begin{array}{l}\text { Total external debt } \\
\text { (current US\$ per } \\
\text { person) }\end{array}$ & $\begin{array}{l}\text { Total external debt is debt owed to nonresidents of a country } \\
\text { repayable in foreign currency, goods, or services. It is the sum } \\
\text { of public, publicly guaranteed, and private nonguaranteed } \\
\text { long-term debt, use of International Monetary Fund (IMF) } \\
\text { credit, and short-term debt. Short-term debt includes all debt } \\
\text { having an original maturity of one year or less and interest in } \\
\text { arrears on long-term debt. Long-term debt includes all debt } \\
\text { having a maturity of more than one year. Data are in million } \\
\text { current U.S. dollars. Quoted from the Earth Trends portal. }\end{array}$ & $\begin{array}{l}\text { Bevelopment Data Group, The World } \\
\text { Bank. 2008. 2008 World Development } \\
\text { Indicators Online. Washington, DC: The } \\
\text { World Bank. Available at: } \\
\text { http:/go.worldbank.org/U0FSM7AQ40. }\end{array}$ \\
\hline $\begin{array}{l}\text { Total fertility Rate } \\
\text { (average number of } \\
\text { births per woman } \\
\text { based on current age- } \\
\text { specific fertility rates) }\end{array}$ & $\begin{array}{l}\text { "Fertility contributes significantly to population growth, and } \\
\text { thus to pressures on natural resources." Quoted from the } \\
\text { SEDAC Data Dictionary. }\end{array}$ & $\begin{array}{l}\text { Population Reference Bureau (PRB), 2004 } \\
\text { World Population Data Sheet }\end{array}$ \\
\hline
\end{tabular}


Table D-1 (continued)

\begin{tabular}{|c|c|c|}
\hline Metric & Definition & Original Source \\
\hline $\begin{array}{l}\text { Trade in Forest } \\
\text { Products: Imports, } \\
\text { value (US dollars per } \\
\text { person) }\end{array}$ & $\begin{array}{l}\text { Forest products imports show the value, in thousands of U.S. } \\
\text { dollars, of all forest products transfered into a particular } \\
\text { country or region to be sold. Forest products include industrial } \\
\text { roundwood (including sawlogs and veneer logs, pulpwood and } \\
\text { particles, chips and particles, wood residues, and other } \\
\text { industrial roundwood), fuelwood and charcoal, sawnwood, } \\
\text { wood-based panels (including veneer sheets, plywood, particle } \\
\text { board, and fibreboard), wood pulp (including mechanical, } \\
\text { chemical, semi-chemical, dissolving, and recovered paper), } \\
\text { and paper and paperboard (including newsprint, printing and } \\
\text { writing paper, and other paper and paperboard). Both non- } \\
\text { coniferous and coniferous species are included. Quoted from } \\
\text { the Earth Trends portal. This metric was originally published } \\
\text { as an absolute number, and was transformed into a per capita } \\
\text { figure using the countries' total population. }\end{array}$ & $\begin{array}{l}\text { Food and Agriculture Organization of the } \\
\text { United Nations (FAO). 2008. FAOSTAT } \\
\text { Online Statistical Service. Rome: FAO. } \\
\text { Available online at: http://faostat.fao.org/. }\end{array}$ \\
\hline $\begin{array}{l}\text { Transportation: Motor } \\
\text { gasoline consumption } \\
\text { per capita (Liters per } \\
\text { person) }\end{array}$ & $\begin{array}{l}\text { Motor gasoline consumption per capita measures the average } \\
\text { volume of motor gasoline consumed by a specified country per } \\
\text { person for use in the transportation sector. Quoted from the } \\
\text { Earth Trends portal. }\end{array}$ & $\begin{array}{l}\text { International Energy Agency (IEA) } \\
\text { Statistics Division. } 2006 \text {. Energy Balances } \\
\text { of OECD Countries (2008 edition)-- } \\
\text { Extended Balances and Energy Balances of } \\
\text { Non-OECD Countries ( } 2007 \text { edition)-- } \\
\text { Extended Balances. Paris: IEA. Available at } \\
\text { http://data.iea.org/ieastore/default.asp. }\end{array}$ \\
\hline
\end{tabular}


Table D-1 (continued)

\begin{tabular}{|c|c|c|}
\hline Metric & Definition & Original Source \\
\hline $\begin{array}{l}\text { Transportation: } \\
\text { Passenger cars per } \\
1000 \text { people }\end{array}$ & $\begin{array}{l}\text { Passenger cars per } 1000 \text { people refers to road motor vehicles } \\
\text { intended for the carriage of passengers and designed to seat } \\
\text { no more than nine people (including the driver) per } 1000 \\
\text { members of a country's population. These numbers exclude } \\
\text { buses, freight vehicles, and two-wheelers such as mopeds and } \\
\text { motorcycles. Quoted from the Earth Trends portal. }\end{array}$ & $\begin{array}{l}\text { Development Data Group, The World } \\
\text { Bank. 2006. } 2006 \text { World Development } \\
\text { Indicators Online. Washington, DC: The } \\
\text { World Bank. Available at: } \\
\text { http://publications.worldbank.org/ecomm } \\
\text { erce/catalog/product?item_id=631625. }\end{array}$ \\
\hline $\begin{array}{l}\text { Transportation: Pump } \\
\text { prices for diesel fuel } \\
\text { (US dollars per liter) }\end{array}$ & $\begin{array}{l}\text { This variable refers to the pump prices of the most widely sold } \\
\text { grade of diesel fuel in a given country. Prices have been } \\
\text { converted from the local currency to U.S. Dollars. Quoted from } \\
\text { the Earth Trends portal. }\end{array}$ & $\begin{array}{l}\text { The World Bank. 2004. World } \\
\text { Development Indicators } 2004 \text { (see } \\
\text { http://publications.worldbank.org/ecomm } \\
\text { erce/catalog/product?item_id=990561) } \\
\text { (The World Bank, Washington, D.C.) }\end{array}$ \\
\hline $\begin{array}{l}\text { Transportation: } \\
\text { Volume of public road } \\
\text { transport (passenger- } \\
\text { km per person) }\end{array}$ & $\begin{array}{l}\text { Volume of Public Transport (Road) measures the usage of a } \\
\text { city's road-based public transport modes (i.e. buses, } \\
\text { microbuses, and taxis) throughout a single year, measured in } \\
\text { million passenger-kilometers. The data are calculated by } \\
\text { multiplying the number of passengers by the number of } \\
\text { kilometers they travel per year. Quoted from the Earth Trends } \\
\text { portal.. }\end{array}$ & $\begin{array}{l}\text { International Road Federation (IRF). } 2002 . \\
\text { World Road Statistics } 2002 \text { on CD-ROM, } \\
\text { Table 5B (available on-line } \\
\text { at:http://www.irfnet.org/wrs.asp). } \\
\text { Geneva: International Road Federation. }\end{array}$ \\
\hline $\begin{array}{l}\text { Urban and Rural } \\
\text { Areas: Growth rate of } \\
\text { rural population (\%) }\end{array}$ & $\begin{array}{l}\text { Growth rate of rural population is the average annual rate of } \\
\text { change of the midyear population in areas defined as rural. } \\
\text { This dataset contains estimates from } 1950 \text { to } 2030 \text { in five year } \\
\text { intervals. For } 2010 \text { to 2030, all data are forecasts based on } \\
\text { assumptions enumerated in the technical notes. Data are } \\
\text { available for most countries. Quoted from the Earth Trends } \\
\text { portal. }\end{array}$ & $\begin{array}{l}\text { United Nations, Department of Economic } \\
\text { and Social Affairs, Population Division. } \\
\text { 2006. World Urbanization Prospects: The } \\
2005 \text { Revision. Urban and Rural Areas } \\
\text { Dataset (POP/DB/WUP/Rev.2005/1/Table } \\
\text { A.3), dataset in digital form. Available on- } \\
\text { line at http://esa.un.org/unup/. New } \\
\text { York: United Nations. }\end{array}$ \\
\hline
\end{tabular}


Table D-1 (continued)

\begin{tabular}{|l|l|l|}
\hline \multicolumn{1}{|c|}{ Metric } & \multicolumn{1}{|c|}{ Definition } & \multicolumn{1}{c|}{ Original Source } \\
\hline $\begin{array}{l}\text { Urban and Rural } \\
\text { Areas: Total } \\
\text { population in cities } \\
\text { with more than } \\
\begin{array}{l}100,000 \text { inhabitants } \\
\text { (\% of population in } \\
2000)\end{array}\end{array}$ & $\begin{array}{l}\text { Total population in cities with more than 100,000 inhabitants } \\
\text { refers to the number of people living in cities that have a } \\
\text { population greater than 100,000. Quoted from the Earth } \\
\text { Trends portal. }\end{array}$ & $\begin{array}{l}\text { The World Bank Group. 2004. Urban } \\
\text { Population in World Bank Regions by City } \\
\text { Size. Available on-line at: } \\
\text { http://www.worldbank.org/urban/env/po } \\
\text { pulation-regions.htm. Washington, DC: } \\
\text { World Bank. }\end{array}$ \\
\hline $\begin{array}{l}\text { Urban and Rural } \\
\text { Areas: Urban } \\
\text { population as a } \\
\text { percent of total } \\
\text { population (\%) }\end{array}$ & $\begin{array}{l}\text { Urban Population as a Percent of Total Population is the } \\
\text { proportion of a country's total national population that resides } \\
\text { in urban areas. Any person not residing in an area classified as } \\
\text { urban is counted in the rural population. Definitions of urban } \\
\text { populations vary slightly from country to country. Quoted } \\
\text { from the Earth Trends portal. }\end{array}$ & $\begin{array}{l}\text { United Nations, Department of Economic } \\
\text { and Social Affairs, Population Division. } \\
\text { 2006. World Urbanization Prospects: The } \\
\text { 2005 Revision. Urban and Rural Areas } \\
\text { Dataset (POP/DB/WUP/Rev.2005/1/Table } \\
\text { A.2), dataset in digital form. Available on- } \\
\text { line at http://esa.un.org/unup/. New } \\
\text { York: United Nations. }\end{array}$ \\
\hline $\begin{array}{l}\text { Urban population } \\
\text { weighted TSP } \\
\text { concentration } \\
\text { (micrograms TSP per } \\
m^{3} \text { ) }\end{array}$ & $\begin{array}{l}\text { Poor ambient air quality affects both human and ecosystem } \\
\text { health. Many studies have linked exposure to particulate } \\
\text { matter (PM) to adverse health effects in humans such as } \\
\text { increased asthma attacks, chronic bronchitis, decreased lung } \\
\text { function, and premature death. PM can travel over long } \\
\text { distances and is a significant contributor to reduced visibility. } \\
\text { The deposition of PM can change the nutrient composition of } \\
\text { soils and surface waters and affects the diversity of } \\
\text { ecosystems. Quoted from the SEDAC Data Dictionary. }\end{array}$ & $\begin{array}{l}\text { Socioeconomic Data and Applications } \\
\text { Center (SEDAC), Center for International } \\
\text { (CIESIN), Columbia University }\end{array}$ \\
\end{tabular}




\section{Appendix E: A Brief History of the Concentric Circles Approach to Sustainable Development}

By Andrés Tarté

I credit my father, a brilliant scientist, and arguably the foremost expert in matters of sustainability in my home country of Panama, for my exposure at an early age to the idea of sustainable development. An illustration of the so-called 'triple bottom-line' - an integration of the environmental, social, and economic dimensions of development - is probably the easiest way to get someone to understand the concept. It is usually illustrated using three distinct circles, one for each dimension, that share some parts of their area with each other, like this:

Figure E-1: The Dimensions of Sustainable Development - Classic Illustration Approach

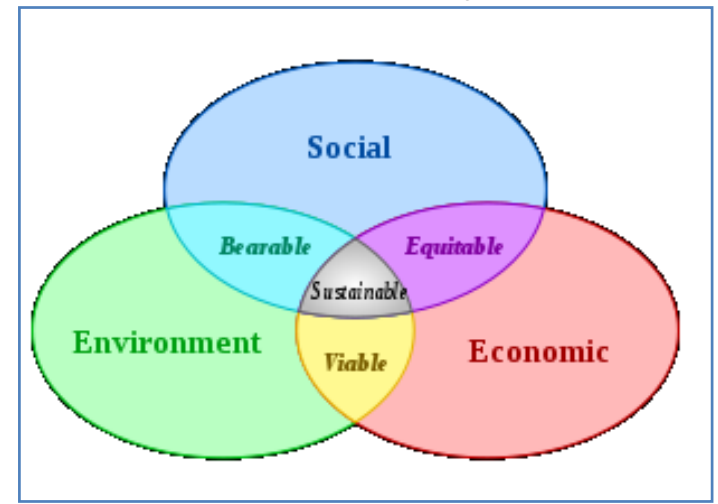

Source: IUCN, 2006.

The very small area in the middle that all three circles have in common represents sustainable development. However, my father was never satisfied with this illustrative approach. The illustration implies that there is room for development outside the 'sustainable' area, which if you think about it, is impossible: if it's not sustainable, it cannot be called development; sooner or later, it will mean destruction.

So a few years ago he conceived a different approach, one that he thought would be more in tune to the planet's reality. This would be the concentric circles approach, which he consequently included in his 2006 book, Picnic con Hormigas ${ }^{36}$. It looks like this:

\footnotetext{
${ }^{36}$ Tarté, Rodrigo. 2006. Picnic con Hormigas: Reflexiones sobre Gestión del Conocimiento y Desarrollo (Sostenible). Ciudad del Saber, Panama.
} 
Figure E-2: The Dimensions of Sustainable Development - the Concentric Circles Approach

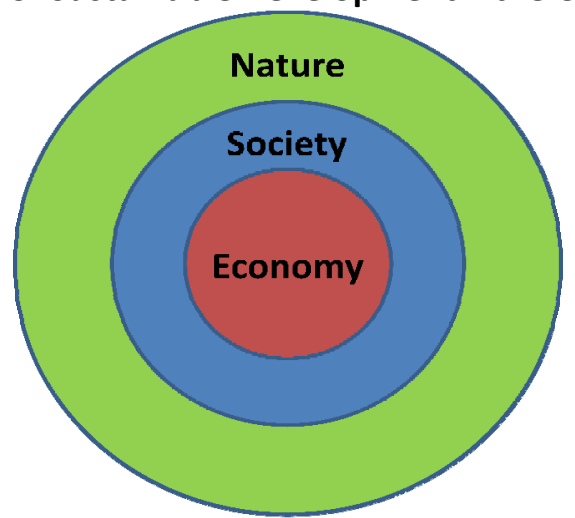

Source: Adapted from Tarté, 2006.

Three circles, one within the other: economic activity within the boundaries of society, and society within the boundaries of the natural environment. So simple, so obvious, and yet, no one else had come up with it, or so we thought at the time. I certainly had not seen anything like it before, and neither had he.

A few years later, I decided to do some detective work and try to find out if my father had indeed invented this new illustrative approach. After conducting an extensive search on the World Wide Web, we were able to put the matter to rest. Here's what I was able to find:

The earliest evidence of this approach references a book from 1995:

- K. Peattie, Environmental marketing management. Meeting the green challenge, Financial Times. Pitman Publishing, London (1995).

The book itself is not online, nor in my school's library, so I was not able to check it out and see what the graph looks like in it. But it is credited by a 2006 article (Lozano, Envisioning Sustainability Three-Dimensionally), as the source of the following drawing:

Figure E-3: The Concentric Circles Approach Taken from Lozano, 2006

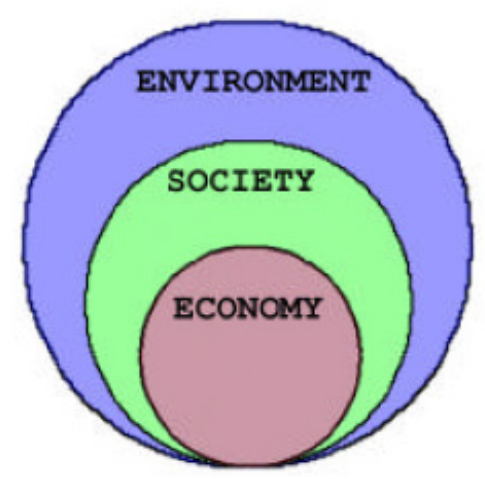

Source: Lozano, 2006. 
The article also credits two other sources for the drawing, but Peattie's is the earliest. The first of these two other sources is:

- Mebratu, D. 1996. Sustainability as a Scientific Paradigm. Lund: International Institute for Industrial Environmental Economics.

This time I was able to view the source and copy the illustration that appears in it:

Figure E-4: The Concentric Circles Approach Taken from Mebratu, 1996

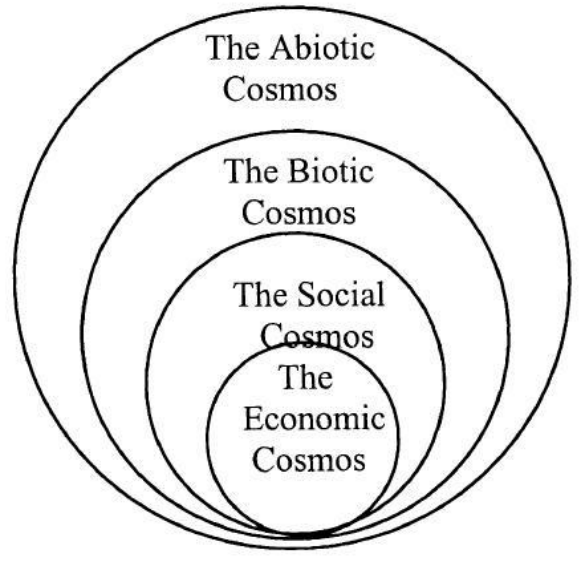

Source: Mebratu, 1996.

Note that the outer circle takes things one step further, although I think it implies that there is no life outside our planet...

The third source credited by Lozano is Maureen Hart. She is by far the source that gets more credit for the approach, referenced in the great majority of websites that include the drawing (and copy it directly from her website, http://www.sustainablemeasures.com):

Figure E-5: The Concentric Circles Approach Taken from Hart, 1998

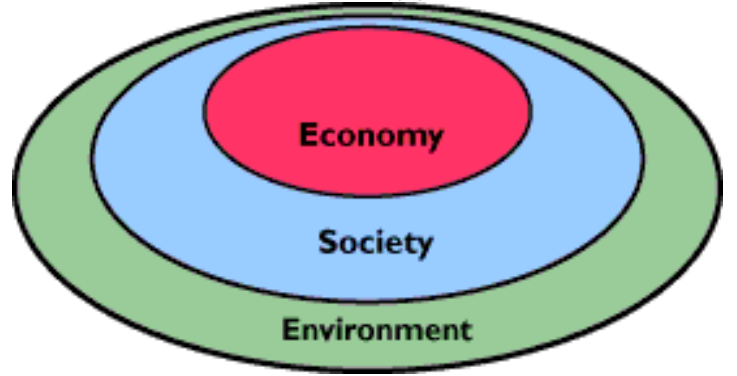

Source: Hart, 1998.

The earliest reference made to her mentions this source from 1998 : 
- Hart, Maureen, Sustainable Community Indicators Trainers' Workshop, Hart Environmental Data.

http://www.sustainablemeasures.com/Training/Indicators/Circle3.html

Now, this is an internet source that says 'copyright 1998' at the bottom, so it is possible that the site was created in 1998, but the graph added later on. However, there is no doubt that by 1999, Hart had already published the illustration, because this other publication gives her credit:

- Meter, Ken. The Neighborhood Sustainability Indicators Guidebook. Crossroads Resource Center, 1999 (available online at: http://www.crcworks.org/guide.pdf).

On that publication, the drawing has been slightly modified and appears like this (the shaded area has been named by Meter as the 'sustainability zone'):

Figure E-6: The Concentric Circles Approach Taken from Meter, 1999

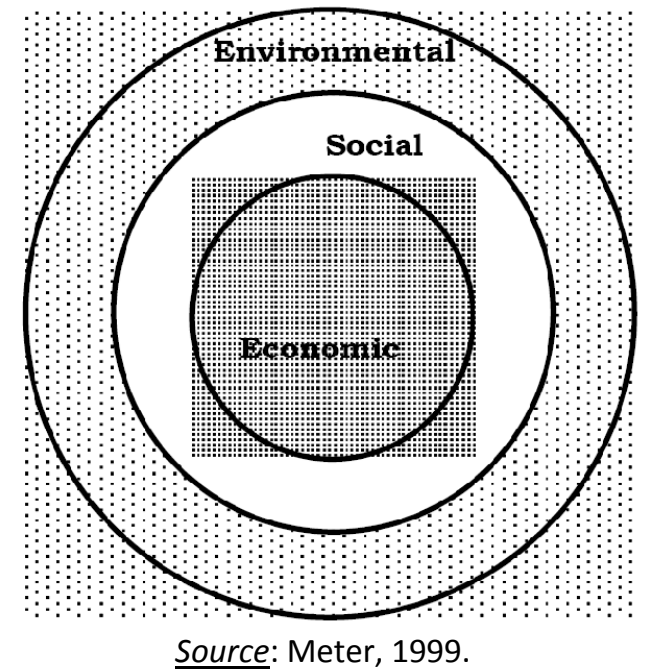

Finally, an online course module on Strategic Environmental Assessment developed by the United Nations University mentions the concentric circles concept (http://sea.unu.edu/course/?page_id=50), and credits this source:

- Levett, R. (1997) "Indicators for a Civilised City", contribution to ERIC seminar, London, 7 October.

This source would come before Hart (1998), but after Peattie (1995) and Mebratu (1996).

So, to sum up, there's evidence of at least six occurrences (including my father) where the basic same approach arose spontaneously in different places, and at different times. I guess that makes it even more valid...

August, 2009. 


\section{Appendix F: Table of Critical Values for Pearson's R}

Table F-1 lists the critical values for Pearson's $\mathrm{R}$ based on their corresponding alpha level, $\mathrm{P}\left(\mathrm{H}_{0}\right)$, and number of samples $(n)$ - in this case, the number of countries tested for correlation between a given metric and proximity/movement relative to the Quadrant.

Table F-1: Table of Critical Values for Pearson's R

Source:

http://faculty.fortlewis.edu/CHEW_B/Documents/Table\%20o

f\%20critical\%20values\%20for\%20Pearson\%20correlation.htm

\begin{tabular}{|c|c|c|c|c|}
\hline $\begin{array}{r}\text { Alpha } \\
\text { level }\end{array}$ & 0.100 & 0.050 & 0.010 & 0.001 \\
\hline $\mathbf{n}$ & \multicolumn{4}{|c|}{ Critical values for Pearson's $\mathbf{R}$} \\
\hline 4 & 0.900 & 0.950 & 0.990 & 0.999 \\
\hline 5 & 0.805 & 0.878 & 0.959 & 0.991 \\
\hline 6 & 0.729 & 0.811 & 0.917 & 0.974 \\
\hline 7 & 0.669 & 0.754 & 0.875 & 0.951 \\
\hline 8 & 0.621 & 0.707 & 0.834 & 0.925 \\
\hline 9 & 0.582 & 0.666 & 0.798 & 0.898 \\
\hline 10 & 0.549 & 0.632 & 0.765 & 0.872 \\
\hline 11 & 0.521 & 0.602 & 0.735 & 0.847 \\
\hline 12 & 0.497 & 0.576 & 0.708 & 0.823 \\
\hline 13 & 0.476 & 0.553 & 0.684 & 0.801 \\
\hline 14 & 0.458 & 0.532 & 0.661 & 0.780 \\
\hline 15 & 0.441 & 0.514 & 0.641 & 0.760 \\
\hline 16 & 0.426 & 0.497 & 0.623 & 0.742 \\
\hline 17 & 0.412 & 0.482 & 0.606 & 0.725 \\
\hline 18 & 0.400 & 0.468 & 0.590 & 0.708 \\
\hline 19 & 0.389 & 0.456 & 0.575 & 0.693 \\
\hline 20 & 0.378 & 0.444 & 0.561 & 0.679 \\
\hline 21 & 0.369 & 0.433 & 0.549 & 0.665 \\
\hline 22 & 0.360 & 0.423 & 0.537 & 0.652 \\
\hline 23 & 0.352 & 0.413 & 0.526 & 0.640 \\
\hline 24 & 0.344 & 0.404 & 0.515 & 0.629 \\
\hline 25 & 0.337 & 0.396 & 0.505 & 0.618 \\
\hline 26 & 0.330 & 0.388 & 0.496 & 0.607 \\
\hline 27 & 0.323 & 0.381 & 0.487 & 0.597 \\
\hline 28 & 0.317 & 0.374 & 0.479 & 0.588 \\
\hline 29 & 0.311 & 0.367 & 0.471 & 0.579 \\
\hline 30 & 0.306 & 0.361 & 0.463 & 0.570 \\
\hline
\end{tabular}


Table F-1 (continued)

\begin{tabular}{|l|c|c|c|c|}
\hline $\begin{array}{c}\text { Alpha } \\
\text { level }\end{array}$ & $\mathbf{0 . 1 0 0}$ & $\mathbf{0 . 0 5 0}$ & $\mathbf{0 . 0 1 0}$ & $\mathbf{0 . 0 0 1}$ \\
\hline $\mathbf{n}$ & \multicolumn{4}{|c|}{ Critical values for Pearson's R } \\
\hline 35 & 0.283 & 0.334 & 0.430 & 0.532 \\
\hline 40 & 0.264 & 0.312 & 0.403 & 0.501 \\
\hline 45 & 0.248 & 0.294 & 0.380 & 0.474 \\
\hline 50 & 0.235 & 0.279 & 0.361 & 0.451 \\
\hline 60 & 0.214 & 0.254 & 0.330 & 0.414 \\
\hline 70 & 0.198 & 0.235 & 0.306 & 0.385 \\
\hline 80 & 0.185 & 0.220 & 0.286 & 0.361 \\
\hline 90 & 0.174 & 0.207 & 0.270 & 0.341 \\
\hline 100 & 0.165 & 0.197 & 0.256 & 0.324 \\
\hline 200 & 0.117 & 0.139 & 0.182 & 0.231 \\
\hline 300 & 0.095 & 0.113 & 0.149 & 0.189 \\
\hline 400 & 0.082 & 0.098 & 0.129 & 0.164 \\
\hline 500 & 0.074 & 0.088 & 0.115 & 0.147 \\
\hline 1000 & 0.052 & 0.062 & 0.081 & 0.104 \\
\hline
\end{tabular}

